\author{
UNIVERSIDADE DE SÃO PAULO \\ INSTITUTO DE ESTUDOS BRASILEIROS \\ PROGRAMA DE PÓS- GRADUAÇÃO \\ CULTURAS E IDENTIDADES BRASILEIRAS
}

MARIA APARECIDA VIANA SCHTINE PEREIRA

mariaviana8@uol.com.br

\title{
O Coruja, de Aluísio Azevedo: romance de formação sob o prisma do grotesco.
}

\author{
VERSÃO CORRIGIDA \\ O EXEMPLAR ORIGINAL ENCONTRA-SE DISPONÍVEL NA BIBLIOTECA DO \\ INSTITUTO DE ESTUDOS BRASILEIROS (IEB-USP)
}

SÃO PAULO 


\author{
UNIVERSIDADE DE SÃO PAULO \\ INSTITUTO DE ESTUDOS BRASILEIROS \\ PROGRAMA DE PÓS- GRADUAÇÃO \\ CULTURAS E IDENTIDADES BRASILEIRAS
}

\title{
O Coruja, de Aluísio Azevedo: romance de formação sob o prisma do grotesco.
}

\author{
MARIA APARECIDA VIANA SCHTINE PEREIRA \\ Dissertação apresentada ao Programa de Pós- \\ Graduação Culturas e Identidades Brasileiras do \\ Instituto de Estudos Brasileiros da Universidade de \\ São Paulo, para obtenção do título de Mestre em \\ Filosofia. \\ Área de concentração: Estudos Brasileiros \\ Orientador: Prof. Dr. Fernando Augusto Magalhães \\ Paixão
}

São Paulo 
Em memória do meu pai, José Severiano Pereira, com quem pouco convivi e tanto aprendi. 


\section{Meus sinceros agradecimentos}

Ao Prof. Dr. Fernando Augusto Magalhães Paixão, pela confiança depositada, pela orientação segura e pela presença sempre incentivadora, que muito contribuíram para o meu crescimento intelectual durante este percurso formativo.

Ao Prof. Dr. Marcos Antonio de Moraes, pelas valiosas sugestões e críticas durante a qualificação, que me deram segurança para alicerçar as ideias defendidas neste estudo, e pela lúcida interlocução durante a defesa.

Ao Prof. Marcus Vinicius Mazzari, pelos estudos pioneiros sobre o romance de formação, que muito contribuíram para a fundamentação das ideias aqui defendidas e com quem tive o prazer de dialogar durante a defesa desta dissertação.

Ao Prof. Dr. Hélio Seixas Guimarães, pelas valiosas sugestões e críticas durante o exame de qualificação.

À Prof. ${ }^{a}$ Dr. ${ }^{a}$ Marisa Midori Deaecto, que acompanhou esta pesquisa desde que era embrião e, com suas leituras e amizade sincera, ajudou-me a tornar real um sonho antigo.

Ao Prof. Dr. Álvaro Faleiros, pelas contribuições durante o curso "A pesquisa em literatura: perspectivas francesas”, do programa de Pós-Graduação da FFLCH.

Ao Prof. Dr. Joaquim Aguiar, pelas discussões fecundas durante os cursos realizados na graduação e na pós-graduação e pelas contribuições dadas quando da leitura da primeira versão do projeto de pesquisa.

Ao Prof. Dr. Ivan Teixeira (in memoriam), que, com a generosidade dos verdadeiros mestres, garantiu-me que eu não só havia escolhido para estudo um grande romancista, mas um romance de "envergadura".

Ao amigo Danilo Morales, que acompanhou meus primeiros passos no percurso editorial e agora faz o mesmo nesse novo caminho, com valorosas indicações de leitura e conversas incentivadoras.

À Elizabeth Sfrizo, Nair Hitomi Kayo e ao Agnaldo Alves, pelas prestimosas leituras e observações e à Amanda Valentin, pela ajuda na padronização. 
Aos colegas da Pós-Graduação Raquel Endalécio, Ana Luisa Dutra e Sílvio D'onofrio, pelas trocas sempre significativas, e à Patrícia Pereira, por ter me estimulado a participar de evento acadêmico, onde pude discutir questões aqui tratadas.

À Cristina Pires, que acompanhou este percurso, desde a inscrição do projeto até o depósito da dissertação, com sua dedicação peculiar, dispensada a todos nós, alunos do IEB.

Aos amigos e às amigas que sempre foram suporte afetivo indispensável ao longo da vida. Mas neste momento formativo agradeço especialmente a Daniela Padilha, Rosinha, Adalberto Santos, Vitória Líbia Barreto, Maria Lúcia Brenéli, Edy Lima, Eloísa Aragão, Flamarion Maués, Ivan Marques, Mário Matsukura, Neide Takahashi, Celso Kenji, Sandro Lourenço e Ricardo Costa.

À minha família, que, apesar da distância, está sempre presente, sobretudo por compreender os motivos das minhas necessárias ausências durante este período. 


\section{RESUMO}

O Coruja, de Aluísio Azevedo: romance de formação sob o prisma do grotesco.

O termo Bildungsroman foi empregado pela primeira vez associado ao romance de Goethe, Os anos de aprendizado de Wilhelm Meister (1795-1796). Desde então, tornouse uma linhagem literária de longa permanência na literatura. $\mathrm{Na}$ produção dos escritores brasileiros do século XIX, diferentemente do que ocorreu nos países europeus, o romance de formação não encontrou ressonância. Todavia, a obra $O$ Coruja, de Aluísio Azevedo, alinha-se em tal categoria, e de forma muito particular. É o que pretende defender a presente dissertação, ao procurar entender a composição do texto e das personagens à luz do grotesco e da tradição deformante que essa perspectiva oferece. No percurso de análise, são utilizados conceitos de Mikhail Bakhtin, George Lukács e Marcus Mazzari, entre outros, com o intuito de verificar em que medida a história de André e Teobaldo pode ser lida como "um romance de formação às avessas", expressão última do meio social em que se desenvolve.

Palavras-chave: Aluísio Azevedo, Literatura brasileira, grotesco, História do Brasil, crítica literária. 


\section{ABSTRACT}

\section{Aluísio Azevedo's $O$ Coruja: a formation novel under the prism of grotesque.}

The first time the term Bildungsroman was used it was connected to Goethe's novel, Wilhelm Meister's Apprenticeship (1795-1796). Since then, it has become a lasting literary lineage. Differently from what happened in European countries, the formation novel has not found resonance in the works of $19^{\text {th }}$ century Brazilian writers. The novel O Coruja (The $O w l$ ) by Aluísio Azevedo, falls into that category, although in a peculiar fashion. Stating such an argument is the main task this dissertation tries to undertake, by means of capturing the text and character's composition through the lens of the grotesque, and of the deforming tradition perspective thus associated. Throughout the analysis we shall draw on concepts of Mikhail Bakhtin, George Lukács, and Marcus Mazzari in order to ascertain in what measure the story of André and Teobaldo can be read as a "reverse formation novel", ultimate expression of the social framing within which it takes place.

Keywords: Aluísio Azevedo, Brazilian literature, grotesque, Brazilian history, literary criticism. 


\section{Introdução}

\section{Capítulo 1 - Um escritor em sintonia com seu tempo}

1.1. Os primeiros anos em São Luís do Maranhão ...................................... 7

1.2. A primeira estada no Rio de Janeiro ................................................. 10

1.3. De volta ao Maranhão.............................................................................. 17

1.4. A consagração como romancista ......................................................... 21

1.5. O desafio de viver da própria pena .................................................. 25

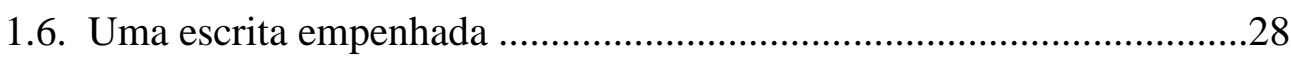

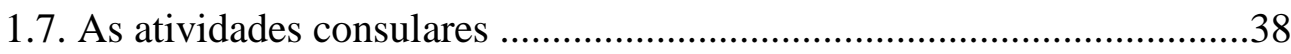

\section{Capítulo 2 - O Coruja: da produção à recepção}

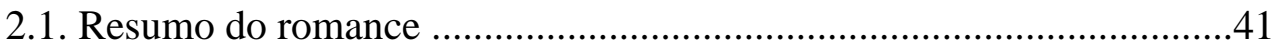

2.2. A suposta gênese do romance..........................................................47

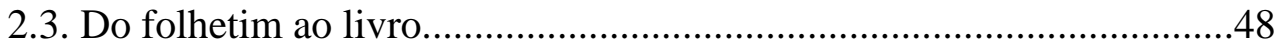

2.4. Alguns dados sobre as edições..........................................................52

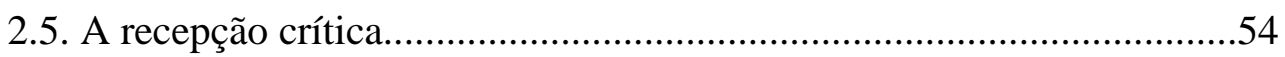

\section{Capítulo 3 - A leitura d' $O$ Coruja como um romance de formação}

3.1. Alguns apontamentos sobre o romance de formação.............................70

3.2. O romance de formação no "momento pós-goethiano"..........................74

3.3. O processo formativo de André e Teobaldo........................................77

3.4. O processo formativo de Inês e Branca............................................... 89

3.5. A educação sentimental de André e Teobaldo....................................92

3.6. O Coruja e L'éducation sentimentale, uma aproximação.................. 99

\section{Capítulo 4 - Figurações do grotesco na composição do romance}

4.1. A evolução do grotesco como categoria estética................................104

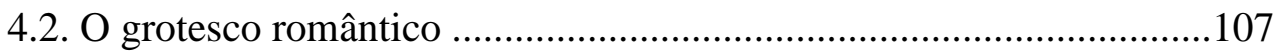

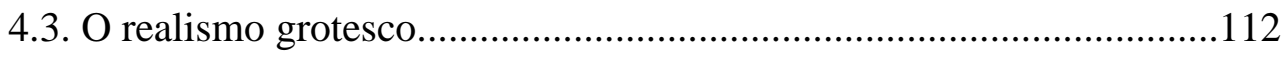

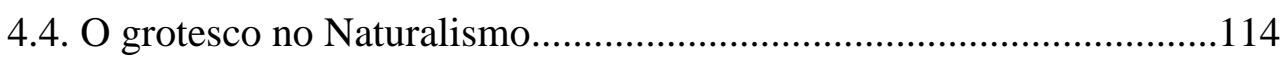

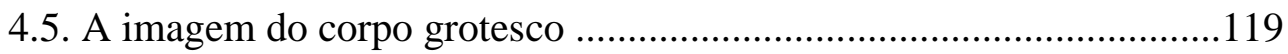


4.6. O animalesco na configuração das personagens................................124

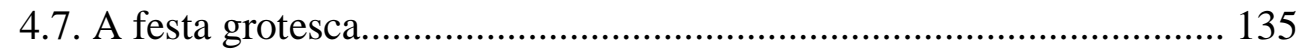

4.8. A crise nervosa deflagradora do choque perceptivo......................... 134

\section{Capítulo 5 - O duplo e o grotesco crítico na composição narrativa}

5.1. Um preâmbulo sobre o duplo............................................................143

5.2. O duplo na construção das personagens centrais do romance ...........146

5.3. O grotesco para configurar uma trajetória formativa às avessas........158

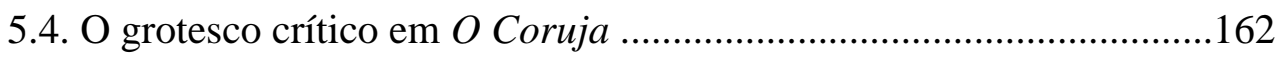

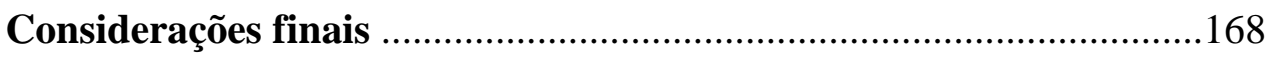

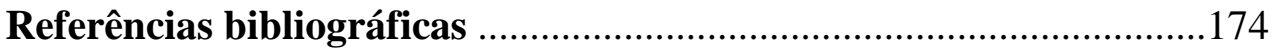

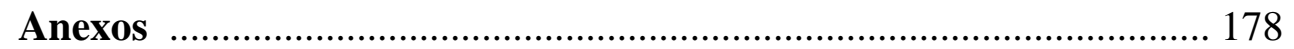




\section{INTRODUÇÃO}

Aluísio Azevedo foi um dos poucos romancistas brasileiros de seu tempo a assumir publicamente que tinha planos de sobreviver exclusivamente do ofício de escritor. Mesmo que para isso tivesse que submeter seus escritos à produção folhetinesca antes de revisá-los para publicação posterior em livros, caso da obra $O$ Coruja, impressa no rodapé do jornal O Paiz, em 1885.

O escritor é conhecido também pelo seu empenho em promover as próprias obras, atitude que o levou a publicar, no periódico A Semana, em 1885, artigo intitulado "Brasileiros antigos e modernos", 1 em que apresentava ousado projeto literário de escrever um ciclo de romances, como feito por Émile Zola, que, sob o título geral Les Rougon-Macquart, produziu uma série de vinte volumes, nos quais retratou a saga de uma família durante o Segundo Império na França. No entanto, esse projeto inicial foi abandonado, e o escritor maranhense salpicou parte de suas ideias nos romances $O$ Coruja, $O$ homem e principalmente em $O$ cortiço.

Em sua tese de doutoramento, que teve por objetivo analisar a produção dos romances folhetinescos de Aluísio Azevedo, Angela Maria Rubel Fanini observa:

O Coruja, a crítica literária não é unânime em condená-lo, pois há vários críticos que o vêem como um caso isolado em nossas letras, considerando-o romance filosófico de altíssimo nível, comparável em temática e formalização aos romances de Fiódor Dostoiévski. Nesse caso, não é tido como "comercial" ou folhetinesco e não é totalmente depreciado. $^{2}$

O fato de a estudiosa considerar $O$ Coruja uma exceção no corpus por ela escolhido reforça nossa hipótese de que a obra, apesar de publicada em folhetim,

\footnotetext{
${ }^{1}$ MAYA, Alcides. Discurso proferido em sessão solene extraordinária do dia 21 de julho de 1914 na Academia Brasileira de Letras. Disponível em: <www.academia.org.br/abl/media/Tomo\%20I\%20$\% 201897 \% 20 \mathrm{a} \% 201919$.pdf $>$. p. 669. Acesso em: jun. de 2012.

${ }^{2}$ Os romances-folhetins de Aluísio Azevedo: Aventuras periféricas. Tese de Doutorado, defendida por Angela Maria Rubel Fanini na Universidade Federal de Santa Catarina em 2003. Ao falar de sinais da leitura de Dostoiévski, a autora refere-se aos estudos de Eugênio Gomes. Esse aspecto será retomado por nós no capítulo 2 .
} 
apresenta características que a aproximam do plano original traçado por Aluísio: criar um grande ciclo de romances em que retrataria aspectos da sociedade de sua época.

Durante nossa leitura do romance, percebemos que aspectos concernentes tanto à formação escolar quanto à educação sentimental de André e Teobaldo, personagens centrais do romance, são recorrentes. $\mathrm{O}$ que nos fez vislumbrar a possibilidade de analisá-lo na perspectiva do romance de formação.

O termo Bildungsroman foi empregado pela primeira vez associado ao romance de Goethe, Os anos de aprendizado de Wilhelm Meister (1795-1796). Desde então, criou-se um signo literário de longa permanência na história da literatura, tendo em vista obras construídas em torno da formação do protagonista. Na literatura brasileira do século XIX, diferentemente do que se pode verificar nos países europeus, o romance de formação não encontrou ressonância. Todavia, acreditamos que a obra $O$ Coruja enquadra-se em tal categoria, ainda que Aluísio Azevedo tenha utilizado elementos do grotesco para escrever um livro de formação bem diferente do paradigma goethiano.

Nosso objetivo, então, é analisar detidamente a obra na tentativa de verificar em que medida ela pode ser lida como um romance de formação, ainda que "às avessas", e de que maneira o escritor utilizou figurações do grotesco para compô-la.

A nosso ver, não é por acaso que a construção do romance de formação no último quartel do século XIX no Brasil foi fadada ao insucesso, por isso, achamos por bem abrir a dissertação com uma nota biográfica de Aluísio Azevedo. Mas como pano de fundo para compreender alguns aspectos sociais e políticos da época em que viveu e escreveu. Alguns desses elementos serão retomados durante a análise do romance.

Portanto, enfatizaremos a participação do escritor em questões como a polêmica em torno da estética romântica e realista, a assumida posição anticlerical e republicana, o engajamento na luta pelo direito autoral no Brasil e a consciência que tinha sobre a dificuldade de viver do seu trabalho como escritor à época.

Por tratar-se de obra pouco estudada, e que não teve muitas edições, abriremos o segundo capítulo com resumo do romance $O$ Coruja. Esse procedimento poderá facilitar também a análise de trechos a ser feita posteriormente. Em seguida, apresentaremos 
informações sobre a possível gênese da obra e a respeito das edições. Por ter sido o romance publicado inicialmente em folhetim, apresentaremos ainda alguns dados sobre o jornal $O$ Paiz em 1885, ano em que $O$ Coruja figurou em seu rodapé.

Segundo Orna Messer,

a crítica mais frequentemente divide a obra de Aluísio Azevedo em duas partes. Uma destinada às folhas matutinas e, portanto, suscetível ao apelo romântico dos consumidores, e outra preparada para edição definitiva, na qual conceitos naturalistas superam os resquícios daqueles ingredientes da prosa pouco atenta à depuração realista. ${ }^{3}$

No caso da obra que escolhemos para estudo, alguns críticos a condenam; outros, apesar dos "deslizes" na construção, consideram suas qualidades e lamentam o fato de ela ter sido escrita ao "correr da pena", para ser publicada em folhetim. Por isso, apesar de escassa, achamos relevante também incluir no segundo capítulo breve explanação sobre a recepção da obra $O$ Coruja pela crítica brasileira, mas apontando algumas questões que aprofundaremos nos capítulos subsequentes.

O terceiro capítulo será iniciado com apresentação de preâmbulo sobre o romance de formação, tendo como base a obra considerada pela crítica como o protótipo por excelência desse subgênero: Os anos de aprendizagem de Wilhelm Meister, de Goethe. Nessa primeira parte, dialogaremos com textos de Georg Lukcás, Mikhail Bakhtin e Marcus Vinicius Mazzari.

Em seguida, apresentaremos análise que nos permite enquadrar o romance $O$ Coruja em tal categoria, ainda que o protótipo goethiano esteja longe de ser seguido. $\mathrm{O}$ tema da educação sentimental das personagens centrais da obra também é analisado nesse momento, em que faremos uma aproximação entre o romance de Aluísio Azevedo e L'éducation sentimentale, de Flaubert. Adotamos esse procedimento metodológico, pois, para nós, fez-se necessário compreender teoricamente o conceito de romance de formação para melhor referendar a análise da obra em estudo.

O mesmo percurso será adotado no quarto capítulo, em que breve explanação

\footnotetext{
${ }^{3}$ LEVIN, Orna Messer (Org.). Aluísio Azevedo romancista. In: Aluísio Azevedo. Ficção Completa, vols. I e II. Rio de Janeiro: Nova Aguilar, 2005, p. 29.
} 
sobre a evolução do grotesco, com ênfase na literatura, antecipará o estudo analítico da presença dessa categoria estética na tessitura do romance. Para tanto, serão revisitados textos canônicos sobre o assunto: Do grotesco e do sublime, de Victor Hugo, $O$ grotesco, de Wolfgang Kayser e a obra Cultura popular na Idade Média e no Renascimento no contexto de François Rabelais, de Mikhail Bakhtin. Dialogaremos também com Muniz Sodré e Raquel Paiva, pois esses estudiosos fazem significativas aproximações com a realidade brasileira.

Percorrido esse caminho, o derradeiro capítulo será dedicado à análise do duplo na construção das personagens centrais do romance e à retomada de elementos do grotesco, como a caricatura e a animalização, para demonstrar em que medida Aluísio Azevedo lançou mão dessa categoria estética para urdir um romance de formação.

Durante essa análise, consideraremos a concepção das personagens, a relação estabelecida entre elas, o vocabulário, a descrição espacial e a condução da narrativa. No entanto, sem perder de vista que nosso objetivo é apontar em que medida essas figurações estéticas podem ter sido usadas pelo escritor para mostrar a formação e a deformação das duas personagens centrais do romance: André e Teobaldo. 


\section{CAPÍTULO 1 - UM ESCRITOR EM SINTONIA COM SEU TEMPO}

\section{1. Os primeiros anos em São Luís do Maranhão}

Aluísio Tancredo Gonçalves de Azevedo nasceu em 14 de abril de 1857, em São Luís do Maranhão. Seus pais, os portugueses David Gonçalves de Azevedo e Emília Amália Pinto de Magalhães, tiveram cinco filhos, dos quais, além de Aluísio, dois outros se enveredaram pelos caminhos literários: Artur Azevedo, conhecido, sobretudo, por seu trabalho como dramaturgo, e Américo Azevedo, que chegou a publicar alguns livros de poesia, mas não se destacou por suas produções.

Prática comum naquela época, o primeiro casamento de d. Emília havia sido uma imposição de seu pai. Já nos primeiros meses, a jovem esposa percebeu que seria impossível o convívio com o marido, que muito a maltratava, e saiu de casa levando consigo uma filha recém-nascida. Apesar de a sociedade local ter reprovado tal atitude, foi acolhida na casa de amigos. Quinze anos depois do conturbado desenlace, conheceu o futuro pai de Aluísio Azevedo, com quem se casou.

Como d. Emília, David Azevedo era imigrante português, estabelecido no Brasil na segunda metade do século XIX, período de relativo crescimento econômico em São Luís do Maranhão. Jean-Yves Mérian ${ }^{4}$ defende a ideia de que em São Luís do Maranhão, nesse período, havia uma prosperidade apenas aparente, devido à falta de mão de obra e ao incipiente desenvolvimento industrial.

No entanto, não podemos desprezar o fato de que a região teve seus momentos de significativa expansão comercial durante o período de cultivo do algodão. Entre os anos de 1780 e 1820, muitas pessoas enriqueceram com o plantio desse produto, mas essa

\footnotetext{
${ }^{4}$ MÉRIAN, Jean-Yves. Aluísio Azevedo, vida e obra (1857-1913): O verdadeiro Brasil do século XIX. Rio de Janeiro: Espaço e Tempo, 1988, p. 41. Trata-se do mais importante biógrafo de Aluísio Azevedo até o momento. O subtítulo do livro de 660 páginas mostra bem a pretensão e o fôlego do estudioso francês. Além de apresentar dados sobre a vida do escritor, a partir de vasta pesquisa feita em livros e periódicos, Mérian discorre sobre o panorama social e político de São Luís do Maranhão, quando do nascimento e da juventude de Aluísio Azevedo, e do Rio de Janeiro, durante o período em que o escritor morou na então capital do Brasil.
} 
situação se altera com o fim da guerra pela independência nos Estados Unidos, quando esse país voltou a ser o grande produtor de algodão e os maranhenses passaram a enfrentar a concorrência norte-americana.

Na década de 1860, com a Guerra de Secessão, o Maranhão retoma a posição de destaque como grande exportador, principalmente para abastecer as fábricas de tecido da Inglaterra. Contudo, apesar das extensões de terra boa para o plantio, tão logo terminaram os conflitos, os americanos voltaram a abastecer as indústrias têxteis da Europa e o Maranhão perdeu sua prestigiada posição. De qualquer forma, um significativo número de ingleses e portugueses imigrou para a região no século XIX, tendo em vista não apenas o plantio de algodão, mas também a construção de fábricas têxteis e a comercialização de tecidos. É possível que essa prosperidade sazonal tenha levado o português David Gonçalves a se estabelecer como comerciante em São Luís do Maranhão, tornando-se vice-cônsul dois anos após o nascimento de seu filho Aluísio.

A mãe do futuro romancista possuía uma seleta biblioteca e se encarregou da educação inicial dos filhos. Em 1852, por iniciativa do pai, foi organizado no Maranhão o Gabinete de Leitura, uma espécie de clube fechado, restrito aos cidadãos portugueses. O local foi, durante décadas, o ponto de encontro dos homens cultos da cidade. David Gonçalves chegou também a escrever um livro sobre a história de Portugal e foi vicepresidente da Sociedade Dramática de São Luís, dado seu grande interesse por teatro. De acordo com Jean-Yves Mérian:

\begin{abstract}
Aluísio Azevedo não teve o privilégio de ter uma família rica, o que mais tarde dificultaria seus estudos na época em que poderia ter frequentado a universidade de Recife ou do Rio de Janeiro; mas teve a sorte de viver numa das famílias mais cultas de São Luís. Seu pai e sua mãe foram seus primeiros mestres. [...] Podemos verificar que existia na casa de David Gonçalves de Azevedo uma verdadeira escola, paralela com uma pedagogia extremamente moderna, onde o teatro desempenhava papel predominante na formação das crianças. ${ }^{5}$
\end{abstract}

\footnotetext{
${ }^{5}$ MÉRIAN, Jean-Yves. Aluísio Azevedo, vida e obra (1857-1913): O verdadeiro Brasil do século XIX. Rio de Janeiro: Espaço e Tempo, 1988, p. 25.
} 
Nesse espaço acolhedor e estimulante, o pequeno Aluísio e seus irmãos não só representavam obras clássicas de teatro, em salão mandado construir pelo pai especialmente para isso, como encenavam textos escritos por Artur, para os quais Aluísio pintava os cenários, já mostrando seus pendores para as artes plásticas.

Verificada essa inclinação, sua mãe o estimulou a ter aulas de desenho e pintura. Seus primeiros quadros foram retratos encomendados pela burguesia local, atividade bastante rentável na época em que a fotografia ainda dava seus primeiros passos. No entanto, apesar de todos os cuidados dispensados por d. Emília para a formação dos filhos, Aluísio Azevedo só frequentou a escola formal até os 13 anos, quando o pai o empregou como despachante alfandegário no armazém de um amigo da família. Por certo "quis dar a seus filhos uma profissão que lhes garantisse uma vida material decente, pois, no Maranhão, para quem não possuía fortuna pessoal, e era o caso da família Azevedo, a única saída era o comércio". 6

O teatrólogo francês Emílio Rouède (1848-1908), amigo de Aluísio, resume bem as atividades exercidas pelo jovem antes de tornar-se romancista, em artigo publicado na revista A Semana, em 20 de novembro de 1886:

Aluísio Azevedo trabalha desde os doze anos de idade para manter-se; foi mestre-escola, despachante de alfândega, guarda-livros, desenhista de jornal, cenógrafo, professor de desenho em casas particulares, jornalista, retratista, e até gerente de hotel, e tudo isso antes dos vinte anos de idade. ${ }^{7}$

O primeiro livro, Uma lágrima de mulher ${ }^{8}$, publicado em 1879 , foi escrito quando Aluísio Azevedo tinha 17 anos. Ainda não foi encontrado nenhum artigo que confirme sua colaboração na imprensa maranhense antes de sua primeira estada no Rio de Janeiro, mas acredita-se que Aluísio participava dos encontros de jovens positivistas, como Celso Magalhães e Manuel Bithencourt, que publicavam artigos nos jornais $O$

\footnotetext{
${ }^{6}$ MÉRIAN, Jean-Yves. Aluísio Azevedo, vida e obra (1857-1913): O verdadeiro Brasil do século XIX. Rio de Janeiro: Espaço e Tempo, 1988, p. 50.

${ }^{7}$ In: DANTAS, Paulo. Aluísio Azevedo: um romancista do povo. São Paulo: Melhoramentos, 1954. p. 22.

${ }^{8}$ Segundo Jean-Yves Mérian, nesse período Aluísio escreveu também um livro de memórias, ainda inédito, cujo original incompleto pôde folhear nos arquivos de Pastor Azevedo Luquez, em Buenos Aires. Ver MÉRIAN, Jean-Yves. Aluísio Azevedo, vida e obra (1857-1913): O verdadeiro Brasil do século XIX. Rio de Janeiro: Espaço e Tempo, 1988, p. 88.
} 
Seminário e O Domingo, este último dirigido por Artur Azevedo. O grande alvo dos textos publicados por esses jovens maranhenses era o obscurantismo provocado pela Igreja, que impedia o avanço das ideias progressistas. Pode ser que o futuro autor d' $O$ Coruja tenha participado desse grupo entre os 15 e 18 anos, pois só assim entende-se a coerência e o conhecimento de causa por ocasião de sua participação no movimento anticlerical, em 1876, no Rio de Janeiro, conforme veremos no próximo item.

Certo é que, até a publicação de $O$ mulato, em 1881, Aluísio não tinha aspirações de tornar-se romancista. Seu desejo era estudar pintura em Roma, mas não obteve o consentimento do pai, que talvez não pudesse custear essa viagem. Continuou a pintar quadros e chegou a dedicar-se a retratar defuntos, além de trabalhar como professor particular, para conseguir o dinheiro necessário e mudar-se para o Rio de Janeiro.

\subsection{A primeira estada no Rio de Janeiro}

Aos 19 anos, Aluísio Azevedo desembarca no Rio de Janeiro, onde permanecerá de 1876 a 1878. Matricula-se na Imperial Academia de Belas Artes e para se sustentar trabalha como chargista em importantes periódicos da época. As charges e as caricaturas foram amplamente usadas como forma de denunciar os problemas sociais e políticos do Brasil ao longo do Segundo Império e continuaram a sê-lo depois da Proclamação da República. Ângelo Agostini, Rafael Bordalo e Henrique Fleiuss, só para citar alguns, estavam entre os grandes nomes da charge naquela época e Aluísio juntou-se a eles, divulgando seus desenhos em publicações como $O$ Fígaro, $O$ Mequetrefe e na revista A Comédia Popular - nesta última, também assinava crônicas, sob o pseudônimo de Lambertini. Quanto à sua participação nas páginas de A Semana Ilustrada e Zigue-Zague no período, as opiniões dos biógrafos divergem; Raimundo de Menezes $^{9}$ nos assegura a veracidade dessa informação, que é contestada por Mérian. ${ }^{10}$

\footnotetext{
${ }^{9}$ MENEZES, Raimundo de. Aluísio Azevedo, uma vida de romance. São Paulo: Livraria Martins Editora, 1958 , p. 68.

10 "Herman Lima afirma que Aluísio Azevedo assinou alguns desenhos sob o codinome 'Milord' no jornal $O$ Mequetrefe, e foi colaborador de A Semana Ilustrada e Zigue-Zague. Parece-nos difícil fazer essa afirmação". Ver MÉRIAN, Jean-Yves. Aluísio Azevedo, vida e obra (1857-1913): O verdadeiro
} 
Independentemente das controvérsias, vale dizer que em muitas das charges reproduzidas, tanto na obra do biógrafo francês como no livro de Menezes, pode-se constatar a crítica ferrenha contra a Monarquia, a Igreja e os partidos conservadores e em prol do progresso e da República. Em algumas charges é explícita também a influência do Positivismo, como é o caso da intitulada Visão do século $X X$, uma espécie de alegoria do Juízo Final, publicada em $O$ Mequetrefe, ${ }^{11}$ em que se vê Augusto Comte combatendo membros do clero.

Em muitas delas Aluísio ataca diretamente o imperador, por exemplo, na intitulada Um sonho oriental. ${ }^{12}$ Nessa charge, no primeiro plano vê-se imperador fumando um narguilé, enquanto da fumaça expelida saem imagens da vida política e econômica do Brasil (anarquia na Câmara, escândalos financeiros, o uso indevido do poder pela Igreja, a dependência das relações exteriores). Representada à esquerda, em tamanho menor, há uma mulher aos prantos, provavelmente simbolizando a pátria.

Outro setor que recebeu os ataques de Aluísio Azevedo, tanto em charges como em poemas, foi o clero, conforme se pode constatar nos versos seguintes:

\author{
Decepção \\ Chorosa a treva expira e rindo o dia alveja, \\ Fecharam-se os bordéis, abriram-se conventos; \\ Lá vem cambaleando um desses monumentos, \\ Sacerdotes fiéis da Santa Madre Igreja. \\ Enfurecida grei de velhos rabugentos, \\ No sacro atelier, há muito que o almeja: \\ Resmunga daqui um, dali outro pragueja \\ - Que venha um padre já! Com todos os trezentos!... \\ Espalha-se rumor!... psiu!... guincha um velhote; \\ Se acotovela o povo... e passa o sacerdote \\ Mal se podendo ter no vacilante andar. \\ Até que enfim chegou e vagarosamente \\ Começa, beija o chão... embalde espera a gente \\ Há muito ressonava o bruto no altar. ${ }^{13}$
}

\footnotetext{
Brasil do século XIX. Rio de Janeiro: Espaço e Tempo, 1988, p. 107.

${ }^{11}$ Charge reproduzida em MENEZES, Raimundo de. Aluísio Azevedo, uma vida de romance. São Paulo: Livraria Martins Editora, 1958, s/n. Ver anexos.

12 O Mequetrefe, n. 94, Rio de Janeiro, 19 mar. 1877. Charge reproduzida em MÉRIAN, Jean-Yves. Aluísio Azevedo, vida e obra (1857-1913): O verdadeiro Brasil do século XIX. Rio de Janeiro: Espaço e Tempo, 1988, p. 111. Ver anexos.

${ }^{13}$ Apud MENEZES, Raimundo de. Aluísio Azevedo, uma vida de romance. São Paulo: Livraria Martins
} 
Para Mérian, aquele período de rebeldia intelectual foi de grande importância para a definição das diretrizes estéticas e políticas adotadas posteriormente pelo escritor maranhense. ${ }^{14}$ Em suas charges, por exemplo, as linhas traçadas pelas caricaturas sugerem não só seu engajamento na campanha republicana, mas também suas ideias a respeito da criação de uma literatura que retratasse a realidade brasileira da época.

Durante os dois anos e meio em que viveu no Rio de Janeiro, Aluísio Azevedo, além de fazer parte do quadro de chargistas de então, participou de um círculo de intelectuais, artistas e políticos que marcaram a vida cultural e política do país no último quartel do XIX. Desse grupo faziam parte Teixeira Mendes, fundador da primeira igreja positivista do Brasil; Lopes Trovão, ${ }^{15}$ futuro deputado republicano; e o abolicionista José do Patrocínio, e é provável que o convívio com essas pessoas tenha contribuído para fortalecer suas convicções abolicionistas e republicanas. Ideias estas que, como vimos até aqui, já estavam presentes em muitas das charges produzidas pelo artista e serão defendidas em romances escritos posteriormente.

Todavia, Aluísio Azevedo não era o único escritor do Norte que naquele momento encontrava-se na então capital do país e contribuía com suas imagens e palavras para exigir mudanças, tanto no âmbito político como no literário. Nos últimos anos do decênio de 1870, estavam no Rio de Janeiro alguns escritores e intelectuais integrantes da conhecida "Escola do Recife", como Franklin Távora, Tobias Barreto, Sílvio Romero, ${ }^{16}$ que foram muito influenciados pela polêmica provocada pela publicação de As farpas, ${ }^{17}$ de Ramalho Ortigão e Eça de Queirós.

\footnotetext{
Editora, 1958, p. 6.

${ }^{14}$ MÉRIAN, Jean-Yves. Aluísio Azevedo, vida e obra (1857-1913): O verdadeiro Brasil do século XIX. Rio de Janeiro: Espaço e Tempo, 1988, p. 108.

${ }^{15}$ Lopes Trovão e José do Patrocínio, assim como Aluísio Azevedo, foram colaboradores do jornal Gazetinha, fundado, em 1880, por Artur Azevedo. Mas a amizade dos irmãos Azevedo com esses e outros expoentes da política vinha desde 1877, quando Artur assumiu a direção da Revista do Rio de Janeiro. Ver SODRÉ, Nelson Werneck. História da imprensa no Brasil. São Paulo: Martins Fontes, 1983 , p. 246.

16 Segundo Antonio Candido, "Sílvio Romero foi, a falarmos com rigor, o primeiro grande crítico e fundador da crítica no Brasil. Protagonista do movimento do Recife - um dos focos do grande movimento renovador da mentalidade brasileira na segunda metade do século XIX”. In: O método crítico de Sílvio Romero. São Paulo: Edusp, 1988, p. 9.

17 As farpas foram crônicas publicadas mensalmente a partir de maio de 1871 , no mesmo ano da realização das Conferências do Cassino, por Eça de Queirós e Ramalho Ortigão. Em novembro de 1872, Eça abandona a publicação para seguir carreira diplomática, deixando a tarefa para Ramalho Ortigão, que prossegue com as publicações até 1882. Altamente críticos e irônicos, esses artigos satirizavam questões
} 
Também residiam na então capital do Brasil, nesse momento de grande efervescência da chamada "geração de 1870", alguns ex-integrantes da "Academia Francesa de Fortaleza", ${ }^{18}$ como o historiador Capistrano de Abreu, o crítico e escritor Araripe Júnior e aquele que viria a ser o primeiro grande crítico de Machado de Assis, José Veríssimo.

Como exemplo do teor das discussões desse período, vale citar Franklin Távora, que, em 1872, publicara uma série de artigos no Jornal de Recife, por meio dos quais questionava os conceitos literários de José de Alencar. ${ }^{19}$ Mas suas críticas não ficaram restritas ao âmbito da imprensa; seus romances $O$ matuto (1876) e O cabeleira (1878), também foram utilizados como tribuna para discutir suas teorias sobre o que ele chamava de "romance histórico", conforme se pode constatar em trechos de cartamanifesto dirigida ao leitor, apresentada na abertura de $O$ cabeleira:

Em $O$ cabeleira ofereço-te um tímido ensaio do romance histórico, segundo entendo este gênero da literatura. [...] As letras têm, como a política, um certo caráter geográfico; mais no Norte, porém, do que no Sul abundam os elementos para a formação de uma literatura propriamente brasileira, filha da terra.

A razão é óbvia: o Norte ainda não foi invadido como está o Sul de dia em dia pelo estrangeiro. ${ }^{20}$

Segundo Mérian, Franklin Távora poderia ter sido o precursor do Naturalismo com as duas obras supracitadas, mas o pouco alcance de suas produções à época ambas tiveram uma edição de apenas 500 exemplares - restringiu a difusão e impediu que fossem lidas pela crítica de maneira correta. "Algumas centenas de exemplares

\footnotetext{
de ordem política, econômica, cultural e social de Portugal da Regeneração.

${ }^{18}$ Academia Francesa foi nome dado a uma comunidade informal criada, entre 1872-1878, em Fortaleza, por intelectuais como Rocha Lima, Capistrano de Abreu, Araripe Júnior, dentre outros. Nas reuniões do grupo, que geralmente ocorriam na residência dos membros, discutiam-se temas como filosofia, ciência, problemas sociais, liberdade religiosa e instrução pública. Segundo Afrânio Coutinho, trata-se de "[...] agremiação intelectual que teve grande papel na divulgação da ideias características do final do século". Ver COUTINHO, Afrânio; COUTINHO, Eduardo de Faria. A literatura no Brasil: era Realista, era de transição. 4. ed. revista e ampliada. São Paulo: Global, 1997, p. 28.

${ }^{19}$ Ficou célebre a intensa campanha desfechada por Franklin Távora contra o romancista José de Alencar. Por meio de uma série de artigos em forma de cartas, usando o pseudônimo Simprônio, Franklin Távora criticou, sobretudo, os romances $O$ gaúcho e Iracema, apontando a incorreção de linguagem e censurando Alencar por não conhecer o cenário geográfico de seus romances.

${ }^{20}$ TÁVORA, Franklin. "Prefácio do autor". In: O cabeleira. São Paulo: Editora Três, 1973. [s/p].
} 
passaram quase despercebidas pela crítica e não influenciaram muito na evolução do gênero naturalista no Brasil". ${ }^{21}$ No entanto, a amplitude de suas ideias, publicadas em jornais da época, pode ter contribuído para o progresso da estética realista no Brasil.

Para Nelson Werneck Sodré também foi a pouca divulgação o entrave para que Inglês de Souza não tivesse o mérito de ser o precursor do Naturalismo no Brasil, com a obra $O$ coronel sangrado:

O coronel sangrado, de Inglês de Souza, publicado em 1877, revela muito mais traços naturalistas do que $O$ mulato, aparecido quatro anos depois e aceito como marco inicial da nova escola entre nós. Mesmo $O$ cacaulista, de 1876, revela em Inglês de Souza a intenção e o domínio de técnicas e processos naturalistas que Aluísio não revela no seu livro tão conhecido. [...]

Inglês de Souza não conseguiu, entretanto, estabelecer o contato, a comunicação, com o público, e permaneceu praticamente esquecido por longos anos, embora a crítica do tempo o tivesse considerado na medida de suas qualidades. Escreveu os seus primeiros livros antes da voga de Zola e Eça de Queirós no Brasil. ${ }^{22}$

Não podemos afirmar que Aluísio Azevedo tenha lido obras de Franklin Távora e Inglês de Souza, mas certamente leu Eça de Queirós, como também participou da querela entre românticos e realistas, em que estiveram envolvidos grandes escritores e críticos do período, como Ramalho Ortigão e Machado de Assis.

Sobre as acaloradas discussões em torno dessa questão, transcrevemos trecho de Araripe Júnior para ilustrar a sua proporção:

- Ainda tenho presente a sensação que me causou, não o Primo Basílio, pois que, já em 1874, eu, então residente na província do Ceará, lera o Crime do Padre Amaro na Revista Ocidental, mas a febre de que estavam possuídos, em vista daquele livro, alguns rapazes, com particularidade José do Patrocínio, que escrevia o Mota

\footnotetext{
${ }^{21}$ WERNECK, Nelson apud MÉRIAN, Jean-Yves. Aluísio Azevedo, vida e obra (1857-1913): O verdadeiro Brasil do século XIX. Rio de Janeiro: Espaço e Tempo, 1988, p. 125.

${ }^{22}$ Idem, p. 209.
} 
Coqueiro na Gazeta de Notícias. Era no café Londres, e, pela primeira vez, me apresentavam ao escritor que fazia as suas primeiras armas. Em seguida a uma ligeira conversação, passou-se à questão do dia. - Mas qual a questão? Inquiri eu, com alguma timidez, por que, devido a circunstâncias particulares de deslocação de meio, andava à gaita em matéria de letras.

- Qual a questão?

- O Primo Basílio! Eça de Queirós. Uma revolução! O diabo! O realismo! Românticos enfocés! [...]

Os interlocutores me pareceram inebriados. Nós somos todos assim... E então os projetos choveram. O Realismo no Brasil havia de ser descascado com uma ferocidade que assombraria ao próprio Eça de Queirós. $^{23}$

A querela tem início em 1878, quando Ramalho Ortigão começa a assinar a seção intitulada "Cartas Portuguesas", na Gazeta de Notícias do Rio de Janeiro. A primeira delas trata justamente da publicação da obra O Primo Basílio, de Eça de Queirós. Pelo que pudemos constatar nas impressões registradas por Araripe Júnior, Ramalho Ortigão era um crítico bastante lido e respeitado à época e sua opinião sobre a obra de Eça de Queirós pode ter influenciado os jovens escritores e jornalistas brasileiros.

Logo depois da publicação dessa carta, o livro de Eça foi colocado à venda nas livrarias do Rio de Janeiro e Machado de Assis, sob o pseudônimo de Elieser, escreve contundente crítica ao romance. Tem início então uma verdadeira disputa entre "antigos e modernos", da qual Aluísio Azevedo participou com a charge Romantismo e Realismo: luta aberta, ${ }^{24}$ tomando partido do grupo realista. Na charge vê-se um balcão de onde Elvira, de olhos vendados, simbolizando a poesia, assiste a um embate entre D. Juan, de espada na mão, representante do Romantismo, e Basílio, representando o Realismo, empunhando um revólver.

\footnotetext{
${ }^{23}$ JÚNIOR, Araripe. A obra crítica de Araripe Júnior .v. 1. Rio de Janeiro: Casa de Rui Barbosa, 1958, p. 75.

${ }^{24}$ Charge publicada em A comédia popular, Rio de Janeiro, 5/04/1878. In: MÉRIAN, Jean-Yves. Aluísio Azevedo, vida e obra (1857-1913): O verdadeiro Brasil do século XIX. Rio de Janeiro: Espaço e Tempo, 1988, p. 135. Ver anexos.
} 
Podemos afirmar, portanto, que Aluísio Azevedo, já na sua primeira estada no Rio de Janeiro, não só teve contato com a obra de Eça de Queirós, como leu as ideias de Ramalho Ortigão, publicadas no Brasil, diferentemente do que afirma Raimundo de Menezes, ao dizer que Aluísio Azevedo só veio a conhecer a obra de Eça quando da sua volta para São Luís. ${ }^{25}$

Mérian afirma que não há indicações concretas de que, na época dessa polêmica em torno da disputa estética entre românticos e realistas, Aluísio Azevedo tenha tido contato com a obra de Zola. ${ }^{26}$ Todavia, sabe-se que o escritor maranhense lia francês e que seu pai mantinha no Gabinete de Leitura obras de indiscutível qualidade literária. Não teria tido ali conhecimento da obra do grande expoente do Naturalismo? Fato que comprovaria o interesse de Aluísio pela leitura de autores franceses realistas no período é confirmado pelo próprio Mérian, que nos informa que Un coeur simple ${ }^{27}$ foi publicado, em 1880, em forma de folhetim no Pacotilha - periódico que contou com a participação de Aluísio Azevedo -, ou seja, bem pouco depois da querela entre românticos e realistas. Saber que o futuro autor d'O cortiço era um leitor de Flaubert também é importante para aproximação que faremos entre L'éducation sentimentale e O Coruja no terceiro capítulo deste estudo.

De qualquer forma, a presença dos autores portugueses na juventude do escritor é inegável, tanto em sua primeira estada no Rio de Janeiro, como em sua produção posterior como jornalista e romancista. Mas, se por ora estamos tratando apenas do âmbito da recepção durante os anos de formação de Aluísio, nos próximos capítulos tangenciaremos seu talento individual, partindo do pressuposto de que o então estreante romancista talvez tenha seguido o conselho dado por Araripe Júnior, quando do lançamento de $O$ mulato:

\footnotetext{
${ }^{25}$ Ao escrever sobre a influência de Celso Magalhães na formação de Aluísio Azevedo, quando o escritor retorna para São Luís e começa a produzir $O$ mulato, Raimundo Magalhães afirma: "Seu autor pensa agora na composição de outro romance, bem diferente do primeiro [refere-se a Uma lágrima de mulher] através de Celso Magalhães trava conhecimento com Eça de Queiroz. Lê e aprecia 'O Primo Basílio', cheio de cenas escabrosíssimas. Devora de um jato 'O Crime do Padre Amaro"'. In: MENEZES, Raimundo de. Aluísio Azevedo, uma vida de romance, São Paulo: Livraria Martins Editora, 1958, p. 84.

26 "Mas se podemos afirmar que Aluísio Azevedo conhecia as obras de Eça de Queirós, não podemos afirmar que lera as obras de Zola." MÉRIAN, Jean-Yves. Aluísio Azevedo, vida e obra (1857-1913): O verdadeiro Brasil do século XIX. Rio de Janeiro: Espaço e Tempo, 1988, p. 138.

${ }^{27}$ Trata-se da novela "Um coração simples", de Gustav Flaubert, publicada na obra Três contos (1877), da qual fazem parte também "Herodíade" e a "Lenda de São Julião".
} 
Se fôssemos papa em literatura, daríamos a Aluísio Azevedo a nossa benção e um importante conselho. Este conselho reduzir-se-ia ao seguinte: - "O poeta, ó romancista, o mundo não se acaba; e, no meio da complexidade de tendências tão variadas para gêneros tão opostos, há de haver, por certo, espaço amplo por onde corra a veia da inspiração aluisiana." 28

Como visto até aqui, tudo indica que a situação de Aluísio Azevedo como chargista e cronista ia de vento em popa na então capital do Brasil, mas a morte repentina do pai obriga-o a voltar para o Maranhão. Abandonou suas atividades e retornou à cidade natal para cuidar da mãe e dos irmãos menores, a despeito de esta decisão pesar, e muito, na sua promissora carreira.

\subsection{De volta ao Maranhão}

Ao retornar à terra natal, Aluísio constata que ocorreram algumas mudanças durante os quase três anos em que esteve fora de São Luís: a Biblioteca Popular fora fechada $^{29}$ por falta de verba e o Gabinete Português de Leitura estava à beira da falência, embora contasse com cerca de 8.000 exemplares. Além disso, apenas três jornais disputavam a preferência do público:

Publicador Maranhense, fundado em 1841 e dirigido pelo major Inácio José Ferreira; $O$ País, lançado em 1860 por Temístocles Aranha; e o Diário do Maranhão, publicado desde 1873 por José Maria Correia de Frias. Estes dois últimos eram, de longe, os mais importantes pela tiragem (em torno de 2.000 exemplares), pelos temas abordados e pela qualidade dos colaboradores. ${ }^{30}$

\footnotetext{
${ }^{28}$ JÚNIOR, Araripe. A obra crítica de Araripe Júnior. v. 1. Rio de Janeiro: Casa de Rui Barbosa, 1958, p. 121.

${ }^{29}$ A Biblioteca Popular, fundada em 1872, com apoio da população local, chegou a possuir 4.000 volumes à época e foi forçada a suspender as atividades em 1875. Só foi reaberta em 1892. Em 1958, foi denominada Biblioteca Pública "Benedito Leite". Cf. MÉRIAN, Jean-Yves. Aluísio Azevedo, vida e obra (1857-1913): O verdadeiro Brasil do século XIX. Rio de Janeiro: Espaço e Tempo, 1988, p. 73.

${ }^{30}$ Idem, p. 146.
} 
No entanto, entre 1878 e 1881, cinco outras publicações surgiram: O Futuro, criado por Manuel Bithencourt para defender suas ideias positivistas; A Flecha, lançado por Aluísio Azevedo e João Afonso do Nascimento, em março de 1879, e que circulou até outubro de 1880; O Pensador, sob direção de jovens progressistas, entre eles Aluísio Azevedo; e Pacotilha, também criado e dirigido pelo escritor e o seu futuro cunhado, Vitor Lobato. Essas publicações formavam uma espécie de plataforma para combater a escravatura e lutar a favor da Proclamação da República. ${ }^{31}$

Para defender os interesses católicos e, principalmente, fazer oposição às ideias postuladas por integrantes das outras quatro publicações, membros da diocese inauguraram o semanário Civilização.

A participação de Aluísio Azevedo na imprensa local nessa época foi intensa, sobretudo no periódico Pacotilha, que chegou a publicar 300 exemplares por dia. Seus textos desse período denunciam a hipocrisia da sociedade de São Luís do Maranhão, bastante conservadora à época. As disputas constantes entre os jovens positivistas e a Igreja tornavam-se cada vez mais acirradas. Aluísio Azevedo, que inicialmente assinava sob pseudônimo, passou a assumir a autoria das crônicas e matérias que escrevia. Sobre o teor desses textos, vale citar novamente Mérian:

Como cronista, Aluísio Azevedo assumiu um papel de primeira linha em $O$ Pensador. No plano do estilo, suas crônicas possuíam muitos pontos em comum com Farpas de Ramalho Ortigão. Inclusive ele era considerado como discípulo do escritor português e reconhecia-se como tal. O combate anticlerical representava uma parte importante de cada crônica. Ele estigmatizava o obscurantismo da Igreja, a ignorância, o dogmatismo e o fanatismo dos padres. ${ }^{32}$

\footnotetext{
31 "Na ausência de um verdadeiro partido republicano em gestação, Aluísio Azevedo e a jovem geração travavam um combate por uma mudança de sociedade que atingisse não apenas a natureza do regime político, como todos os campos de atividades. Convém então fazer a diferença entre a atividade de um partido republicano esquelético e a ideia republicana, defendida pelos jovens intelectuais maranhenses (na maioria dos casos mais saídos das classes médias que da oligarquia fundiária) nos jornais $A$ Flecha, $O$ Pensador, Pacotilha, O Futuro e também nos dois principais diários: O País e Diário do Maranhão." MÉRIAN, Jean-Yves. Aluísio Azevedo, vida e obra (1857-1913): O verdadeiro Brasil do século XIX. Rio de Janeiro: Rio de Janeiro: Espaço e Tempo, 1988, p.150.

${ }^{32}$ Idem, p. 158.
} 
Todavia, não demorou muito para que Aluísio Azevedo e seus amigos começassem a ser vítimas de várias perseguições. Chegou mesmo a ser instaurado um processo contra os idealizadores do jornal $O$ Pensador. E a situação ficou ainda mais acirrada depois da publicação d' $O$ mulato (1881), obra em que o escritor não apenas faz críticas severas à Igreja e ataca os horrores da escravidão, como também retrata pessoas de seu convívio: padres, alcoviteiras, comerciantes, políticos se veem explicitamente retratados, o que aumenta ainda mais os ataques contra ele. Sobre esse romance, escreve Capistrano de Abreu:

[...] $O$ Mulato não é um romance positivista, não se pode rigorosamente dizer que seja abolicionista. Muitas vezes se trata nele de escravidão - aqui mostrando a barbaria dos senhores, ali apontando a corrupção inoculada na família pelas vítimas algozes; além formulando argumentos contra este cancro social. [...] Apesar disto, repetimos, o romance não é abolicionista: tudo quanto se refere à escravidão é antes uma das paisagens que se debruçam à beira do caminho, do que objeto essencial da jornada.

O que o romance é essencialmente é um romance realista que, como tentativa, é muito notável. Nas primeiras páginas o autor inspira-se evidentemente no estilo de Zola, Eça de Queirós e, Deus lhe perdoe!, de Euzébio Macário; ${ }^{33}$ mas em breve se emancipa, e os períodos saem-lhe fluentes. Ágeis, abundantes, a latejarem vida como um formigueiro. $^{34}$

Durante o período em que voltou a morar em São Luís do Maranhão, além de sua intensa participação na imprensa e da criação da obra $O$ mulato, Aluísio Azevedo também contribuiu ativamente para a produção teatral da cidade. Muitos de seus artigos publicados na época são em favor dessa manifestação artística.

Na companhia de amigos como Vítor Leal e Euclides Faria, o escritor chegou a planejar a construção de um teatro novo, onde só seriam representadas obras realistas, mas o projeto não saiu do papel.

\footnotetext{
${ }^{33}$ Capistrano refere-se à novela Eusébio Macário, de Camilo Castelo Branco, escrita em 1879.

${ }^{34}$ ABREU, Capistrano. Ensaios e Estudos. 4. ${ }^{a}$ série. Rio de Janeiro: Civilização Brasileira, 1976, p. 260.
} 
Em uma das crônicas publicadas em $O$ Pensador, em resposta às críticas feitas pelo redator do jornal Civilização às suas ideias progressistas sobre o teatro, pode-se constatar sua opinião sobre a grandeza da arte cênica. Nota-se também que, na época da produção de $O$ mulato, já travara conhecimento com a obra de Zola:

O teatro é o templo das artes, é um enorme "atelier" onde colaboram artistas e operários de todos os gêneros; a "mise em scène", a cenografia, a arquitetura, a orquestra, tudo isso representa o trabalho, o santo trabalho, abençoado por Deus. Ali cansa o ator, desenvolvese o poeta, sua o marceneiro, exibe-se a moda, pintam-se os costumes, aprende o público a falar, a estar em sociedade e é pena que V. Revma não frequente as plateias e só conheça necessariamente o teatro antigo, porque então saberia que os dramas modernos de Dumas filho e Emílio Zola, de Sardou etc., ensinam os inexperientes a conhecer o mal, desmascaram os perigos, os escolhos da sociedade em que temos de andar, abrem os olhos dos moços e enchem-lhes o coração de esperança, de força, de energia e de amor. $^{35}$

Apesar da intensa participação na imprensa maranhense, as críticas constantes publicadas pelos clérigos no jornal Civilização e a boa recepção de $O$ mulato no Rio de Janeiro contribuíram para que o jovem escritor decidisse pela mudança definitiva para a capital do Brasil.

Todavia, essa atuação na imprensa maranhense certamente corroborou para sua formação como escritor, como afirma Josué Montello: "Essa passagem pelo jornalismo tem grande importância no destino do escritor: torna-lhe o estilo mais vivo, imprimelhe maior poder de objetividade e apara-lhe as rebarbas adquiridas na leitura dos poetas e prosadores românticos. O jornal acelera a evolução do escritor". ${ }^{36}$

\footnotetext{
${ }^{35}$ MÉRIAN, Jean-Yves. Aluísio Azevedo, vida e obra (1857-1913): O verdadeiro Brasil do século XIX. Rio de Janeiro: Espaço e Tempo, 1988, p. 177.

${ }^{36}$ Ver MENEZES, Raimundo de. Aluísio Azevedo, uma vida de romance. São Paulo: Livraria Martins Editora, 1958, p. 99.
} 


\subsection{A consagração como romancista}

Uma vez instalado no Rio de Janeiro, Aluísio Azevedo deu início à produção de seu primeiro folhetim, Memórias de um condenado que, ao ser publicado em livro, recebeu o título de $A$ condessa Vésper. ${ }^{37}$ Em 1882, escreve a opereta A flor-de-lis, em parceria com Artur Azevedo, que, segundo João Roberto Faria:

[...] foi bem-sucedida, não só porque satisfazia o gosto do grande público com a música e a licenciosidade típica do gênero, mas também porque o Imperador D. Pedro II, presente à estreia, abandonou o teatro antes de terminado o espetáculo, escandalizado talvez com a brejeirice da peça. Essa atitude provocou vários comentários na imprensa e despertou obviamente a curiosidade pública. $^{38}$

Nesse mesmo ano é publicado o folhetim Mistérios da Tijuca, ${ }^{39}$ editado em livro sob o título Girândola de amores. Em seguida, escreve Casa de pensão (1884), inspirado em crime ocorrido sete anos antes, e que fora intensamente tratado pela imprensa do Rio de Janeiro. O lançamento do romance foi um verdadeiro sucesso, três edições esgotaram-se rapidamente no mesmo ano de lançamento. Ainda em 1884, adaptou $O$ mulato para o teatro e produziu o folhetim Filomena Borges, publicado pelo jornal Gazeta, que também teve versão do escritor para o teatro.

Como dramaturgo, escreveu também as peças Venenos que curam, que posteriormente recebeu o título de Lição para marido (1885), O caboclo (1886), Um caso de adultério e Em flagrante, ambas em 1890, todas em parceria com o amigo francês Emílio Rouède. Com o irmão Artur de Azevedo assinou Fritzmark (1888) e A República (1890). É de sua autoria também Macaquinhos no sótão, comédia em três

\footnotetext{
37 "As Memórias de um condenado saem depois em livro, isto pelas alturas de 1886, composto e impresso nas oficinas gráficas do Liberal Mineiro, de Ouro Preto. Quando Aluísio Azevedo entrega os originais, para uma terceira edição, à Livraria Garnier, é que troca o nome para A Condessa Vésper". MENEZES, Raimundo de. Aluísio Azevedo, uma vida de romance. São Paulo: Livraria Martins Editora, 1958, p. 142.

${ }^{38}$ FARIA, João Roberto. Teatro de Aluísio Azevedo e Emílio Rouède. São Paulo: Martins Fontes, 2002. p. XII.

${ }^{39}$ Mistérios da Tijuca recebe o título de Girândolas de amores quando foi publicado, em 1900, pela Garnier. Ver MENEZES, Raimundo de. Aluísio Azevedo, uma vida de romance. São Paulo: Livraria Martins Editora, 1958, p. 145.
} 
atos, encenada em 1887, que posteriormente recebeu o título Os sonhadores.

Em 1885, escreve Mattos, Malta ou Matta?, novela policial, publicada na revista A Semana. Obra que só foi editada em livro na década de 1980. Talvez isso explique o fato de não figurar em muitas biografias e cronologias sobre o autor. ${ }^{40}$

O romance $O$ Coruja começa a figurar como folhetim no rodapé do jornal $O$ Paiz em $1885 .^{41}$ É neste mesmo ano que Aluísio Azevedo divulga nota sobre o projeto de urdir um ciclo de romances, ${ }^{42}$ tal como fizera Zola em Rougon-Macquart, na França. Sobre esse plano, Lúcia Miguel-Pereira comenta:

Talvez se possa ver neste projeto um reflexo dos Rougon-Macquart, mas a concepção é profundamente brasileira, tentando fixar tipos bem nossos, e marcando, nessa mistura de mestiços, filhos de imigrante português, com a família burguesa, um aspecto da verticalidade social que tanto concorreu para a nossa formação. Se o levasse a cabo, teria Aluísio Azevedo feito uma grande obra, cuja realização se deverá em parte, provavelmente, às injunções econômicas, em parte à excessiva sujeição a postulados arbitrários, que contrariavam o temperamento e a vocação romancista. ${ }^{43}$

Ainda que o ciclo de romances tenha malogrado, Aluísio utilizou parte das ideias

\footnotetext{
${ }^{40}$ A novela Mattos, Malta ou Matta? foi publicada pela Nova Fronteira em parceria com a Fundação Casa de Rui Barbosa em 1985. O texto foi apurado pelo setor de filologia da Fundação Casa Rui Barbosa, sob a orientação de Adriano da Gama Kury, e conta com prefácio de Plínio Doyle e posfácio assinado por Alexandre Eulálio, em que estão devidamente explicadas as circunstâncias de criação da obra por Aluísio Azevedo.

${ }^{41}$ Ainda nesse período, Aluísio Azevedo chegou a publicar três capítulos da novela autobiográfica Ruy Vaz, cenas da vida boêmia, na revista A Semana. Segundo Alexandre Eulálio: "Não é impossível que o prosseguimento desta narrativa tenha sido interrompido pela revisão final de $O$ Coruja, apalavrado para sair na "folha do Sr. Quintino"; ao mesmo tempo, Mattos, Malta ou Matta?, já então "romance ao correr da pena", encaminhava-se para o desfecho, dele também exigindo atenção. ${ }^{41}$ EULÁLIO, Alexandre. "Antes do romance". In: AZEVEDO, Aluísio. Mattos, Malta ou Matta? Rio de Janeiro: Nova Fronteira/Fundação Casa de Rui Barbosa, 1985, p. 29.

${ }^{42}$ A obra que preocupa agora o espírito do nosso romancista, e que será talvez seu trabalho de maior fôlego, tem por título "Brasileiros antigos e modernos" e consta de cinco livros, do tamanho cada um de "Casa de pensão", a saber: 1. O cortiço, 2. A família brasileira, 3. O felizardo, 4. A loureira, 5. A bola preta. Esta obra, unida por uma teia geral que atravessa desde o primeiro até ao último livro, representará todavia cinco romances, perfeitamente completos, cada um dos quais poderá ser lido em separado. A ação principia no tempo da Independência e acabará, segundo espera o autor, pelos meados do ano que vem, ou talvez do imediato, isto é, começa em 1820 e acaba em 1887. Ver MENEZES, Raimundo de. Aluísio Azevedo, uma vida de romance. São Paulo: Livraria Martins Editora, 1958, p. 211 e 212.

${ }^{43}$ MIGUEL-PEREIRA. Lúcia. História da literatura brasileira, v. XII. Rio de Janeiro: José Olympio, 1957, p. 137.
} 
nos romances $O$ Coruja, $O$ homem e, principalmente, em $O$ cortiço. Em $O$ homem, o tema da histeria organiza a estrutura do romance, cujo núcleo principal repousa na evolução da doença de Madalena. Lançado em 1888, o livro provocou enorme controvérsia. Alguns críticos consideram que foi durante essa produção que o autor radicalizou sua visão estética, aderindo mais abertamente ao modelo do Romance Experimental, teorizado por Zola. Fato é que foi um verdadeiro sucesso de vendagem: três edições de 1.900 exemplares esgotaram-se entre outubro e dezembro de $1888 .{ }^{44}$

Logo depois da publicação de $O$ homem, vem a lume uma reedição de $O$ mulato, sobre a qual Laura Camilo dos Santos Cruz afirma: "Aluísio Azevedo, ao dar à publicação a segunda versão impressa, em 1899, introduz mudanças significativas que demonstram sua intenção de aperfeiçoar a linguagem, aproximando-a mais e mais da linguagem do naturalismo". 45

Um ano depois, lança $O$ cortiço, considerado pela crítica seu melhor romance, e O Coruja recebe a terceira edição, agora pela Editora Garnier Frères.

Apesar do sucesso de público, alcançado com sua vasta produção, o escritor continuou a produzir folhetins para manter-se financeiramente. Escreve A mortalha de Alzira, na Gazeta de Notícias, sob o pseudônimo Vítor Leal, em 1891. Interessante observar que Aluísio até então assinava todas as suas produções, mesmo as folhetinescas. Talvez, nesse ponto da carreira, já assumidamente um seguidor da estética naturalista, pretendesse não misturar a qualidade alcançada com a escrita de Casa de pensão e $O$ cortiço com obras escritas ao correr da pena para garantir a subsistência material.

Em carta destinada a Afonso Celso, em 25 de novembro de 1884, o escritor pede ao amigo, então deputado geral por Minas Gerais, alguma colocação em cargo público. Nesta, verifica-se o desejo de Aluísio Azevedo de ter mais tempo para dedicar-se à literatura, mas nota-se também que tinha consciência do hibridismo de suas criações:

Há certos lugares, certos cargos, certos empregos, dos quais só os

\footnotetext{
${ }^{44}$ MÉRIAN, Jean-Yves. Aluísio Azevedo, vida e obra (1857-1913): O verdadeiro Brasil do século XIX. Rio de Janeiro: Espaço e Tempo, 1988, p. 434.

${ }^{45}$ CRUZ, Laura Camilo dos Santos. O naturalismo em cena: estudo da evolução da linguagem naturalista de Aluísio Azevedo em $O$ Mulato sob uma perspectiva genética. São Paulo: FFLCH/PROEX-CAPES, 2008, p. 60.
} 
próprios políticos têm notícia quando eles ainda se acham vagos, e que, ao transpirarem cá fora, ao caírem no conhecimento do público, vêm logo, como uma mulher bonita, escoltados por um enxame de cobiçosos e guardados à vista pelo feliz mortal que mereceu a preferência e já traz a nomeação no bolso.

Ora, dessa forma, só fazendo como neste momento faço: vindo a ti e pedindo-te que, logo que passe pelos olhos um desses cargos, lhe ponhas a mão em cima e me atires com ele, que eu o receberei com melhor vontade do que a de um náufrago ao receber a tábua de salvação. Repito: seja lá o que for: tudo serve; conquanto que eu não tenha de fabricar Mistérios da Tijuca e possa escrever Casas de pensão. $^{46}$

Aluísio Azevedo, no entanto, não conseguiu o tão almejado emprego público, condição que favoreceu a produção de muitos escritores da segunda metade do XIX, como Machado de Assis, ${ }^{47}$ Joaquim Manuel de Macedo e Artur Azevedo. Mas chegou a ocupar, por seis meses, em 1891, o cargo de Oficial Maior da Secretaria de Negócios do Governo do Estado do Rio de Janeiro. Todavia, o escritor foi exonerado tão logo Floriano Peixoto assumiu a presidência no lugar do marechal Deodoro da Fonseca. Tal dificuldade de conseguir um emprego público pode ter sido reflexo de suas posições políticas explicitamente defendidas tanto na imprensa como no teatro. ${ }^{48}$

Em 1893, vem a lume o livro de contos Demônios, que já estava havia algum tempo nas mãos do editor, como nos informa o próprio escritor:

Aluísio Azevedo tem, há quase ano e meio, um volume de contos a

\footnotetext{
46 AZEVEDO, Aluísio. Touro negro. São Paulo: Livraria Martins Editora, 1961, p. 192. Obra organizada postumamente, com objetivo de reunir cartas e algumas crônicas para compor as obras completas publicadas, no decorrer da década de 1960, pela Livraria Martins Editora.

47 "Como deixar de compreender a vocação para a burocracia daqueles que não exerciam uma profissão liberal? Machado de Assis representa neste ponto um exemplo muito significativo. Em 1888, ele ganhava oito contos (8.000\$000) por ano, como diretor da Diretoria Geral do Comércio (cargo de alto funcionário), ou seja, duas vezes mais o salário de um redator de um jornal importante do Rio de Janeiro". Ver MÉRIAN, Jean-Yves. Aluísio Azevedo, vida e obra (1857-1913): O verdadeiro Brasil do século XIX. Rio de Janeiro: Espaço e Tempo, 1988, p. 397.

48 "Os ataques diretos e violentos que chegavam a atingir o imperador em pessoa, como em Filomena Borges, a sátira constante em seus romances-folhetins contra o nepotismo e todas as formas de favoritismo que, segundo ele, eram características do regime imperial, e, finalmente, sua ação antimonarquista no teatro e na imprensa, lhe trouxe sem dúvida tenazes inimizades no seio da classe dirigente." Ver MÉRIAN, Jean-Yves. Aluísio Azevedo, vida e obra (1857-1913): O verdadeiro Brasil do século XIX. Rio de Janeiro: Espaço e Tempo, 1988, p. 405.
} 
publicar-se na casa Mont'Alverne, hoje companhia editora; e, apesar de haver pago adiantado a primeira folha de composição, ainda não teve o prazer de ver uma página impressa do seu livro; outros homens de letras queixam-se de iguais contrariedades, e não é natural que alguém se disponha a escrever com boa vontade, tendo uma obra encalhada no prelo. ${ }^{49}$

Seu último romance, Livro de uma sogra, é editado pela Garnier em 1895. Neste mesmo ano, presta concurso e é nomeado vice-cônsul. Dois anos depois de ingressar na diplomacia, Aluísio Azevedo vende os direitos de suas obras completas para a Garnier, que publica a antologia de contos Pegadas (1898), que incluía sete contos já presentes em Demônios, alguns bastante modificados, acompanhados de textos inéditos.

\subsection{O desafio de viver da própria pena}

Lajolo e Zilberman discordam com muita pertinência da premissa de que "na tradição dos estudos literários, não é de bom tom misturar questões de dinheiro com literatura, apagando-se o caráter econômico das atividades culturais". 50

Ao que tudo indica, Aluísio Azevedo estava entre os poucos romancistas brasileiros de seu tempo ${ }^{51}$ que não tinha nenhum pejo em abordar o caráter econômico de suas criações, e muito cedo assumiu publicamente seus planos de sobreviver exclusivamente do seu ofício de escritor, ainda que tivesse consciência do que isso significava no Brasil de então. Este fato pode ser constatado em diálogo travado com Coelho Neto:

\footnotetext{
49 "Literatura nacional". Artigo publicado por Aluísio Azevedo em $O$ Combate, em 10 de março de 1892. In: AZEVEDO, Aluísio. Touro negro. São Paulo: Livraria Martins Editora, 1961, p. 77-8.

${ }^{50}$ LAJOLO, Marisa e ZILBERMAN, Regina. O preço da leitura. São Paulo: Ática, 2001. p.71.

${ }^{51}$ Em seu estudo sobre os leitores de Machado de Assis, Hélio de Seixas Guimarães faz interessante comentário sobre os problemas apontados por Alencar e Aluísio em períodos distintos: "Embora os problemas diagnosticados por Alencar na década de 1860, e por Azevedo, na década de 1880, fossem muito semelhantes, há diferença em como esses escritores emblemáticos de suas gerações explicavam as dificuldades e se referiam ao público leitor. Num primeiro momento supõe-se a existência de um público numeroso, mas caprichoso e indolente, como acreditavam Alencar e os primeiros românticos; num segundo momento, a pouca repercussão da literatura é associada à exiguidade do público leitor.” In: $O s$ leitores de Machado de Assis: O romance machadiano e o público de literatura no século 19. São Paulo: Nankin/Edusp, 2004, p. 82.
} 
- Escrevo por força da fatalidade, como claudicaria, se houvesse nascido coxo; impulso de genitura, não de ideal. É o destino que me aferra a esta mesa, que me debruça sobre tiras. Assim como descrevo um episódio ou uma paisagem e desenvolvo um diálogo, cortaria peças de fazendas ou mantas de carne-seca, se tivesse vindo fadado para o comércio. Vim consignado às letras e aqui estou, falido. A sociedade não admite vadios, todo homem tem que dizer a que veio, que faz, como e para que vive. Eu, a tais perguntas, respondo com o primeiro livro que acho à mão.

- Mas, tu não tens razão de queixa, retorquiu Neto. As letras foram-te propícias, desde a tua estreia, no Maranhão, com $O$ Mulato. Surgiste com Minerva: armado e vitorioso.

- Pois sim, responde ele, encolhendo os ombros largos: vitorioso como Pyrrho, com seus elefantes de papel. O resto é que é. Escrever para quê? Para quem? Não temos público. Uma edição de dois mil exemplares leva anos a esgotar-se e o nosso pensamento, por mais original e ousado que seja, jamais se livrará no espaço amplo: voeja entre as grades desta gaiola estreita, que é a celebrada língua de nossos maiores. ${ }^{52}$

Apesar de ter escrito somente até os 37 anos, idade em que abraçou a carreira diplomática, poucos romancistas de sua geração alcançaram sua popularidade durante o período de produção. No entanto, esse sucesso não garantia ganhos significativos em dinheiro. Talvez por isso, ao longo de toda a sua produção literária, Aluísio Azevedo não tenha medido esforços para dar visibilidade às suas publicações. Para isso, anunciava seus lançamentos, inventando situações para aguçar a curiosidade do público e criar expectativas sobre o romance que logo viria a lume.

Conta Orna Messer Levin que, quando da publicação de $O$ mulato, o escritor redigiu uma crônica, publicada no jornal Pacotilha, na qual anunciava a chegada de um ilustre advogado, dr. Raimundo, protagonista do romance, em São Luís do Maranhão. Com esse expediente criou a existência de uma criatura puramente literária, mas as pessoas à época chegaram a acreditar que o tal dr. Raimundo fosse real.

\footnotetext{
${ }^{52}$ Cf. MENEZES, Raimundo de. Aluísio Azevedo, uma vida de romance. São Paulo: Livraria Martins Editora, 1958, p. 183-4.
} 
Os planos promocionais assinalam a luta incansável que travou pelo reconhecimento da literatura como produto de mercado. O senso estratégico com relação ao efeito publicitário e ao impacto das mensagens ressalta o despertar de uma consciência sensível à mercantilização do trabalho intelectual dentro de uma sociedade vinculada ao sistema escravista, na qual a manutenção do artista dependia fortemente do apoio governamental. ${ }^{53}$

Concordamos com a estudiosa, mas acrescentamos que o esforço do autor em divulgar a própria obra vinha também da clara consciência que tinha sobre as precárias condições de produção e divulgação da literatura à época. É o que podemos deduzir a partir de suas próprias palavras a esse respeito:

Não, o povo não tem culpa. O culpado sou eu, que quis realizar o absurdo de viver das letras em um país de analfabetos. Aqui há um pequeno grupo de pedantes, que leem autores franceses, há gente do comércio que lê a tabela do câmbio e a pauta da Alfândega, o resto é ignaro. Já agora continuarei a escrever, porque não sei fazer outra coisa. Se eu não tivesse abandonado, com desprezo, os tamancos e a vassoura de marçano, seria hoje um conceituado capitalista, com prédios, família, talvez título, e uma adega. Sou romancista, expoente da cultura brasileira, e não tenho crédito para uma ceia de iscas. [...] Eu ainda acabo com uma carrocinha como o homem dos abacaxis e das melancias, correndo essas ruas com os meus romances, apregoando-os aos berros. ${ }^{54}$

Fato é que Aluísio Azevedo não só foi um dos primeiros a ver a produção literária como produto de mercado, como "o único de sua geração que considerava seu trabalho de romancista como uma atividade principal e quase exclusiva". 55

Como vimos, três edições de $O$ homem esgotaram-se em meses, em 1888. Favoreceram a publicidade em torno da obra, alguns expedientes promocionais, como

\footnotetext{
${ }^{53}$ LEVIN, Orna Messer. Aluísio Azevedo romancista. In: Aluísio Azevedo. Ficção Completa, vols. I e II. Rio de Janeiro: Nova Aguilar, 2005, p. 29. (Org.). Aluísio Azevedo. Ficção Completa. v. I. Rio de Janeiro: Nova Aguilar, 2005, p. 25.

${ }^{54}$ AZEVEDO, Aluísio. Introdução. In: Girândolas de amores. São Paulo: Livraria Martins Editora, 1960.

${ }^{55}$ MÉRIAN, Jean-Yves. Aluísio Azevedo, vida e obra (1857-1913): O verdadeiro Brasil do século XIX. Rio de Janeiro: Espaço e Tempo, 1988, p. 416.
} 
anunciar o romance na Gazeta da Tarde, onde trabalhava; organizar uma conferência pública, em que trechos do romance foram lidos por Coelho Neto para um auditório lotado, e a adaptação do romance para o teatro. As mesmas técnicas promocionais foram utilizadas quando da publicação de $O$ cortiço. Mérian reitera que a notoriedade de $O$ homem foi determinante para que, em seguida, o escritor assinasse com a Garnier contrato para reedição de $O$ mulato, $O$ Coruja e Casa de pensão. ${ }^{56}$

No entanto, a despeito de todos os expedientes usados por Aluísio e os amigos para divulgar suas obras e do sucesso de vendas, os ganhos do autor estavam longe do que conseguia, por exemplo, seu irmão Artur Azevedo com as peças teatrais. ${ }^{57}$

\subsection{Uma escrita empenhada}

Aluísio Azevedo produziu sua obra no momento em que o Brasil passava por grandes transformações. No campo da política dava-se a passagem do regime monárquico para o republicano; na área econômica, o trabalho do negro escravizado era paulatinamente substituído pela mão de obra assalariada, sobretudo dos imigrantes. Essas mudanças refletiam fortemente no quadro social e podem ser percebidas em muitas passagens de seus textos.

Na obra Literatura como missão, em que Nicolau Sevcenko parte da literatura de Euclides da Cunha e Lima Barreto para traçar um panorama histórico e cultural no Brasil da Belle Époque, há significativas reflexões sobre a produção intelectual dos escritores no último quartel do XIX. Segundo ele, "A palavra de ordem da então 'geração modernista de 1870' era condenar a sociedade 'fossilizada' do Império e pregar as grandes reformas redentoras: 'a abolição', 'a república', a 'democracia'. O engajamento se torna a condição ética do homem de letras". ${ }^{5}$

\footnotetext{
${ }^{56}$ MÉRIAN, Jean-Yves. Aluísio Azevedo, vida e obra (1857-1913): O verdadeiro Brasil do século XIX. Rio de Janeiro: Espaço e Tempo, 1988, p. 441.

${ }^{57}$ Idem, p. 445.

58 SEVCENKO, Nicolau. Literatura como missão: tensões sociais e criação cultural na Primeira República. São Paulo: Companhia das Letras, 2003, p. 97.
} 
Como vimos até aqui, Aluísio Azevedo integrava esse grupo de escritores e, por meio do texto ficcional ou jornalístico, defendia ideias abolicionistas, liberais e republicanas. Todavia, segundo o historiador, foi justamente essa predisposição temática e política, assumida por esses pensadores e artistas brasileiros, que permitiu o florescimento de "um ilimitado utilitarismo intelectual tendente ao paroxismo de só atribuir validade às formas de criação e reprodução cultural que se instrumentalizassem como fatores de mudança social". ${ }^{59}$ Para alcançar essa meta, a cultura europeia gozava da vantagem de ser o único padrão de pensamento que tinha validade como modelo para iniciativas de modernização de sociedades tradicionais, como era então o caso da brasileira naquele momento.

Ainda segundo Nicolau Sevcenko, para intelectuais como Tobias Barreto e Joaquim Nabuco, em uma situação reduzida ao servilismo político, como no caso do Brasil, era preciso "construir a nação e remodelar o Estado, ou seja, modernizar a estrutura social e política do país". ${ }^{60}$ Pois foram esses os parâmetros que pautaram a produção intelectual do período. No entanto, além desse anseio pelo reformismo, baseado no liberalismo e no cientificismo, havia outra questão que, certamente, no caso do Brasil, era bastante peculiar:

Tratava-se do temor obsessivo extremamente difundido e sensível em todo tipo de escritor, de que o Brasil viesse a sofrer uma invasão das potências expansionistas, perdendo sua autonomia ou parte de seu território. Espantados com o ritmo delirante com que grandes potências procediam à retaliação do globo terrestre, com os cistos de imigrantes inassimiláveis que se formavam e cresciam em seu território, e com o próprio vazio demográfico de amplos espaços do país que assumiam a afeição de uma terra de ninguém. ${ }^{61}$

No entanto, a despeito dos embates travados por esses intelectuais e artistas nos jornais, livros ou cátedras - tanto em prol da Abolição, ocorrida em maio de 1888, como em defesa da República -, não foram aceitos como líderes da nação para as reformas que defendiam. Tampouco houve participação popular em tais movimentos,

59 SEVCENKO, Nicolau. Literatura como missão: tensões sociais e criação cultural na Primeira República. São Paulo: Companhia das Letras, 2003, p. 99.

${ }^{60}$ Idem, p. 103.

${ }^{61}$ Idem, p. 104. 
malgrado os esforços por eles empreendidos. No caso da Abolição da escravatura, a participação limitou-se aos festejos, nada foi feito concretamente para a melhoria de vida dos libertos, como bem nos mostra Emília Viotti:

Realizada no plano político-parlamentar pelas categorias dominantes, mais interessadas em liderar a sociedade do ônus da escravidão do que resolver os problemas do negro, a Abolição significou apenas uma etapa jurídica na emancipação do escravo que, a partir de então, foi abandonado à sua própria sorte e se viu obrigado a conquistar por si sua emancipação real. [...] A Abolição não significou a destruição imediata da ordem tradicional. O país continuou predominantemente agrário, apoiando-se na exportação de produtos tropicais [...] O negro marcado pela herança da escravidão, não estando preparado para concorrer no mercado de trabalho e tendo que enfrentar toda sorte de preconceitos, permaneceu marginalizado. ${ }^{62}$

Mesmo por ocasião da Proclamação da República, ocorrida um ano e meio depois da Abolição, a participação popular não correspondeu ao idealizado pela maioria dos intelectuais e escritores da época. Emília Viotti apresenta detalhada retrospectiva das diferentes abordagens. Desde as análises feitas no calor da hora, tanto por monarquistas como por republicanos, passando pelas realizadas por Oliveira Vianna, na década de 1920, e pela contribuição de marxistas como Caio Prado e Nelson Werneck, até chegar à visão de alguns de seus contemporâneos.

Logo no alvorecer da República, os monarquistas consideravam que a queda do regime fora resultado de um golpe militar e não reconheciam as falhas da Monarquia. Como afirma Emília Viotti, "A República fora fruto do descontentamento e da indisciplina dos militares que se aliaram aos fazendeiros ressentidos com a abolição da escravatura". ${ }^{63}$ Já para os republicanos, a proclamação da República foi uma reação necessária aos vícios do regime monárquico, como a vitaliciedade do Senado, a centralização do poder e as fraudes eleitorais. "Ao proclamar a República, os militares seriam os intérpretes do povo. Ao partido republicano e ao Exército cabiam as glórias

\footnotetext{
${ }^{62}$ COSTA, Emília Viotti da. Da senzala à colônia. São Paulo: Editora da Unesp, 1997, p. 529-30.

${ }^{63}$ COSTA, Emília Viotti da. Da Monarquia à República. São Paulo: Editora da Unesp, 1997, p. 449.
} 
do movimento."64 Havia também aqueles que, influenciados pelo positivismo, “consideraram a queda da Monarquia uma decorrência natural do processo histórico: estando o regime monárquico historicamente condenado, a República era o desenlace natural dos acontecimentos". ${ }^{65}$

O evidente nas três abordagens é a tendência a dar grande importância à atuação de personagens: de um lado Lopes Trovão e Silva Jardim, que defendiam uma revolução popular como único caminho para instaurar a República, e por outro, as ideias defendidas por Quintino Bocaiúva e seus companheiros, que queriam uma transição pacífica da Monarquia para a República.

Neste cenário, surge Marechal Deodoro da Fonseca, saído vitorioso da Guerra do Paraguai. Estimulado por Rui Barbosa, Benjamim Constant e Quintino Bocaiúva, e insuflado pela insatisfação militar em relação às medidas coercitivas no que dizia respeito à liberdade de expressão, ele liderou a tropa que marchou até o Ministério da Guerra e instaurou a República. Em torno dele, reuniam-se veteranos da Guerra do Paraguai, que, segundo Boris Fausto, ajudaram "a derrubar a Monarquia para salvar a honra do exército e não possuíam uma visão elaborada da República, a não ser a de que o Exército deveria ter um papel maior do que o desempenhado no Império" 66

Segundo Emília Viotti, na década de 1920, os historiadores começaram a atribuir aos próprios monarquistas a responsabilidade pelo sucedido. Mesmo estudiosos do porte de Oliveira Vianna não percebem que o processo de desagregação do sistema escravagista no Brasil estava intimamente relacionado "com as mudanças ocorridas na estrutura social e econômica do país durante a segunda metade do século XIX, ao dizer que o imperador foi o grande centro irradiador das forças na aceleração da marcha abolicionista". 67

A partir da década de 1930, historiadores como Caio Prado Jr. e Nelson Werneck, em uma abordagem de enfoque marxista, defendem que a Proclamação da República foi resultado das profundas transformações que vinham ocorrendo tanto no

\footnotetext{
${ }^{64}$ COSTA, Emília Viotti da. Da Monarquia à República. São Paulo: Editora da Unesp, 1997, p 449.

${ }^{65}$ Ibidem, p. 449.

${ }^{66}$ FAUSTO, Boris. História concisa do Brasil. São Paulo: Edusp, 2010, p. 140.

${ }^{67}$ COSTA, Emília Viotti da. Da Monarquia à República. São Paulo: Editora da Unesp, 1997, p. 441.
} 
âmbito econômico como social. O advento teria sido resultado de profundas transformações que vinham se operando no país. Contribuíram para isso: a decadência das oligarquias tradicionais, ligadas à terra, a Abolição, a imigração, o processo de industrialização e urbanização, o antagonismo entre zonas produtoras e a campanha pela federação. Nessa perspectiva:

O movimento resultou da conjugação de três forças: uma parcela do Exército, fazendeiros do Oeste Paulista e representantes das classes médias urbanas que, para a obtenção dos seus desígnios, contaram indiretamente com o desprestígio da Monarquia e o enfraquecimento das oligarquias tradicionais. ${ }^{68}$

Fato é que, apesar do esforço dos escritores e intelectuais da chamada geração de 1870 , as grandes reformas por eles idealizadas passaram ao largo de seus objetivos. As palavras de ordem daqueles que se consideravam "os mosqueteiros intelectuais", em prol das grandes reformas, como abolição, república, democracia e reforma social perderam o sentido com o advento da Abolição (1888) e da Proclamação da República (1889), resultando em uma experiência traumática para a grande maioria deles.

Talvez alguns dados numéricos sobre a parca influência das ideias dos diferentes grupos de republicanos, postuladas em veículos como jornais e livros, que pressupunham um público leitor, possam explicar certa frustração dessa geração. Aqueles que, em decorrência do desencantamento experimentado logo no alvorecer da República, foram chamados por Sevcenko de "paladinos malogrados". 69

Não é novidade que no Brasil do último quartel do século XIX o analfabetismo grassava. Apenas algumas cidades contavam com escolas públicas, e em número insuficiente para atender a população local. Nas áreas rurais, apenas os filhos de fazendeiros mais esclarecidos tinham acesso rudimentar aos conhecimentos escolares, ensinados geralmente por um preceptor. Ainda que não possamos nos deter demoradamente na questão da educação no Brasil nesse período, pois fugiríamos do âmbito central de nossa pesquisa, vale apresentar a súmula de alguns números. Esses

\footnotetext{
${ }^{68}$ COSTA, Emília Viotti da. Da Monarquia à República. São Paulo: Editora da Unesp, 1997, p. 489.

69 SEVCENKO, Nicolau. Literatura como missão: tensões sociais e criação cultural na Primeira República. São Paulo: Companhia das Letras, 2003, p. 107.
} 
dados são importantes não só para que se entenda a pouca difusão das ideias postuladas pelos escritores e intelectuais da chamada "geração de 1870" em prol da Abolição e da República, como também para compreender algumas propostas defendidas por Aluísio Azevedo no livro $O$ Coruja, como veremos posteriormente.

Segundo Hélio de Seixas, “em 1872, apenas 18,6 \% da população livre e 15,7\% da população total, incluindo os escravos, sabiam ler e escrever". ${ }^{70}$

Marisa Midori Deaecto também apresenta dados expressivos a respeito da escolarização à época, alertando para o fato de que, a partir de 1851, as decisões do setor educacional ficam concentradas nas mãos de um Inspector-Geral provincial:

Como resultado desse processo de provincianização das decisões do ensino observa-se que, em 1876, as escolas públicas se concentravam na região com maior potencial econômico e participação política no país, ou seja, no Centro-sul (atual Sudeste); Minas Geias (703), São Paulo (638) e Rio de Janeiro (562) detinham $42,9 \%$ de um total de 4430 escolas públicas, franqueadas para um contingente de 138.615 alunos espalhados pelo vasto território brasileiro. ${ }^{71}$

A situação não mudou muito nos anos seguintes, de acordo com informações de 1889, quando se publicam dados a respeito da cidade do Rio de Janeiro:

Em 1888 tínhamos 91 escolas públicas em que se matricularam 9.021 alunos, dos quais apenas 7.000 talvez as frequentaram. A capital do Rio de Janeiro tem seguramente 400.000 habitantes, e, portanto, uma população escolar que não pode ser inferior a 70.090 crianças. Demos de barato que 13.000 frequentaram as escolas particulares e 10.000 aprenderam a ler em casa de seus pais ou tutores. Conclusão: houve ainda 40.000 analfabetos, o que é assustador e vergonhoso para um país que se preza culto. ${ }^{72}$

Para agravar o quadro, havia o grande contingente de ex-escravizados, deixados à

\footnotetext{
${ }^{70}$ GUIMARÃES, Hélio de Seixas. Os leitores de Machado de Assis: O romance machadiano e o público de literatura no século 19. São Paulo: Nankin/Edusp, 2004, p. 66.

${ }^{71}$ DEAECTO, Marisa Midori. O império dos livros. São Paulo: Edusp, 2011, p. 211.

${ }^{72}$ Gazeta de Notícias, Rio de Janeiro, 31 maio 1890. Apud: MÉRIAN, Jean-Yves. Aluísio Azevedo, vida e obra (1857-1913): O verdadeiro Brasil do século XIX, Rio de Janeiro: Espaço e Tempo, 1988, p. 337.
} 
própria sorte, pois sabemos que, em seu único artigo, a Lei Áurea não previa quaisquer medidas para integrá-los à sociedade. O grande número de imigrantes e o êxodo rural aumentavam ainda mais a quantidade de crianças em fase escolar no Rio de Janeiro.

A abolição e a crise da economia cafeeira que se lhe seguiu - que significou o golpe de misericórdia aplicado na grande lavoura do Vale do Paraíba carioca - desencadeou uma enorme mobilização (85.547 pessoas) da massa urbana outrora presa àquela atividade e que ali, com o já volumoso contingente de escravos recémlibertados, em 1872 chegara a constituir $18 \%$ (48.939 pessoas) da população total da capital do império. Vêm somar-se a essa multidão os sucessivos magotes de estrangeiros, que a previdência dos proprietários pressagiosos da Abolição e as vicissitudes europeias arrastaram para o porto do Rio, os quais somaram 70.298 pessoas de 1890 a $1900 .^{73}$

Apesar do grande número de indivíduos em fase escolar que poderiam ser encontrados nesse contingente, apenas dois colégios merecem destaque na cidade do Rio de Janeiro da época. O Colégio Abílio, fundado e dirigido por Abílio César Borges, em 1871, e o célebre D. Pedro II, ambos frequentados por filhos de pais abastados, ainda que o segundo fosse patrocinado pelo imperador desde $18377^{74}$

Vale lembrar ainda que as moças, mesmo as nascidas em famílias da alta sociedade, eram geralmente educadas em casa por uma preceptora, não raro francesa. A exemplo do que é retratado no romance $O$ Coruja, na figura da personagem Branca.

\footnotetext{
73 SEVCENKO, Nicolau. Literatura como missão: tensões sociais e criação cultural na Primeira República. São Paulo: Companhia das Letras, 2003, p. 72.

${ }^{74}$ Com relação ao ensino superior, diferentemente do que ocorrem nos países de colonização espanhola, a primeira instituição de ensino superior da América portuguesa, a Fameb (Faculdade de Medicina da Bahia) foi fundada somente após a chegada da família real no Brasil, em 1808. Sérgio Buarque de Holanda nos mostra os números de Universidades fundadas na América Espanhola e a diferença é realmente alarmante. "O afã de fazer das novas terras mais do que simples feitorias comerciais levou os castelhanos, algumas vezes, a começar pela cúpula a construção do edifício colonial. Já em 1538, cria-se a Universidade de São Domingos. A de São Marcos, em Lima, com os privilégios, isenções e limitações da de Salamanca, é fundada por cédula real de 1551, vinte anos apenas depois de iniciada a conquista do Peru por Francisco Pizzaro. Também de 1551 é a da Cidade do México, que em 1553 inaugura seus cursos. Outros institutos de ensino superior nascem ainda no século XVI e nos dois seguintes, de modo que, ao encerrar-se o período colonial, tinham sido instaladas nas diversas possessões de Castela nada menos de 23 universidades, seis das quais de primeira categoria (sem incluir as do México e Lima). Por esses estabelecimentos passaram, ainda durante a dominação espanhola, dezenas de milhares de filhos da América que puderam, assim, completar seus estudos sem precisar transpor o oceano." Raízes do Brasil. Sérgio Buarque de Holanda. São Paulo: Companhia das Letras, 2004, p. 123.
} 
A opinião de José Veríssimo sobre os que concluíam o ensino superior também não era das mais otimistas:

Entre nós contam-se as casas, a não ser a de algum médico que tem os livros de medicina, e a de algum advogado que tem os seus livros de direito, que possuam meia dúzia de volumes. E a respeito de "homens formados", direi de passagem que, segundo me têm comunicado os livreiros desta capital, são eles os que menos livros compram. Os doutores parece que têm horror à letra redonda. ${ }^{75}$

A impressão de Aluísio Azevedo, poucos anos depois da Proclamação da República, também não era das mais alentadoras, pelo menos é o que nos deixa perceber depoimento do escritor de 1893:

Depois da bancarrota, o público brasileiro divide-se apenas em duas ordens; a dos que tudo perderam e a dos que tudo ganharam. Os primeiros choram de fome, e os segundos tremem de medo pela sua riqueza mal adquirida. Uns se escondem para ocultar a miséria; outros para fugir à justiça... Um belo carnaval! E ninguém lê livros. ${ }^{76}$

Antonio Candido, na obra Formação da literatura brasileira, defende a ideia de que a literatura brasileira propriamente dita só se configurou no decorrer do século XVIII, no Arcadismo.

Suponhamos que, para se configurar plenamente como sistema articulado, ela dependa do triângulo: 'autor-obra-público' em interação dinâmica, e de uma certa continuidade da tradição. Sendo assim a brasileira não nasce, é claro, mas se configura no decorrer do século XVIII. ${ }^{77}$

E se isso só ocorre nesse período, é porque, a despeito da importância de autores anteriores, como Antonio Vieira e Gregório de Matos, só na Arcádia Ultramarina tínhamos um grupo de escritores com um projeto claro sobre o seu fazer literário; as

\footnotetext{
${ }^{75}$ VERÍSSIMO, José. Literatura e homens de letras (1883). Estudos Brasileiros, $1^{\mathrm{a}}$ série, Belém, 1889, p. 135.

${ }^{76}$ HALLEWELL, Laurence. O livro no Brasil (Sua história). São Paulo: T.A. Queiroz/Edusp, 1885, p. 183.

${ }^{77}$ CANDIDO, Antonio. Formação da literatura: Momentos decisivos. Rio de Janeiro: Ouro sobre Azul: 2006, p. 25.
} 
possibilidades de edição e publicação - ainda que os livros fossem impressos em Portugal, já que as normas impostas pela metrópole impediam que fossem produzidos na colônia; e, sobretudo, a haste fundamental desse tripé: um público receptor. Neste caso, uma elite produzida pelas riquezas retiradas das entranhas das minas em ouro. No entanto, o que poderíamos dizer desse tripé cerca de 100 anos depois do Arcadismo?

Por certo nossa literatura já havia acumulado importante corpus literário, com nomes de expressividade desde os árcades. Significativa também era a produção dos intelectuais, que tinham ampla participação nos jornais da época. Quanto ao público receptor, vimos que os dados sobre a escolaridade não eram os mais desejáveis. Mas o que dizer a respeito dos mecanismos transmissores?

Os contratos estudados revelam que uma edição geralmente era de 500 a 1.000 exemplares. Os romances mais conhecidos na atualidade como clássicos da literatura brasileira, publicados entre 1800 e 1895, com exceção de obras de Machado de Assis e Aluísio Azevedo, ${ }^{78}$ não foram reeditados naquele período.

Soma-se a isso o fato de que não se pagava direito autoral para os romances franceses e portugueses vendidos no país: "As obras de escritores europeus eram traduzidas, adaptadas e difundidas no Brasil sem que estes recebessem o menor direito autoral". ${ }^{79}$ Essa prática dificultava ainda mais a edição e difusão de obras de escritores nacionais, pois os poucos editores e donos de jornais davam prioridade às traduções e adaptações, que lhes saíam muito mais baratas. Portanto, não era incomum que os próprios escritores bancassem as primeiras edições de suas obras, que no caso raramente passavam de 300 exemplares. Não é preciso dizer que isso dificultava sobremaneira a difusão do livro.

Além disso, não havia nenhuma legislação que garantisse aos escritores brasileiros direito sobre a produção e difusão de seus livros, que tinham de contar com leitores por demais expostos à literatura estrangeira, sobretudo francesa e portuguesa, para escolher as próprias leituras. Em resumo, os escritores brasileiros do final do XIX

\footnotetext{
${ }^{78}$ Com exceção de Uma lágrima de mulher, todos os romances de Aluísio Azevedo foram reeditados durante 1881-1896. Ver MÉRIAN, Jean-Yves. Aluísio Azevedo, vida e obra (1857-1913): O verdadeiro Brasil do século XIX, Rio de Janeiro: Espaço e Tempo, 1988, p. 433.

${ }^{79}$ Idem, p. 362.
} 
tinham visíveis dificuldades de viver da própria pena.

Em 1879, o português Pinheiro Chagas endereça carta-aberta a D. Pedro II para denunciar os abusos dos editores e donos de jornais no Brasil quanto ao não pagamento do direito autoral. Essa carta suscitou importante debate entre autores brasileiros. Aluísio Azevedo, então no Maranhão, escreveu sobre os debates travados de 20 a 23 de setembro de 1880 em um congresso literário, organizado em Lisboa, para discutir essas questões. Esses artigos foram veiculados no Pacotilha. ${ }^{80}$ No entanto, somente em 1889 foi assinado um contrato entre Brasil e Portugal para garantir os direitos sobre obras de além-mar publicadas por aqui.

Dentre os brasileiros que lutaram nessa frente, merece destaque Pardal Male. Segundo Lajolo e Zilberman, "Ele dedicou-se à questão dos direitos autorais, por cujo reconhecimento e remuneração lutou, valendo-se dos artigos redigidos em $1890 \mathrm{em}$ jornais cariocas, como o Diário de Notícias e a Gazeta de Notícias". ${ }^{81}$

Em 1883, um grupo liderado por Sílvio Romero e Araripe Júnior propôs a criação da "Associação dos homens de letras do Brasil", mas o projeto não vingou. Tentou-se, em 1890, a fundação da "Sociedade dos Homens de Letras", tendo como arautos Machado de Assis, Aluísio Azevedo, Pardal Male, entre outros, mas o projeto também não saiu do papel. No entanto, quatro anos depois, a Câmara dos Deputados envia ao Senado uma proposição tratando da regulamentação dos direitos autorais, que depois de muitos trâmites converte-se em lei bem mais adiante, em 1898.

Entretanto, apesar desses avanços, a relação entre escritores e editores continuou submetida às tácitas leis da oferta e da procura, sobretudo porque os escritores brasileiros continuavam a disputar lugar com os europeus, principalmente, franceses. Como bem ilustra Mérian, a respeito de Aluísio:

Em 1892, Aluísio Azevedo está com um livro de contos pronto há um ano e meio com editor da Montalverde. Este livro não é publicado em razão da concorrência de traduções de obras francesas que são mais rentáveis. Dois anos mais tarde, o mesmo fenômeno se repete para o

\footnotetext{
${ }^{80}$ MÉRIAN, Jean-Yves. Aluísio Azevedo, vida e obra (1857-1913): O verdadeiro Brasil do século XIX. Rio de Janeiro: Espaço e Tempo, 1988, p. 366-7.

${ }^{81}$ LAJOLO, Marisa e ZILBERMAN, Regina. O preço da leitura. São Paulo: Ática, 2000, p. 136.
} 
Livro de uma sogra. A editora Magalhães \& Cia parecia estar mais interessava em publicar obras de Zola. ${ }^{82}$

Diante desse panorama desastroso, não é difícil entender por que, de “mosqueteiros intelectuais", esses homens de letras, da geração de 1870, passaram à trágica situação de "Paladinos malogrados":

[...] dotados de um equipamento intelectual que era ele próprio fruto da situação de crise que viviam, dificilmente esses intelectuais poderiam aquietar as perplexidades que os enleavam. Muito menos ainda puderam ser aceitos como líderes e condutores da nação no sentido das reformas que propalavam. Daí o destino particularmente trágico de paladinos malogrados que a história lhes reservou. ${ }^{83}$

\subsection{As atividades consulares}

Recapitulando, durante os quase 17 anos em que se dedicou à literatura, Aluísio Azevedo escreveu 11 romances, uma novela policial, várias peças de teatro, duas antologias de contos e inúmeros artigos em jornais e revistas.

Desgostoso com o pouco rendimento que obtinha com a venda de seus livros, resolveu prestar exames para ingressar na carreira diplomática, no intuito de ter mais tempo para dedicar-se à escrita criativa.

Em algumas cartas escritas por Aluísio Azevedo aos amigos, ele deixa transparecer que o excesso de trabalho burocrático não lhe permite o tempo necessário para dedicar-se, como gostaria, à literatura:

[...] do ofício de cônsul só os ossos têm cabido em partilha, apesar de habilitado pela respeitável congregação examinadora da Secretaria

\footnotetext{
${ }^{82}$ MÉRIAN, Jean-Yves. Aluísio Azevedo, vida e obra (1857-1913): O verdadeiro Brasil do século XIX. Rio de Janeiro: Espaço e Tempo, 1988, p. 383.

${ }^{83}$ SEVCENKO, Nicolau. Literatura como missão: tensões sociais e criação cultural na Primeira República. São Paulo: Companhia das Letras, 2003, p. 107.
} 
para cônsul de carreira não honorário - um susto e uma carreira é que parece o que fizeram comigo. (Carta dirigida de La Plata a Lúcio de Mendonça, em 26 de dezembro de 1900)

Os consulados do Brasil não são como os de Portugal, por exemplo, quando nosso governo faz algum cônsul, quer para aí o trabalhinho ou reclama que lhe despejem o lugar. Isso não é como era o consulado de Eça de Queirós em Bristol, para onde ele foi mandado, não para desunhar em ofícios e legalizações de papelada de navios, mas para ter tempo folgado e farto para escrever seus adoráveis livros. (Carta enviada para Figueiredo Pimentel, de Cardiff, datada de 5 de julho 1905) $)^{84}$

Rodrigo Octavio acredita que a suposta improdutividade literária deveu-se ao fato de o escritor ter perdido o contato com a realidade brasileira, que era a fonte de inspiração para suas criações:

Eu não insisti na minha pergunta indiscreta; mas, o romancista, já tão inteiramente senhor de si, voltou ao caso, e explicou longamente, particularizadamente, como quem quer achar argumentos para se convencer a si próprio. Queria trabalhar, por certo; tinha ânsia de produzir, mas faltava-lhe a atmosfera, a paisagem, o espetáculo. Se fora um poeta, faria versos em que falaria a saudade que tinha da terra; mas era senão um pintor e faltava-lhe o modelo. Estava estudando, acumulando elementos espirituais, mas que só se poderiam materializar no livro, transformar-se no romance, quando voltasse a viver em sua terra com sua gente. ${ }^{85}$

Fato é que Aluísio Azevedo realmente jamais voltou a escrever com o furor que o impulsionou durante os anos de intensa produção, mas deixou uma coletânea de impressões de viagens, escritas durante sua estada em Yokohama, que foram publicadas somente em 1984 , sob o título $O$ Japão. ${ }^{86}$

Sua correspondência com Afrânio Peixoto também registra desejo não

\footnotetext{
${ }^{84}$ AZEVEDO, Aluísio. Touro negro. São Paulo: Livraria Martins Editora, 1961, p. 137 e 156.

${ }^{85}$ OCTAVIO, Rodrigo. Minhas memórias dos outros. Rio de Janeiro: Civilização Brasileira, 1979, p. 91. ${ }^{86}$ AZEVEDO, Aluísio. Japão. Apresentação e comentários de Luiz Dantas. São Paulo: Roswitha Kempf editores. Inicialmente o título previsto pelo escritor para essa obra foi Agonia de uma raça.
} 
consumado de escrever um romance sobre uma personagem misto de Dom Quixote e Antônio Conselheiro, que, movido pela fé, acabaria sendo martirizado.

Por sua causa, só com aquelas palestras lá em casa sobre literatura, têm-me aparecido tais pruridos de trabalhar, que começo a ver na execução daquele livro que the falei uma necessidade imperiosa, começo a sentir que um carnegão quer ser exprimido e já não resisto ao desejo de tomar notas, desde que as ideias se apresentam.

(Carta enviada de Nápoles, datada de 3 de dezembro de 1909.) ${ }^{87}$

Tal correspondência documenta ainda o envio de livros por Afrânio Peixoto para subsidiar as pesquisas de Aluísio, mas não encontramos quaisquer outras informações sobre a produção dela nos livros pesquisados. De qualquer forma, fica a certeza de que a angústia da não escrita rondava sempre o prolífico romancista que fora um dia.

Como cônsul, Aluísio Azevedo trabalhou em Vico, La Plata, Salto Oriental, Yokohama, Cardiff, Nápoles, Assunção e Buenos Aires, onde faleceu, em 21 de janeiro de 1913, de uma crise cardíaca, em consequência de sequelas deixadas por um atropelamento, sofrido em agosto de 1912.

Nossa tentativa ao escrever essa nota biográfica do escritor maranhense, com foco em sua formação intelectual, artística e política, foi buscar compreender um pouco do contexto da produção, para que pudéssemos melhor localizar a importância da obra que escolhemos para estudo. Esperamos que nosso objetivo tenha sido alcançado.

\footnotetext{
${ }^{87}$ AZEVEDO, Aluísio. Touro negro. São Paulo: Livraria Martins Editora, 1961, p. 167.
} 


\section{CAPÍTULO 2 - O CORUJA: DA PRODUÇÃO À RECEPÇÃO}

O romance por nós escolhido para estudo foi pouco publicado nas últimas décadas e até o momento não despertou grande interesse na crítica. Diante desse quadro, decidimos iniciar este capítulo com o resumo da obra, por acreditar que esse procedimento facilitará a análise a ser realizada em capítulos posteriores.

Apresentaremos, em seguida, algumas informações sobre a possível gênese do romance, alguns dados sobre o jornal $O$ Paiz, no qual o romance foi publicado em 1885, e o levantamento sobre as edições da obra.

Para finalizar o capítulo, faremos uma revisão da crítica sobre a obra de Aluísio Azevedo, mas com ênfase no que foi escrito sobre o romance $O$ Coruja. Em certa medida, esse percurso será diacrônico, pois tentaremos mostrar os avanços em torno das discussões sobre a obra aluisiana, a despeito de haver certa tendência à repetição das ideias postuladas pelos primeiros críticos, como veremos mais adiante.

\subsection{Resumo do romance}

O livro é estruturado em três grandes partes, subdivididas em capítulos bem curtos, provavelmente para atender à demanda folhetinesca. As partes não são nomeadas e são usados números para delimitar os capítulos.

\section{Primeira parte}

A narrativa tem início com informações sobre André, cuja mãe morre quando ele tem 4 anos. Feio e casmurro, o menino é criado por um padre até a idade de 10 anos, quando é enviado para um colégio interno. Aí já mostra sua grande vocação para o trabalho, quer seja ajudando o jardineiro, quer seja organizando os tomos da biblioteca. É nesse lugar que conhece Teobaldo, "menino de 12 anos, muito bonito, elegante e criado com mimo. Falava melhor o inglês e o francês do que sua própria língua, porque 
estivera mais tempo em Londres do que no Brasil. Era detestado pelos colegas do colégio, pois sentia-se a uma légua de distância o hábito de mandar e ser obedecido". ${ }^{8}$

É justamente essa postura que desencadeia uma briga no pátio do colégio, durante a qual Teobaldo é defendido por André, mais conhecido por Coruja, devido a sua fealdade e seu jeito taciturno. Ambos acabam por ficar de castigo. É nesse espaço de "cárcere" que a amizade tem início: Teobaldo não só faz questão de ficar de castigo na companhia daquele que o defendera, como divide com ele as deliciosas iguarias de uma cesta, enviada pela mãe aos cuidados de Caetano, servidor fiel que o acompanhará até o final da trama.

Nessa parte do romance, o narrador conta também como se deu o enriquecimento do pai de Teobaldo, Emílio de Albuquerque. Este era filho de fidalgo português, dos que vieram para o Brasil em companhia do príncipe regente. Destinado desde cedo às armas, integrou a guarda de honra de Dom Pedro I, perdeu suas ilusões na guerra da Cisplatina $^{89}$ e foi viver na Europa, de onde só voltou no período da Regência. Casouse, enviuvou. Depois, foi para Diamantina em busca de pedras preciosas. Participou da Revolução dos liberais de $1842,{ }^{90}$ em Santa Luzia. Foi agraciado pelos favores de Teófilo Otoni, o que favoreceu o recebimento do título de barão de Palmar. Por acaso, travou conhecimento com um importante cafeicultor da Zona da Mata mineira, pai de Laura, sua futura esposa, que virá a ser a mãe de Teobaldo.

Essa espécie de digressão histórica dentro do romance nos ajuda a entender não apenas as origens de Teobaldo, mas também localizar histórica e geograficamente o romance, que começa em uma pequena cidade de Minas, não nomeada, onde nasce André, passando pelas fazendas de café do pai de Teobaldo, até a partida dos jovens para estudar na Corte.

\footnotetext{
${ }^{88}$ AZEVEDO, Aluísio. O Coruja. São Paulo: Livraria Martins Editora, 1963, p. 31.

${ }^{89} \mathrm{O}$ narrador refere-se aos movimentos armados promovidos pelos liberais em Minas Gerais e São Paulo contra as medidas centralizadoras impostas pelo Partido Conservador, que dominava o governo desde 23 de março de 1841.

${ }^{90} \mathrm{O}$ grande proprietário de terras e político Teófilo Otoni foi o chefe mais expressivo do movimento liberal em Minas Gerais. A revolução atingiu São João d'El Rei, São José e outras localidades do interior mineiro. A batalha decisiva foi a de Santa Luzia (ocorrida em agosto), na qual os revoltosos foram derrotados.
} 


\section{Segunda parte}

Nessa altura do romance, vamos encontrar os rapazes já no Rio de Janeiro, onde são recebidos pelo comerciante Sampaio. Este senhor, se tinha atenções para com Teobaldo, estas provinham sem dúvida dos rendimentos que o pai do jovem dava anualmente à casa comercial dele. É da boca de Sampaio que Teobaldo recebe as primeiras instruções sobre como se comportar na Corte e, sobretudo, o conselho de não se meter a "escrevinhador".

Teobaldo e André vão morar em uma casinha em Mata-cavalos. Uma vez instalados, é preciso que Teobaldo escolha o que estudar, e aí temos significativo diálogo entre os amigos, em que fica evidente a dificuldade do rapaz em escolher um caminho, o que pode ser resumido na frase dita por ele ao final dessa conversa: "Tudo me atrai; nada, porém, me prende!"91

André, por sua vez, que tanto estudara para os exames preparatórios para ter uma cadeira como professor, é reprovado, e torna-se professor particular para sobreviver. Enquanto isso, Teobaldo, que fora preparado pelo amigo, consegue finalmente matricular-se na escola de Medicina.

Procurado por d. Margarida - uma lavadeira que precisa de alguém para preparar sua filha, Inezinha, para ser professora -, André se dispõe a dar aulas de graça. Esse desprendimento leva a mãe a ver no rapaz um possível noivo para a insossa filha. André não estava apaixonado, mas acabou se afeiçoando à moça e, no fim de algum tempo, já não podia passar sem os calmos serões na casa de d. Margarida.

Por sua vez, Teobaldo acaba envolvendo-se com Ernestina, locadora da casa onde ele e o Coruja moram em Mata-cavalos. Ao mesmo tempo, o jovem se relaciona com a refinada Leonília, uma loureira, que conhecera no teatro.

Neste ínterim, duas notícias terríveis chegam ao mesmo tempo a Teobaldo: a morte da mãe e a falência do pai, que terá de hipotecar a fazenda para pagar as dívidas. É quando decide largar os estudos e procurar emprego. No entanto, acaba sendo dissuadido dessa ideia por André, que acredita que a carta de "doutor é a chave de

\footnotetext{
${ }^{91}$ AZEVEDO, Aluísio. O Coruja. São Paulo: Livraria Martins Editora, 1963, p. 75.
} 
todas as portas das boas posições sociais". ${ }^{92}$ Não conseguindo enfrentar a morte da esposa e a falência, Emílio comete suicídio. Teobaldo sente-se ainda mais perdido e sem perspectivas. André estimula o amigo a sair daquele estado de desânimo, mas o luto e a mágoa o absorvem por quase um ano. E ele nada mais faz além de comer o pouco dinheiro que o pai falido lhe deixara.

Teobaldo tenta empregar-se na imprensa, mas não consegue nenhuma colocação. Assim, era André quem provia todas as despesas da casa, do aluguel aos charutos do amigo, o que o levava a adiar o matrimônio com Inezinha. Além desse alentado casamento, o rapaz tinha dois outros projetos: montar um colégio reformador, sem castigos corporais e sem terrores, baseado nas ideias de Pestallozzi e Froebel, e "fazer um epítome da história do Brasil, em que se expusessem os fatos pela ordem cronológica". 93

Teobaldo acaba reencontrando Leonília, que voltara de uma longa viagem. Apaixonada, ela insiste em dedicar-se somente a ele, mas aquele amor que para ela seria uma virtude, para Teobaldo era uma depravação moral.

Ernestina reaparece depois da morte de seu amante, o sr. Almeida, exigindo que Teobaldo reassuma a relação com ela. No entanto, ao se dar conta do envolvimento do rapaz com Leonília e de sua proximidade com Branca - jovem de boa posição social com quem deseja casar-se -, resolve cometer suicídio. Não sem antes escrever uma carta-testamento, deixando todos os seus bens para Teobaldo. A despeito do remorso por ter destratado Ernestina horas antes do incidente, ele não se furta do direito de lançar mão do pecúlio por ela deixado e, três páginas adiante, o temos expiando a culpa nos lençóis de Leonília, para, em seguida, cortejar Branca, a filha do comendador.

Teobaldo não demora muito a gastar todo o dinheiro que lhe fora deixado por Ernestina e deseja realizar logo o casamento com Branca, mas Leonília ameaça confessar ao pai da noiva que fora sua amante. Para impedi-la, mais uma vez, André intervém e se desfaz de suas economias, estimulando a loureira a viajar e deixar Teobaldo em paz. Todavia, insuflado por Aguiar - primo de Branca, por quem é apaixonado -, o pai da jovem se opõe ao casamento. Os noivos fogem e conseguem se

\footnotetext{
${ }^{92}$ AZEVEDO, Aluísio. O Coruja. São Paulo: Livraria Martins Editora, 1963, p. 114.

${ }^{93}$ Idem, p. 121.
} 
casar, ajudados por André, que os abriga na casa de d. Margarida, além de emprestar dinheiro ao amigo para as despesas do casamento. Essa parte do romance termina com a morte do pai de Branca, fulminado por uma congestão cerebral ao saber do casamento da filha.

\section{Terceira parte}

A última parte da obra tem início com a apresentação da moradia do jovem casal em Botafogo. Estamos diante do mesmo sobrado de onde Branca fugira para casar-se com Teobaldo, mas uma grande transformação se dera naquele espaço. Toda a casa exalava luxo, dos jardins aos salões.

Por insistência de Teobaldo, André vai morar com o casal, mas só aceita o convite com a condição de ocupar o sótão. A esta altura, já tinha dinheiro suficiente para pagar as despesas de seu casamento com Inezinha, mas acaba tendo que socorrer d. Margarida, acometida pela varíola.

Aguiar continua a frequentar a casa de Branca e não perde de vista o objetivo de conquistar a prima, que se não foi por ele desposada, por certo haveria de ser sua amante. Chega a armar uma cilada para Teobaldo, emprestando-lhe a casa para um de seus encontros amorosos com a esposa de um eminente político, e faz com que Branca assista ao encontro às escondidas. Desde então, o amor da jovem esposa pelo marido transforma-se em mágoa, mas ela não cede ao assédio do primo.

Mais uma vez Teobaldo se vê em dificuldades financeiras, depois de perder dinheiro em aplicações no câmbio. Aguiar lhe empresta grande soma, livrando-o da falência. Leonília, de volta da Europa, vem a saber que o ex-amante está casado e feliz, e escreve uma carta anônima, afirmando que Branca o trai com um amigo.

Enquanto isso, Aguiar, que não conseguira seduzir a prima, ameaça protestar os títulos da dívida contraída por Teobaldo, caso ela não aceite tornar-se sua amante. Branca conta seus infortúnios a André, que, mais uma vez, paga as dívidas do amigo.

Ao ler a carta anônima, enviada por Leonília, Teobaldo acredita que Branca tem um amante. Ao voltar para casa, bem no momento em que ela, agradecida, abraça André, ele saca um revólver e atira no Coruja, acertando-lhe o calcanhar. 
Desfeitos os mal-entendidos, Teobaldo desculpa-se com o amigo. André, que investira todas as suas economias para ajudá-lo, não consegue manter o colégio que havia comprado - ficando ainda com um irremediável aleijão, resultante do tiro que recebera. Como se não bastasse, cansada de esperar, Inezinha casa-se com "Picuinha", um soldado raso alcoólatra, com quem terá dois filhos, antes que o marido, completamente corroído pelo álcool, seja internado em uma clínica.

Teobaldo envolve-se cada vez mais com a política. No entanto, seu sucesso político corresponde à sua decadência moral, e o leitor presencia seu envolvimento com a corrupção, as especulações e os vícios inerentes a algumas relações de poder. Em contrapartida, André continua a morar no sótão da casa de Teobaldo, de onde sai sempre pelos fundos, para não ser notado pelas pessoas de bem que frequentavam a casa do amigo, que agora, muito preocupado com sua reputação, paulatinamente vai dedicando menos tempo ao Coruja, de quem a proximidade passa a ser um estorvo.

O professor se via na obrigação moral de ajudar d. Margarida e Inezinha; por isso, depois da internação de Picuinha, aceita o convite para ocupar um quartinho na casa das duas mulheres. E toma para si toda a responsabilidade da família.

Branca percebe a derrocada moral do marido e se afasta cada vez mais dele. Todavia, ao vê-lo quase vender seus favores de ministro a especuladores ingleses, fala claramente tudo o que pensa a respeito de Teobaldo, que cai em profunda reflexão, que o leva a uma crise existencial.

Para mostrar ainda mais a decrepitude moral de Teobaldo, o narrador faz com que ele reencontre Leonília, que, ao vê-lo perambulando pela rua e não o reconhecendo, convida-o para entrar em sua casa. Todavia, quando a cortesã reconhece o ex-amante no suposto desconhecido, expulsa-o de sua casa.

Abandonado por todos, Teobaldo adoece e morre de hemoptise. Seu enterro foi suntuoso. De longe, André acompanhou o funeral até o cemitério. Assim que a população pôs-se em retirada, pôde finalmente aproximar-se da sepultura e chorar pela morte do amigo. 


\subsection{A suposta gênese do romance}

Ao estudar os romances-folhetins de Aluísio Azevedo, Jean-Yves Mérian indica o "sistema de gavetas", adotado pelo escritor, em que alguns folhetins são esboços dos romances. Foi o caso d' $O$ cortiço, no qual o pesquisador viu a retomada de temas tratados em Memórias de um condenado e Girândola de amores. Aponta também para o fato de alguns contos, como "Músculos e nervos" e "Folha roubada à carteira de uma viúva" terem sido retirados quase na íntegra dos dois folhetins supracitados. Para ele, algumas passagens desses folhetins são verdadeiros contos. ${ }^{94}$

Em concordância com esse caminho interpretativo de Mérian, percebemos que o esboço de $O$ Coruja já se encontrava no conto "Polítipo", escrito três anos antes de o romance aparecer no rodapé de $O$ Paiz. A descrição física de André é bem parecida com a que fez de Boaventura, protagonista do conto.

Imagine-se um homenzinho de cinco pés de altura sobre um de largo, com uma grande cabeça feia, quasi sem testa, olhos fundos, pequenos e descabellados; nariz de feitio duvidoso, bocca sem expressão, gestos vulgares, nenhum signal de barba, braços curtos, peito apertado e pernas arqueadas; e ter-se-á uma idéia do typo do meu malogrado amigo. ${ }^{95}$

Todavia, as semelhanças não são apenas de ordem física. As duas narrativas são protagonizadas por homens extremamente bons, que jamais são reconhecidos por essa virtude. André, com sua fealdade e jeito taciturno, provoca aversão inclusive naqueles a quem ajuda; Boaventura, ironicamente, tem a desventura de parecer-se com toda gente e, sempre que algo de ruim acontece, é tomado por culpado, mas nunca é reconhecido pelas boas ações que pratica. Isso porque era um tipo cuja fisionomia ninguém conseguia reter na memória, mas que todos supunham já ter visto em algum lugar:

Typo a que homem algum, nem mesmo aquelles a quem o

\footnotetext{
${ }^{94}$ Cf. MÉRIAN, Jean-Yves. Aluísio Azevedo, vida e obra (1857-1913): O verdadeiro Brasil do século XIX. Rio de Janeiro: Espaço e Tempo, 1988, p. 488-489.

${ }^{95}$ AZEVEDO, Aluísio. Demônios. São Paulo: Teixeira \& Irmão editores, 1893, p. 226.
} 
infeliz, levado pelos impulsos generosos de sua alma, prestava com sacrifício os mais galantes obséquios, jamais encarou sem uma instinctiva e secreta ponta de desconfiança. ${ }^{96}$

Portanto, é provável que a ideia de criar uma personagem condenada ao fracasso pelas próprias virtudes já estivesse presente no imaginário do escritor, pelo menos três anos antes do início da redação do folhetim.

\subsection{Do folhetim ao livro}

$O$ Coruja foi publicado inicialmente como folhetim no jornal $O$ Paiz, por isso consideramos relevante analisar alguns dados obtidos do microfilme do jornal durante esse ano: tiragem, periodicidade, perfil do jornal, distribuição das seções e localização do romance dentro do periódico. ${ }^{97}$

Fundado em 1884 por João José dos Reis Júnior (Juca Reis), com redação à Rua do Ouvidor, O Paiz tinha forte tendência republicana. De 1885 até 1889, o periódico foi dirigido por Quintino Bocaiúva. Era um dos jornais mais vendidos à época, ao lado do Correio da Tarde, O Jornal do Comércio e a Gazeta do Rio. ${ }^{98}$

Esse periódico era, em geral, composto por quatro páginas. Abrindo a publicação, havia a seção "O Paiz", espécie de editorial não assinado com temas da atualidade à época, trazia informações que iam de artigos em prol da República a notícias sobre inauguração de linhas ferroviárias e até explicações sobre o caso Malta. ${ }^{99}$ Crime polêmico, envolvendo a morte misteriosa de um homem pela polícia e que foi tema recorrente durante meses, ora ocupando essa seção, ora a "Seção livre", com vários artigos assinados por um médico-legista, inclusive com detalhes sobre as exumações.

\footnotetext{
${ }^{96}$ AZEVEDO, Aluísio. Demônios. São Paulo: Teixeira \& Irmão editores, 1893, p. 227.

${ }^{97}$ Incluímos a reprodução de algumas páginas do jornal nos anexos.

98 Cf. SODRÉ, Nelson Werneck. História da imprensa no Brasil. São Paulo: Martins Fontes, 1983, p. 266.

${ }^{99}$ Essa questão deu origem a um dos folhetins de Aluísio Azevedo, Mattos, Malta ou Matta? Dados sobre a edição dessa obra foram apresentados na nota 40 do capítulo 1.
} 
A seção "Telegramas: serviço especial do Paiz" era composta por notícias de outras regiões do Brasil e notas internacionais. $\mathrm{Na}$ intitulada "Tópicos do dia" havia informações variadas, tanto políticas como comerciais. Na sequência, vinha o tópico "Noticiário", bem eclético, com notas políticas, criminais e sobre lançamento de livros. Na página 2 eram compostas as seções "Avisos" - com informações corriqueiras, que iam desde onde comprar um vestido de noiva, até a data de pagamentos de funcionários do Ministério; a coluna "Estrangeira", que geralmente noticiava fatos de Portugal, Inglaterra e França; a "Seção interior", com informações recebidas da província; e a intitulada "Literatura", geralmente assinada, em que se anunciavam lançamentos literários. No rodapé dessa página era apresentado o folhetim.

Na página 3 havia uma seção curta, sob o título "Ecos de toda parte", com tiradas irônicas e piadas. No item "Memorial", espécie de classificado, o leitor encontrava endereços de profissionais liberais, hotéis e informações afins. Logo em seguida, vinha a "Seção livre", composta de reclames de utilidade pública. Na quarta página tinham lugar os anúncios publicitários e a "Seção comercial", com tabelas de preços, gráficos sobre a oscilação do câmbio, cotações de apólices e outras informações do gênero.

As quatro páginas do jornal seguiam mais ou menos o padrão apresentado. Eventualmente, esse número era ampliado para seis ou oito, sendo as páginas extras usadas para propagandas publicitárias. Mas não se pôde observar uma regularidade dessa oscilação no período analisado. Talvez essa configuração dependesse do número de anunciantes em determinado período.

Durante o ano analisado, dois folhetins foram publicados concomitantemente no início do primeiro semestre: Mulher funesta, de Georges Maldague, ${ }^{100}$ e Amores de província, de Xavier Montépin. ${ }^{101}$

\footnotetext{
${ }^{100}$ Segundo Marlyse Meyer, trata-se do pseudônimo de Josephine Maldague: "São muito frequentes as autoras de folhetins escondidas por pseudônimos masculinos; sempre interessada pela condição feminina, Maldague foi autora de vários folhetins de sucesso, publicados, como era de praxe, na imprensa parisiense e retomados por jornais de província”. MEYER, Marlyse. Folhetim. São Paulo: Companhia das Letras, 2005, p. 228.

${ }^{101}$ Henry Xavier Amon Perrin, conde de Montépin (1823-1902). Escritor francês, autor de romances, novelas e dramas populares, destacou-se como escritor de folhetins. Segundo Gramsci, seus romances são de pura intriga, mas possui um conteúdo ideológico conservador reacionário. In: MEYER, Marlyse. Folhetim, São Paulo: Companhia das Letras, 2005, p. 212. A influência do escritor francês repercutiu inclusive na telenovela brasileira: em 1966, a TV Excelsior exibiu Almas de pedra, com roteiro de Ivani
} 
A partir de meados de fevereiro, apenas Mulher funesta passa a ocupar todo o rodapé do jornal. ${ }^{102}$

As tiragens durante o ano de 1885 variaram bastante. ${ }^{103} \mathrm{O}$ ano começa com 14 mil exemplares no dia $1^{\circ}$ de janeiro e sobe para 15 mil em 28 do mesmo mês. A polêmica do caso Malta pode ter sido responsável por esse aumento na tiragem. Em maio, o número chega a 16 mil, mantendo-se até 29 de setembro, quando passa para 17 mil. Sobe novamente em $1^{\circ}$ de outubro para 18 mil exemplares. E tem mais duas alterações da ordem de um milhar, nos dias 10 e 27 de dezembro. Portanto, ao final do ano foram impressos 20 mil exemplares do jornal.

O Coruja foi publicado do dia 2 de junho a 12 de outubro. De acordo com o exposto acima, observa-se que houve aumento de dois mil exemplares durante esse período, mas não podemos afirmar que a publicação do romance tenha contribuído para esse aumento de vendagem.

A despeito de a grande popularidade do romance-folhetim ter começado na Inglaterra, foi na França, no final da década de 1830, sobretudo com obras de Alexandre Dumas, Honoré de Balzac e Eugène Sue, que o gênero ganhou notoriedade. No Brasil, segundo Laurence Hallewell, as primeiras traduções de folhetins franceses datam de 1939, quando José Rocha traduziu Os mistérios de Paris, de Eugène Sue, e $O$ conde de Monte Cristo, de Alexandre Dumas, para o jornal O Commercio. É o mesmo estudioso quem nos informa o motivo de tantos escritores brasileiros terem se dedicado a esse tipo de publicação: ${ }^{104}$

Por volta de 1870, mesmo um escritor desconhecido poderia receber mais ou menos $70 \$ 000$ por mês pela tradução de folhetins do francês, um nome consagrado que produzisse originais brasileiros

\footnotetext{
Ribeiro, baseada em seu romance Mulheres de bronze.

${ }^{102}$ Alguns anúncios foram publicados no jornal para divulgar o romance-folhetim de Aluísio Azevedo. No noticiário do dia 2 de junho de 1885, lê-se: "Encetamos hoje a publicação, em folhetim, do romance do Sr. Aluizio Azevedo, que há dias anunciamos. A nova produção do estimado escritor, acreditamos, terá a justa aceitação com que o público fluminense acolheu as outras.” Jornal $O$ Paiz, 2 jun. 1885, p. 1.

${ }^{103}$ Esses dados sobre as tiragens foram retirados do cabeçalho do próprio jornal $O$ Paiz durante o ano de 1885, embora não possamos afirmar sua veracidade, achamos por bem apresentá-los.

${ }^{104} \mathrm{O}$ primeiro romance brasileiro de destaque a aparecer nos rodapés dos jornais brasileiros foi Memórias de um sargento de milícias, de Manuel Antônio de Almeida, publicado no Correio Mercantil, de 27 de junho de 1852 a 31 de julho de 1853. Cf. HALLEWELL, Laurence. O livro no Brasil (Sua história). São Paulo: T.A. Queiroz/ Edusp, 1985, p. 147.
} 
poderia ganhar $200 \$ 000$ por mês - ou seis vezes o salário de um professor de escola rural - o suficiente para que Aluísio Azevedo vivesse, nessa ocasião, exclusivamente de seus escritos. ${ }^{105}$

Marlyse Meyer reitera que o mesmo fenômeno de sucesso do romance-folhetim alcançado pelo jornal $O$ Commercio se estende para todos os jornais da corte: "Ainda que não existam as necessárias pesquisas, de difícil execução dada a escassez de dados sobre tiragens e publicações, não faltam indícios da correlação entre a prosperidade do jornal e o folhetim". ${ }^{106}$ Como vimos anteriormente, o aumento de 2 mil exemplares durante a publicação do romance $O$ Coruja pode confirmar essa afirmação da estudiosa, uma vez que Aluísio Azevedo já era um escritor relativamente conhecido naquela época.

Em seu estudo sobre a história da imprensa no Brasil, Nelson Werneck Sodré afirma que, via de regra, o folhetim era o melhor atrativo do jornal, por isso a seção mais procurada: "Ler folhetim chegou a ser um hábito familiar, nos serões das províncias e mesmo na Corte, reunidos todos os da casa, permitida a presença das mulheres. A leitura em voz alta atingia os analfabetos, que eram a maioria". ${ }^{107}$

O estudioso também aponta que - apesar de inúmeros escritores da época, como Machado de Assis, Joaquim Manuel de Macedo e Raul Pompéia, entre outros, terem tido seus romances publicados inicialmente como folhetim - apenas Aluísio Azevedo se aproximou do modelo europeu e que seus livros escritos com essa intenção são justamente inferiores por seguir tal paradigma. ${ }^{108}$

Marlyse Meyer não é da mesma opinião. Para ela, o único escritor brasileiro que tentou seguir à risca tal modelo foi Carneiro Vilela, com o seu A emparedada da rua Nova. Aponta também para a influência da temática francesa em alguns escritores brasileiros, caso da semelhança entre as personagens Cora, de Mulheres de bronze, de Montépin, e Lucíola, do romance homônimo de José Alencar.

\footnotetext{
${ }^{105}$ HALLEWELL, Laurence. O livro no Brasil (Sua história). São Paulo: T.A. Queiroz/ Edusp, 1985, p. 140.

${ }^{106}$ MEYER, Marlyse. Folhetim. São Paulo: Companhia das Letras, 2005, p. 294.

${ }^{107}$ SODRÉ, Nelson Werneck. História da imprensa no Brasil. São Paulo: Martins Fontes, 1983, p. 243.

108 Sobre esse "modelo europeu", Werneck explica: "Esses autores, franceses na maioria, sabiam dar ao folhetim o interesse que representava o segredo de seu sucesso entre o público, com enredo complicado, a trama difícil, a ausência de compromisso com o verdadeiro e até com o verossímil”. Idem, p. 244.
} 
Sobre os folhetins de Aluísio Azevedo, a pesquisadora afirma que Girândolas dos amores não tem os necessários atrativos folhetinescos. Segundo ela, as intromissões constantes do narrador tornam o livro interessante para a crítica, mas seria de difícil ingestão pelo público aficionado em folhetim. Destaca também as obras $A$ condessa Vésper e A mortalha de Alzira e são tecidos elogios à construção divertida e bem feita de Mattos, Malta ou Matta. ${ }^{109}$ O Coruja, no entanto, sequer é mencionado em seu estudo.

A prática de publicar os romances-folhetins em livro foi logo adotada pelos editores franceses, mas, no caso brasileiro, isso não se deu de maneira tão automática. Só a partir de 1860, com Baptiste Louis Garnier, esse procedimento passou a ser usado - mas, ainda assim, editor consciencioso, ele escolhia autores que tinham bom desempenho comercial, não apenas como escritor de folhetins. ${ }^{110}$

\subsection{Alguns dados sobre as edições}

A primeira edição do romance $O$ Coruja $^{111}$ em livro data de 1887 e foi publicada pela Mont'Alverne. Tratava-se de uma oficina de litografia, fundada por Augusto Carlos de Mont'Alverne, em 1886, e que funcionou de 1887 a 1900, no número 92 da rua Ouvidor, no Rio de Janeiro. ${ }^{112}$

A segunda edição da obra só viria a lume em 1894, pela Magalhães \& Cia., de Domingos Magalhães, também responsável pela primeira edição de Livro de uma sogra, no ano seguinte.

\footnotetext{
${ }^{109}$ Cf. MEYER, Marlyse. Folhetim, São Paulo: Companhia das Letras, 2005, p. 306-8.

110 "O ano de 1888 foi um marco para a consagração literária de Aluísio Azevedo. Foi na verdade neste ano que assinou os primeiros contratos com a Garnier para a reedição de $O$ homem, $O$ mulato, Casa de pensão e $O$ Coruja. Tudo isso foi possível graças ao sucesso sem precedentes de $O$ homem, alguns meses antes: três edições de 1.900 exemplares foram vendidas entre outubro e dezembro de 1887." Cf. MÉRIAN, Jean-Yves. Aluísio Azevedo, vida e obra (1857-1913): O verdadeiro Brasil do século XIX. Rio de Janeiro: Espaço e Tempo, 1988, p. 434.

${ }^{111}$ Para o levantamento das edições da obra em questão, pesquisamos nos acervos da Fundação Biblioteca Nacional, no acervo das bibliotecas municipais de São Paulo e das seguintes universidades: USP, Unicamp, UFMG, UFRJ. Além da aquisição de algumas edições em sebos.

${ }^{112}$ Cf. FERREIRA, da Costa Orlando. Imagem e Letra: Introdução à bibliologia brasileira: a imagem gravada. São Paulo: Edusp, 1994, p. 412.
} 
Infelizmente, não conseguimos localizar nenhum exemplar dessas duas primeiras edições nas bibliotecas por nós consultadas.

Em 1895, o romance $O$ Coruja é editado pela B. L. Garnier ${ }^{113}$ e, dois anos depois, Hippolyte Garnier compra os direitos autorais sobre as obras completas de Aluísio Azevedo, composta por onze livros já publicados anteriormente, alguns inclusive pelo próprio Garnier. Três outras reedições do livro foram feitas por essa editora $(1889,1898$ e 1919). Pela mesma casa publicaram-se também seis edições de $O$ mulato e quatro de Casa de pensão. $O$ cortiço teve 27 edições, até a obra do escritor maranhense ter sido considerada legalmente como de domínio público. ${ }^{114}$

O romance $O$ Coruja só será reeditado novamente em 1940, pela Briguiet \& Cia., quando a loja Garnier e os direitos sobre as obras de vários escritores brasileiros foram vendidos para Ferdinand Briguiet e Companhia, em 1934. Posteriormente, com a morte de Ferdinand, seu sobrinho daria ao empreendimento o nome Livraria Briguiet-Garnier. Por essa casa, a obra completa de Aluísio Azevedo teve apenas uma edição, realizada entre 1937 e $1941 .^{115}$

Nas obras completas de Aluísio Azevedo pela Livraria Martins Editora, O Coruja é lançado em 1954, com prefácio de Nogueira da Silva. Nas edições subsequentes, o texto introdutório passa a ser assinado por Raimundo de Menezes. Pelo levantamento bibliográfico feito por nós, nessa casa editorial o livro obteve mais cinco reedições (1959, 1961, 1963, 1968, 1973), a última realizada em convênio com o Instituto Nacional do Livro.

Mais recentemente, em 2005, o romance integrou o segundo volume das obras completas do escritor, publicadas pela editora Aguilar. Três anos depois, foi lançado pela editora Global, tendo como base o texto da Livraria Martins. Inclusive a introdução de Raimundo Menezes foi mantida.

\footnotetext{
113 Adquirimos um exemplar desta edição. A obra faz parte da série intitulada "Coleção literatura brasileira". No frontispício consta a informação $5^{\mathrm{a}}$ ed., portanto, devem ter sido desconsideradas as publicações de 1887 e 1894. Nessa edição não há introdução nem posfácio.

${ }^{114}$ Cf. HALLEWELL, Laurence. O livro no Brasil (Sua história). São Paulo: T.A. Queiroz/Edusp, 1885. p. 183 , p. 192.

${ }^{115}$ Idem, p. 194 e 356.
} 


\subsection{A recepção crítica}

Achamos relevante para este trabalho apresentar breve explanação sobre a recepção da obra de Aluísio Azevedo, com destaque para O Coruja. Isso porque, durante esse percurso, levantaremos algumas questões que serão retomadas e desenvolvidas nos próximos capítulos.

De maneira geral, os estudiosos costumam dividir a obra de Aluísio Azevedo em dois segmentos. De um lado, estariam as de indiscutível qualidade literária, caso d'O mulato, O cortiço, O homem e Casa de pensão; de outro, os livros produzidos ao "correr da pena", destinados às folhas matutinas e, portanto, escritos para atender à demanda dos leitores de jornais. Essa divisão contribuiu para que grande parte dos romances, relegada a esse segundo agrupamento, despertasse pouco interesse de estudo por parte da crítica. No caso da obra que escolhemos para análise, alguns estudiosos a condenam; outros consideram suas qualidades, mas ainda assim lamentam o fato de ela ter sido escrita apressadamente para ser publicada em folhetim.

Para Antonio Arnoni Prado, o grande problema da avaliação literária da prosa aluisiana "foi a contaminação acadêmica da crítica, muito própria no âmbito das sociedades periféricas, que insistia em medir a qualidade de seus romances com base no ideário artístico do naturalismo de Émile Zola". ${ }^{116}$ Como veremos a seguir, a fortuna crítica que conseguimos consultar durante nossos estudos nos permite concordar, mas apenas em parte, com o que foi apresentado por esse pesquisador.

Entre os primeiros que saudaram a estreia de Aluísio Azevedo como romancista está Araripe Júnior. ${ }^{117}$ Durante o ano de 1888, ele publicou uma sequência de 25 artigos na revista Novidades, ${ }^{118}$ em que analisa a influência de Zola na produção do

\footnotetext{
${ }^{116}$ PRADO, Antonio Arnoni. "Aluísio Azevedo e a crítica". Aluísio Azevedo - Ficção completa em dois volumes. Rio de Janeiro: Editora Nova Aguilar, 2005, p. 43.

${ }^{117}$ No final da década de 1950, os textos desse importante crítico brasileiro, que estavam dispersos em várias fontes, foram reunidos e editados em cinco volumes, como resultado da pesquisa de estudiosos da Casa Rui Barbosa, sob a direção de Afrânio Coutinho. Os artigos que nos interessam estão em Obra crítica de Araripe Júnior, v. II (1888-1894). Rio de Janeiro: Ministério da Educação e Cultura e Casa Rui Barbosa, 1960. Muito embora, já em 1881, o crítico tivesse escrito sobre $O$ mulato e, em 1884, saudado o lançamento de Casa de pensão.

118 JÚNIOR, Araripe. “A Terra, de Emílio Zola, e o Homem, de Aluísio Azevedo". In: Obra crítica de
} 
escritor maranhense.

A série de textos tem início com uma espécie de panorama histórico, em que o crítico trata da evolução do romance desde a epopeia clássica até a produção do século XIX. Isso porque, para Araripe Júnior, “[...] o romance, ou o episódio pitoresco da vida, tem por base a ficção, tendência existente no homem desde a época em que suas faculdades atingiram certo desenvolvimento psíquico". ${ }^{119}$ Portanto, para ele, a fórmula encontrada pelos romancistas do século XIX não apareceu arbitrariamente, foi se condensando ao seguir um percurso de tradição nos diferentes países, e foi na Inglaterra, com escritores como Jonathan Swift, Daniel Defoe e, principalmente, Walter Scott, que o romance teria atingido sua forma exemplar.

Vários artigos são dedicados à tradição francesa até chegar em Émile Zola. Para Araripe, o grande mérito desse escritor estaria na maneira como conseguiu proceder "à desintegração das formas do romance fisiológico, para depois integrá-lo sob o ponto de vista sociológico". ${ }^{120}$ O crítico elogia sua grande capacidade de manter a unidade artística de uma obra, o que certamente exigia muita energia e engenhosidade arquitetônica.

No entanto, para Araripe Júnior, Aluísio Azevedo estaria mais perto de exercer no Brasil um papel correspondente ao de Balzac na França, do que o feito por Zola, apesar de acreditar que, para isso, o escritor maranhense tivesse de estudar muito até conquistar um estado de ilustração que lhe permitisse ir além do que havia conseguido até então. Nesses artigos Araripe Júnior faz menção às obras do escritor desde o romance de estreia, $O$ mulato, passando por Casa de pensão, $O$ Coruja, $O$ homem até chegar em $O$ cortiço.

Dado que Aluísio pouco escreveu depois que assumiu a carreira diplomática, em 1895, não pôde por certo seguir as recomendações de Araripe Júnior para se tornar o "Balzac brasileiro", e tampouco sabemos se concordaria com tal sugestão. O estudioso também reitera que Aluísio jamais foi um mero copista dos moldes do Naturalismo francês, uma vez que criou uma fórmula nova, a única possível em um país jovem

\footnotetext{
Araripe Júnior, v. II. Rio de Janeiro: Casa de Rui Barbosa, 1958, p. 25 a 94.

${ }^{119}$ Idem, p. 28.

${ }^{120}$ Idem, p. 45.
} 
como o Brasil. Acentua que os métodos e processos experimentais de Zola foram possíveis porque a sociedade francesa assim o permitia, pois:

[...] tiveram em vista uma sociedade decadente, de natural tristonha, que decresce, mingua, exausta, senão condenada a perecer. No Brasil, o espetáculo seria muito outro, - o de uma sociedade que nasce, que cresce, que se aparelha, como a criança, para a luta. Ora, nada mais natural do que uma inversão nos instrumentos. Um cadáver não se observa do mesmo modo que um ser que ofega de vigor. $^{121}$

A opinião de Araripe Júnior sobre $O$ Coruja difere muito da que tem sobre Casa de pensão e $O$ cortiço. Enquanto nestes dois livros o espírito do romancista abrange e trata com facilidade a ligação das personagens entre si e com os aspectos exteriores, em O Coruja seu problema foi justamente querer criar um romance de tese. Ou seja, para Araripe Júnior, quando Aluísio Azevedo tenta escrever uma obra diferente do que ele chama de "essencialmente representativo" e envereda para o caminho das memórias e das confissões, "pode conseguir resultados até certo ponto; mas não tardará em saltar fora do molde, perturbando assim a harmonia da obra de arte". ${ }^{122}$

Não obstante a importância da crítica de Araripe à obra aluisiana — que, como vimos, foi precedida de vasta e rigorosa explanação sobre o romance, o que bem demonstra sua grande erudição —, seu julgamento estava permeado por ideias pautadas em sua filiação naturalista. Chegou a acreditar, por exemplo, que os problemas dos romancistas brasileiros, inclusive seus deslizes gramaticais, advinham das adversidades climáticas: "O tropical não pode ser correto. A correção é o fruto da paciência e dos países frios; nos países quentes a atenção é intermitente". ${ }^{123}$

O crítico José Veríssimo também aponta as influências francesas na obra de Aluísio Azevedo. Mas antes de tratar da obra desse escritor, faz um preâmbulo sobre o naturalismo francês. Segundo ele, o grande demérito desse movimento literário foi a vulgarização da arte:

\footnotetext{
${ }^{121}$ JÚNIOR, Araripe. “A Terra, de Emílio Zola, e o Homem, de Aluísio Azevedo”. In: Obra crítica de Araripe Júnior. v. II, Rio de Janeiro: Casa de Rui Barbosa, 1958, p. 71.

${ }^{122}$ Idem, p. 88.

${ }^{123}$ Idem, p. 70.
} 
Os seus assuntos prediletos, o seu objeto, os seus temas, os seus processos, a sua estética, tudo nele estava ao alcance de toda a gente, que se deliciava com se dar ares de entender literatura discutindo livros que traziam todas as vulgaridades da vida ordinária e se lhe compraziam na descrição minuciosa. Foi também o que fez efêmero o naturalismo, já moribundo em França quando aqui nascia. ${ }^{124}$

Ao discorrer sobre as obras dos três representantes do Naturalismo no Brasil Aluísio de Azevedo, Júlio Ribeiro e Raul Pompéia -, o crítico explicita a sua predileção pela obra $O$ Ateneu, para ele, a mais original produzida no período, justamente por não ter seu autor se pautado tanto pelo modelo francês, muito embora o livro não fosse tão bem composto como as melhores obras de Aluísio de Azevedo: $O$ cortiço, O homem e Casa de pensão. No capítulo dedicado ao Naturalismo e ao Parnasianismo, no seu livro História da literatura brasileira, apenas esses três livros do escritor maranhense são mencionados, além de breve alusão à obra $O$ mulato. Para Veríssimo, "O resto de sua obra, de pura inspiração industrial, é de valor somenos". ${ }^{125}$

Portanto, dos dois críticos contemporâneos a Aluísio Azevedo aqui retomados, apenas Araripe Júnior debruçou-se um pouco mais sobre a obra do escritor maranhense e, ainda assim, pouco escreveu sobre $O$ Coruja.

E o que teriam dito os críticos posteriores sobre esse romance?

Seria impossível darmos conta da totalidade da fortuna crítica dedicada à obra de Aluísio Azevedo nessa pesquisa. Portanto, percorreremos apenas mais alguns estudos, destacando a recepção da obra $O$ Coruja.

Em discurso proferido na sessão solene extraordinária do dia 21 de julho de 1914 para ocupação da cadeira 4, que pertencera a Aluísio Azevedo, Alcides Maya disserta sobre o esforço desse escritor em implementar o Naturalismo no Brasil. Para ele, essa escola literária não teve êxito pois, ao querer "arrancar do artista a sua faculdade característica, esqueceu que a arte é realidade idealizada, não a cópia da realidade; e falhou por isso, por haver tentado substituir o símbolo pelo modelo, a intuição pela

\footnotetext{
${ }^{124}$ VERÍSSIMO, José. História da literatura brasileira: de Bento Teixeira (1601) a Machado de Assis (1908). Rio de Janeiro: Topbooks, 1998, p. 340.

${ }^{125}$ Idem, p. 341.
} 
experiência, a síntese pela análise". ${ }^{126}$

Alcides Maya apresenta o esboço da produção do escritor maranhense, em que aponta $O$ cortiço como "o mais perfeito de seus romances", para, logo em seguida, dedicar longo parágrafo à obra $O$ Coruja. Transcrevemos a seguir esse trecho na íntegra, pois, além de sua importância, é retomado em estudos posteriores.

Entretanto, a grande criação de Aluísio Azevedo é outra, é uma figura sombria crispada comicamente a sofrimentos de tragédia interior, é um ser humilde, feio e miserável, quase Alceste, meio Quasímodo, triste como a dor, grande como um protesto atirado ao destino, é o Coruja. Esta criatura de arte, que roça pelo símbolo, não tem rival no romance brasileiro. À verdade pessoal junta a poesia amarga de um combate sem tréguas com a sorte injusta. Ergue-se na existência como a imagem do dever e é o dever que o esmaga; a sua única ventura é a bondade e chega a duvidar dela, a odiá-la; o amor é o seu sonho de todas as horas e só inspira aversão; possui todas as virtudes e são as próprias virtudes que o atraiçoam, que o condenam à derrota, que o matam. Ah! que pena sentimos pensando no que poderia ter sido $O$ Coruja, se Aluísio Azevedo houvesse compreendido o valor excepcional, na sua obra, dessa criação! É o seu volume mais descuidado, talvez o único de que desdenhara. Dános a impressão de ter sido composto às pressas, sobre o joelho. Registram-se casos assim na vida literária: quem soube penetrar em tantas consciências, não se entendeu a si mesmo... ${ }^{127}$

Se, por um lado, Alcides Maya aponta as qualidades do romance, sobretudo a construção da personagem André, por outro, lamenta o fato de o escritor tê-lo redigido às pressas. De certa forma, há nesse posicionamento a sentença decretada posteriormente por grande parte da crítica, que passa a dividir a sua obra em dois grupos: os livros preparados com calma para edição definitiva e os produzidos rapidamente para figurar nos folhetins.

\footnotetext{
${ }^{126}$ MAYA, Alcides. Discurso proferido na sessão solene extraordinária do dia 21 de julho de 1914 na Academia Brasileira de Letras. Disponível em: <www.academia.org.br/abl/media/Tomo\%20I\%20\%201897\%20a\%201919.pdf. p. 669>. Acesso em: maio de 2011.

${ }^{127}$ Ibidem.
} 
Essa divisão é também defendida pela pesquisadora, Lúcia Miguel-Pereira, para quem o Naturalismo entre nós foi ainda mais postiço do que o Romantismo. Sua posição é a de que só quando o Realismo exagerou-se no Naturalismo, dando a Zola êxito retumbante na França e a Eça de Queirós em Portugal, é que se instalou definitivamente no Brasil com Aluísio Azevedo. ${ }^{128}$ Ao analisar a obra dos escritores naturalistas, a estudiosa destaca as limitações impostas pelas regras da nova escola: "o fatalismo que, privando total e exageradamente de arbítrios as personagens, lhes mecaniza os conflitos; a escravização ao concreto, cerceando o poder criador; o moralismo, o pedantismo, a prolixidade, a declamação". ${ }^{129}$

Ao se deter na obra de Aluísio Azevedo especificamente, Lúcia Miguel-Pereira afirma que ele não realizou inteiramente sua vocação como escritor, pois "Houve como que uma impotência nesse romancista profuso - a impotência dos criadores que não superam a realidade tangível, porque a observação neles não se prolonga pelo senso estético". ${ }^{130}$ Apesar de mais frequentemente apontar os problemas de construção da obra aluisiana como um todo, a estudiosa afirma que a grande contribuição de Aluísio Azevedo foi a sua capacidade de fixar as coletividades, como observa nas obras Casa de pensão e $O$ cortiço:

Essa visão panorâmica parece constituir a grande qualidade de Aluísio Azevedo como romancista, esse poder de fixar as coletividades representa sua maior contribuição para o nosso romance. Só nos momentos em que vê o indivíduo em função do meio a que pertence, como parte dele, e não como um caso a estudar isoladamente, é que escritor se sente em seu ambiente. ${ }^{131}$

Lúcia Miguel-Pereira faz apenas duas alusões à obra $O$ Coruja. A primeira para dizer que, a despeito de ter sido escrita caprichosamente, como foi também o caso de $O$ homem, Filomena Borges e O livro de uma sogra, trata-se de uma obra ilegível. A segunda vez que se refere ao romance é para compará-lo à construção bem-sucedida de $O$ cortiço e outras criações do escritor. Em seguida, afirma que em Casa de pensão e $O$

\footnotetext{
${ }^{128}$ MIGUEL-PEREIRA. Lúcia. História da literatura brasileira. v. XII. Rio de Janeiro: José Olympio, 1957, p. 137.

${ }^{129}$ Idem, p. 156.

${ }^{130}$ Idem, p. 137.

${ }^{131}$ Idem, p. 152.
} 
Coruja o escritor determina de antemão o futuro das personagens, e isso fragiliza a construção. A mesma questão é apontada por Eugênio Gomes, como veremos adiante.

Em certa altura de sua análise, Lúcia Miguel-Pereira afirma que, ao seguirem os passos de Zola e Eça de Queirós, os naturalistas brasileiros não atentaram para as diferenças entre as sociedades francesa e portuguesa e o nosso meio, que ainda estava em formação: “[...] sem perceberem que o que lá refletia a desagregação da burguesia, aqui não passava de anedota isolada". ${ }^{132}$ Parece-nos que Aluísio Azevedo não pode ser enquadrado nessa generalização, pelo menos no que diz respeito à obra $O$ Coruja, como tentaremos mostrar mais adiante.

Josué Montello, em capítulo que assina na obra A literatura no Brasil: Era realista, era de transição, também faz interessante estudo sobre o Naturalismo brasileiro. Como os críticos anteriores, apresenta o período na perspectiva da influência estrangeira, pois acredita que: “[...] as transformações aqui não se realizam organicamente, de dentro para fora, como resultado da própria evolução da consciência nacional, mas como reflexo das ideias-forças de origem estrangeira". ${ }^{133}$ Todavia, diferentemente dos outros estudiosos até aqui apresentados, vê influência maior de Eça de Queirós sobre Aluísio Azevedo e outros escritores naturalistas em detrimento da influência francesa. Mas reitera que em nenhum dos representantes do Naturalismo brasileiro pode se encontrar "a ironia corrosiva com que Eça, na pintura da sociedade portuguesa, atendeu a seus propósitos de demolição". ${ }^{134}$

No que diz respeito à obra de Aluísio Azevedo, como os críticos anteriores, Josué Montello também separa a obra aluisiana entre bons romances e aqueles escritos para figurar em folhetins. Todavia, além de laurear Casa de pensão e $O$ cortiço, destaca também $O$ homem, O livro de uma sogra e $O$ Coruja, que considera como “obras sérias, à altura de seu renome e de sua vocação". 135 Sobre o romance escolhido por nós para análise, escreve:

\footnotetext{
${ }^{132}$ MIGUEL-PEREIRA. Lúcia. História da literatura brasileira. v. XII. Rio de Janeiro: José Olympio, 1957 , p. 130.

133 MONTELLO, Josué. "A ficção naturalista” In: COUTINHO, Afrânio e COUTINHO, Eduardo de Faria (Orgs.). A literatura no Brasil: Era Realista, era de transição. São Paulo: Global, 1997, p. 75.

${ }^{134}$ Idem, p. 74.

135 Idem, p.78-9.
} 
O Coruja parece ter sido elaborado sob o impulso da instantaneidade criadora que presidiu a redação dos romances de folhetim que Aluísio Azevedo disseminou na imprensa da Corte. Mas a verdade é que o livro, embora derivado dessa escrita de afogadilho, está longe de pertencer à categoria de trabalhos perecíveis em que se enquadram $A$ mortalha de Alzira e as Memórias de um condenado. ${ }^{136}$

Vale destacar também que neste mesmo volume de A literatura no Brasil: Era realista, era de transição, Afrânio Coutinho faz interessante distinção entre o Realismo e o Naturalismo, para concluir que, não fosse um ou outro livro de Aluísio Azevedo, Domingos Olímpio e Adolfo Caminha, poder-se-ia dizer que esse foi um movimento gorado no país, a despeito de suas influências poderem ser notadas em quase todos os escritores do período:

Pode-se mesmo afirmar que raros foram os escritores do final do século XIX e começo do XX que não se deixaram contaminar das ideias diretoras do Naturalismo. Mesmo a obra de Machado de Assis dele está impregnada, pois, cioso de sua independência e reagindo contra os seus exageros, não ficou imune à sua influência e soube tirar dele o que podia servir ao seu molho, para empregar a sua própria expressão. ${ }^{137}$

Dada a grande importância da crítica positivista e naturalista no Brasil para a chamada geração de 1870, Afrânio Coutinho assina o capítulo intitulado "A crítica naturalista positivista". Nele o crítico faz panorama sobre o ideário crítico que norteou as escolas de Recife e Fortaleza, seguido da súmula do pensamento de críticos como Sílvio Romero, Capistrano de Abreu, Araripe Júnior e José Veríssimo.

Apesar do elogioso comentário, Afrânio Coutinho não apresenta nenhuma análise da obra $O$ Coruja e apenas menciona Alcides Maya como o único grande crítico a chamar atenção para a qualidade do romance, transcrevendo exatamente parte do trecho citado por nós, quando mencionamos o discurso de posse do sucessor de Aluísio

\footnotetext{
${ }^{136}$ MONTELLO, Josué. "A ficção naturalista” In: COUTINHO, Afrânio e COUTINHO, Eduardo de Faria (Orgs.). A literatura no Brasil: Era Realista, era de transição. São Paulo: Global, 1997, p.79.

${ }^{137}$ COUTINHO, Afrânio. "A crítica naturalista e positivista". In: COUTINHO, Afrânio e COUTINHO, Eduardo de Faria (Orgs.). A literatura no Brasil: Era Realista, era de transição. São Paulo: Global, 1997, p. 19.
} 
Azevedo na Academia Brasileira de Letras.

Eugênio Gomes é dos poucos que, a nosso ver, apresenta uma abordagem diferente da linha geral seguida pelos críticos antecessores. Isso porque, além de não se estender em análises demoradas sobre a influência europeia na produção aluisiana, aponta as falhas da crítica ao dividir as obras do autor em dois segmentos: "É simples admitir que a pressa de fazer livros sobre livros o tivesse desencaminhado, obrigando-o a alinhavar as suas narrativas com o olho fixo no mercado. Mas o exame de suas ideias estéticas e de seus processos mostrará que as deficiências de sua obra têm outra explicação". 138

Essa explicação estaria no que o crítico chamou de "hibridismo de uma estética de transição". Eugênio Gomes desenvolve sua teoria a partir de depoimentos dados pelo próprio Aluísio sobre a dificuldade de escrever obras naturalistas no país. Segundo ele, diante do dilema de escrever para os leitores que estavam em pleno romantismo e para o pequeno grupo de críticos que acompanhavam a evolução do romance moderno, a opção do escritor foi conciliar as duas demandas. Portanto, quando mais tarde

[...] alguns críticos estranharam a dosagem de Romantismo que Aluísio Azevedo aplicara em suas criações, modeladas pela ciência experimental [...] não faziam mais do que escancarar a porta que o romancista deixara voluntariamente aberta. Isso significa que foi o próprio escritor maranhense que denunciou o hibridismo de sua estética de transição. ${ }^{139}$

Essas questões, tão bem apontadas por Eugênio Gomes, nos ajudam a confirmar nossa hipótese de que podemos ler $O$ Coruja como um romance em que o escritor utiliza o grotesco, categoria estética muito presente na literatura romântica, para construir uma obra de cunho naturalista. Mas, nesse caso, não apenas lançando mão da estética romântica para agradar aos leitores, mas, sobretudo, para construir um romance de formação às avessas, como será analisado nos próximos capítulos.

Eugênio Gomes foi também um dos poucos críticos a escrever alguns parágrafos sobre a obra $O$ Coruja. O estudioso retoma a visão de Alcides Maya, apesar de

${ }^{138}$ GOMES, Eugênio. Aspectos do romance brasileiro. Bahia: Progresso, 1958, p. 113.

${ }^{139}$ Idem, p. 118. 
considerá-la por demais elogiosa, pois acredita que o grande problema do romance está justamente no fato de Aluísio ter construído uma personagem excessivamente boa, no caso André, e, sobretudo, por ter postulado isso logo no início do romance. ${ }^{140}$

De fato, no final da primeira parte da obra, quando André vê d. Laura, mãe de Teobaldo, despedir-se do filho, com uma manifestação de afeto que ele jamais recebera, decide ser "bom”. Mas por que teria Aluísio, já na primeira parte do romance, apresentado de forma tão explícita essa característica da personagem que dá título à obra, escancarando assim o que poderia ter urdido de maneira sutil durante a construção do romance? Teria concebido as duas personagens centrais do romance para demonstrar tanto a impossibilidade da bondade absoluta de André, que se torna um homem amargo e infeliz, como a excessiva vaidade de Teobaldo, que o conduziu a um final trágico? Essas questões também serão desenvolvidas com mais fôlego nos próximos capítulos.

O romantismo apontado por Eugênio Gomes é também um dos pontos tratados por Sérgio Milliet na introdução ao romance $O$ cortiço, para a coleção "Obras completas de Aluísio Azevedo". Mas, diferentemente do crítico baiano, que viu os traços românticos como uma opção deliberada do escritor maranhense, Milliet acredita que em Aluísio esse temperamento romântico fundamental - "que o impele a escrever O Coruja, ao gosto hugoano da antítese do bem e do mal" ${ }^{\text {"141 }}$ — é que fez com que esse romance, apesar do valor literário, não bastasse para que seu autor pudesse ser considerado o maior representante do naturalismo brasileiro, título conquistado indubitavelmente com $O$ cortiço.

No prefácio para o romance $O$ Coruja, ${ }^{142}$ também para as obras completas publicadas pela Livraria Martins Fontes, Raimundo de Menezes pouco acrescenta ao visto até aqui. Ele retoma a crítica de Alcides Maya e lhe contrapõe as refutações de

\footnotetext{
140 "Pela simples técnica de apresentação inicial no romance, Coruja estava fadado a ser um paralítico, no plano da criação artística, não pelo defeito físico, que lhe valeu o apelido grotesco, mas porque o romancista o inutiliza desde o primeiro toque, quando se decide a projetá-lo como figura autônoma. [...] Aluísio Azevedo prejulga de maneira incisiva o personagem, em vez de levar o leitor insensivelmente a assistir o fracasso de idealismo absurdo através do desenvolvimento da ação." GOMES, Eugênio. Aspectos do romance brasileiro. Bahia: Progresso, 1958, p. 126.

${ }^{141}$ MILLIET, Sérgio. Introdução ao romance $O$ cortiço. In : AZEVEDO, Aluísio. $O$ cortiço. São Paulo: Livraria Martins Editora, 1959, p. 14.

${ }_{142}$ MENEZES, Raimundo de. Introdução ao romance $O$ Coruja. In : AZEVEDO, Aluísio. O Coruja. Livraria Martins Editora, 1963.
} 
Eugênio Gomes. As informações novas não são de cunho estético, mas vamos mencioná-las à guisa de curiosidade. O estudioso reproduz citação de Almeida Prado, na qual este afirma que Aluísio Azevedo passou pela vida um pouco como seu personagem Teobaldo. Hipótese da qual discordamos. A grande capacidade de trabalho do romancista, apontada por nós no primeiro capítulo deste estudo, está bem longe do diletantismo da personagem em questão. Cita também Augusto Fragoso, que viu em André uma caricatura de Capistrano de Abreu, tipo excêntrico pouco afeito a glórias e obsedado pela ideia de escrever um livro sobre a história do Brasil.

Nesse sentido, o prefácio de Nogueira da Silva, da edição de $1954,{ }^{143}$ é bem mais valioso. O estudioso vê pontos de contato entre os romances O Coruja e Casa de pensão. Além de levantar a hipótese de que a divisão do romance em três grandes partes, que podem ser lidas separadamente, desperta "a impressão vigorosa e funda de serem, de per si, romances à parte". ${ }^{144}$ Nogueira da Silva destaca ainda a maestria com que Aluísio conduz os diálogos durante a narrativa, de maneira natural, espontânea e lógica, afastando-os da retórica empolada. Aponta também a maneira impecável como o escritor traçou o perfil de André e as personagens que gravitam em torno dele, desde Teobaldo até Inezinha.

Josué Montello mantém a divisão da obra aluisiana em livros urdidos para realização artística e os escritos para folhetins, mas é dos poucos que inclui na lista de "bons romances" O livro de uma sogra e $O$ Coruja. Sobre este último, declara: "O Coruja - a que não se tem dado a devida importância na obra do romancista maranhense - é mais o livro de um discípulo de Balzac que de Zola, na técnica do realismo literário". ${ }^{145}$ Para esse estudioso, o livro "é um lance de comédia humana". ${ }^{146}$

Encontramos ainda dois estudos de Nelson Werneck Sodré sobre o Naturalismo. O primeiro encontra-se no capítulo intitulado "O episódio naturalista", da sua História da literatura brasileira. O mais interessante no capítulo é a introdução geral, em que

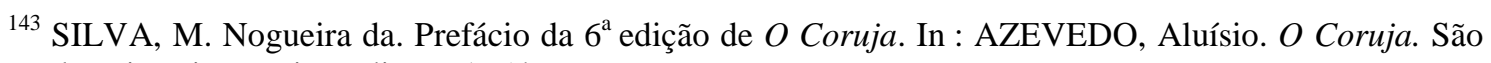
Paulo: Livraria Martins Editora, 1954.

${ }^{144}$ Idem, p. 12.

${ }^{145}$ MONTELLO, Josué. Aluísio Azevedo: trechos escolhidos. Rio de Janeiro: Agir, 1969, p. 12. (Coleção Nossos Clássicos, v. 68)

${ }^{146}$ SODRÉ, Nelson Werneck História da literatura brasileira. Rio de Janeiro: Civilização Brasileira, p. 12.
} 
compara as condições econômicas e europeias com a brasileira.

Para ele, Aluísio Azevedo foi um "ficcionista desigual, misto de grandezas e trivialidades" e que oscilava entre a crueza realista e a fantasia romântica. Apenas três livros são mencionados pelo estudioso: Casa de pensão ("em que há qualidades marcantes de ficcionista"), $O$ Coruja ("rascunho de grande romance") e $O$ cortiço ("romance plenamente realizado"). ${ }^{147}$ No mais, o historiador pouco diz por si mesmo sobre o movimento, pois apenas colige citações de Lúcia Miguel-Pereira, José Veríssimo e Olívio Montenegro. Werneck ressalta que entre nós o Naturalismo distanciou-se por demais da realidade e teve tendências regionalistas.

O outro livro de Nelson Werneck que nos interessa é Naturalismo no Brasil. O título nos fez supor denso estudo sobre o movimento entre nós. Todavia, dos cinco capítulos da obra, apenas um é dedicado ao caso brasileiro e grande parte sobre os grupos de intelectuais e escritores da Escola de Recife, da Academia Francesa e da Padaria Espiritual, movimentos cearenses. Nas poucas páginas dedicadas à análise literária, reproduz-se o modelo do estudo anterior, pois trata das obras Casa de pensão, $O$ cortiço e $O$ homem, mas apenas citando e coligindo textos de Lúcia Miguel-Pereira, Olívio Montenegro e Sílvio Romero.

Como vimos até aqui, Lúcia Miguel-Pereira é exaustivamente citada quando se fala do Naturalismo como um todo e da obra de Aluísio Azevedo, O cortiço, em particular. Sobre o romance $O$ Coruja, o texto de Alcides Maya é frequentemente mencionado, e apenas Eugênio Gomes e Nogueira da Silva avançam um pouco na leitura do romance. Quanto à influência francesa, diferentemente do que foi dito por Arnoni Prado, ainda que seja comum a associação com Zola, muitos críticos apontam na obra do escritor maranhense uma filiação com Balzac e Eça de Queirós.

Para finalizar, apresentaremos a seguir estudiosos que, a nosso ver, fugiram de certa repetição presente em grande parte da crítica, ao trazerem argumentos que permitem um outro olhar sobre a obra aluisiana. São eles: Antonio Candido, Franklin de Oliveira e Massaud Moisés.

${ }^{147}$ SODRÉ, Nelson Werneck História da literatura brasileira. Rio de Janeiro: Civilização Brasileira, p. 391. 
Na obra $O$ discurso e a cidade, ${ }^{148}$ Antonio Candido apresenta texto lapidar sobre a obra aluisiana no ensaio "De cortiço a cortiço". Não nos deteremos nele, pois não diz respeito especificamente ao romance por nós escolhido para estudo. Todavia, achamos por bem mencioná-lo, pois nesse ensaio o crítico apresenta não só uma análise da obra $O$ cortiço em uma perspectiva inédita - visto que compara essa obra com L'Assommoir, de Zola —, como também utiliza-se do que chama de "redução estrutural": "isto é, o processo por cujo intermédio a realidade do mundo e do ser se torna, na narrativa ficcional, componente de uma estrutura literária, permitindo que esta seja estudada em si mesma, como algo autônomo". ${ }^{149}$ Sobre esse ensaio, Arnoni Prado escreveu:

Antonio Candido na verdade é dos poucos, se não o único, a estudar as intenções naturalistas de Aluísio à luz da matriz europeia que o norteava, para transcrevê-la numa dimensão social que devassa a natureza econômica das relações de trabalho e contribui para fixar, num retrato tão autêntico quanto inovador, o significado profundo da coexistência social e humana entre exploradores e explorados na faina semiescravista do Brasil daquele tempo. ${ }^{150}$

Já Franklin de Oliveira, apesar do tom ufanista do artigo dedicado a Aluísio Azevedo,- pois inicia seu texto sobre o autor exultando a tendência renovadora do grupo maranhense do século XIX, com destaque para Gonçalves Dias, Rocha Lima, Celso Magalhães e Nina Rodrigues, só para citar alguns da longa lista arrolada pelo crítico -, não só aponta alguns problemas nos estudos feitos até então sobre a obra aluisiana, como faz alusão a aspectos sobre o romance $O$ Coruja que mereceram nossa atenção.

Segundo ele, diferentemente da geração de escritores franceses pós-1848, que "viram o homem menos como sujeito do que como objeto das circunstâncias sociais", ${ }^{151}$ Aluísio, ao implantar o Naturalismo no Brasil, conseguiu ultrapassar essa

148 CANDIDO, Antonio. O discurso e a cidade. São Paulo/ Rio de Janeiro: Duas Cidades/Ouro sobre Azul, 2004. O ensaio "De cortiço a cortiço" foi escrito em 1973.

${ }^{149}$ Idem, p. 9.

${ }^{150}$ PRADO, Antonio Arnoni. “Aluísio Azevedo e a crítica”. In: Aluísio Azevedo - Ficção completa em dois volumes. Rio de Janeiro: Nova Aguilar, 2005, p. 52.

${ }^{151}$ OLIVEIRA, Franklin. "Aluísio Azevedo." In: Literatura e civilização. Rio de Janeiro: Difel/MEC, 1978, p. 74. O artigo foi escrito em 1975. 
contradição. Daí o equívoco da crítica que, ao apontar para o excessivo romantismo em sua obra, não percebeu na verdade que o que havia ali era a busca da "autonomia do sujeito". Outro aspecto que ele rebate é a tendência geral de se elogiar a capacidade do escritor de movimentar cenas coletivas, mas não conseguir estudar o comportamento humano em sua individualidade:

Se com Aluísio o povo começa a ser o grande personagem do romance brasileiro, se a sua intenção crítica, quase pedagógica, refulge com vigor até em obras menores como A Condessa de Vésper (1902) [...], vemos que a sua pesquisa de tipos, fatos e situações, em diferentes camadas sociais, teria sido impossível se lhe faltasse capacidade de penetração psicológica — o seu poder de dar vida e corpo a agrupamentos humanos não elidia, antes, associava-se ao seu poder de desnudar a psicologia de cada agente das camadas sociais que representava. Esse poder é o poder de criar tipos. ${ }^{152}$

Para ilustrar a hipótese levantada acima, como modelo de criação individual na obra aluisiana, o crítico apresenta justamente André, protagonista do romance $O$ Coruja, e faz um paralelo entre essa obra e O Ateneu, de Raul Pompéia.

O código artístico de um não era o do outro. No entanto, os dois colégios são descritos de forma idêntica. Tanto Aluísio, quanto Pompéia, os descrevem como mundos fechados. Ambos os caracterizam como máquinas de fazer dinheiro, símbolo de uma sociedade alicerçada em privilégios. ${ }^{153}$

Antes da leitura desse ensaio do crítico maranhense, já tínhamos decidido pela análise do romance como uma espécie de romance de formação, caminho tomado por alguns críticos que estudam $O$ Ateneu. Defrontar com essa analogia entre os dois romances nos deu indícios de que nossa hipótese procedia. No entanto, há outro aspecto relevante levantado pelo estudioso que nos interessa. Ele considera que $O$ Coruja constitui ponto de transcendental importância na ficção brasileira, justamente porque Aluísio coloca como um dos temas centrais do romance "o problema da

\footnotetext{
${ }^{152}$ OLIVEIRA, Franklin. “Aluísio Azevedo.” In: Literatura e civilização. Rio de Janeiro: Difel/MEC, 1978 , p. 80

${ }^{153}$ Idem, p. 81.
} 
bondade que gera desastres".

Nesse sentido, André estaria na galeria de personagens universais contra os quais se voltam as suas próprias virtudes, caso do príncipe Mischkin, da obra O idiota (Dostoiévski) e Shen Te, de A alma boa de Setsuã (Brecht). Esses dois aspectos importantes, retirados do curto ensaio, serão retomados por nós nos capítulos posteriores, quando apresentaremos O Coruja como romance de formação. Nessa leitura, analisaremos em que medida a grandeza moral de André o condena ao fracasso.

Passemos agora ao que disse Massaud Moisés sobre o romance em análise. Depois das páginas preliminares, em que analisa o contexto histórico da produção literária no Brasil do último quartel do XIX, o crítico começa seu estudo de autores naturalistas e realistas por Aluísio Azevedo. Os primeiros romances citados são justamente os escritos como folhetim, que ele considera como "a faceta romântica" do escritor. Todavia, estranhamos o fato de $O$ Coruja não estar na lista de obras folhetinescas citadas pelo crítico, que menciona apenas a publicação do romance, em 1887, a despeito de apontar para as seguintes características do gênero, presentes na fatura da obra:

[...] O Coruja: publicada em 1887, não pertence ao grupo de obras escritas profissionalmente, e por isso tem merecido da crítica mais atenção. Ocorre, no entanto, que o prosador não teve como evitar a transposição de alguns vícios do folhetim para uma narrativa a que talvez desejasse emprestar a mesma gravidade com que elaborou $O$ Mulato e romances de igual têmpera. ${ }^{154}$

Contudo, independentemente de Moisés ter desconsiderado o fato de o romance ter sido urdido inicialmente como folhetim, é o único que aponta explicitamente para a possibilidade de a obra poder ser lida como um romance de formação: "O Coruja constitui uma 'educação sentimental', romance de aprendizagem, mas não da personagem que dá título à narrativa: o Coruja é figura secundária, ainda que relevante pelo papel desempenha. O 'Herói' é Teobaldo Henrique de Albuquerque". ${ }^{155}$ A despeito de não considerarmos que exista apenas uma personagem em formação neste

\footnotetext{
154 MOISÉS, Massaud. História da literatura brasileira: realismo e simbolismo. São Paulo: Cultrix, 2001, p. 32.

155 Ibidem.
} 
romance, aspecto que retomaremos nos próximos capítulos, essa observação do estudioso, de que o romance é uma espécie de 'educação sentimental', nos deu mais alento para a empreitada que tínhamos pela frente. Justamente porque o último parágrafo acerca do romance está longe de ser uma ovação:

Despido de intencionalidade científica ao pintar a burguesia decadente, sobretudo no flanco da política, $O$ Coruja flutua entre o esteticismo com vistas ao entretenimento e o flagrante verídico da conjuntura finissecular. Nem mesmo o esboço da história do internato - prenunciando $O$ Ateneu —, que ocupa as primeiras páginas, salva a obra do limbo, de onde apenas a retira o leitor desejoso de conhecer mais essa faceta do autor e acompanhar uma narrativa à Macedo, vazada num estilo viril, plástico e de inflexão teatral pela predominância do diálogo. ${ }^{156}$

Nos próximos capítulos apresentaremos nossa análise do romance $O$ Coruja, não com a pretensão de "retirá-lo do limbo", mas para desenvolvermos uma hipótese que temos a respeito da concepção dessa obra tão peculiar de Aluísio Azevedo.

${ }^{156}$ MOISÉS, Massaud. História da literatura brasileira: realismo e simbolismo. São Paulo: Cultrix, 2001, p. 33. 


\section{CAPÍtUlO 3 - A LEITURA D'o CORUJA COMO UM ROMANCE DE FORMAÇÃO}

Nossa pretensão é ler o romance $O$ Coruja a partir da concepção do Bildungsroman, e, nesse caso, teremos necessariamente de tratar da relação entre as personagens centrais: André e Teobaldo. Portanto, consideraremos que, se as duas personagens percorrem um caminho paralelo desde a infância até a maturidade, durante o qual a formação intelectual e sentimental de ambos é o foco, estamos diante de um romance de formação.

Todavia, no decorrer da análise, veremos que a obra não se encaixa nos paradigmas do protótipo consagrado pela crítica. Portanto, trata-se de um romance de formação, mas com características bastante peculiares.

Isso posto, tentaremos discutir, neste e nos próximos capítulos, o quanto $O$ Coruja enquadra-se na categoria do romance de formação, ainda que Aluísio Azevedo tenha utilizado figurações do grotesco para escrever um livro de formação às avessas.

Mas antes de tratarmos da obra propriamente dita, achamos por bem fazer um pequeno preâmbulo sobre o romance de formação.

\subsection{Alguns apontamentos sobre o romance de formação}

A palavra Bildungsroman teria sido empregada pela primeira vez em 1803, pelo professor de filologia clássica Karl Morgenstern, ${ }^{157}$ em uma conferência. Alguns anos depois, em 1820, o mesmo estudioso teria associado tal conceito ao romance de Goethe Os anos de aprendizado de Wilhelm Meister, nomeando assim um signo literário ainda

\footnotetext{
${ }^{157}$ A despeito do relevo adquirido por Morgenstern, Marcus Vinicius Mazzari alega tratar-se de um pioneirismo gratuito, "que poderia ter cabido já a Friedrich Blanckenburg, que em sua Tentativa sobre o romance valoriza sobretudo a representação do desenvolvimento ou da formação 'interior' do herói romanesco (em detrimento dos acontecimentos "exteriores "), descrevendo assim com mais propriedade do que Morgenstern o que seria um romance de formação". MAZZARI, Marcus Vinicius. Labirintos da aprendizagem. São Paulo: Editora 34, p. 99.
} 
presente na história da literatura e que se renova continuamente, mas quase sempre associado à obra supracitada.

No entanto, trinta anos depois, o próprio escritor alemão escreveria $O s$ anos de peregrinação de Wilhelm Meister, em que revê os conceitos postulados por ele no romance considerado protótipo do Bildungsroman, pois:

As três décadas que separam os dois romances são marcadas pelos desdobramentos políticos da Revolução Francesa e pela irrupção da Revolução Industrial. Goethe, antevendo as implicações da divisão capitalista do trabalho, é levado a uma reformulação de seu conceito de formação. Assim, enquanto Os Anos de Aprendizado proclamavam que o homem deve se desenvolver em todas as direções, o romance posterior faz outra colocação: a formação deve estar direcionada para uma profissão especializada, a inserção social é necessária desde o início. ${ }^{158}$

Os anos de aprendizagem é indubitavelmente um marco, obra basilar para a criação de um novo subgênero literário, mas Mikhail Bakhtin nos informa que a presença do romance de formação, ou homem em formação (em devir) no romance, ${ }^{159}$ é bem mais remota na história da literatura ocidental, ainda que a obra de Goethe apareça "como a primeira manifestação alemã significativa do 'romance social burguês' (Gesellschaftsroman)". ${ }^{160}$

$\mathrm{Na}$ antiguidade clássica, vamos encontrar exemplos desse tipo de narrativa em Ciropédia, de Xenofonte; na Idade Média, em Parcival, de Wolfram Von Eschenbach; no Renascimento, em Gargantua e Pantagruel, de Rabelais; no Neoclassicismo, em As aventuras de Telêmaco, de Fénelon. Bakhtin inclui em sua lista os livros de Goethe protagonizados por Wilhelm Meister e continua sua enumeração, citando David Copperfield (Charles Dickens), Henrique, o Verde (Gottfried Keller), Jean Christophe (Romain Rolland) e A montanha mágica (Thomas Mann) entre outros.

\footnotetext{
158 MAZZARI, Marcus Vinicius. Romance de formação em perspectiva histórica. São Paulo: Ateliê Editorial, p. 85.

${ }^{159} \mathrm{O}$ tema fundamental tratado por Bakthin é a espácio-temporalidade e a imagem do homem no romance, para tanto adota como critério o grau de assimilação entre o tempo histórico real e o homem nessa temporalidade.

${ }^{160}$ MAZZARI, Marcus Vinicius. Romance de formação em perspectiva histórica. São Paulo: Ateliê Editorial, p. 67.
} 
E a lista pode ser maior ou menor, de acordo com o corte estabelecido pelo estudioso do tema. Os mais rigorosos delimitam nessa categoria apenas os enredos concentrados no processo de educação da personagem, o que reduziria bastante a lista. Outros, exigem apenas a presença do desenvolvimento do protagonista, seja no âmbito educacional ou sentimental, o que permitiria a ampliação do corpus.

Diante dessas divergências, Bakhtin propõe a organização do gênero romanesco em geral em dois grandes grupos. De um lado, ficaria a maioria dos romances, ou seja, aqueles em que a imagem da personagem se mantém estática: "O herói é uma grandeza constante na fórmula do romance; as outras grandezas - o ambiente espacial, a situação social, a fortuna, em suma, todos os aspectos da vida e do destino do herói - são grandezas variáveis". ${ }^{161}$ Do outro lado, em número bem menor, estariam obras que produzem a imagem do homem em formação em narrativas nas quais:

A imagem do herói já não é uma unidade estática mas, pelo contrário, uma unidade dinâmica. Nesta fórmula de romance, o herói e seu caráter se tornam uma grandeza variável. As mudanças por que passa o herói adquirem importância para o enredo romanesco que será, por conseguinte, repensado e reestruturado. ${ }^{162}$

Bakthin continua sua categorização, classificando o romance de formação em subtipos. Haveria, assim, o romance cíclico, em que se mostra a trajetória do homem entre a infância e a mocidade ou entre a maturidade e a velhice. O livro As aventuras de Telêmaco, de Fénelon, pode ser incluído nessa categoria.

Ainda no tipo de formação cíclica, estariam romances caracterizados pela representação da vida e do mundo como experiência transformadora, que vai "do idealismo juvenil e da natureza sonhadora à sobriedade madura e ao praticismo". ${ }^{163}$ Como exemplo, podem ser citados Henrique, O Verde (Gottfried Keller) e Os anos de aprendizado de Wilhelm Meister (Goethe).

No terceiro modelo, seriam arrolados os romances de tipo biográfico e autobiográfico, pois é o destino do homem que determina seu caráter. David

\footnotetext{
${ }^{161}$ BAKTHTIN, Mikhail. Estética da criação verbal. São Paulo: WMF Martins Fontes, 2010. p. 205-224.

${ }^{162}$ Idem, p. 67.

${ }^{163}$ Idem, p. 220.
} 
Copperfield, de Dickens e Infância, adolescência e juventude, de Tolstói, são bons exemplos dessa categoria.

No quarto agrupamento ficariam os romances ditos didático-pedagógicos, em que o processo de educação delimita o curso da narrativa. Como exemplos puros podem ser citados Emílio, de Rousseau e Ciropédia, de Xenofonte. Mas haveria elementos desse protótipo em Goethe e Rabelais, por exemplo.

O estudioso russo reitera que mais de uma categoria pode ser encontrada na mesma obra e, nos últimos itens deste capítulo, veremos que no romance $O$ Coruja podem-se encontrar tanto elementos das duas primeiras categorias, pois o narrador nos permite acompanhar a trajetória de dois amigos da infância à maturidade, passando da representação do idealismo à vida prática, como elementos do tipo didáticopedagógico, uma vez que são apresentadas informações sobre o processo de educação das personagens centrais e secundárias do romance.

Todavia, tentaremos mostrar que todo o romance é urdido tendo como pano de fundo uma quinta categoria, considerada por Bakhtin como a mais importante, aquela na qual a evolução do homem não pode ser dissociada da evolução histórica. Nas palavras do estudioso, nesse caso,

A formação do homem efetua-se no tempo histórico real, necessário, com seu futuro, com seu caráter profundamente cronotópico. ${ }^{164}$ Nos quatro tipos anteriormente mencionados, a formação do homem se operava contra o pano de fundo imóvel de um mundo já concluído e, no essencial, totalmente estável. Mesmo quando ocorriam mudanças, estas eram secundárias e não atingiam os fundamentos do mundo. $\mathrm{O}$ homem se formava, se desenvolvia, mudava, no interior de uma época. ${ }^{165}[\ldots]$.

\footnotetext{
${ }^{164}$ Mikhail Bakhtin utiliza o termo cronótopo para referir-se ao tempo e ao espaço, isto é, à correlação das categorias espácio-temporais da maneira como foram assimiladas pela literatura.

${ }^{165}$ BAKTHTIN, Mikhail. Estética da criação verbal. São Paulo: WMF Martins Fontes, 2010, p. 221.
} 


\section{2. O romance de formação no "momento pós-goethiano"}

Em sua Teoria do romance, ${ }^{166}$ de 1916, Lukács argumenta que o modelo tradicional do romance de formação, postulado na obra Os anos de aprendizado de Wilhelm Meister, não seria mais possível no "momento pós-goethiano". Isso porque o idealismo presente nesse romance, em que a alma aspira à ação, tendo em vista uma atuação sobre a realidade, já não teria lugar no mundo, sobretudo porque mesmo no âmbito do romance de formação, que marcou o classicismo alemão, os ideários da comunidade não eram

[...] como nas antigas epopeias, o enraizamento espontâneo nas estruturas sociais e a solidariedade natural que daí resulta [...] Tratase muito mais de um ajustamento mútuo e de uma habituação recíproca entre indivíduos até então solitários e egoisticamente limitados a eles mesmos, do fruto de uma rica e enriquecedora resignação, coroamento de um processo educativo e maturidade conquistada e obtida com a própria autoridade. ${ }^{167}$

Todavia, ainda que distante do ideário épico, Lukács reconhece em Os anos de aprendizado de Wilhelm Meister uma ligação intrínseca entre as personagens em prol de um objetivo comum, ao passo que no "romance da desilusão" isso não seria mais possível, pois, diante da crise instalada entre o indivíduo solitário, protagonista do romance burguês, e o todo, representado pela coletividade épica, já não há qualquer possibilidade de ligação. $\mathrm{O}$ momento histórico do romance burguês determinaria que o indivíduo solitário e problemático fracassasse em seus empreendimentos. Por conseguinte, a narrativa desse percurso solitário refletiria no fracasso dos projetos exclusivamente individuais e o modelo de Goethe não faria mais sentido para os escritores posteriores, pois os protagonistas “exemplares", premissa exigida pelo romance de formação, não encontravam mais lugar no mundo.

Em outro texto, de 1936, Lukács volta a escrever sobre Os anos de aprendizado de Wilhelm Meister. Agora, de maneira mais detida sobre o romance propriamente dito,

\footnotetext{
${ }^{166}$ LUCKÁCS, Georg. Teoria do romance. Lisboa: Editorial Presença, [19--].

${ }^{167}$ Idem, p. 157.
} 
ressalta a importância do teatro no romance goethiano e postula que essa manifestação artística significaria "a libertação de uma poética da indigente e prosaica estreiteza do mundo burguês". 168

Todavia, se para Lukács a vivência teatral teria sido apenas um ponto de transição na formação de Wilhelm, a nosso ver, a passagem pelo teatro não foi somente uma etapa nesse processo, mas a fase mais importante dele. É por meio da sua inserção no mundo teatral que o protagonista desenvolve suas habilidades físicas nas aulas de esgrima e aguça sua concepção poética. Não apenas ao interpretar Hamlet, mas, sobretudo, ao cuidar para que a essência da estrutura da peça fosse mantida. O que se pode constatar nas ideias defendidas por ele nas discussões com Serlo a esse respeito, que são verdadeiras aulas de dramaturgia.

Durante a preparação para os ensaios e as apresentações, Wilhelm não apenas aprimora seu senso estético, como é estimulado a se relacionar com pessoas dotadas de personalidades bastante distintas. Vale dizer também que sua inserção em uma trupe teatral lhe permitirá conhecer Aurelie, atriz que cuida do pequeno Felix. Mais adiante no romance, saberemos tratar-se do próprio filho de Meister. E é justamente no dia em se descobre pai da criança, a quem já havia se apegado, que sente mais necessidade de instruir-se, pois, como pai, seria convocado a ensinar. ${ }^{169}$

As mudanças operadas tanto no plano físico como psicológico do protagonista são bem sintetizadas nas seguintes impressões do amigo de infância ao reencontrá-lo anos depois: "Werner garantiu que seu amigo estava mais forte e mais encorpado, mais distinto em sua natureza e mais agradável em seu comportamento". ${ }^{170}$ E se nos detemos na importância do teatro nessa obra de Goethe, é porque essa manifestação artística tem certa relevância no processo de formação de uma das personagens da obra $O$ Coruja, como veremos no próximo item deste capítulo.

Há mais um aspecto apontado por Lukács que nos interessa sobremaneira para aprofundar outro tópico do romance de formação: "Segundo a concepção de Goethe, a

\footnotetext{
${ }^{168}$ LUKÁCS, George. Posfácio. In: GOETHE, Johann Wolfgang Von. Os anos de aprendizado de Wilhelm Meister, de Johann Wolfgang von Goethe. São Paulo: Editora 34, 2009, p. 582.

${ }^{169}$ GOETHE, Johann Wolfgang von. Os anos de aprendizado de Wilhelm Meister. São Paulo: Editora 34, 2009 , p. 475.

${ }^{170}$ Idem, p. 446.
} 
personalidade humana só pode desenvolver-se agindo. Mas agir significa sempre uma interação ativa na sociedade". ${ }^{171}$ Em Goethe, todos os problemas do humanismo brotam "de circunstâncias concretas da vida, das vivências concretas de seres humanos determinados". ${ }^{172}$ E essa opção estaria em acordo com a extraordinária consciência que tinha o escritor sobre a importância da orientação para o desenvolvimento humano, mas pautado ainda em valores iluministas.

Nesse ponto de sua análise, Lukács faz contundente defesa da obra de Goethe, ao localizá-la no que chamou de "produto de uma crise de transição". Ou seja, o romance foi escrito quando a concepção de mundo pela sociedade burguesa ainda era incipiente, de modo que deixava entrever as contradições entre o humanismo e a sociedade capitalista. "Desse modo, Wilhelm Meister está ideologicamente na fronteira entre duas épocas: dá forma à crise dos ideais humanistas burgueses, ao início de sua superação provisoriamente utópica - do marco da sociedade burguesa." 173

Por isso, as personagens do romance de Goethe "estão agrupadas de um modo praticamente exclusivo em torno da luta pelo ideal do humanismo, em torno da questão dos dois extremos falsos: o sentimentalismo e o praticismo". ${ }^{174}$ Aspecto, até certo ponto, também defendido por Bakhtin, ao afirmar que em romances como Gargantua, Pantagruel e Wilhelm Meister, a formação do homem já não é mais assunto particular:

O homem se forma ao mesmo tempo em que o mundo, reflete em si mesmo a formação histórica do mundo. $\mathrm{O}$ homem já não se situa no interior de uma época, mas na fronteira de duas épocas, no ponto de passagem de uma época para outra. Essa passagem efetua-se nele e através dele. Ele é obrigado a tornar-se um novo tipo de homem, ainda inédito. ${ }^{175}$

\footnotetext{
${ }^{171}$ LUKÁCS, George. Posfácio, In: GOETHE, Johann Wolfgang Von. Os anos de aprendizado de Wilhelm Meister, de Johann Wolfgang von Goethe. São Paulo: Editora 34, 2009, p. 583.

${ }^{172}$ Idem, p. 598.

${ }^{173}$ Idem, p. 598.

${ }^{174}$ Idem, p. 601.

${ }^{175}$ BAKTHTIN, Mikhail. Estética da criação verbal. São Paulo: WMF Martins Fontes, 2010, p. 203.
} 


\subsection{O processo formativo de André e Teobaldo}

$\mathrm{Na}$ literatura brasileira oitocentista, diferentemente do que pode ser constatado nos países europeus no mesmo período, o romance de formação não encontrou ressonância. Como bem sintetiza Wilma Patricia Mass:

Se na literatura europeia o conceito de Bildungsroman, a despeito de todas as suas variações e diferentes abordagens críticas, constituiu-se em pedra angular, em referência prolífica e essencial na história da narrativa, tendo mesmo suas origens confundidas com a própria origem do romance como gênero, na literatura de língua portuguesa, mais especificamente na nacional do Brasil, o conceito permaneceu como referência erudita e pouco produtiva. ${ }^{176}$

No caso brasileiro, até o presente momento $O$ Ateneu $^{177}$ é dos poucos romances do XIX analisado nessa perspectiva, inclusive por Marcus Vinicius Mazzari. ${ }^{178}$ Todavia, a nosso ver, a obra $O$ Coruja enquadra-se em tal categoria, ainda que Aluísio Azevedo tenha lançado mão de aspectos do grotesco para escrever uma espécie de "antirromance" de formação, como veremos no próximo capítulo. Por ora, tentaremos argumentar por que acreditamos que o romance por nós escolhido para análise pode ser incluído em tal categoria.

É comum, nesse tipo de narrativa, o nome do protagonista dar título à obra, como por exemplo Emílio (Jean-Jacques Rousseau), Os anos de aprendizagem de Wilhelm Meister (Goethe), Parcival (Eschenbach), As aventuras de Telêmaco (François Fénelon), Jean Christophe (Romain Rolland), David Copperfield (Charles Dickens) Sidarta (Herman Hesse), Confissões do impostor Félix Krull (Thomas Mann), só para citar alguns.

No caso de $O$ Coruja, o romance é titulado com um apelido. Mais que isso, a coruja está entre aqueles animais que, segundo Kayser, enquadram-se na categoria dos

\footnotetext{
176 MASS, Wilma Patricia. O cânone mínimo: o bildungsroman na história da literatura. São Paulo: Unesp, 1999, p. 244.

${ }^{177}$ Em artigo publicado na revista Remate de Males, Fábio Lucas já aponta para a possibilidade da leitura da obra $O$ Ateneu "Como nosso bildungsroman de maior expressão nacional". LUCAS, Fábio. As várias faces de Raul Pompéia. Remate de Males. Campinas: Unicamp, 1995, n. 5, p. 17-8.

${ }^{178}$ Referimo-nos ao ensaio "Um ABC do terror": representações literárias na escola. In: Labirintos da aprendizagem. São Paulo: Editora 34, p. 159-196.
} 
preferidos pelo grotesco, ao lado de outros bichos noturnos, como as serpentes, os sapos e as aranhas, ou seja, "aqueles que vivem em ordens diferentes, inacessíveis ao homem", ${ }^{179}$ o que já aponta para o caráter antitético do romance. Portanto, já de saída poderíamos dizer que, ao nomear seu suposto romance de formação com um título que nos remete ao universo do grotesco, Aluísio nos dá a possibilidade de leitura da obra em uma perspectiva diferente da tradição do Bildungsroman.

Acreditamos ainda que o processo de formação de André e Teobaldo no internato pode ser enquadrado na segunda categoria apresentada por Bakhtin. Aquela que diz respeito ao "romance didático-pedagógico", baseado com maior ou menor amplitude no processo pedagógico no sentido restrito do termo, que, como veremos, compreende tanto as ações ambientadas no colégio interno, como as ideias pedagógicas defendidas por André, quando se torna professor.

Pode-se dizer que o processo escolar de André tem início antes de sua entrada no internato. Padre João Estevão - seu tutor desde que perdera a mãe, quando tinha 4 anos - será seu primeiro professor. Mas a grande dificuldade de aprender as lições mais simples, somada à ineficiência do pároco em ensinar, recorrendo sempre aos berros e às punições durante as lições, faz com que, aos 10 anos, o garoto seja encaminhado a um colégio interno.

Na primeira aparição do Dr. Mosquito, diretor da instituição onde André continuará seus estudos, já fica evidente seu pouco entusiasmo em acolher um garoto órfão que lhe renderá muito pouco, pois o padre lhe pagará somente meia pensão pela permanência de André em sua renomada escola. Importante dizer também que o desinteresse por seu protegido era tal que padre Estevão sequer se dá ao trabalho de acompanhá-lo ao internato, passando tal incumbência a um senhor idoso, de barbas longas, que não chega a ser é nomeado pelo narrador.

Após sua matrícula, André é literalmente esquecido em um cômodo contíguo à sala do diretor, de onde seu primeiro contato com o mundo escolar se dá apenas por intermédio do que ouve através das paredes:

Pouco depois de entrar para a saleta, um forte rumor de vozes e

${ }^{179}$ WOLFGANG, Kayser. O grotesco. São Paulo: Perspectiva, 2003, p. 157. 
passos repetidos lhe fez compreender que alguma aula havia terminado; daí a coisa de cinquenta minutos, o toque de uma sineta lhe trouxe à ideia o jantar, e ele verificou que se não enganara no seu raciocínio com o barulho de louças e talheres que faziam logo em seguida. Depois, compreendeu que era chegada a hora do tal recreio porque ouvia uma formidável vozeria de crianças que desciam para a chácara. ${ }^{180}$

Como se não bastasse essa situação de exclusão do universo escolar já no primeiro dia de aula, é punido injustamente ao defender-se de Fonseca, um condiscípulo que lhe dá um pontapé ao perceber que ele não revida ao receber o apelido de Coruja.

A despeito de todas essas adversidades iniciais, André estuda com afinco e tem sempre a lição na ponta da língua. A frieza e a sobriedade com que trata todos da comunidade escolar, somadas à sua afeição pelos fracos e indefesos, acabaram impondo certo respeito. E assim transcorre o primeiro ano no internato, durante o qual sua única amizade é com um criado do colégio, Militão, que está sempre às voltas com uma flauta, "dentro da qual soprava ele o velho repertório das músicas de seu tempo. Foi essa miserável flauta que acordou no coração de André o gosto pela música". ${ }^{181}$

Mesmo sem ter significativo conhecimento sobre a matéria, o funcionário do internato dispõe-se a dar ao garoto lições rudimentares de flauta e "lá passavam as últimas horas da tarde, a duelarem-se furiosamente com as notas mais temíveis que um instrumento de sopro pode dardejar contra a paciência humana". ${ }^{182}$ É dessa maneira que André tem seu único contato com a manifestação artística que exercitará até o final do romance. Sobretudo porque, ainda na infância, ganha de Teobaldo uma flauta e um compêndio de música. E esse instrumento será usado por ele, anos depois, para entreter Branca, a esposa do amigo, ainda que toque sempre de maneira medíocre.

A formação artística também pode ser considerada aspecto importante no processo de desenvolvimento do indivíduo, contudo diferente de Meister, que chega a ter relativo sucesso como ator, ou de Jean Christophe, que se torna um músico, apesar

\footnotetext{
${ }^{180}$ AZEVEDO, Aluísio. O Coruja . São Paulo: Livraria Martins Editora, 1963, p. 22.

181 Idem, p. 27.

182 Idem, p. 28.
} 
de todas as adversidades, só para citar dois exemplos, a atuação de André no âmbito artístico sempre vai resvalar na mediocridade. Tanto devido à sua inépcia para tocar um instrumento, como pelo repertório popular que aprende com o funcionário do colégio, seu instrutor. Para elucidar o pouco prestígio da música popular nesse período, podemos nos valer das palavras de José Miguel Wisnik:

Tradicionalmente, um dos nós da questão na música esteve na separação, levada a efeito pelos grupos dominantes, entre a música "boa" e a música "má", entre a música considerada elevada e harmoniosa, por um lado, e a música considerada degradante, nociva e "ruidosa", por outro. Na verdade, isso se deve a que a própria ideia de harmonia, que é tão musical, aplique-se desde longa data à esfera social e política, para representar a imagem de uma sociedade cujas tensões e diferenças estejam compostas e resolvidas. Do ponto de vista dominante, a contestação e a diferença aparecem como "ruídos", como cacófatos sociais, como dissonâncias a serem recuperadas segundo um código ideológico no qual muitas vezes a música oficial figura como sendo a demonstração "natural". ${ }^{183}$

Nos capítulos que transcorrem no ambiente escolar, não há quase nenhuma alusão às matérias estudadas ou à relação entre professores e alunos. No caso de André, sabemos tratar-se de aluno aplicado e, além do já mencionado estudo de flauta, tem permissão do diretor para ajudar o hortelão durante as primeiras férias que passa na escola. Adquire, assim, certo conhecimento prático, intercalado com as horas que, graças à sua autodisciplina, dedica às lições escolares.

Outro dado da formação a ser destacado é o primeiro contato de André com a biblioteca. O recinto está sempre fechado e é uma espécie de objeto de desejo que o menino cobiça: "Ele a rondava como um gato que fareja o guarda-comida; parecia sentir de fora o cheiro do que havia de mais apetitoso naquelas estantes, e, por seu maior tormento, bastava trepar-se a uma cadeira e espiar por cima da porta, para devassar perfeitamente a biblioteca". ${ }^{184}$ Até que, surpreendido pelo diretor, tem permissão para cuidar dos livros. Contudo, franqueada sua entrada naquele espaço,

\footnotetext{
${ }^{183}$ WISNIK, José Miguel. Algumas questões de música e política no Brasil. In: BOSI, Alfredo (Org.). Cultura brasileira: temas e situações. São Paulo: Ática 2006, p. 115.

${ }^{184}$ AZEVEDO, Aluísio. O Coruja. São Paulo: Livraria Martins Editora, 1963, p. 27.
} 
passa o metódico André a dedicar todo seu tempo a limpar e catalogar os livros, em vez de fruir das possibilidades de leitura e dos ensinamentos que deles poderia auferir:

\begin{abstract}
Afigurava-se-lhe que, catalogando todos aqueles livros num só, vêlos-ia disciplinados e submissos ao seu governo. Entendeu que, por esse meio, tê-lo-ia a todos debaixo da vista, arregimentados na memória, podendo evocá-los pelos nomes, cada um por sua vez, como o inspetor do colégio fazia a chamada dos alunos ao abrir das aulas. $^{185}$
\end{abstract}

Assim, desde a mais tenra idade, André é colocado entre as possibilidades de formação e a inviabilidade de seu processo se dar de maneira plena: seu jeito taciturno impede-o de cair nas graças do padre e ser educado por ele; não consegue aprender a tocar flauta, ainda que medianamente, como sempre fora seu desejo; quando tem os livros da biblioteca ao seu alcance, e poderia aproveitar a oportunidade para investir na sua formação, devido ao seu caráter metódico, dedica todo o seu tempo organizando um catálogo que não terá serventia alguma. Portanto, não consegue dar o salto necessário entre o levantamento de dados e a análise necessária para a compreensão de determinado assunto ou realidade. Claro que nesses anos de colégio interno, André ainda era muito jovem para isso, mas veremos adiante que esse continuará a ser o embate enfrentado por ele quando tentar escrever a história do Brasil.

No que diz respeito ao quarto agrupamento apontado por Bakhtin - aquele no qual estariam os romances em que o processo de educação determina o curso da narrativa -, podemos apontar também para as preocupações pedagógicas de André quando se torna professor. Seu desejo era montar uma escola moderna, onde pudesse colocar em prática suas ideias pedagógicas:

[...] um colégio sem castigos corporais, sem terrores; um colégio enfim talhado por sua alma compassiva e casta; um colégio onde as crianças bebessem instrução com a mesma voluptuosidade e com o mesmo gosto com que em pequeninas bebiam o leite materno.

Sem ser um espírito reformador, o Coruja sentiu, logo que tomou conta de seus discípulos, a necessidade urgente de substituir os

${ }^{185}$ AZEVEDO, Aluísio. O Coruja. São Paulo: Livraria Martins Editora, 1963, p. 30. 
velhos processos adotados no ensino primário do Brasil por um sistema todo baseado em observações psicológicas e que tratasse principalmente da educação moral das crianças; sistema como o entendeu Pestallozzi, a quem ele mal conhecia de nome. Froebel foi quem veio afinal acentuar no seu espírito essas vagas ideias, que até aí não passavam de meros pressentimentos. ${ }^{186}$

E aqui nos cabe fazer mais uma aproximação com Wilhelm Meister. Nessa obra, percebe-se que Goethe tinha grande preocupação com a orientação e $\mathrm{o}$ desenvolvimento humano, daí a importância das premissas pedagógicas que norteiam todo o trabalho dos membros da torre. Trata-se de uma educação peculiar, em desacordo com os padrões da época, pois, por meio dela, os indivíduos eram estimulados a desenvolver suas potencialidades de maneira livre e espontânea. A despeito de a educação escolar não ser o tema central da obra de Goethe, essa questão é bem colocada pelo abade, espécie de mentor da Sociedade da Torre: “[...] ao se pretender fazer algo pela educação do homem, devia-se considerar para onde tendem suas inclinações e seus desejos". ${ }^{187}$

No entanto, no romance de Goethe, essa espécie de projeto pedagógico não escolarizado foi executado pelo menos parcialmente, tanto no processo de formação do protagonista e de seus colegas, como no trabalho realizado por Natalie e Therese, com as crianças que têm sob sua orientação. Já o sonho de André de comprar um colégio, onde colocaria em prática suas ideias educacionais, jamais se concretizará. Isso porque, apesar de sua dedicação como professor nos colégios onde leciona e de todas as economias que consegue fazer, quando adquire um estabelecimento de ensino é incapaz de mantê-lo, pois gasta todo o dinheiro capitalizado para pagar, mais uma vez, as dívidas de Teobaldo.

Vejamos agora como se dá a formação de Teobaldo. Essa personagem entra na narrativa no quarto capítulo, e já no terceiro parágrafo o narrador sinaliza que em tudo sua figura contrastava com a de André, não só pela beleza, inteligência e riqueza, como pelo tratamento diferenciado que recebia por parte dos professores, que sempre o

\footnotetext{
${ }^{186}$ AZEVEDO, Aluísio. O Coruja. São Paulo: Livraria Martins Editora, 1963, p. 121.

${ }^{187}$ LUKÁCS, George. Posfácio. In : GOETHE, Johann Wolfgang Von. Os anos de aprendizado de Wilhelm Meister. São Paulo: Editora 34, 2009, p. 403.
} 
protegiam e bajulavam.

Desde que fora defendido em uma briga no pátio por André, o que acaba levando os dois para o castigo, faz dele seu único amigo e confidente, para quem relata sua vivência nos colégios de Londres e Coimbra, onde estivera desde os 6 anos.

Impressões sobre a educação de Teobaldo também são dadas por Hipólito, noivo da tia do garoto:

- Deus queira que não venham a amargar mais tarde! dizia Hipólito, cheio de repreensão. Nunca vi em dias de minha vida semelhante gênero de ensino! Pois se até o fedelho trata aos pais por tu, como se estivesse a falar com os negros! Enfim cada um faz o que entende; eu, porém, tenho o direito de achar bom ou mau. ${ }^{188}$

No caso de André, não há nenhum trauma inicial, tão comum nos romances que transcorrem no internato, e do qual Sérgio, narrador de $O$ Ateneu, é um bom exemplo. A frase célebre do pai da personagem de Raul Pompéia “- Vais conhecer o mundo", já prenunciando os sofrimentos que serão vividos pelo garoto ao trocar o aconchego materno pelo inóspito espaço do internato, e que é tão bem tratado no artigo de Alfredo Bosi $^{189}$-, está longe de fazer sentido para o órfão André. Aliás, quando o padre lhe pergunta se sentirá saudade dele, a resposta do taciturno garoto é taxativa: - Não.

Marcus Vinicius Mazzari, ${ }^{190}$ em estudo comparado no qual faz significativas aproximações entre $O$ Ateneu e As atribulações do pupilo Törles, de Musil, discorre sobre a dificuldade de os protagonistas dessas histórias travarem amizade duradoura no espaço opressor dos colégios internos. Não é o que temos no caso da obra aluisiana. Assim como Sérgio e Rebelo, personagens de O Ateneu, a amizade entre Teobaldo e André tem início quando esse último o protege em uma briga, mas essa relação amical se estenderá por todo o romance, ainda que sofra transformações.

A nosso ver, é justamente esse encontro duradouro entre dois garotos tão diferentes que não apenas impede o trauma inicial, como promove uma espécie de

\footnotetext{
${ }^{188}$ AZEVEDO, Aluísio. O Coruja. São Paulo: Livraria Martins Editora, 1963, p. 57.

${ }_{189}$ O referido ensaio encontra-se na obra Céu, inferno. São Paulo: Duas Cidades /Editora 34, p. 51-86.

${ }^{190}$ MAZZARI, Marcus Vinicius. Labirintos da aprendizagem. São Paulo: Editora 34, p. 159-196.
} 
proteção recíproca contra a violência tão presente nos romances do período, ambientados no colégio interno, ${ }^{191}$ pois, ao se aproximar de André, Teobaldo lhe proporciona uma sensação de afeto até então nunca sentida, o que, em certa medida, contribui para que o órfão já não se perceba tão abandonado no mundo. Em contrapartida, por ser fisicamente mais forte, André protegerá o amigo das situações de violência e do constrangimento tão comuns nesses espaços. Além de ajudá-lo nas tarefas maçantes e até cumprir os castigos impostos a ele pelos professores.

No referido ensaio, Marcus Vinicius Mazzari aponta o papel de bode expiatório que Franco tem na obra pompeiana: "Franco é, por assim dizer, o bode expiatório institucionalizado do estabelecimento, oprimido não só pelos outros internos, mas principalmente por Aristarco". ${ }^{192}$ Até certo ponto, André também exerce esse papel no internato, mas tanto a relação de amizade com Teobaldo, como sua forma de ver o mundo, protegeram-no naquele ambiente opressor. Ainda que o Dr. Mosquito - assim como Aristarco fizera com Franco - inúmeras vezes tenha tentado subjugá-lo por meio de castigos ou humilhá-lo diante dos colegas, por comer muito e pagar pouco, André não se deixa constranger e o trata com a mesma frieza de gestos que dispensava aos colegas, à exceção de Teobaldo. E aqui nos cabe lembrar que o pequeno inseto, que dá nome ao diretor, é também alimento das corujas. Essa escolha de Aluísio Azevedo para nomear suas personagens não deve ter sido gratuita.

No entanto, não é apenas no colégio onde podemos observar elementos concernentes à formação dos dois amigos. Durante as férias, André é convidado a passar uma temporada na fazenda dos pais de Teobaldo, e ali o narrador continua a nos fornecer informações a respeito de ambos. Enquanto Teobaldo tinha verdadeira predileção pela busca de aventuras, André estava sempre às voltas com alguém que pudesse lhe ensinar o nome de uma planta, como era feito o plantio de determinado cereal e a melhor época para a colheita. André aproveitava o sossego dos vales para ler suas obras prediletas, entre elas Robinson Crusoé, ${ }^{193}$ enquanto seu amigo só desejava

\footnotetext{
${ }^{191}$ Marcus Vinicius Mazzari aponta para a violência na prosa ambientada nos colégios, sobretudo na literatura alemã por volta de 1900. "Esta aparece como um espaço de sofrimento e horror, em que a consciência do dever, disciplina e obediência valem como os valores mais elevados." MAZZARI, Marcus Vinicius. Labirintos da aprendizagem. São Paulo: Editora 34, p. 161.

192 MAZZARI, Marcus Vinicius. Labirintos da aprendizagem. São Paulo: Editora 34, p. 174-5.

${ }^{193}$ Wilma Patricia Mass observa que a origem do processo de estabelecimento do Bildungsroman também
} 
da floresta "aquilo que ela lhe pudesse dar de imprevisto e venturoso."194

O processo de formação dos amigos continua na segunda parte do romance. Uma vez instalados na Corte, é preciso que Teobaldo escolha o que estudar. E aí, em uma conversa que tem com André, evidencia-se sua dificuldade em escolher uma carreira. $\mathrm{O}$ que pode ser resumido na frase dita por ele ao final desse diálogo: "Entendo um pouco de desenho, um pouco de música, de canto, de poesia, de arquitetura, mas sinto-me tão incapaz de apaixonar-me por qualquer dessas artes. Tudo me atrai; nada, porém, me prende!"195 Apesar dessa dificuldade de escolher o que estudar, três manifestações artísticas são recorrentes na formação de Teobaldo: a música, a poesia e o teatro.

Com relação à música, podemos exemplificar com a cena armada pelo narrador para a apresentação de Branca, futura esposa de Teobaldo. Antes de conhecer sua pretendida, ele conversa com a preceptora da jovem, Mme. De Nangis, ${ }^{196}$ a quem revela amar apaixonadamente a música e que toca piano. Já tendo conquistado a afeição daquela que, ele sabe, tem sobre a moça grande influência, seguem para outra sala, onde "duas rabecas, uma violeta e um violoncelo dispunham-se a executar uma serenata de Schubert". ${ }^{197}$ Em pouco tempo, sem exageros e frases pretensiosas, mas elegante e distinto, medindo as frases e os gestos, como bem prescreve sua educação aristocrática, Teobaldo passa a ser o centro das atenções de todas as damas, inclusive de Branca.

Como dramaturgo, Aluísio Azevedo certamente tinha bons conhecimentos sobre a música produzida no seu tempo. Portanto, não foi por acaso que escolheu uma peça do romântico Schubert para servir de fundo musical para o primeiro encontro entre Teobaldo e Branca. O narrador não explicita que peça do músico vienense serve de fundo musical para o primeiro encontro do casal, mas Otto Maria Carpeaux nos informa que foi Schubert o "maior poeta lírico da música". Grande criador de lieds, compôs cerca de 600, "entre os quais há muita coisa ligeira, música de sociedade,

pode ser encontrada nos livros de aventura na Europa do século XVIII. "O exemplo mais significativo e legitimador dessa tese é a recepção de Robinson Crusoé, de Defoe, no espaço literário alemão na época." MASS, Wilma Patricia. O cânone mínimo: o Bildungsroman na história da literatura. São Paulo: Unesp, 1999 , p. 77.

${ }^{194}$ AZEVEDO, Aluísio. O Coruja. São Paulo: Livraria Martins Editora, 1963, p. 58.

195 Idem, p. 82.

196 Idem, p. 191.

${ }^{197}$ Idem, p. 191. 
alegre, mas sempre bonita e às vezes de beleza sedutora". ${ }^{198}$

Se estamos de acordo que a arte tem função importante nos processos formativos, para André a proximidade com a música deu-se ao acaso e seu aprendizado ocorreu de maneira fortuita, pelas mãos de um homem que pouco entendia da matéria; no caso de Teobaldo, saber música, e sobretudo música clássica, fazia parte da formação aristocrática por ele recebida desde a infância. Ainda que essa manifestação artística não seja usada em compartilhamento estético com o coletivo, mas apenas para seduzir as mulheres que farão parte de sua educação sentimental. Além de tocar para Branca durante o namoro e primeiros anos de casamento, o piano é citado com frequência durante o processo de sedução de d. Ernestina, proprietária da casa onde os rapazes moraram nos primeiros anos na Corte.

Em Wilhelm Meister, a opção pelo teatro evidencia-se como a única alternativa possível para um burguês que deseja alcançar o mesmo patamar de formação inerente à aristocracia. Diferentemente da personagem de Goethe, Teobaldo não consegue se fixar em nenhuma atividade artística, ainda que em vários momentos do romance a personagem explicite seu desejo de dedicar-se ao teatro e fazer-se ator. Contudo, o excesso de diletantismo não o deixa sequer iniciar-se nessas carreiras, e é com muito custo que acaba decidindo-se pelo curso de Medicina.

$\mathrm{Na}$ juventude chega a ver uma peça sua encenada, mas quando realmente se dispõe a escrever para o teatro com o intuito de ganhar dinheiro como dramaturgo, todas as portas lhe são fechadas. Depois de alguns anos, já casado com Branca, quando ocupa lugar de destaque na Corte, por várias vezes representa personagens durante os saraus e, tão bem copiava determinado ator, que chegaram a julgá-lo com dom para a arte dramática. Mas esse talento aparece diluído entre tantos outros que aparenta ter, em uma sociedade dada às novidades de ocasião.

Durante o período em que precisa encontrar meios para se sustentar, o jovem até se esforça para adaptar um romance inglês para o teatro "que, se não era um primor de arte, estava ao menos ao gosto do público e podia dar lucro". ${ }^{199}$ Mas os mesmos

\footnotetext{
${ }^{198}$ CARPEAUX, Otto Maria. O livro de ouro da História da música: da Idade Média ao Século XX. Rio de Janeiro: Ediouro, 2009, p. 226.

199 AZEVEDO, Aluísio. O Coruja. São Paulo: Livraria Martins Editora, 1963, p. 119.
} 
empresários que meses antes o haviam elogiado, receberam-no com frieza, fazendo com que ele logo desistisse da carreira teatral. E para justificar essa lassidão de vontade, o narrador lança mão do determinismo da hereditariedade, que grassava nos romances naturalistas da época, como podemos constatar na seguinte passagem:

Passadas as primeiras épocas depois da morte dos pais de Teobaldo, o verdadeiro temperamento deste, aquele temperamento herdado do velho cavalheiro português e da cabocla paraense, aquele temperamento mestiço agravado por uma educação de mimos e liberdades sem limites, começou a ressurgir como o sol depois de uma tempestade. ${ }^{200}$

É interessante observar que o narrador não se refere apenas aos laços sanguíneos de Teobaldo, mas também à má educação que recebera por parte dos pais, por demais condescendentes. Em outra passagem chega-se a afirmar que a dificuldade de Teobaldo em dedicar-se a uma profissão devia-se à "fatalidade de seu temperamento e de sua educação". 201

Mas em muitos trechos da segunda parte do romance, como a apresentada a seguir, presenciamos a intervenção de um narrador que aponta para o sofrimento do jovem diante de sua dificuldade em se firmar profissionalmente, já sinalizando para a amargura que vai assolá-lo nas últimas páginas do livro: "Entretanto Teobaldo sofria e sofria muito. Só quem já atravessou uma quadra de necessidade, quando se tem o estômago mal confortado e o coração cheio de orgulho, poderá julgar o desgosto profundo e o tédio homicida que o acompanhavam". ${ }^{202}$

Quando parece começar a empenhar-se em sua formação acadêmica, ele recebe ao mesmo tempo duas notícias terríveis: a morte da mãe e a falência do pai, que terá de hipotecar a fazenda para pagar as dívidas. É quando decide largar os estudos e procurar emprego, do que é dissuadido por André: "- O meu caso é muito diverso; sou de poucas aspirações, não desejo ser mais do que um simples professor; tu, porém, tens direito a muito, e aqui em nossa terra a carta de doutor é a chave de todas as portas das

\footnotetext{
${ }^{200}$ AZEVEDO, Aluísio. O Coruja. São Paulo: Livraria Martins Editora, 1963, p. 121.

${ }^{201}$ Idem, p. 122.

${ }^{202}$ Idem, p. 159.
} 
boas posições sociais". ${ }^{203}$

Certo apego à frase sonora e textos escritos com excesso de adjetivos e floreios contribuíram para que Teobaldo conseguisse alguma expressão nos jornais da Corte, mas sempre esteve longe de alcançar qualquer projeção como poeta ou dramaturgo, bem diferente do caso de Meister, o protagonista de Goethe, pois, se Teobaldo cultivava as letras, não era porque estivesse apaixonado pela arte de escrever, "mas pelo simples gosto de ter seu nome em circulação". ${ }^{204}$

Pelo visto até aqui, os caminhos percorridos pelos dois amigos nos permitem situar $O$ Coruja na categoria do romance de formação, ainda que a obra esteja bem longe do protótipo goethiano. No caso de André, ao final de sua formação especializada, torna-se um professor empenhado no seu ofício, cumprindo então uma das premissas estabelecidas pelo ciclo formativo que se fecha: aprender para depois compartilhar o conhecimento com o social. No entanto, como veremos no último capítulo deste estudo, se tornará um homem frustrado, justamente porque, a despeito de exercer tanto o papel de professor, como a função de revisor, com empenho, o excesso de trabalho e as frequentes desilusões que sofrerá farão dele um indivíduo triste e amargo.

Quanto a Teobaldo, também não há dúvida de que tinha tanto os recursos financeiros como talentos que poderiam ter sido usados em prol de sua formação. Mas diferentemente de Meister, que se distancia das atividades práticas que lhe eram auferidas por sua condição de filho de comerciante burguês, e deixa a proteção familiar em busca do desenvolvimento de suas potencialidades latentes, Teobaldo jamais abrirá mão da situação de filho de fazendeiro. Parte para a Corte para estudar, como era comum aos filhos da aristocracia rural, mas não desenvolverá os vários talentos que possuía, afastando-se bastante do modelo goethiano.

No entanto, malgrado a dificuldade em dedicar-se a qualquer ofício, graças à sua origem aristocrática e às relações sociais, muitas vezes escusas, que estabelece com pessoas do seu meio, torna-se um político eminente, mas um homem infeliz, que, no final do romance, se conscientiza de sua mediocridade. Justamente porque não havia

\footnotetext{
${ }^{203}$ AZEVEDO, Aluísio. O Coruja. São Paulo: Livraria Martins Editora, 1963, p. 114.

${ }^{204}$ Idem, p. 110.
} 
em nada do que realizava a "menor sombra de amor pelo trabalho, nem desejo de ser útil à pátria ou aos seus semelhantes, mas só à vaidade". ${ }^{205}$

\section{4. O processo formativo de Inês e Branca}

Apesar de nosso foco ser o processo formativo de André e Teobaldo, vale fazer algumas observações sobre a formação de duas mulheres que figuram no romance, Inês e Branca, antes de tratarmos da educação sentimental dos jovens amigos.

D. Margarida, viúva que ganhava a vida como lavadeira, é quem nos informa sobre a escolaridade da filha, Inezinha, que fora colocada no colégio contra a vontade do pai: “- Aí está, resmungava a mãe; aí está para que serviu saberes mais do que eu! Bem dizia teu pai, a quem Deus haja; bem dizia ele, quando te pus no colégio, que nada havíamos de lucrar com isso!"206

Por meio dessa discussão que tem com a filha, em que d. Margarida se diz arrependida de ter lhe permitido estudar, pois isso a fizera inepta para os afazeres domésticos e não lhe dera temperamento para usar o ferro de engomar, podemos inferir algumas informações sobre a educação das meninas à época. Vendo que a filha não tinha nenhum talento para ganhar dinheiro como lavadeira ou costureira, ocorre-lhe que a jovem possa lecionar para as crianças da vizinhança. A moça se sai tão bem nessa atividade, que, em pouco tempo, d. Margarida alenta a possibilidade de que Inezinha arranje uma cadeira como professora régia.

Temos, nessa passagem do romance, dados importantes sobre as possibilidades de trabalho para moças nascidas nas condições sociais de Inês, na época em que se passa a história. Poderia ser lavadeira, função que o próprio Aluísio Azevedo retratou tão bem em $O$ cortiço, ou prestar serviços como costureira. Se por ventura tivesse a sorte de frequentar o colégio, caso da noiva de André, outra função possível seria dar aulas particulares em casa e, se seus pais assim o permitissem, teria a jovem o

\footnotetext{
205 AZEVEDO, Aluísio. O Coruja. São Paulo: Livraria Martins Editora, 1963, p. 257.

${ }^{206}$ Idem, p. 94.
} 
magistério como possibilidade de trabalho fora do ambiente doméstico. ${ }^{207}$

Contudo, ainda que, com a ajuda das aulas recebidas do prestimoso André, a jovem tenha conseguido concluir seus estudos e se visse preparada para reger uma cadeira de primeiras letras, suas aspirações não se concretizaram. Inezinha continuará a dar aulas em casa até que, cansada de esperar por um casamento que não se realiza com André, contrai matrimônio com um alferes alcoólatra, o Picuinha, e passa a cuidar da prole que vem a ter com ele.

Se o processo de formação de Inês foi malogrado, o que podemos dizer sobre a educação de Branca? Como vimos anteriormente, antes de conhecer a moça, Teobaldo é apresentado à preceptora dela, a francesa Mme de Nanguis, que, ao que tudo indica, tem um relacionamento amistoso com o pai de sua discípula, então viúvo. Por oito anos ficou ela encarregada da educação da futura esposa de Teobaldo. O narrador faz questão também de mencionar que o pai presenteara a filha com um livro de poemas do romântico Casimiro de Abreu.

Sobre a influência da preceptora na formação da jovem, temos poucas informações. Logo depois do casamento de Branca, e da consequente morte de seu pai, Mme de Nanguis volta para Paris. Mas a última referência que temos dela diz respeito justamente à sua relação com a aluna:

Mme. De Nangris, como toda mãe adotiva, transmitira-lhe as suas maneiras, o seu gosto, o seu estilo, mas não lhe tocara alma, pois essa só a própria mãe sabe educar. Felizmente a alma de Branca era boa por natureza, e se não a aperfeiçoou por falta de educação, também não se corrompeu com a moral da professora. ${ }^{208}$

No decorrer da terceira parte do romance, há inúmeras passagens em que o

\footnotetext{
${ }^{207}$ Guaciara Lopes Louro em interessante estudo sobre a escolaridade das mulheres no oitocentos, escreve o seguinte: "As últimas décadas do século XIX apontam, pois, para a necessidade de educação para a mulher, vinculando-a à modernização da sociedade, à higienização da família, à construção da cidadania dos jovens. A preocupação em afastar do conceito de toda a carga de degradação que lhe era associada por causa da escravidão e em vinculá-lo à ordem e progresso levou os condutores da sociedade a arregimentar as mulheres das camadas populares. Elas deveriam ser diligentes, honestas, ordeiras, asseadas; a elas caberia controlar seus homens e formar os novos trabalhadores e trabalhadoras do país. LOURO, Guaciara Lopes. Mulheres na sala de aula. In: DEL PRIORE, Mary (Org.). História das mulheres no Brasil. São Paulo: Editora da Unesp/Contexto, 2008, p. 447.

${ }^{208}$ AZEVEDO, Aluísio. O Coruja. São Paulo: Livraria Martins Editora, 1963, p. 244.
} 
narrador evidencia o caráter correto de Branca e sua dedicação à casa e ao marido. Mesmo quando perde todas as ilusões em relação a ele, não sucumbe diante da sedução do primo. Ao descobrir que Teobaldo tem várias amantes, e perceber a forma inescrupulosa como ele se apropria das notas de André para escrever seus artigos, afasta-se afetivamente, mas mantém-se socialmente ao lado dele.

O marido, por sua vez, "gozava muito mais com vê-la resplandecer em meio dos salões, crivada de olhares deslumbrados, do que tê-la a sós, na intimidade do lar, palpitante de amor nos braços dele". ${ }^{209}$ E ainda assim, Branca cumpre o papel de esposa exemplar e, se na intimidade o execrava com asco, "não arredava um ponto da linha de seus deveres de mulher casada". ${ }^{210}$

E aqui é conveniente citar trecho de artigo de Maria Angela D'Incao sobre a posição da mulher na família burguesa no Brasil do XIX, que ilustra bem a posição de Branca no romance: "Mulheres casadas ganhavam uma nova função: contribuir para o projeto familiar de mobilidade social através de sua postura nos salões como anfitriãs e na vida cotidiana, em geral, como esposas modelares e boas mães". 211

Portanto, ainda que Branca tenha conseguido contrariar o desejo do pai, que queria casá-la com Aguiar, fugindo com o homem que realmente amava, mantém sua integridade de esposa até a última página do romance. Todavia, acreditamos que longe de querer apenas apregoar as vicissitudes do casamento e da importância do bom proceder da mulher casada, Aluísio concebe uma personagem de caráter tão límpido, como o nome que lhe é dado, para que fique ainda mais evidente a decrepitude moral de Teobaldo no final do romance, questão que aprofundaremos no quinto capítulo.

Vale acrescentar, para fechamento dessa reflexão a respeito de Branca, que, a despeito de ter investido todos os seus esforços nessa relação, como assim prescrevia seu papel de jovem burguesa e casta, capital simbólico importante para que Teobaldo mantivesse seu status de homem político bem-sucedido, ao final da trama, ela torna-se uma mulher infeliz.

\footnotetext{
${ }^{209}$ AZEVEDO, Aluísio. O Coruja. São Paulo: Livraria Martins Editora, 1963, p. 253.

${ }^{210}$ Idem, p. 286.

${ }^{211}$ D' INCAO, Maria Angela. "Mulher e família burguesa". In: DEL PRIORE, Mary (Org.). História das mulheres no Brasil, História das mulheres no Brasil. São Paulo: Editora Unesp/Contexto, 2008, p. 229.
} 


\section{5. A educação sentimental de André e Teobaldo}

Ainda que aspectos da formação educacional estejam presentes no livro, questões que, como vimos, não ficam restritas à primeira parte do romance, há outro elemento concernente à formação que permeia toda a narrativa: a educação sentimental.

No caso de André, podemos dizer que, apesar de o namoro com Inezinha ter sido um arranjo de d. Margarida, com o passar do tempo o tímido professor se afeiçoa à moça, como se pode constatar na passagem transcrita abaixo:

Coruja, fácil como era para se escravizar aos hábitos, no fim de algum tempo já não podia passar sem aqueles calmos serões à luz do velho candeeiro de D. Margarida; já não podia dispensar a xicarinha de café, que ele ouvia moer no pilão, no quintal; e precisava sentir ao seu lado, durante aquelas horas certas, o vulto passivo e silencioso de Inez. Seu coração imaculado e casto foi pouco a pouco se deixando vencer por um sentimento até aí desconhecido para ele. ${ }^{212}$

E o que começara apenas como um hábito, do qual o metódico André não conseguia mais se afastar, vai ganhando outros contornos no coração do professor: "Era um amor muito transparente, muito calmo, que esperava com evangélica paciência o dia da ventura, sem a mais ligeira perturbação dos sentidos." ${ }^{213}$ Como sua bondade extrema e seu caráter irrepreensível o levassem com frequência e esquecer-se de si mesmo, não pode ficar indiferente ao fato de ter uma noiva e chega a dizer: "- Eu também tenho uma mulher que me ama!". A esse "também", que certamente refere-se ao fato de ver o amigo Teobaldo sempre cercado por mulheres que o adoram, vem a intervenção do narrador com uma pergunta mordaz: “Ama-lo-ia?”, para concluir: “Talvez não; mas o que para qualquer outro não passava de simples afabilidade vulgar e obrigada, para ele era a extrema manifestação da ternura feminil, tão habituado estava à indiferença e ao desamor dos seus semelhantes". ${ }^{214}$

Entretanto, aquele ser estoico e pouco afeito aos prazeres da carne e à

\footnotetext{
${ }^{212}$ AZEVEDO, Aluísio. O Coruja. São Paulo: Livraria Martins Editora, 1963, p. 96.

${ }^{213}$ Idem, p. 96.

${ }^{214}$ Idem, p. 171.
} 
sensualidade, que pela primeira vez vê a possibilidade de ter uma companheira ao seu lado, vislumbra uma reflexão acerca do possível encontro entre a bondade e a felicidade: "Pela primeira vez julgou possível ter uma companheira ao lado de sua vida, e essa ideia o transportou de júbilo; ser bom para todos, indiferentemente, é um gozo, mas ser bom para quem nos retribui os sacrifícios com amor e caridade, isso já é o que se chama a felicidade". ${ }^{215}$

O casamento também era visto como uma possibilidade de dirigir ainda mais suas qualidades morais, dando-lhes um objetivo. Via ainda a possibilidade de a mulher compartilhar com ele "a grandeza exagerada do seu coração". 216

Contudo, a forte predisposição de Inezinha para ser uma "maria vai com as outras", sobretudo quando essa outra é uma mulher autoritária como sua mãe, d. Margarida, somada à protelação da união por parte de André, faz com que o tão alentado casamento não se realize. Assim, André vê sua possibilidade de felicidade matrimonial desfazer-se. E pior, além de não ter o prazer de gozar das delícias desse encontro, se encarregará do fardo de cuidar de Inezinha e sua prole, quando Picuinha é internado, depois de uma crise de loucura acarretada pelo álcool.

Mas, se explicitamente essa é a única experiência sentimental de André, veremos que a maneira como se dá sua intervenção nos assuntos sentimentais de Teobaldo pode nos ajudar a compreender essa intrincada relação de amizade e ampliar nossa visão do que se passava no coração do casmurro professor.

Na primeira parte do romance, André não só será depositário do segredo sobre o primeiro amor de Teobaldo, como acompanhará o amigo em alguns encontros. Amor inocente por Joaninha, filha de um dos posseiros da fazenda do barão de Palmar. Tudo acontece naquelas férias em que André fora convidado a passar a temporada na fazenda dos pais do amigo:

O Coruja foi logo o depositário do segredo; Teobaldo contou-lhe a sua aventura e exigiu que ele o acompanhasse todos os dias à rocinha do João da Cinta, quedando-se a certa distância durante o tempo da

\footnotetext{
${ }^{215}$ AZEVEDO, Aluísio. O Coruja. São Paulo: Livraria Martins Editora, 1963, p.171.

${ }^{216}$ Idem, p. 172.
} 
entrevista. André consentiu, sem mostrar o mais ligeiro espanto pelo que lhe revoltara o amigo. Ainda inocente e deveras casto, não conhecia os meandros do amor e julgava os outros corações pelo seu, que resumia toda a gama do afeto e da ternura em uma nota única. Não calculava a que podia chegar aquele inocente namoro originado entre o filho do Sr. Barão do Palmar e uma sertaneja, que nem ler sabia. $^{217}$

Mesmo que esse namoro não tenha maiores consequências na trama do romance, essa posição de voyeur, que André tem nessa ocasião, de certa maneira se estenderá por toda a narrativa. Paulatinamente seu envolvimento nas confusões em que Teobaldo se mete no percurso de sua educação sentimental, em certa medida, contribuiu também para a formação (ou desilusão) sentimental de André.

Passado esse namoro da infância, a segunda mulher a interferir na formação afetiva de Teobaldo é d. Ernestina. Não se trata nem de uma loureira, como Leonília, nem de uma jovem casta e burguesa, como Branca. Espancada pelo primeiro marido, que a deixara à beira da morte, d. Ernestina é acolhida pelo sr. Almeida, que mantém a casa onde a jovem mulher aluga quartos e fornece refeições. Essas "casas de cômodo" eram muito comuns no Segundo Império e é o locus escolhido por Aluísio Azevedo para ambientar seu romance Casa de pensão, como visto no capítulo 1.

Antes da cena em que Teobaldo é finalmente seduzido, temos vários diálogos entre os dois futuros amantes, nos quais d. Ernestina tenta em vão aliciá-lo, seguida da seguinte intervenção do narrador:

Um homem mais velho que Teobaldo notaria entretanto que Ernestina era bem servida de formas, que tinha bons dentes, cabelos magníficos e um par de olhos bem guarnecidos e banhados de uma certa umidade voluptuosa. Mas o filho do barão estava na idade em que os homens ainda não sabem apreciar as mulheres e aceitam-nas indeterminadamente, como simples recreio dos seus sentidos. Orçava ele então pelos dezoito anos e, mais formoso do que nunca, desenvolviam-se-lhe as feições, sem detrimento da primitiva frescura.

${ }^{217}$ AZEVEDO, Aluísio. O Coruja. São Paulo: Livraria Martins Editora, 1963, p. 67. 
[...] Tez aveludada e pura, sorriso crespo e frio, olhar indiferente e terno a um tempo, dir-se-ia que ele, naquele todo de jovem príncipe aborrecido, realizava com a sua graciosa e pálida figura o tipo ideal do romantismo da época. ${ }^{218}$

Importante notar como o narrador faz questão de associar essa imagem de Teobaldo à figura de um tipo romântico, não só na descrição, mas na afirmação que faz ao final dela. Contudo veremos mais adiante que, a despeito da aproximação física, seu caráter estava longe de ser afinado pelo diapasão romântico.

Como se o rapaz não entendesse suas insinuações, d. Ernestina arma uma situação para seduzi-lo. O quarto estava escuro. Deitada na cama do segundo andar, onde o jovem até então jamais adentrara, ela chora ou finge lamentar a morte de uma tia. Teobaldo tateia pelo ambiente, até se ver diante de uma cama de casal. Ernestina desfalece "onde apenas a cabeça e os braços se lhe viam por entre coberta e lençóis". 219

É André quem dá ao amigo o recado de Ernestina e, ainda que sua inocência não o permita notá-lo, acaba sendo o intermediário da consumação do encontro amoroso. Também é o Coruja quem cuida de Ernestina durante o ataque de histeria, que acaba levando-a ao suicídio.

O casto André ainda tenta convencer Teobaldo a ficar com Ernestina, quando ela vem a se instalar na casa dos rapazes em busca do amor e da proteção de Teobaldo, como mostra trecho do diálogo entre ambos reproduzido a seguir:

- Imagina tu que vinte mulheres pensam do mesmo modo e ao mesmo tempo a meu respeito; algumas, pelo menos, ficarão fatalmente sacrificadas, porque a gente não pode dedicar-se a tantas... E note-se que nenhuma delas admite divisões de ternura; cada uma quer tudo para si e leva o egoísmo a ponto de não consentir que o objeto do seu amor pense em outra pessoa que não seja ela! Ah! É uma bela coisa, não há dúvida!

- Escolhe uma entre todas e dedica-te só a essa. A Ernestina, por

\footnotetext{
${ }^{218}$ AZEVEDO, Aluísio. O Coruja. São Paulo: Livraria Martins Editora, 1963, p. 85-6.

${ }^{219}$ Idem, p. 87.
} 
exemplo...

- Não, não quero Ernestina, como não quero nenhuma. Trata tu de despachá-la, que eu me encarrego das mais. Daqui, vou já principiar a cuidar disso; é preciso não perder tempo. Adeus. ${ }^{220}$

Vale também apontar para a situação embaraçosa em que se vê o recatado André diante de um dos ataques histéricos de Ernestina: "Além de que, a sua nenhuma convivência com mulheres e o seu natural acanhamento, mais penosa e crítica tornavam para ele aquela situação". ${ }^{221}$

A terceira mulher a participar da educação sentimental de Teobaldo é Leonília, uma prostituta refinada que conhecera no teatro: "Teobaldo tratou-a com o mesmo sedutor e natural desinteresse que costumava usar para as mulheres desse gênero; mas depois, quando a conheceu mais de perto e teve ocasião de compulsar-lhe o espírito, principiou a distingui-la entre todas as outras com certa preferência". 222

Nos lençóis de Ernestina, Teobaldo é iniciado no amor sensual, mas é com a loureira, filha de um francês, que refina tanto seu poder de sedução quanto o seu cinismo diante da impossibilidade de corresponder a qualquer sentimento de cunho amoroso. Leonília tenta inúmeras vezes desvencilhar-se do sentimento que nutre pelo amante, mas não consegue. É por meio dos diálogos que tem com ele que acompanhamos a opinião de ambos sobre as diferentes manifestações de amor. Entre eles, o maternal e o filial, que Teobaldo considera legítimos e a moça refuta com argumentos bastante convincentes. Então, o rapaz refere-se ao amor sincero que o amigo André dedica-lhe e da inveja que ele tem daquele ser abnegado e sem vícios.

Em outros momentos, Leonília representa o ideário romântico, em que a redenção da prostituta chega ao extremo. Por exemplo, quando se dispõe a vender seus bens e alugar uma casinha simples, onde pretende dedicar-se apenas ao amado - cena que lembra em muito a redenção de Lucíola, de Alencar. Mas a essa postura romântica opõem-se as ideias bem racionais de Teobaldo sobre o amor:

[...] - apenas sustento que o amor, qualquer que ele seja, não me

\footnotetext{
${ }^{220}$ AZEVEDO, Aluísio. O Coruja. São Paulo: Livraria Martins Editora, 1963, p. 163-5.

${ }^{221}$ Idem, p. 194.

${ }^{222}$ Idem, p. 154.
} 
causa entusiasmo nem admiração de nenhuma espécie. Se não me amasses, amarias a outro; amas-me, não porque eu seja forte, inteligente ou bom. Mas sim por uma razão muito simples - porque és mulher! O caso seria para espantar. Se em vez de te apaixonares por mim, te apaixonasses por uma estátua ou por uma árvore ou por um elefante ou por esta bengala! $!^{223}$

Também nesse caso amoroso, é com a ajuda de André que conta Teobaldo para se desvencilhar da amante, quando pretende casar-se com a filha do Conselheiro. $\mathrm{O}$ Coruja não só toma para si a difícil tarefa de persuadi-la a deixar Teobaldo em paz, como paga as despesas da viagem dela para o exterior. A certa altura do diálogo, tamanho é o empenho de André na empreitada, que a moça chega a pensar que o professor tenciona fazê-la sua amante. E isso o leva a corar de vergonha. É também nessa conversa que temos uma máxima lapidar de uma jovem versada nas coisas do coração e convenções do casamento:

- Não há homem que se não modifique deixando o estado de solteiro! Quando eles até então só amam a mulher com que se casam, mal a possuem esquecem-na por outra; e, se antes do casamento já se dedicavam a qualquer amante, será esta sacrificada à legítima esposa. Esta é a lei geral; esta há de ser a lei de Teobaldo! 224

Todavia, no caso de Teobaldo, ainda que Leonília não volte a ser sua amante depois do casamento com Branca, outras mulheres desempenharão esse papel.

Trataremos finalmente da última mulher que participa da educação sentimental de Teobaldo: Branca. Jovem casta, aparentemente do mesmo nível social de Teobaldo, embora logo depois do casamento ele viesse a saber que o dote da moça não era tão alto quanto supunha. Longe de estar apaixonado, o filho do barão casa-se por interesse. Mas há no discurso de sedução dele um aparente desejo de redenção:

- Ouça-me, acrescentou Teobaldo, segurando-a pelos braços. Ouça e perdoe, minha doce esperança, minha vida! A senhora foi o meu bom anjo, foi a salvadora de minha alma; eu já me sentia perdido, gasto,

\footnotetext{
${ }^{223}$ AZEVEDO, Aluísio. O Coruja. São Paulo: Livraria Martins Editora, 1963, p. 143.

${ }^{224}$ Idem, p. 218.
} 
morto; desde que a vi, reanimei-me como por encanto! Adoro-a, Branca, e basta uma palavra sua, uma única, para que eu seja o mais feliz ou o mais desgraçado dos homens! $!^{225}$

No primeiro ano de casamento, Teobaldo até consegue dedicar-se apenas à esposa, mas sua ambição pelo poder o leva a seduzir a esposa de um conselheiro, que poderia lhe ser útil para abrir um jornal. Veículo fundamental para iniciar sua pretensa ascensão política.

Mesmo sabendo-se traída, Branca jamais cederá ao assédio do primo, Aguiar, e é por meio das repreensões da esposa que Teobaldo, finalmente, cai numa reflexão profunda. Durante essa espécie de arrebatamento diante de uma vida que poderia ter sido mas não foi, a personagem faz a seguinte reflexão sobre a companheira:

\begin{abstract}
Ah! Se eu não tivesse me incompatibilizado com ela!... Se pudesse ir buscá-la, trazê-la aqui para o meu gabinete, desfrutar a sua companhia, gozar o seu coração!... Oh! mas tudo isto já não pode ser! Está tudo perdido! Ela continua a ver em mim um vaidoso, um fátuo, um homem ainda menor que o mais vulgar! Nunca mais poderei ser para Branca o que fui, o que ela me julgou na cegueira do seu primeiro amor! $!^{226}$
\end{abstract}

Como nos casos amorosos anteriores, André não apenas acompanha a felicidade dos primeiros anos de casamento com Branca, mas paga as dívidas que Teobaldo contrai com Aguiar. Em várias situações, o narrador fala da verdadeira adoração que André tinha por Branca e o quanto lhe era aprazível ler trecho de Garrett e Camões para a esposa do amigo. Em nenhum momento, o narrador deixa transparecer qualquer indício de que André desejasse Branca, mas a maneira como descreve o desconcerto do Coruja diante da jovem é bastante significativa:

Ao lado de Branca então chegara o seu acanhamento a causar dó; quando a formosa senhora lhe dirigia a palavra, ele parecia ficar ainda mais selvagem, mais desajeitado, atarantava-se, fazia-se

\footnotetext{
${ }^{225}$ AZEVEDO, Aluísio. O Coruja. São Paulo: Livraria Martins Editora, 1963, p. 202.

${ }^{226}$ Idem, p. 354.
} 
estúpido, não encontrava posição defronte daquele primor de beleza, e conseguia apenas uivar algumas vozes confusas e quase sem nexo. E no entanto sentia por ela um afeto extremamente respeitoso, uma espécie de adoração humilde e tácita; quando Branca passava por junto dele, Coruja reprimia a respiração, contraía-se todo, como se receasse macular o ambiente que ela respirava; e só se animava a encará-la enquanto a tinha distraída ou de costas, e isso com um profundo olhar de terna veneração. ${ }^{227}$

Essa espécie de amor platônico, bem próprio do caráter austero e tímido de André, jamais se manifesta de outra maneira. Mas a carta endereçada anonimamente por Leonília a Teobaldo, com o intuito de destruir o casamento dele, acaba desencadeando uma cena de ciúme infundada, na qual o inocente André sai ferido. Na missiva, quando a loureira escreveu "seu melhor amigo" referia-se a Aguiar, contudo a maneira explosiva como Teobaldo reage ao encontrar Branca e André juntos nos faz supor que talvez aquele amor platônico que André nutria por Branca estivesse latente no imaginário de Teobaldo. Sentimento já notado por ele ao ver o amigo olhar para a esposa e que o levará a dizer em tom de troça: “Acha-as bonita, hein?”,228

Ainda que fisicamente André fosse um ser destituído de quaisquer encantos, há no romance outra personagem que se iguale a ele em virtude, dedicação e bondade, além de Branca?

Para fechar esses apontamentos sobre a formação dos protagonistas, não conseguimos deixar de estabelecer alguns pontos de contato dessa obra aluisiana com um exemplar dessa categoria: L'éducation sentimentale, de Flaubert.

\section{6. O Coruja e L'éducation sentimentale: uma aproximação}

Tanto como na obra aluisiana, o protagonista de L'éducation sentimentale, Frédéric Moreau, conhece Charles Deslauriers no colégio, e esse amigo o acompanhará até a última página do romance. Semelhante ao encontro entre Teobaldo e André, foi

\footnotetext{
${ }^{227}$ AZEVEDO, Aluísio. O Coruja. São Paulo: Livraria Martins Editora, 1963, p. 238-9.

${ }^{228}$ Idem, p. 239.
} 
um arrebatamento de cólera que fez nascer em Frédéric a admiração por Charles. Ao ser chamado de "joão-ninguém" por um funcionário do colégio, Deslauriers teria estrangulado o homem, não fosse a intervenção dos presentes.

Assim como André, Charles é pobre e as pessoas nutrem por ele uma surda antipatia durante sua permanência no colégio interno. Da mesma forma que fizera o tutor do Coruja, é deixado pelo pai no estabelecimento de ensino durante as primeiras férias. No ano seguinte, Frédéric passa para a série adiantada graças ao estímulo de Charles. Em contrapartida, Moreau convida-o para gozar férias na casa de sua mãe. A viúva não demonstra qualquer simpatia pelo amigo do filho, que come muito, não vai à igreja e tem ideias republicanas. Mas é graças às admoestações de Charles que Frédéric consegue terminar seu curso de Direito, e sempre lhe dizia: "Um diploma é sempre bom”. Frase bem parecida com a dita por André ao amigo Teobaldo.

Três anos mais velho, Charles parte primeiro para Paris com objetivo de cursar Direito. Ao término do curso, quer concorrer a uma cadeira de professor, mas por falta de recursos tem de voltar para a província e trabalhar como escrevente em um escritório de advocacia. Uma pequena herança, deixada pela mãe, lhe permite voltar para Paris, onde consegue doutorar-se, mas suas posições políticas impedem-no de conseguir uma cadeira e tem de se virar dando lições e escrevendo teses.

Finalmente, depois de alguns contratempos, Frédéric e Charles conseguem morar juntos por algum tempo em Paris. Até que a necessidade de ascensão social de Moreau afasta-o progressivamente do amigo de infância.

Contudo as semelhanças entre André e Charles terminam aqui. O amigo de Frédéric está longe de ter o caráter irrepreensível de André e tampouco a sua excessiva bondade. Deslauriers ambicionava riquezas, como meio de ter poder sobre os homens. E só não usufruiu o dinheiro que o amigo recebe de herança quando da morte de um tio, porque Frédéric, assim que põe a mão no pecúlio, esquece as promessas feitas na juventude: viajariam juntos pela Europa e depois voltariam para Paris, onde trabalhariam. E quando compra um palacete, desiste de convidar o amigo para morar com ele, pois sua presença poderia ser um tropeço para seu idílio amoroso com a Mme. Arnoux. Relação idealizada que de fato nunca se consumará. 
Os pontos de contato entre Frédéric e Teobaldo são bem maiores que no caso de André e Charles. Ambos são dotados de talentos que não se realizam. Moreau tenta ser romancista e pintor, mas não consegue se dedicar a nada com afinco. A duras penas termina seu curso de Direito e, como Teobaldo, é um grande perdulário. Frédéric também tem aspirações de chegar a ministro e não mede esforços nesse sentido.

Assim como o dinheiro herdado de Ernestina promove uma reviravolta na vida de Teobaldo, o mesmo se dá com Frédéric, ao receber a herança de um tio, pecúlio que logo é despendido em banalidades. A queda da bolsa é motivo para perda significativa de dinheiro por parte das duas personagens, e a busca por um bom casamento também passa a ser um caminho para Moreau, quando se vê desprovido de recursos. Decisão sempre adiada em função de seu amor idealizado por uma mulher casada e honesta, que não cede aos seus desejos, ainda que também esteja apaixonada.

Quanto à sua educação sentimental, também no caso de Frédéric quatro mulheres são fundamentais, como bem sintetiza Zola:

\begin{abstract}
Quatro mulheres trabalham para sua educação sentimental: uma mulher honesta e casada que ele vai justamente escolher para perder a seus pés as primeiras energias de sua vida; uma moça que não consegue contentá-lo, na alcova do qual deixa sua virilidade; uma grande dama, um sonho de vaidade, do qual desperta com desgosto e desprezo; uma provinciana, uma pequena selvagem precoce, a fantasia do livro, que um de seus amigos lhe tira quase dos braços. ${ }^{229}$
\end{abstract}

A despeito de tornar-se esposa de Teobaldo, coisa que Frédéric não conseguirá em relação a Mme. Arnoux, a retidão de caráter de Branca muito se assemelha a essa personagem de Flaubert. Assim como Leonília, Rosanete é uma cortesã, a quem Frédéric jamais se entregará de verdade, apesar de morar com ela por um tempo, ao sabê-la grávida de um filho dele. Louise pode ser associada a Joaninha, primeiro amor de Teobaldo, embora a personagem aluisiana se perca na infância, coisa que não acontece com Louise, que, em dado momento do romance, passa a ser um excelente partido, quando a viúva Moreau percebe o alto valor do dote da moça. Mas nenhuma dessas mulheres realmente conseguirá transformá-lo.

${ }^{229}$ ZOLA, Émile. Do romance. São Paulo: Edusp, 1995, p. 116. 
Assim sendo, como no caso de Teobaldo, as mulheres que passaram pela vida de Frédéric não conseguiram transformá-lo. Ainda que Teobaldo tenha fracassado porque, como ele mesmo dizia, "Definitivamente não nasci para sofrer pelas mulheres" 230 e a personagem de Flaubert tenha perdido tempo sofrendo demais por causa delas.

Sabemos que na França o Naturalismo foi fruto de uma nação desolada. É decorrente do fracasso da Revolução de 1848, da supressão da insurreição de junho e consequente tomada do poder por Luís Napoleão. Dolf Oehler faz importante estudo em que lê a L'éducation sentimentale ${ }^{231}$ sob a perspectiva do recalque provocado pelo massacre de junho de 1848 na França. Grosso modo, pode-se dizer que esse pesquisador vê essa obra de Flaubert como uma reflexão sobre a história prévia e posterior do fracasso da revolução de 1848: "uma reflexão sobre as condições econômicas, sociais e intelectuais que tornaram possível passar da euforia de fevereiro aos massacres de junho". 232

Nesse romance, Frédéric representaria a burguesia e há uma correspondência entre sua estrutura psíquica e das outras personagens do romance e o curso da história da época. Nesse caso, Frédéric assemelha-se à facção republicana burguesa de 1851 e a senhora Arnoux, à república idealizada e jamais alcançada. Assim: "o romance amoroso de Frédéric é compreendido em seu sentido político. [...] À maneira do culto que Frédéric vota à senhora Arnoux a adoração da (pequena-) burguesia pela república

\footnotetext{
${ }^{230}$ AZEVEDO, Aluísio. O Coruja. São Paulo: Livraria Martins Editora, 1963, p. 167.

${ }^{231}$ Lançado em 1869, L' éducation sentimentale abarca um período de 12 anos (1840-1852), em que se vê a agonia da monarquia, a instauração da República de fevereiro, o massacre de julho de 1848 e o golpe de 1951. Grosso modo, eis o que ocorreu neste período: paulatinamente, o governo de Luís Felipe perde o apoio da burguesia. A crescente urbanização e o consequente aumento da população operária e urbana-, impedida de se expressar politicamente, pois o voto continuava sendo censitário -, e a proliferação de ideias republicanas e socialistas, somada a uma grande crise econômica, favorece a eclosão de uma Revolução em 1848. No dia 24 de fevereiro, Luís Felipe abdicou. Um governo provisório proclamou a República. Sob esse governo, uma série de reformas políticas foram realizadas: estabelecimento do sufrágio universal masculino, abolição da escravidão nas colônias e da pena de morte para delitos políticos, redução da jornada de trabalho, dentre outras. Todavia, em abril realizaram-se eleições parlamentares, sendo eleita uma Assembleia Constituinte composta na sua maioria por liberais, pondo fim às conquistas socialistas conseguidas na primeira fase da Revolução. Em junho do mesmo ano, tem início uma série de revoltas contra a Constituinte. Os levantes foram reprimidos pela Guarda Móvel, mais de 10 mil civis foram executados sumariamente. Durante esse conturbado período, tiveram início as campanhas eleitorais para presidente. Saíram como candidatos o general Cavaignac e Luís Bonaparte, com vitória desse último. Durante seu governo, Bonaparte aliou-se aos setores da alta burguesia e organizou uma guarda particular. Em 1851, ele dá um golpe de Estado, que passou a ser conhecido na história como "o 18 Brumário de Luís Bonaparte". Logo após o golpe, Luís Bonaparte se faz coroar imperador da França, com o nome de Napoleão III. Tem início o segundo império, que vai durar até 1870.

${ }^{232}$ OEHLER, Dolf. Terrenos vulcânicos. São Paulo: Cosac Naify, 2004, p.18.
} 
compreende uma ambivalência fundamental, de modo tal que a reação está contida na revolução muito antes que esta última estoure". ${ }^{233}$

E no caso da obra aluisiana, qual terá sido a intenção do escritor brasileiro ao escrever esse romance que, a despeito de poder ser lido como um romance de formação, está longe do protótipo idealizado por Goethe? E que recursos estilísticos usou para urdir seu romance de formação? A essas questões procuraremos responder nos próximos capítulos.

${ }^{233}$ OEHLER, Dolf. Terrenos vulcânicos. São Paulo: Cosac Naify, 2004, p. 31. 


\section{CAPÍTULO 4 - FiguRAÇÕES dO GROTESCO NA COMPOSIÇÃO DO ROMANCE}

Neste capítulo, analisaremos a presença do grotesco na tessitura do romance $O$ Coruja. Entretanto, antes dessa análise propriamente dita, achamos por bem apresentar breve panorama sobre a evolução do grotesco enquanto categoria estética, com ênfase na forma como esse conceito foi tratado no Romantismo e no Naturalismo.

Para tanto, nos apoiaremos principalmente nos seguintes textos: Do grotesco e do sublime, de Victor Hugo, e $O$ grotesco, de Wolfgang Kayser. Outro estudo de relevância para avançarmos na discussão é a obra Cultura popular na Idade Média e no Renascimento no contexto de François Rabelais, de Mikhail Bakthin. Ainda que nela o estudioso retome vários aspectos tratados pelos autores supracitados, há uma ampliação necessária, sobretudo na maneira como são apresentados elementos sobre o uso do grotesco na estética naturalista. Dialogaremos também com a obra $O$ império do grotesco, de Muniz Sodré e Raquel Paiva, pois esses estudiosos trazem exemplos retirados da realidade brasileira.

\subsection{A evolução do grotesco como categoria estética}

O termo grotesco vem do italiano La grottesca e grottesco, que são derivações de grotta (gruta): "Palavras usadas para designar determinada espécie de ornamentação, encontrada em fins do século XV, no decurso de escavações feitas primeiro em Roma e depois em outras regiões da Itália. O que se descobriu foi uma espécie até então desconhecida de pintura ornamental antiga". ${ }^{234}$

No século XVII, o termo foi levado para outros países da Europa, conquistando diferentes áreas da ornamentação, do desenho à decoração de interiores, passando pela arte da imprensa e da joalheria. Nessa época, o grotesco passa a ser considerado um

${ }^{234}$ KAYSER, Wolfgang. O grotesco: configuração na pintura e na literatura. São Paulo: Perspectiva, 2003, p. 18. Obra originalmente publicada em 1957. 
estilo artístico ornamental e, em certa medida, está intimamente ligado ao Maneirismo.

Se, durante o Renascimento, a arte era fundamentada na imitação harmoniosa da natureza, no Maneirismo há uma ruptura com o modelo clássico vigente até então. A deformação das figuras é justificada por esse desejo intrínseco da recusa à imitação das regras, o que permite aos artistas experimentar também o rompimento com a perspectiva e o conceito de proporção.

A representação de imagens distorcidas e o deslocamento do tema central da composição começam a ganhar espaço nas obras de arte. Figuras de proporções alongadas, com expressão emocional acentuada pelo uso de cores contrastantes, podem ser encontradas em artistas adeptos desse estilo. Bons exemplos disso são os murais pintados para representar a Via Crucis, em Certosa di Val d'Ema, por Jacopo Pontorno (1499-1557).

Formas corporais alongadas e uso de cores incomuns também são frequentes nos temas claramente católicos pintados por El Greco (1541-1614). Todavia, o máximo dessa representação extravagante do disforme é encontrada nas pinturas de Arcimboldo (1530-1593), que concebia obras grotescas feitas de legumes, flores e frutas, organizados de forma a representar figuras humanas. Alguns quadros eram retratos satíricos, outros alegorias, como a famosa série das quatro estações, pintados sob o patrocínio de Maximiliano II, da corte de Hamburgo, Viena.

Paulatinamente, a apologia ao feio e ao disforme passa a ocupar espaço também na literatura. Na poesia barroca, é comum o elogio à mulher feia, vesga ou corcunda. Umberto Eco faz importante apontamento sobre a melancolia diante da velhice masculina, que grassa, por exemplo, em versos de Shakespeare.

Mas eu, que não fui moldado para jogos ou brincos amorosos, nem feito para cortejar um espelho enamorado; eu que rudemente sou o marcado, e que não tenho majestade do amor para pavonear-me diante de uma musa furtiva e viciosa; eu, que privado sou da harmoniosa proporção, erro de formação, obra da natureza enganadora, disforme, inacabado, lançado antes do tempo para este mundo que respira, quando muito meio feito, e de tal modo imperfeito e tão fora de estação que os cães ladram quando passo, 
coxeando perto deles. ${ }^{235}$

A referência frequente às partes baixas do corpo também começa a ser usada nas artes plásticas, como forma de representar a animalidade do homem, e posteriormente ganha espaço na literatura. Marco importante dessa estética, bem representada nas obras de arte, é a "reversibilidade entre o humano e o animal". 236

É ainda no século XVI que o substantivo começa a ser usado como adjetivo para designar algo desproporcional, monstruoso. Nesse período, o termo grotesco é dicionarizado em língua francesa, passando a figurar também como sinônimo de ridicule, de comique.

Durante o século XVII, a utilização de gravuras no estilo de caricatura para ilustrar obras como Dom Quixote e As viagens de Gulliver fez com que o grotesco fosse confundido com o conceito de caricatura. Usada como instrumento voltado para a configuração de uma pessoa real, ou de uma categoria social reconhecível, com o firme propósito de denúncia ou zombaria, a técnica consiste em exagerar na representação de traços corporais, até a deformidade. A partir de então, a arte enquanto reprodução da bela natureza passou a ser questionada, pois a caricatura fazia exatamente o contrário.

É importante lembrar da importância da charge e da caricatura na produção de artistas brasileiros do século XIX, inclusive de Aluísio Azevedo, como apresentado por nós no primeiro capítulo e ilustrado com anexos incluídos ao final deste estudo. Muniz Sodré e Raquel Paiva sintetizam bem a importância do humor crítico na vida política desse período:

Tanto a charge (entendida como reprodução realista de personagens) quanto a caricatura (desenho de natureza crítica ou paródica) ocupam, aliás, um lugar muito especial na história da inteligência escrita brasileira. Sempre foram um meio de comunicação de assuntos sérios, sem a sisudez da linguagem convencional. Durante a Monarquia, as charges críticas de Ângelo Agostini na Revista Ilustrada fizeram tanto pelas campanhas abolicionistas e republicanas

\footnotetext{
${ }^{235}$ Trecho de Ricardo III, de William Shakespeare, citado por Umberto Eco em: História da Feiura. Rio de Janeiro: Record, 2007, p. 177.

${ }^{236}$ MUNIZ, Sodré e PAIVA, Raquel. O império do grotesco. Rio de Janeiro: Mauad, 2002, p. 28.
} 
quanto os argumentos dos grandes intelectuais da época. ${ }^{237}$

Todavia, Wolfgang Kayser amplia o conceito aplicado por Wieland ${ }^{238}$ na caricatura ao associá-lo também ao drama e ao romance, pois acredita que "como fenômeno puro o grotesco se distingue claramente da caricatura chistosa ou da sátira tendenciosa, por mais amplas que sejam as transições e por fundadas que sejam as dúvidas em cada caso".239

Destaque também é dado à commedia dell'arte. A despeito de essa forma de arte dramática não ter sido significativa na Alemanha, Kayser considera relevante a importância do burlesco nessa estrutura textual, devido ao uso de adereços como as máscaras para destacar o animalesco nas formas humanas:

As máscaras, como é fácil compreender, servem de meio para aplicar aos corpos humanos algo de animalesco: surgem assim narizes enormes, embicados, aos quais corresponde um queixo pontiagudo, enquanto a cabeça desponta mais atrás ainda, alongada, e na maioria das vezes os traços ornitoides se complementam em excrescências com formas morcegais e agitados remígios de galo. ${ }^{240}$

\subsection{O grotesco romântico}

Foi no contexto do Romantismo, ${ }^{241}$ já no início do século XIX, que o grotesco

\footnotetext{
${ }^{237}$ KAYSER, Wolfgang. O grotesco: configuração na pintura e na literatura. São Paulo: Perspectiva, 2003, p. 68.

${ }^{238}$ Kayser cita Wieland, teórico da caricatura, que, em 1775, apresentou três definições para essa forma de representação: 1. "as caricaturas verdadeiras, onde o pintor simplesmente reproduz a natureza disforme tal como a encontra; 2. as exageradas, onde com algum propósito especial aumenta a deformação de seu objeto, mas procede de um modo tão análogo ao da natureza que o original continua sendo reconhecível; 3. as inteiramente fantásticas, onde o pintor, despreocupado com a verdade e a semelhança, se entrega a uma imaginação selvagem (como, por exemplo, o assim chamado Brueghel dos Infernos), e através do sobrenatural e do contrassenso dos seus produtos cerebrais, quer despertar com eles apenas gargalhadas, nojo e surpresa pela audácia de suas criações monstruosas." KAYSER, Wolfgang. O grotesco: configuração na pintura e na literatura. São Paulo: Perspectiva, 2003, p. 30.

239 KAYSER, Wolfgang. O grotesco: configuração na pintura e na literatura. São Paulo: Perspectiva, 2003, p. 30.

${ }^{240}$ Idem, p. 43.

${ }^{241}$ Otto Maria Carpeaux nos informa que o Romantismo foi a escola literária mais especificamente alemã. O movimento nasceu perto de Weimar, na cidade universitária de Iena. Tudo teria começado quando
} 
ganhou estatuto de categoria estética. Diante das contradições insuportáveis inerentes ao mundo real, os românticos buscavam certa unidade apenas encontrada no plano mítico, onírico e fantástico. Anatol Rosenfeld e Jacó Guinsburg bem nos lembram que, se de alguma maneira os românticos enfrentaram a realidade, isso se deu por meio do grotesco,

Mobilizando tudo o que na existência humana lhe causava aversão, o espetáculo do contraditório e absurdo, articulou estes elementos num retrato contundente quando não monstruoso, graças a um meio estilístico que se não era novo, não era muito explorado até então, já por seu caráter chocante e perturbador. De fato o grotesco, tão congenial à arte contemporânea, foi efetivamente promovido pelos românticos. ${ }^{242}$

Esses elementos do contraditório e do absurdo são bem apresentados em texto fundamental para a compreensão da importância do grotesco para a estética romântica: o prefácio para a peça Cromwell, escrito em 1827 por Victor Hugo.

Nesse texto, o escritor francês apresenta a evolução do texto dramático em corte diacrônico da era primitiva, ou fabulosa - em que a sociedade é representada pela comunidade pastoril e nômade -, até chegar à necessidade de criação do drama moderno. Após afirmar que no tempo dos patriarcas a prece é a religião e a ode é a poesia, ${ }^{243}$ Hugo debruça-se sobre os principais aspectos da tragédia grega, no intuito de demonstrar que, na Antiguidade, culto e história se misturam no teatro e a epopeia passa a ser o ponto de partida para toda a criação dramática:

É sobretudo na tragédia antiga que a epopeia sobe ao palco

Johann Gottlieb Fichte (1762-1814) escreveu uma série de discursos dirigidos contra Napoleão e os franceses. Mas foi com Goethe que o Romantismo ganhou força, com intensificação do sentimento nacionalista. A importância do termo "Weltliteratur", criado por ele, e que significa "literatura universal", fez com que se priorizasse a tradução para o alemão de grandes clássicos da literatura universal, como obras de Shakespeare, Dante, Camões e Cervantes. No entanto, não era só na região de Weimar que o espírito nacionalista romântico tomava forma. Em Heidelberg, um grupo de românticos, sob o comando de Joseph Goerres (1776-1848), se levanta contra a cultura estética de Weimar e, para combater o excesso de racionalismo daquele grupo, exalta não a literatura canônica, mas a de cunho popular. Cf: CARPEAUX, Otto Maria. A literatura alemã. São Paulo: Cultrix, 1964, p. 94-96.

${ }^{242}$ ROSENFELD, Anatol e GUINSBURG, Jacó. "Um encerramento". In: GUINSBURG, J. (Org.) $O$ romantismo. São Paulo: Perspectiva, 2002, p. 291.

${ }^{243}$ HUGO, Victor. Do sublime e do grotesco: tradução do prefácio de Cromwell. São Paulo: Perspectiva, 2007, p. 17. 
sem nada perder, de alguma forma, de suas proporções gigantescas e desmedidas. Suas personagens são ainda heróis, semideuses, deuses; suas molas, sonhos, oráculos, fatalidades; seus quadros, enumerações, funerais, combates. O que cantavam os rapsodos, declamam-nos os atores, eis tudo. ${ }^{244}$

Com o advento do Cristianismo, introduz-se no espírito dos povos um sentimento novo. Na sociedade antiga, o indivíduo era tão desconsiderado que só se sentia atingido se alguma adversidade caísse sobre toda a sua família. Mas, com o estabelecimento da sociedade cristã, os acontecimentos que abalaram toda a Europa, em prol da necessidade de expandir a fé cristã, fez com que o homem, voltado para si mesmo em presença destas profundas vicissitudes, começasse a sentir dó da humanidade e a meditar sobre as amargas irrisões da vida. Desse sentimento nasceu a melancolia. ${ }^{245}$

Em contrapartida, o Cristianismo conduz também à "poesia à verdade", ${ }^{246}$ revelando que nem tudo na criação é belo. É nesta altura do célebre prefácio, que Hugo apresenta a dicotomia que permeará, doravante, todo o texto: "o feio só existe ao lado do belo, o disforme perto do gracioso, o grotesco no reverso do sublime, o mal com o bem, a sombra com a luz". ${ }^{247}$ É justamente esse paradoxo que dará forma à comédia.

Chega finalmente à obra de Shakespeare, apontado-o como a sumidade poética dos tempos modernos, pois é a pena do escritor inglês "que funde o sublime e o grotesco, o terrível e o bufo, a tragédia e a comédia, o drama e o caráter próprio da terceira época de poesia da literatura atual". ${ }^{248} \mathrm{Na}$ tentativa de revelar que os conflitos encontrados no drama são inerentes a esse homem conflitado por oscilações violentas de temperamento, paixões e conflitos internos, "Victor Hugo frisa precisamente que o período romântico cria ou procura revelar a consciência do discorde no homem e no próprio universo; justamente o contrário do Classicismo, que se afaina em captar a

\footnotetext{
${ }^{244}$ HUGO, Victor. Do sublime e do grotesco: tradução do prefácio de Cromwell. São Paulo: Perspectiva, 2007, p. 19.

${ }^{245}$ Idem, p. 26.

${ }^{246}$ Ibidem.

${ }^{247}$ Ibidem.

${ }^{248}$ Idem, p. 40.
} 
harmonia universal". 249

Isso quer dizer que o gênio moderno teria nascido da fecunda união do tipo grotesco com o sublime, em que o caráter do drama resultaria justamente dessa combinação harmoniosa de dois modelos: o sublime e o grotesco, "que se cruzam no drama, como se cruzam na vida e na criação". ${ }^{250}$ O mérito de Hugo neste famoso prefácio, mais do que apresentar as bases de um gênero teatral novo, foi ter conseguido identificar a problemática da dualidade na estética romântica.

Essa dicotomia, que permeia todo o prefácio, se insere em uma longa tradição que é percorrida pelo escritor francês para dar ao grotesco uma base teórica, mas fundamentada na literatura e na organização social dos grupos humanos, ao longo do tempo. Nos exemplos apresentados por Hugo, o grotesco é visto como popular em oposição à estética dos privilegiados. Portanto, poderíamos concluir que o percurso feito por ele, e que passa a ser um marco no conceito de disgusto, tão caro aos românticos, é uma reação aos dogmas moralistas ditados pela hegemonia política burguesa de então.

Outro aspecto importante é que nesse texto ganha espaço a presença do disforme, do horroroso, do monstruoso, como manifestações do grotesco, mas tendo como contraponto o sublime:

O sublime sobre o sublime dificilmente produz um contraste, e tem-se necessidade de descansar de tudo, até do belo. Parece, ao contrário, que o grotesco é um tempo de parada, um termo de comparação, um ponto de partida, de onde nos elevamos para o belo com uma percepção mais fresca e mais excitada. ${ }^{251}$

Kayser defende que a conceituação do grotesco na literatura já havia sido abordada bem antes desse famoso texto de Victor Hugo. O termo fora tangenciado com a literatura pelos alemães Goethe, em artigo intitulado "Dos arabescos", publicado na revista Mercúrio Alemão, em 1789, e por Friedrich Schlegel, em 1800, no texto "Discursos sobre a poesia". Nessa obra, o grotesco e o arabesco já são usados como

${ }^{249}$ ROSENFELD, Anatol e GUINSBURG, Jacó. "Romantismo e Classicismo." In: GUINSBURG, J. (Org.) O romantismo. São Paulo: Perspectiva, 2002, p. 274.

${ }^{250}$ HUGO, Victor. Do sublime e do grotesco: tradução do prefácio de Cromwell. São Paulo: Perspectiva, 2007, p. 46.

${ }^{251}$ Idem, p. 33. 
elementos que podem provocar a destruição da ordem habitual do mundo. Reitera ainda que na obra Fragmentos, de Schlegel, já se pode encontrar inclusive certa distinção entre os termos caricatura e grotesco:

Grotesco é o contraste pronunciado entre forma e matéria (assunto), a mistura centrífuga do heterogêneo, a força explosiva do paradoxal, que são ridículos e horripilantes ao mesmo tempo. Como na estética do século XVII, os conceitos de caricatura, mas também os do trágico e do cômico, penetram nos enunciados: a caricatura é uma vinculação passiva do ingênuo e do grotesco. O poeta pode empregá-la tanto trágica, como comicamente. Dizendo de outra forma, resultaria que o grotesco é caricatura sem ingenuidade. ${ }^{252}$

Quanto à presença do grotesco na prosa, ainda é a partir de Kayser que damos continuidade às reflexões. O estudioso apresenta as três formas de grotesco presentes na obra de Hoffmann, o grande representante do macabro na prosa do século XIX alemã.

Há, primeiro, a figura extremamente grotesca (na imagem de sua aparência e nos movimentos) [...] O segundo tipo é constituído pelos artistas excêntricos. Na maior parte, também apresentam aparência bizarra, jogo facial exótico e selvagem, e movimentos excêntricos. [...] Em terceiro lugar temos as figuras demoníacas, de aspecto e conduta grotescos. ${ }^{253}$

Da obra de Raabe, retira elementos para discorrer sobre o fato de o grotesco paulatinamente transformar-se no bizarro, tendo como protagonista o indivíduo esquisito, original; ainda grotesco externamente, mas que nada tem de demoníaco. Estamos apenas diante de uma interioridade rica, que se protege sob uma máscara. ${ }^{254}$ Elementos que, como veremos mais adiante, são recorrentes na caracterização da personagem André.

A loucura é outro elemento importante, sobretudo porque tem função de "funil

\footnotetext{
${ }^{252}$ HUGO, Victor. Do sublime e do grotesco: tradução do prefácio de Cromwell. São Paulo: Perspectiva, 2007 , p. 57.

${ }^{253}$ KAYSER, Wolfgang. $O$ grotesco: configuração na pintura e na literatura. São Paulo: Perspectiva, 2003, p. 95

${ }^{254}$ Idem, p. 97.
} 
tragante", por meio do qual "um pequeno impulso basta para desencadear essa crescente turbulência que vai terminar no caos completo". 255

Não é exatamente isso que temos nas crises de histeria muito presentes em obras naturalistas? Tão bem exemplificadas nos ataques de Ernestina, na obra $O$ Coruja?

Outro elemento considerado por Kayser, e que também será relevante para nossa análise mais adiante, é a festa. Espaço especial em que as pessoas que dela participam têm abertura para o inesperado,

[...] pois ao seu feitio pertencem ao incomum, à magia da transformação e, para a pessoa participante, a abertura para algo operante. Esta soltura interior produz nos demônios, sempre à espreita, um estímulo, um convite direto para que irrompam em cena. $^{256}$

\subsection{O realismo grotesco}

Diferente do corte diacrônico utilizado por Kayser na análise do conceito de grotesco, ou da apresentação focada no drama, caso do prefácio de Victor Hugo, o caminho percorrido por Bakhtin é sincrônico, tendo como enfoque a obra de Rabelais.

Apesar de considerar a importância de seu antecessor alemão, segundo Bakhtin, Kayser ignora um aspecto fundamental do grotesco: a carnavalização. Daí a necessidade do pesquisador de recuar no tempo, indo buscar na Idade Média e no Renascimento os elementos necessários para seu estudo.

Essa dimensão carnavalesca do mundo - em certa medida responsável pela transformação do terrível em "luminoso" - não poderia ser encontrada na estética romântica, realista ou modernista, mas tão somente nas manifestações artísticas populares, em que o rebaixamento (bathos) manifesta-se, ou seja, nas produções

\footnotetext{
${ }^{255}$ KAYSER, Wolfgang. O grotesco: configuração na pintura e na literatura. São Paulo: Perspectiva, 2003, p. 102.

${ }^{256}$ Ibidem.
} 
medievais e renascentistas. Para Bakhtin:

Ao contrário do grotesco da Idade Média e do Renascimento, diretamente relacionado com a cultura popular e imbuído do seu caráter universal e público, o grotesco romântico é um grotesco de câmara, uma espécie de carnaval que o indivíduo representa na solidão, com a consciência aguda do seu isolamento. A sensação carnavalesca do mundo transpõe-se de alguma forma à linguagem do pensamento filosófico idealista e subjetivo, e deixa de ser sensação vivida (pode-se mesmo dizer corporalmente vivida) da unidade e do caráter inesgotável da existência que ela constituía no grotesco da Idade Média e do Renascimento. ${ }^{257}$

O estudioso russo chama de realismo grotesco a um sistema de imagens da cultura cômica predominante durante as manifestações artísticas populares da Idade Média, em que a carnavalização destacava-se. Nesse contexto, "o cósmico, o social e o corporal estão ligados indissoluvelmente numa totalidade viva e indivisível". ${ }^{258}$

Assim como feito por Kayser, Bakhtin retoma as posições de Victor Hugo sobre o grotesco. Mas, se para o primeiro a grande contribuição do escritor francês foi estabelecer um ponto de tensão entre o sublime e o grotesco, o segundo considera que essa contraposição justamente favoreceu o enfraquecimento dessa categoria estética. ${ }^{259}$

O estudioso estabelece interessante contraponto entre o grotesco na cultura popular medieval e na fase romântica. Enquanto no medievo imagens imprescindíveis à vida - como parir, comer e beber - eram usadas com o intuito de aproximar o homem do mundo "reintegrando-o por meio do corpo à vida", ${ }^{260}$ no grotesco romântico essas mesmas imagens eram usadas como expressão do temor, muitas vezes com o objetivo de assustar as pessoas.

O motivo da loucura, que permite a visão do mundo de um ponto de vista diferente, fora da ordem estabelecida pelo padrão de normalidade vigente em

\footnotetext{
${ }^{257}$ BAKHTIN, Mikhail. A cultura popular na Idade Nédia e no Renascimento: o contexto de François Rabelais. São Paulo: Hucitec, 2010, p. 33.

${ }^{258}$ Idem, p. 17.

${ }^{259}$ Idem, p. 38.

${ }^{260}$ Idem, p. 34.
} 
determinada sociedade, também tem peculiaridades nos dois casos. No grotesco popular, a loucura é festiva; já no contexto romântico, ela adquire tons sombrios. Como bem nos explica Mikhail Bakthin:

Outras peculiaridades do grotesco romântico denotam o enfraquecimento da força regeneradora do riso. O motivo da loucura, por exemplo, é característico de qualquer grotesco, uma vez que permite observar o mundo com um olhar diferente, não perturbado pelo ponto de vista "normal", ou seja, pelas ideias e juízos comuns. Mas, no grotesco popular, a loucura é uma alegre paródia do espírito oficial, da gravidade unilateral, da "verdade" oficial. É uma loucura festiva. No grotesco romântico, porém, a loucura adquire os tons sombrios e trágicos do isolamento do indivíduo. ${ }^{261}$

\subsection{O grotesco no Naturalismo}

Antes de adentrar na presença do grotesco no Naturalismo, é importante lembrar que na Alemanha e na França os dois termos têm sentidos distintos. Para os franceses, Naturalismo e Realismo são termos quase sinônimos, sendo que o Naturalismo está imbricado no Realismo.

Já na tradição alemã, distinguem-se bem os dois termos, havendo certa oposição entre eles. O Naturalismo na Alemanha designa um período curto, que vai de 1880 a 1910, sendo uma espécie de prólogo da literatura moderna. Portanto, quando o Naturalismo estava acabando na França, começava na Alemanha, uma vez que, para os franceses, essa estética durou de 1865 a 1880.

Segundo Yves Chevrel, ${ }^{262}$ a originalidade do Naturalismo francês deveu-se a três razões. Em 1881, Zola publica uma série de artigos sob o título Les romanciers naturalistes, em que, de certa forma, o Naturalismo é tratado como herança dos três principais romancistas do Realismo (Stendhal, Balzac e Flaubert). A segunda razão é a

${ }^{261}$ KAYSER, Wolfgang. O grotesco: configuração na pintura e na literatura. São Paulo: Perspectiva, 2003 , p. 35.

${ }^{262}$ CHEVREL, Yves. "Poétique du Naturalisme". In: BESSIÈRE, J. (Org.). Histoire des poétiques. Paris: PUF, 2000. 
tradição praticada pela historiografia francesa, que geralmente adota a divisão por séculos, ficando assim o Naturalismo no final do XIX e começo do XX, período marcado por expressiva produção editorial.

O terceiro motivo, preponderante da impulsão particular dada a essa escola na França, foi o empenho de Zola em integrar a nova estética e a sociedade, passando o homem de Letras a ter uma situação ambígua: “A poética do Naturalismo passa então a ter certa função política". ${ }^{263}$

De acordo com o próprio Zola, “A poesia, ou melhor, o produto poético, é uma mercadoria e, na atualidade, as leis da política de preços e transações comerciais se aplicam ao produto poético, caso do livro, como a outro qualquer". ${ }^{264}$ Yves associa essa frase do escritor francês à expressão "marche des biens symboliques", de Pierre Bourdieu, e reitera que a importância de uma independência financeira, adquirida a partir da escrita como prática profissional, é inseparável de certa organização na produção literária. Isso, em certa medida, contribuiu para que o escritor se tornasse mais livre dentro do sistema liberal, desvencilhando-se das ingerências das autoridades políticas e religiosas. Guardadas as devidas proporções, entre a realidade francesa e a brasileira no mesmo período, importante lembrar o empenho de Aluísio Azevedo em viver da própria pena, como demarcamos no primeiro capítulo deste estudo.

Chevrel observa também que, de maneira geral, o escritor naturalista tinha como meta reportar-se a duas noções básicas: análise e reprodução. Isso exigia observação minuciosa do objeto e do que o circundava. Por isso, a família é uma espécie de microssociedade nos romances naturalistas, e a entrada de uma personagem exterior ao grupo desencadeia uma série de acontecimentos, provocados pelo desconhecimento das regras que imperam em determinado ambiente. Essa chegada do elemento estranho àquela realidade faz explodir uma parte do acordo inicial estabelecido entre as personagens, dando origem aos conflitos. Um bom exemplo é o caso de Étienne, na obra Germinal, de Zola. ${ }^{265}$

${ }^{263}$ CHEVREL, Yves. "Poétique du Naturalisme". In: BESSIÈRE, J. (Org.). Histoire des poétiques. Paris: PUF, 2000, p. 350. Tradução nossa.

${ }^{264}$ Idem, p. 352. Tradução nossa.

265 Idem, p. 353. 
No geral, o escritor naturalista privilegia a função do observador, no instante em que decompõe e reconstitui a realidade, mas longe de simplesmente registrá-la, ele a reorganiza. Fato é que a poética do Naturalismo não começa no texto e tampouco termina nele. Isso porque o escritor naturalista, em grande medida, está preocupado em se debruçar sobre dada realidade social. Disso resulta que raros são os romances naturalistas que não se instalam em uma perspectiva histórica.

No caso brasileiro, o Naturalismo teve forte inspiração em escritores franceses e portugueses, como já apresentado nos dois primeiros capítulos e, apesar das divergências sobre o papel dessa filiação entre os diferentes críticos, há certa concordância em relação ao fato de que importantes eventos históricos ocorridos no último quartel do XIX encontraram ressonância na produção literária nacional. Dentre esses acontecimentos, podemos citar a Guerra do Paraguai (1870-1874); a promulgação da Lei do Ventre Livre (1871); a Questão Religiosa (1874); a implementação da Lei do Sexagenário (1885); a Abolição da Escravatura (1888) e a Proclamação da República (1889), dentre outros.

Essa inconformidade com a ordem vigente e a necessária mudança de paradigmas políticos, econômicos e sociais, em certa medida, favoreceu o acolhimento por significativa parte da intelectualidade das ideias positivista e do pensamento da então vanguarda alemã.

Portanto, se na França o Naturalismo derivou do fracasso da Revolução de 1848 e da consequente tomada de poder por Luís Napoleão, no caso brasileiro também não podem ser desconsideradas as grandes mudanças que abalavam os cenários político e social à época, exigindo um modelo estético diferente do romântico que grassava até então.

Todavia, não podem ser desconsideradas as diferenças entre os dois países nesse período. Enquanto o que se via na França era um quadro acelerado de transformações, com o capitalismo em franca expansão, acarretando extraordinário desenvolvimento urbano, com forte presença do proletariado nesses locais e a franca decadência da burguesia; em contrapartida, em nosso país, a acumulação capitalista ainda dava seus primeiros passos, com uma burguesia incipiente e predomínio da elite agrária. Como 
bem sintetiza Nelson Werneck Sodré:

A nova escola chegava ao Brasil, assim, numa fase de mudança, quando as velhas estruturas, profundamente ancoradas no passado colonial, sofriam forte abalo. [...] Pretender para o naturalismo, no Brasil, na mesma época do seu aparecimento na Europa, uma função específica, seria, pois, uma inversão do desenvolvimento histórico. Mas, apesar de tudo, apesar dessas contradições, apesar de ter sido transitório, o naturalismo, entre nós, apareceu e teve a difusão proporcional a tudo isso e mais às características naturais da sociedade brasileira, quanto à receptividade para a literatura, independente de escola. ${ }^{266}$

Ainda que seja significativa a diferença cronológica em relação à produção literária europeia, a questão principal, como bem pontua Sonia Brayner, é que no caso brasileiro [...] "o artista acha-se a braços com a tarefa difícil de construir uma literatura de ficção que traduza os anseios, as realidades e a estética de uma cultura em formação". ${ }^{267}$ A nosso ver, a questão que se coloca é ainda mais complexa: estamos diante não apenas de uma cultura em formação, mas de uma nação em formação. Tal aspecto nos leva a um labirinto de reflexões que tentaremos pelo menos tangenciar no capítulo seguinte. Por agora, continuaremos a confrontar algumas ideias a respeito do grotesco no Naturalismo.

Importante lembrar que Émile Zola baseou-se na tese de Claude Bernard, no livro Introdução à medicina experimental, para defender suas ideias sobre a fusão entre arte e ciência. A metáfora passa a ser embasada na vitalidade orgânica. Elementos caros à Biologia, como evolução, seleção, determinismo e hereditariedade merecem destaque durante o processo de criação literária, isso leva os escritores naturalistas a terem certa obsessão pelo corpo.

Como bem explica Zola no prefácio da segunda edição de Thérèse Raquin, no qual descreve a paixão violenta entre as personagens centrais do romance:

\footnotetext{
${ }^{266}$ SODRÉ, Nelson Werneck. Naturalismo no Brasil. Belo Horizonte: Oficina de Livros, 1992, p. 266.

${ }^{267}$ BRAYNER, Sonia. Labirinto do espaço romanesco. Rio de Janeiro: Civilização brasileira, 1979, p. 30.
} 
Que se leia o romance com cuidado e ver-se-á que cada capítulo constituí o estudo de um caso curioso de fisiologia. Numa palavra, não tive senão um desejo: considerando um homem vigoroso e uma mulher insaciada, procurar neles o animal, e mesmo ver unicamente o animal, lançá-los num drama violento, e observar escrupulosamente as sensações e os atos desses seres. Eu simplesmente fiz com dois seres vivos o trabalho que os cirurgiões fazem com cadáveres. ${ }^{268}$

Com isso, o escritor francês quer provar que o homem ocidental do século XIX é patológico. A função da arte naturalista, então, seria moralizar, mostrar as mazelas que destruíam a sociedade adoentada. Nesse sentido, se no Romantismo buscava-se a salvação do homem no retorno ao natural, os escritores naturalistas veem na ciência a possibilidade de salvaguardar a sociedade.

É justamente o fato de a literatura do último quartel do XIX ser tão pautada no cientificismo, que permite uma fecunda utilização do grotesco como categoria estética. Sobretudo no que diz respeito à presença do corpo grotesco e da animalização das personagens. Na própria obra de Aluísio Azevedo os exemplos são abundantes. Como é o caso dos seguintes exemplos, tirados da obra $O$ cortiço:

A primeira que se pôs a lavar foi a Leandra, por alcunha a "Machona", portuguesa feroz, berradora, pulsos cabeludos e grossos, ancas de animal do campo. [...]

Era um português de seus trinta e cinco a quarenta anos, alto, espadaúdo, barbas ásperas, cabelos pretos e maltratados, caindo-lhe sobre a testa, por baixo de um chapéu de feltro ordinário; pescoço de touro e cara de Hércules, na qual os olhos, todavia, humildes como os olhos de um boi de canga, exprimiam tranquila bondade. ${ }^{269}$

No seu estudo sobre a criação de Machado de Assis e Gregório de Matos, Maria Eurides Pitombeira de Freitas elege a obra Quincas Borba para tecer suas considerações sobre a presença do grotesco na obra machadiana. Aspectos como a ideia fixa dessa personagem na premissa do Humanitismo e seu progressivo enlouquecimento são

\footnotetext{
${ }^{268}$ ZOLA, Émile. Théresè Raquin. São Paulo: Estação Liberdade, 2001, p. 10.

${ }^{269}$ AZEVEDO, Aluísio. O cortiço. São Paulo: Livraria Martins Editora, 1959, p. 46 e 54.
} 
analisados com o propósito de demonstrar que o grotesco é uma das categorias organizadoras da obra.

Sodré e Paiva também exemplificam o uso do grotesco em outra obra machadiana, ao citar trecho que aborda ironicamente uma situação trágica: "como Memórias Póstumas de Brás Cubas, que começa assim: 'ao primeiro verme que roeu as frias carnes do meu cadáver dedico com saudosa lembrança estas memórias póstumas'. Grotesca é igualmente a descrição, nesse mesmo romance, da personagem Quincas Borba, em sua 'sobrecasaca mais larga do que pediam as carnes - ou, literalmente, os ossos da pessoa...",.270

\subsection{A imagem do corpo grotesco}

A associação entre Quasímodo, personagem da obra $O$ corcunda de Notre Dame, de Victor Hugo, e André já foi apontada por Alcides Maya, conforme vimos no segundo capítulo. ${ }^{271}$ Recapitulando o que esse crítico declara sobre André, temos: "é uma figura sombria, crispada comicamente a sofrimentos de tragédia interior, é um ser humilde, feio e miserável, quase Alceste, meio Quasímodo, triste como a dor, grande como um protesto atirado ao destino". ${ }^{272}$

Achamos relevante aprofundar essa questão, apenas mencionada pelo crítico, porque há elementos de grotesco nessa obra do escritor francês, sobretudo na configuração da personagem Quasímodo, que ficam mais evidentes quando comparadas à beleza de Esmeralda, aspectos também evidentes no díptico André/Teobaldo. Já nas primeiras aparições de André na obra $O$ Coruja, ele é apresentado como um menino

\footnotetext{
${ }^{270}$ MUNIZ, Sodré e PAIVA, Raquel. O império do grotesco. Rio de Janeiro: Mauad, 2002, p. 77.

271 Eugênio Gomes também sugere essa aproximação entre as personagens de Hugo e Aluísio: "Certamente, as concepções desproporcionadas, cujo mais popular espécime era o Corcunda de NotreDame, atuavam sobre o inconsciente do escritor maranhense, quando lhe acudiu engendrar, com o Coruja, uma grande criação autônoma, à maneira daquelas que formam a epopeia do infra-humano da repulsiva galeria do Rougon-Macquart." GOMES, Eugênio. Prefácio da obra Girândola de Amores, de Aluísio Azevedo. São Paulo: Livraria Martins Editora, 1960, p. XXI.

${ }^{272}$ MAYA, Alcides. Discurso proferido na sessão extraordinária de 21/06/ 1914, na Academia Brasileira de Letras. Disponível em: <www.academia.org.br/abl/media/Tomo\%20I\%20\%201897\%20a\%201919.pdf>. p. 669. Acesso em: jun. de 2012.
} 
feio e desprovido de graça:

Era pequeno, grosso, muito cabeçudo, braços e pernas curtas, mãos avermelhadas e polposas, tez morena e áspera, olhos sumidos de uma cor duvidosa e fusca, cabelo duro e tão abundante, que mais parecia um boné russo do que uma cabeleira. Em todo ele nada havia que não fosse vulgar. ${ }^{273}$

As descrições dessa personagem durante a infância são sempre pautadas pela fealdade excessiva e falta de graça, apontadas não apenas pelo narrador, mas presentes também na construção da sua autoimagem.

E André, assim considerado, via-se perfeitamente, tinha-se defronte dos olhos, como se estivesse em frente a um espelho. Lá estava ele com a sua disforme cabeça engolida pelos ombros, com seu turvo olhar de fera mal domesticada, com os sobrolhos carregados, a boca fechada a qualquer alegria, as mãos ásperas e curtas, os pés grandes, o todo reles, miserável, nulo! ${ }^{274}$

Essa consciência da falta de beleza e graça pode também ser observada no romance de Hugo. A primeira vez que Quasímodo ganha voz na narrativa é justamente quando se dirige à linda Esmeralda, a quem acabara de salvar da morte, para dizer: "Eu lhe inspiro medo. Sou bem feio, não? não olhe para mim; escute-me apenas. À noite, pode passear por toda a igreja. Mas não saia da igreja, de dia nem de noite. Estaria perdida". 275

Todavia, no romance francês, as atrofias de Quasímodo, como as pernas tortas, que fazem dele um claudicante, e a corcunda são congênitas. Conforme apresentado na primeira descrição que temos dele, aos quatro anos, pouco antes de ser adotado pelo padre Claude Frollo:

Era uma pequena massa bastante angulosa e bastante inquieta, aprisionada num saco de tela levando impresso o monograma de messire Guillaume Chartier, então bispo de Paris, com uma cabeça

\footnotetext{
${ }^{273}$ AZEVEDO, Aluísio. O Coruja. São Paulo: Livraria Martins Editora, 1963, p. 19.

${ }^{274}$ Idem, p. 72.

${ }^{275}$ HUGO, Victor. O corcunda de Notre Dame. São Paulo: Editora Três, 1973, p. 220.
} 
aparecendo. Essa cabeça era bastante disforme; só se via uma floresta de cabelos ruivos, um olho, boca e dentes. ${ }^{276}$

A caracterização só é concluída páginas depois, quando o padre abre o pacote, onde o pobre órfão era conduzido: "Quando tirou a criança do saco, achou-a bem disforme, realmente. $\mathrm{O}$ pobre diabinho tinha uma verruga acima do olho esquerdo, a cabeça metida nos ombros, a coluna vertebral arqueada, o esterno proeminente, as pernas tortas". 277

Há muitas aproximações possíveis entre André e Quasímodo: os dois meninos são órfãos, pobres e foram acolhidos por clérigos aos quatro anos. Além disso, despertavam a repulsa nas pessoas devido aos corpos desprovidos de graça e ao acabrunhamento excessivo. Todavia, no caso de André, a deformação corporal não é congênita e ocorre paulatinamente. ${ }^{278}$

O grande deflagrador dessa degradação corporal é o excesso de trabalho, ao qual se submete, como professor, revisor e autor de um interminável compêndio de História do Brasil. Portanto, se no romance do escritor francês o corpo grotesco é fruto do acaso, na obra de Aluísio Azevedo são as precárias condições de vida da personagem que transformam seu corpo. E se André fica coxo ao final do romance, isso acontece devido ao tiro dado pelo seu único amigo e não por uma disfunção congênita.

Representante de uma classe ainda incipiente no Brasil naquele momento - a dos homens pobres e livres com pretensões intelectuais -, André é revisor de jornais e professor de gramática, português, latim, francês, história e geografia, com uma rotina bastante desgastante:

Dava uma parte do dia aos discípulos e uma parte da noite ao serviço do jornal. Deitava-se impreterivelmente à uma hora e acordava às cinco da madrugada; não tinha vícios de espécie alguma; não comia senão ao almoço e ao jantar e nem sequer pensava em mulheres. ${ }^{279}$

\footnotetext{
${ }^{276}$ HUGO, Victor. O corcunda de Notre Dame. São Paulo: Editora Três, 1973, p. 115.

${ }^{277}$ Idem, p. 120.

${ }^{278}$ Não queremos dizer com isso que Quasímodo não fora vítima de uma sociedade cruel e supersticiosa, onde ele é uma espécie de bode expiatório, mas estamos aqui nos referindo apenas à corporalidade física.

${ }^{279}$ AZEVEDO, Aluísio. O Coruja. São Paulo: Livraria Martins Editora, 1963, p. 91.
} 
Essas funções são exercidas por ele com afinco e, apesar da baixa remuneração, consegue economizar algum dinheiro na esperança de comprar um colégio. Para isso, passa por muitas privações materiais. Usa o mesmo fato durante anos, os sapatos estão sempre rotos, alimenta-se mal, dorme pouco e seu corpo vai tornando-se ainda mais torto e desprovido de graça com o passar dos anos. Como bem mostra este trecho de diálogo entre dona Margarida e Inezinha:

- Acho-o agora tão não sei como!... o diabo do homem parece que fica mais feio de dia para dia!

- A mim, o que lhe acho, acrescentou a outra - é mais bodega do que nunca: já não se sabe de que cor é o paletó que ele traz no corpo, e o chapéu parece que está a se acabar aos nacos! $!^{280}[\ldots]$

O caso do Coruja ganhou imediata circulação entre os amigos e conhecidos das duas senhoras, que principiaram logo a ver no inofensivo professor um terrível monstro, tão feio de alma quanto de corpo. $^{281}$

Em várias situações, como as transcritas acima, dona Margarida e a filha empregam termos grotescos ao se referirem ao corpo desajeitado de André. De certa forma, o narrador quer mostrar a hipocrisia dessas duas mulheres que o tratam de maneira rude, a despeito de serem sustentadas por ele.

O anormal tanto pode ser divertido como desagradável, e a deformidade física de André, que aumenta à medida que ele vai se transformando em um "monstro de bondade", provoca não riso e divertimento, mas espanto e repulsa.

Isso significa que a ideia fixa de André em busca da bondade absoluta também se torna grotesca. Isso porque, ao investir-se de tanto empenho em ser bom, tornou-se um objeto, utilizado por todos na busca de atingir seus próprios interesses. Ele não percebe que se transforma paulatinamente em elemento a serviço de uma sociedade onde os valores são mensuráveis em proporções quantitativas e não qualitativas.

\footnotetext{
${ }^{280}$ AZEVEDO, Aluísio. O Coruja. São Paulo: Livraria Martins Editora, 1963, p. 264.

${ }^{281}$ Idem, p. 316.
} 
Mas é do ponto de vista do amigo Teobaldo, quando se reencontram pela última vez, que a caracterização corporal de André ganha tons ainda mais grotescos:

Coruja afastou-se para ir buscar café e o outro então o considerou melhor. O desgraçado estava muito mais acabado e mais feio: caíalhe agora todo o cabelo sobre os olhos, que se sumiam debaixo das pálpebras; a boca envergava-se para baixo em uma expressão constante de desgosto e ressentimento; as costas arqueavam-se-lhe cavernosamente, tornando-o mais encolhido, mais mesquinho, mais reles. $^{282}$

Tanto em Victor Hugo como em Aluísio Azevedo, o corpo grotesco é apresentado como uma variação do feio "deformado". Todavia, como vimos, se no contexto romântico a deformação corporal era obra da natureza, no enredo naturalista ela é resultante das precárias condições de trabalho e da violência. Ainda que o tiro desferido contra André tenha sido dado em momento de fúria, acidente do qual Teobaldo se arrepende, ele torna o corpo do Coruja ainda mais grotesco.

Não obstante, o conceito de grotesco/sublime, que está presente no díptico Esmeralda/Quasímodo, também aparece na composição de Teobaldo/André. Daí a aproximação, tangenciada por Alcides Maya apenas na caracterização física das personagens centrais, ser passível de análise mais profunda, conforme veremos no próximo capítulo.

Por ora, vamos nos ater ao tema do corpo grotesco, que além de poder ser notado na caracterização de André, como apresentado acima, também se faz presente na criação de outras personagens do romance. Como pode ser visto a seguir:

Chacoteava a respeito do Coruja, apresentando sua boca de roedor as duas presas isoladas. (Descrição de Picuinha )

Não parecia mulher de trinta e cinco anos, mas de cinquenta. Faltavam-lhe dentes; o cabelo the encanecera e a pele do rosto lhe estalara em rugas; as mamas, repuxadas, caíam lhe até a cinta e os braços pareciam, quando se fechavam, espetar com a ponta do

${ }^{282}$ AZEVEDO, Aluísio. O Coruja. São Paulo: Livraria Martins Editora, 1963, p. 358. 
cotovelo aquilo que encontrasse. (Descrição de Inezinha)

Notou que o nariz do homem não era grego, nem árabe, nem tampouco romano e que, se o separassem do rosto, ninguém seria capaz de dizer o que aquilo era, e tanto podiam supor que seria um legume ensopado, como um pólipo extraído de um mexilhão fora da casca. (Descrição do sr. Almeida) ${ }^{283}$

A maneira como o narrador descreve o nariz do sr. Almeida produz efeitos satíricos, pois o exagero da caracterização é uma verdadeira caricatura. Tanto nesse caso como na apresentação grotesca das demais personagens podemos encontrar referências explícitas à seguinte afirmação de Bakhtin:

Coloca-se ênfase nas partes do corpo em que se abre ao mundo exterior, isto é, onde o mundo penetra nele ou dele sai ou ele mesmo sai para o mundo, através de orifícios, protuberâncias, ramificações e excrescências, tais como boca aberta, os órgãos genitais, seios, falo, barriga e nariz. ${ }^{284}$

A decrepitude corporal de Leonília, quando do seu reencontro com Teobaldo, também é descrita de maneira bastante grotesca: "Uma velhusca, muito gorda, o rosto coberto de rugas mal disfarçadas pelo alvaiade, os olhos cansados, os olhos descaídos, os dentes sem brilho, o cabelo reles, o hálito mau. Que diferença!"285

Distinto da tradição literária romântica, onde as mulheres fatais eram redimidas pelo grande amor, Leonília não foi amada por Teobaldo, desafiando a idealização romântica. Ao cabo do romance, ela envelhece sem redenção.

\subsection{O animalesco na configuração das personagens}

Para confirmar a hipótese de que Aluísio Azevedo recorre a comparações e metáforas em que a animalização das personagens tem configuração grotesca, podemos começar pelo título do romance, O Coruja. Animal situado dentre os noturnos e

\footnotetext{
${ }^{283}$ AZEVEDO, Aluísio. O Coruja. São Paulo: Livraria Martins Editora, 1963, p. 101, 301, 327.

${ }^{284}$ BAKHTIN, Mikhail. A cultura popular na Idade Média e no Renascimento: o contexto de François Rabelais. São Paulo: Hucitec, 2010, p. 23.

${ }^{285}$ AZEVEDO, Aluísio. O Coruja. São Paulo: Livraria Martins Editora, 1963, p. 351.
} 
rastejantes, a coruja é considerada grotesca porque está entre aqueles que "vivem em ordens diferentes, inacessíveis ao homem". ${ }^{286}$

Recapitulando a reflexão feita no capítulo anterior, o título já aponta para essa possibilidade de leitura da obra como um romance de formação às avessas, pois, em $O$ Coruja o escritor lança mão de um apelido. Procedimento diferente do adotado em várias narrativas dessa categoria, que são tituladas pelo nome do protagonista (David Copperfield, Jean Christophe, Os anos de aprendizagem de Wilhelm Meister, Sidarta, dentre outras).

A coruja é considerada tanto animal de mau agouro como símbolo de sabedoria, todavia, no contexto em que o apelido foi dado a André - por um colega no colégio interno com intuito de diminuí-lo perante o grupo -, refere-se apenas ao aspecto feio e taciturno da ave.

No entanto, a animalização de André é apontada pelo narrador bem antes disso, já na primeira página do romance. "O pequeno do padre", como era chamado por todos da comunidade onde viveu, antes de ir para o colégio interno, "era a criança menos comunicativa e mais embesourada de que havia notícia por aquelas alturas". ${ }^{287}$

Nota-se a presença da palavra besouro na raiz do adjetivo, usada pelo narrador com sentido de casmurro, mal-humorado. Esse inseto tem um par de asas anterior bastante rígido, que o protege como um estojo. Além disso, seu exoesqueleto é composto por numerosas camadas de placas de quitina, que também possibilitam uma espécie de defesa blindada. Daí possivelmente a adjetivação da palavra com sentido de ensimesmado.

A comparação de André com o macaco também aparece com frequência na obra. Por exemplo, na descrição feita quando ele ainda vivia na casa do padre Estevão temos: "Deixava-se o mono ficar no lugar em que o largavam". 288

Teobaldo compara o amigo a um símio ao notar sua inépcia na montaria. As palavras que usa para repreender André durante as aulas que dá ao amigo denotam isso:

\footnotetext{
${ }^{286}$ KAYSER, Wolfgang. O grotesco, configuração na pintura e na literatura. São Paulo: Perspectiva, 2003, p. 157.

${ }^{287}$ AZEVEDO, Aluísio. O Coruja. São Paulo: Livraria Martins Editora, 1963, p.15.

${ }^{288}$ Idem, p. 16.
} 
“- Espicha as pernas, rapaz! Levanta a cabeça! Pareces um macaco!”289

Também é essa analogia que faz o alfaiate durante a prova do terno costurado para André, a mando do pai de Teobaldo: “- Não podia acreditar que houvesse alguém com as pernas tão curtas e os braços tão compridos. Parece um macaco". 290

Portanto, usa-se a comparação com o macaco para referir-se às características físicas do garoto. A aparência corporal desajeitada dele advém justamente da desproporção de tamanho entre os membros posteriores e inferiores, evidente nos símios. O símio, como nos lembra Rosenfeld, "é um motivo grotesco antigo". ${ }^{291}$

Quanto à sua inabilidade para o convívio social, o próprio André se associa a um asno, quando lamenta não ter a mesma presença de espírito e elegância do amigo. ${ }^{292}$ Algumas páginas depois, nesse mesmo capítulo, é sob uma "crosta de elefante," 293 que tenta dissimular-se diante dos pedidos de Branca, desejosa de ler seus escritos.

Na presença dessa bela senhora, André fica tão acanhado e se sente tão estúpido que "não encontrava posição defronte daquele primor de beleza, e conseguia apenas uivar algumas vozes confusas e quase sem nexo". ${ }^{294}$

Compara-se o apetite alimentar de André, durante o período em que vive na casa do padre e no colégio interno, à "voracidade canina". ${ }^{295}$ E sente-se um cão leproso nas festas suntuosas dadas pelo amigo, que se tornara um político famoso. ${ }^{296} \mathrm{O}$ cão é associado à fidelidade em diferentes culturas. Essa lealdade canina, ligada a uma doença degenerativa, considerada repugnante à época em que o livro foi escrito, mostra bem o estado d'alma do pobre André. Ele sabia ser sua presença penosa ao amigo, mas, ao mesmo tempo, como um cão fiel, não conseguia afastar-se dele.

Em algumas tradições xamanistas indígenas da América do Sul, América Central e Sibéria, o cão chega a ser enterrado com seu dono, para ajudá-lo na passagem de um

\footnotetext{
${ }^{289}$ AZEVEDO, Aluísio. O Coruja. São Paulo: Livraria Martins Editora, 1963, p. 56.

${ }^{290}$ Idem, p. 68.

${ }^{291}$ ROSENFELD, Anatol. “A visão grotesca.” In: Texto e contexto. São Paulo: Perspectiva, 2006, p. 63.

${ }^{292}$ AZEVEDO, Aluísio. O Coruja. São Paulo: Livraria Martins Editora, 1963, p. 240.

293 Idem, p. 245.

${ }^{294}$ Idem, p. 239.

295 Idem, p. 23.

${ }^{296}$ Idem, p. 320.
} 
plano para outro, ${ }^{297}$ ritual por certo inspirado na aparente fidelidade dos caninos. Logo, não é por acaso que a última associação de André a um animal, trata-se justamente do cão. Durante o funeral de Teobaldo, o Coruja "acompanhou o enterro de longe, a pé, coxeando como um cão ferido que segue a carruagem do dono". ${ }^{298}$

Se, em casa de Teobaldo, André era comparado a um cachorro leproso, quando resolve mudar-se para um quartinho na casa de dona Margarida, para ajudar nas despesas da casa, é associado a um corvo:

E quem o visse tão maltrapilho, tão miserável, a bater a cidade de um ponto a outro à procura de fazer dinheiro; quem o visse tão reles, tão ordinário e tão chato, não seria capaz de acreditar que à sombra das asas daquele corvo se abrigava inteira uma família de pardais. ${ }^{299}$

A escolha do corvo pelo escritor também não foi gratuita. Visto que se trata de um animal bastante presente nas obras românticas, símbolo do isolamento voluntário. Tanto na China como no Japão, essa ave simboliza a gratidão filial, pois esse pássaro monogâmico costuma alimentar os pais na velhice. ${ }^{300}$

Portanto, a bondade de André para com a família de dona Margarida tanto pode referir-se ao aspecto grotesco e solitário da personagem, como à sua generosidade em alimentar uma família de pardais. Aves encontradas com facilidade tanto em áreas rurais como nos centros urbanos.

A utilização do corvo para representar André, ave considerada bastante inteligente, capaz inclusive de usar gravetos como ferramentas para abrir frutos mais duros, e de pardais - aves desprovidas da mesma habilidade, que proliferam com facilidade nos grandes centros -, associadas à família de dona Margarida, também pode ser vista como uma analogia à situação das classes sociais menos favorecidas economicamente no último quartel do século XIX. André, apesar de órfão e sem recursos financeiros, consegue ganhar a vida graças ao seu trabalho como professor e

297 Cf. CHEVALIER, Jean e GHEERBRANT, Alain. Dicionário de símbolos. Rio de Janeiro: José Olympio, 1982, p. 176-177.

${ }^{298}$ AZEVEDO, Aluísio. O Coruja. São Paulo: Livraria Martins Editora, 1963, p.15.

299 Idem, p. 329.

300 Cf. CHEVAlIER, Jean e GHEERBRANT, Alain. Dicionário de símbolos. Rio de Janeiro: José Olympio, 1982, p. 294. 
revisor e, com seus proventos, minimiza a miséria em que vive a família de dona Margarida. Com o ofício de lavadeira, essa senhora teria ainda menor possibilidade de conseguir sustento para si e Inezinha, acompanhada de sua prole.

Algumas páginas adiante, o narrador apresenta um André consciente de que se os membros da família de dona Margarida não precisassem dele para sustentá-los, seria enxotado como um cão impertinente. ${ }^{301}$ De novo a imagem positiva do cão, pautada na ideia de fidelidade, aparece associada a um termo negativo.

Mesmo quando se trata de uma aproximação afetiva, frequentemente André é vinculado a um animal. Teobaldo nessas ocasiões costuma tratá-lo por urso. Mesma analogia empregada por Inezinha ao vê-lo aproximar-se dela: “A resignada Inês, posto não desse demonstrações, tinha certo vexame quando via surgir no canto da rua, com a grande cabeça enterrada nos ombros, a jogar o corpo no seu pesado andar de urso". ${ }^{302}$

Além disso, André é a personagem que recebe o maior número de associação a animais (coruja, besouro, macaco, urso, cão, asno, elefante, corvo). Alguns animais usados em sua caracterização, caso do corvo e da coruja, tanto podem ser relacionados a aspectos sombrios e grotescos como à inteligência e sabedoria.

Esse aspecto revela-se também no caso do besouro. Apesar da couraça negra que o protege, conferindo-lhe aspecto grotescamente sombrio, o escaravelho simboliza a ressurreição. Na tradição egípcia, supõe-se que ele renasça da própria decomposição.

O cão, considerado símbolo da fidelidade, também recebe adjetivação negativa, como impertinente e leproso, tornando grotesca uma animalização inicialmente positiva. Às vezes, André é comparado a animais noturnos do rol do grotesco; em outras ocasiões, a mamíferos de grande porte, caso do urso e do elefante. Portanto, há um equilíbrio na configuração animalizada dessa personagem.

Todavia, quando se trata da representação de personagens secundárias do romance, sobretudo as representantes das classes menos favorecidas, impera a animalização grotesca. Dr. Mosquito é "mais ligeiro que um rato"; "D. Margarida era pequena, viva e seca como um camundongo"; Inezinha tinha ar de mosca morta; sr.

\footnotetext{
${ }^{301}$ AZEVEDO, Aluísio. O Coruja. São Paulo: Livraria Martins Editora, 1963, p. 336.

${ }^{302}$ Idem, p.302.
} 
Almeida se assemelhava a uma foca; Ernestina tinha "faro de cão matreiro". ${ }^{303}$

Na caracterização de Picuinha, alferes que acaba se casando com a pretendida de André, a animalização ganha maior potência. O narrador assim o descreve:

Tinha o nariz comprido, laminoso e de papagaio, os olhos fundos, o queixo muito metido para dentro, com uma boquinha de coelho. Quando soltava uma das suas escandalosas gargalhadas, viam-se-lhe as presas, solitárias, como as presas de um cão, porque ele já não possuía os dentes da frente.

O que mais chamou nossa atenção durante as leituras, para levantamento de exemplos significativos, foi o fato de personagens pertencentes à aristocracia rural e à burguesia comercial em formação raramente serem animalizadas ou, quando isso ocorre, a animalização ser feita de maneira menos grotesca.

Constatamos que o emprego da metáfora animalesca ocorre apenas duas vezes para caracterizar Teobaldo. A primeira na abertura do terceiro capítulo. Apresentam-se as mudanças na casa de Branca, depois do seu casamento com Teobaldo, para, em seguida, questionar-se o fato de o casal viver como se fossem milionários, quando o legado deixado pelo pai da noiva era pouco significativo. Com as seguintes advertências esse narrador intruso animaliza a personagem: “Ora queira Deus, Teobaldo! Que não tenhas feito entrada de leão, sem saber ainda com a saída de que bicho hajam de comparar a tua retirada!..."304

Ao final desse trecho - em que o leitor se pergunta como o narrador pode ter tom tão especulativo - vem a frase: "Isto dizia a boca do mundo, todas as vezes que ele mais a mulher atravessavam a praia de Botafogo ou as ruas da cidade, no seu magnífico landau, tirado por duas éguas de raça". ${ }^{305}$ Ou seja, o narrador coloca na "boca do povo" esse julgamento do comportamento perdulário de Teobaldo.

Na segunda vez que Teobaldo é animalizado, o referente é ao mesmo felino. Comparação que combina com o porte de homem elegante, imponente e vaidoso. Com

\footnotetext{
303 AZEVEDO, Aluísio. O Coruja. São Paulo: Livraria Martins Editora, 1963, p. 41, 92, 93, 101, 165.

${ }^{304}$ Idem, p. 231.

305 Ibidem.
} 
olhar de leão cioso ele vê André recebendo um beijo de agradecimento de Branca e, tomado de fúria, atira no amigo sem pestanejar.

Branca também é animalizada, mas nunca de maneira grotesca. Quando Teobaldo afasta-se da esposa, pois só tem em vista sua ascensão social e política, compara-se a jovem a uma ave: "No seu olhar de rola abandonada pelo esposo, não transparecia o mais leve indício da tremenda revolta que mantinha sua alma contra aquela sociedade de mentirosos em que ela vivia". ${ }^{306}$ Importante lembrar que a rola simboliza a fidelidade conjugal na tradição cristã.

Com a ligeireza de um pássaro, Branca desvencilha-se dos assédios do primo, antes de esbofeteá-lo e correr dele como uma "corça que pressente a próxima tempestade" ${ }^{307}$ Portanto, frequentemente associa-se a esposa de Teobaldo a aves.

Aguiar, comerciante bem-sucedido, representante da burguesia comercial ascendente, é comparado a uma fera enjaulada, por não ser correspondido no amor que sente por Branca. ${ }^{308}$ Note-se que a palavra águia, ave de rapina que devora pequenos pássaros, está imbricada no nome Aguiar.

Sabemos que a representação de pessoas dos grupos menos favorecidos da sociedade começa a ganhar mais espaço na literatura justamente com o Naturalismo, mas será que podemos dizer que, no imaginário de Aluísio Azevedo, essa identificação só se tornaria possível se revestida pelo grotesco ou pelo caricato? Ou seja, os tipos resultantes da história de miséria de um país monarquista e escravocrata apresentam uma essência figurativa de difícil classificação, que só pode ganhar espaço na representação simbólica literária se for por meio do corpo grotesco, da representação caricata ou da animalização?

Muniz Sodré e Raquel Paiva denominam essa classificação de "Imagem teratológica do povo". ${ }^{309}$ Teratológico (do grego teratos $=$ monstro + logos $=$ estudo). Esse termo é recorrente na área da ciência médica, para designar a interferência

\footnotetext{
${ }^{306}$ AZEVEDO, Aluísio. O Coruja. São Paulo: Livraria Martins Editora, 1963, p. 304.

${ }^{307}$ Idem, p. 230.

${ }^{308}$ Idem, p. 284.

${ }^{309}$ MUNIZ, Sodré e PAIVA, Raquel. O império do grotesco. Rio de Janeiro: Mauad, 2002, p. 128.
} 
ambiental no desenvolvimento fetal. Define-se um agente teratológico como qualquer organismo ou substância que possa interferir no crescimento saudável do feto.

Os estudiosos da comunicação usam o termo para analisar o fenômeno televisivo, em que pessoas das classes menos favorecidas são representadas de forma grotesca na arena dos auditórios como garantia de audiência. Todavia, podemos usar a terminologia "imagem teratológica do povo", para tentar compreender o uso do grotesco na representação de indivíduos das classes menos favorecidas economicamente no romance $O$ Coruja. Aluísio Azevedo não só insere indivíduos dessas classes em seu romance, como faz de André um dos protagonistas da obra, ainda que essa representação seja feita de maneira grotesca. Uma personagem moldada na caricatura, na animalização e na deformação corporal progressiva.

\subsection{A festa grotesca}

No romance de Aluísio Azevedo, há várias situações festivas que podem ser analisadas em uma perspectiva grotesca. Escolhemos três: a festa de casamento de dona Geminiana, tia de Teobaldo; uma homenagem feita a Teobaldo quando nomeado ministro; e um almoço promovido por ele na casa de dona Margarida. Apesar de esse último evento não se tratar de uma festa, na acepção imediata da palavra, apresenta muitos elementos do grotesco festivo, conforme se verá posteriormente.

Se considerarmos a festa como a representação simbólica identitária de um grupo, durante ela pode ocorrer uma subversão da ordem ou uma certa tensão entre as diferentes maneiras de se apropriar dos recursos culturais. Foi justamente na festa de casamento de dona Geminiana que André, tendo consciência dos dotes de Teobaldo, percebeu o quanto sua presença destoava do restante do grupo:

Nessa festa foi que o Coruja teve ocasião de apreciar mais largamente as brilhantes qualidades do amigo. Viu-o e admirou-o ao lado das damas, cortês e cavalheiro como um homem. [...] viu-o nas salas de dança, conduzindo uma senhora ao passo da mazurca, teso, correto, 
elegante mais do que nunca, e como possuído de orgulho pelo gentil tesouro que levava nos braços; viu-o à mesa erguer-se de taça em punho e fazer um brinde à noiva, levantando aplausos de toda gente, e o Coruja, de cujas mãos saíra aliás essa festejada peça literária, chegou a desconhecer a sua obra, tal o realce que lhe emprestavam os dotes oratórios do amigo. [...]

Ainda se Teobaldo, possuindo muitos dotes fosse miserável ou estúpido - vá! Mas não! Teobaldo era lindo, era rico, era talentoso e, além de tudo - amado. ${ }^{310}$

No entanto, o sentimento de inadequação sentido por André começa a desassossegá-lo um mês antes, quando os preparativos têm início: “O Coruja ia pela primeira vez em sua vida assistir a um baile, e essa ideia, longe de o alegrar, trazia-lhe um fundo de ressabio, de amargura, como se o desgraçado estivesse à espera de uma terrível provação".311

Toda a descrição da festa é marcada por excessos. Mais de 500 convidados comeram e beberam por vários dias. Uma tenda foi levantada no vasto terreiro da fazenda para abrigar os hóspedes, jatos de água eram iluminados por luzes de lanternas chinesas. Essa festa promovida pelo barão de Palmar chega a ser descrita como rabeliana. Emílio "queria o grosso prazer pantagruélico: - carne para mil! - vinho pra outros tantos!"312

Muito embora tudo não passasse de uma fartura aparente, ao final do capítulo o narrador já nos deixa antever que o barão de Palmar está à beira da falência. A festa foi, na verdade, uma forma de mascarar a derrocada econômica já iniciada e que será declarada ao final da segunda parte do romance.

Essa encenação da fartura diante da falência iminente está bem de acordo com os princípios do barão de Palmar, no que concerne à essência e à aparência, como deixa claro em carta enviada ao filho notificando o fato: "Nada de envolver estranhos neste negócio; mais vale arruinado em segredo do que às claras, porque tudo perdoam à gente,

\footnotetext{
${ }^{310}$ AZEVEDO, Aluísio. O Coruja. São Paulo: Livraria Martins Editora, 1963, p. 70.

${ }^{311}$ Idem, p. 69.

312 Ibidem.
} 
menos a pobreza".313

A segunda situação festiva que escolhemos para análise acontece no dia da nomeação de Teobaldo como ministro. A rua onde mora está repleta de pessoas que foram saudá-lo. As especulações a respeito de suas qualidades, bem como maneira com ascendeu rapidamente ao cargo, são discutidas pelos cidadãos comuns (a opinião pública), e presenciadas por André, que também vai saudar o amigo.

Estamos diante de uma festa popular e nenhum dos participantes é descrito. Por intermédio de André - que escuta as opiniões ora positivas, ora negativas ditas de um lado e do outro -, o leitor acompanha as especulações. Tudo isso ao som de uma banda, que toca o Hino Nacional.

A casa está repleta de gente. André aproxima-se e acompanha os festejos de longe. Pelo tilintar da alegria bem educada das vozes dos homens e das gargalhadas das senhoras, "imagina-se logo uma boa mesa servida com porcelanas e cristais de primeira ordem; imagina-se a confortável mobília, as largas cadeiras estofadas, a voluptuosa cama de molas de aço, o banho perfumado, as roupas de linho puro". 314

Como no casamento de dona Geminiana, André sente-se deslocado, mas na infância ele era um espectador direto das habilidades do amigo. Fora convidado para a festa e até ganhara um terno novo para usar durante o evento comemorativo. Na festa popular de agora, ele só vê Teobaldo de longe, quando este acena para o povo pela janela, mais parecendo um príncipe. Tudo o que André sabe sobre o amigo é colhido da boca de anônimos que foram cumprimentar o novo ministro.

Ao abrirem-se as portas da casa, as salas são invadidas pelo povo ao som da banda que continua a tocar. André, que fora barrado por um ordenança, volta para casa sem falar com o amigo: "E foi com a garganta cerrada por um punho de ferro que o mísero desceu lentamente a escada, arrastando de degrau em degrau o seu pé aleijado pelo tiro". ${ }^{315}$

A festa avança de maneira caótica. Um cenário aristocrata, sendo invadido pela

\footnotetext{
${ }^{313}$ AZEVEDO, Aluísio. O Coruja. São Paulo: Livraria Martins Editora, 1963, p. 106.

${ }^{314}$ Idem, p. 334.

${ }^{315}$ Ibidem.
} 
plebe ansiosa por saudar o novo ministro, enquanto um homem maltrapilho desce as escadas de pedra branca que dão acesso à chácara. Como bem afirma Kayser: "A festa 'grotesca', que finda em total estranhamento e dissolução no caos, é um motivo que retorna continuamente na história do grotesco e se justapõe ao da cidade, que se vai alienando e dissolvendo". 316

A terceira manifestação festiva escolhida como exemplo é um almoço promovido por Teobaldo na casa de dona Margarida. A cena ocorre dois meses depois de ele dizer ao amigo que preferia não recebê-lo em casa, na presença de outras pessoas.

Certa manhã de domingo, André é surpreendido pela visita de Teobaldo. À sua chegada já fica evidente o contraste entre a miséria reinante e sua figura aristocrática. A dona da casa está doente e acamada; enquanto André corre para atender o amigo, Inezinha foge para junto da mãe, "sobressaltada por aquela voz argentina e cheia de vida, que espantava a miserável tristeza da casa com a sua risonha expressão de estroinice fidalga". 317

Teobaldo vai ao quintal e olha para um tanque cheio de roupa suja, o leitor sabe que isso se deve ao fato de dona Margarida estar acamada, mas ele exclama: "- Como tudo isto é bom e consolador!" ${ }^{318} \mathrm{O}$ grotesco da situação salta aos olhos.

Algum tempo depois, chegam os pacotes de comida encomendados por Teobaldo para o fausto almoço: bolinhos de bacalhau, costeletas de porco, maionese de camarões, peixe recheado, pato assado. Tudo isso servido por Inezinha naquela casa de cômodos, sob o comando de voz de dona Margarida do seu leito de enferma. Depois de mandar servir um cálice de vinho à velha, Teobaldo vai ao quarto e deposita uma nota de dinheiro para cera dos santos ao pé do velho oratório.

Nos três casos aqui apresentados, ocorridos em momentos distintos do romance, pode-se perceber a presença do grotesco. Na comemoração ocorrida na fazenda do barão, impera o exagero pantagruélico. No caso da posse de Teobaldo, temos uma festa pública, onde o privado é invadido pelo público de maneira quase carnavalesca, com

\footnotetext{
${ }^{316}$ KAYSER, Wolfgang. O grotesco, configuração na pintura e na literatura. São Paulo: Perspectiva, 2003, p. 18. Obra originalmente publicada em 1957, p. 102.

${ }^{317}$ AZEVEDO, Aluísio. O Coruja. São Paulo: Livraria Martins Editora, 1963, p. 338.

${ }^{318}$ Idem, p. 339.
} 
direito a banda de música, que toca o Hino Nacional. A descrição do corpo claudicante de André dá aspecto ainda mais grotesco à passagem. Na casa de dona Margarida, a opulência dos pratos servidos contrasta com miserabilidade em que vivem os moradores, e a doença da dona da casa acentua o grotesco da cena.

\subsection{A crise nervosa deflagradora do choque perceptivo}

Doenças nervosas, como a histeria, sempre estiveram na ordem do dia dos romances naturalistas. Esse é o tema central de Thérèse Raquin, de Émile Zola, e de alguns romances do próprio Aluísio, dos quais $O$ homem (1887) é o exemplo mais contundente. ${ }^{319}$

Ao classificar o "grotesco chocante", Muniz Sodré e Raquel Paiva defendem a ideia de que ele pode se dar por meio da festa ou da loucura, tendo como objetivo principal o choque perceptivo. Ou seja, romper com a ordem, geralmente tendo em vista uma intenção sensacionalista.

Faremos o levantamento da presença das chamadas "doenças nervosas" na obra em estudo para verificar em que medida poderemos afirmar que Aluísio Azevedo utilizou-se do grotesco para provocar o choque perceptivo, tendo em vista a suspensão da narrativa para prender a atenção do leitor e garantir a leitura do próximo capítulo, já que $O$ Coruja foi escrito inicialmente como folhetim.

Tema recorrente na psiquiatria, a histeria sempre esteve associada às anomalias da sexualidade. No final do século XIX, era recorrente a ideia de que se tratava de uma doença eminentemente feminina. "Partia-se do princípio de que, por natureza, na mulher, o instinto materno anulava o instinto sexual e, consequentemente, aquela que sentisse desejo ou prazer sexual seria, inevitavelmente, anormal." ${ }^{320}$

\footnotetext{
${ }^{319}$ Nesse romance, a personagem Madalena, ao saber que está apaixonada pelo próprio irmão bastardo, é acometida por uma crise nervosa que progride até a alienação absoluta. Ana Rosa, personagem de $O$ mulato, tem forte crise histérica quando acredita ter sido abandonada pelo amante. A histeria também acomete Olímpia e Nini, respectivamente personagens de Girândolas de amores e Casa de pensão.

${ }^{320}$ ENGEL, Magali. "Psiquiatria e feminilidade." In: DEL PRIORE, Mary. História das mulheres no
} 
Tanto nos estudos psiquiátricos como nos romances naturalistas, a histeria teve como foco a mulher. ${ }^{321}$ Mas como veremos, em menor extensão, as personagens masculinas da obra em análise também são acometidas por crises nervosas, ainda que não caracterizadas como histéricas. Por exemplo, Teobaldo tem uma pequena enfermidade nervosa, quando se vê desprovido de recursos financeiros e não consegue fixar-se em qualquer ofício:

A surda aflição que lhe punha no espírito a sua falta de recursos, a força de reproduzir-se, havia já se convertido em estado patológico, numa espécie de enfermidade nervosa, que o trazia sempre desinquieto e lhe dera o hábito de levantar de vez em quando o canto do lábio superior com um certo trejeito de impaciência. ${ }^{322}$

Picuinha também é acometido por "violento ataque de nervos," 323 que o deixa acamado por dias. Em outras ocasiões, quebra toda a louça da casa. Mas, no caso dele, as crises são creditadas ao alcoolismo.

Entretanto, nas personagens femininas esses ataques ganham maior proporção. Quatro mulheres são vitimadas pelos nervos: a mãe de Teobaldo, Ernestina, Leonília e Branca. Como veremos, os danos provocados pelas crises são diferentes e a descrição que o narrador faz delas também. Mas o estado enfermiço dessas mulheres tem o mesmo motivo deflagrador: o amor dedicado a Teobaldo.

A primeira descrição de uma crise nervosa é a que acomete Laura, a Santa, como também era chamada a mãe de Teobaldo. Inconformada com a ideia de separar-se do filho, que vai estudar na Corte, ela tem uma crise de nervos. Como tenta explicar o jovem em diálogo com Sampaio. Ao ser questionado sobre a saúde da mãe, responde:

Brasil. São Paulo: Unesp/Contexto, 2008, p. 340.

321 "A partir da segunda metade do século XIX as teorias em torno da histeria, formuladas por alienistas europeus, sobretudo franceses, tornaram-se cada vez mais sofisticadas e, ainda que suscitando inúmeras controvérsias, a maior parte delas tendia a se circunscrever num universo comum, relacionando a sede e a natureza da moléstia ao sistema nervoso, ao cérebro e à degenerescência. Essas perspectivas seriam cada vez mais difundidas entre os alienistas e médicos brasileiros, sobretudo a partir dos anos de 1870. A análise da produção desses especialistas revela, contudo, que a ruptura com as concepções que destacavam o útero na definição da moléstia não implicaria numa dissociação absoluta e completa entre histeria e mulher, já que a primeira continuaria sendo concebida como uma doença eminentemente feminina. ENGEL, Magali. "Psiquiatria e feminilidade." In: DEL PRIORE, Mary. História das mulheres no Brasil. São Paulo: Unesp/Contexto, 2008, p. 344.

${ }_{322}$ AZEVEDO, Aluísio. O Coruja. São Paulo: Livraria Martins Editora, 1963, p. 159-160.

${ }^{323}$ Idem, p. 324. 
“- Não sei. Uma complicação. Nervoso principalmente”. ${ }^{324}$

As crises nervosas de Branca também são descritas de maneira bem sutil. Ao descobrir a traição do marido com a esposa de um Conselheiro, ela entristece profundamente. Em vez de confrontar Teobaldo sobre a questão, finge ter um achaque nervoso. Ele tenta uma aproximação afetiva, mas Branca recusa-o e afirma que tal capricho dos nervos durará enquanto ela viver.

Na verdade, não se trata de uma perturbação nervosa, mas de uma grande decepção diante da descoberta que acabara de fazer sobre o marido e outras pessoas da sociedade, como o Conselheiro, que ignora a denúncia da traição feita por ela. A esposa traída usa um interessante artifício para indicar suas descobertas. Longe de acusar claramente o consorte, alega ter tido um sonho, em que todos usam máscaras, inclusive ela, a máscara da inocência, que deixa cair ao final do sonho, quando passa a ver as pessoas como realmente são, sobretudo o marido, que não passa de um homem "vulgar, sem coração, sem talento e sem dignidade!" 325

Desde então, Branca passa a tratar o marido com inalterável frieza. Portanto, apesar de não ter sido acometida por uma crise nervosa ou pela loucura, mas ter pela primeira vez visto o seu entorno com a clareza da razão, dissimula seu comportamento no que chama de "caprichos dos nervos". 326

Mais adiante, Branca tem outra crise, que culmina com um estado febril, quando é assediada pelo primo. Mas logo se restabelece e vai exigir do marido que liquide a dívida contraída com Aguiar. Portanto, no caso de Branca, os distúrbios nervosos ou são simulados, para não enfrentar o marido, ou imediatamente contidos pela razão, como manda a firmeza de seu caráter.

Em Leonília, cortesã de alto nível, ataques de nervos são evidenciados com mais vigor. Na carta que escreve para Teobaldo, declara logo depois que o vê com Ernestina:

Ao chegar em casa, ardia em febre; à noite não pude me levantar da cama, [...] Não sei qual é a minha moléstia, posso apenas afiançar que

\footnotetext{
${ }^{324}$ AZEVEDO, Aluísio. O Coruja. São Paulo: Livraria Martins Editora, 1963, p. 74.

${ }^{325}$ Idem, p. 282.

${ }^{326}$ Idem, p. 279.
} 
estou muito doente, nervosa a um ponto de fazer lástima, sem comer e sem poder dormir; a boca muito amarga, a caixa do peito muito dorida, e a causa de tudo isso - és tu. ${ }^{327}$

A longa missiva, de onde retiramos o trecho acima, não foi enviada ao destinatário, mas encontrada por ele dentro de um livro. Toda a crise nervosa descrita na carta é substituída por um bilhete, em que Leonília alega deixar o amante por interesses particulares e que parte para a Europa, pois assim pede seu temperamento inconstante.

Podemos observar que, apesar de nesse caso termos até a descrição fisiológica da crise de nervos, a simulação ainda permanece. O orgulho da cortesã impede que ela exponha suas dores de alma ao amante, por isso substitui a carta. Todavia, o narrador só nos deixa ler a verdade pelos olhos de Teobaldo, para que possamos vê-lo sorrir ao dizer: “- Coitada! disse consigo. - Foi infeliz! Esqueceu-se de inutilizar a outra carta, sem o que talvez produzisse esta o efeito a que se destina. Definitivamente não nasci para sofrer pelas mulheres!...". 328

O simulacro de perturbação nervosa também foi expediente usado por Leonília, talvez para dispensar um de seus amantes e ficar com o filho do barão. Pelo menos é o que indica o diálogo em que se recordam do passado:

- Recordas-te ainda aquela ceia que engendramos em casa do teu cocheiro? perguntou Leonília rindo.

- Quando voltávamos de um passeio à Cascatinha?... reforçou ele; não, não me lembro nem devo lembrar-me.

- E daquele baile carnavalesco em que me obrigaste a fingir um ataque de nervos por causa do velho Moscoso?... ${ }^{329}$

Não obstante, certamente é no caso de Ernestina que as crises nervosas chegam ao ápice e pela primeira vez são nomeadas de histeria. $\mathrm{O}$ retorno dessa personagem na narrativa, de maneira inesperada, dois anos depois de ter sido deixada por Teobaldo nos braços do sr. Almeida, provoca uma verdadeira reviravolta na história. No folhetim

\footnotetext{
${ }^{327}$ AZEVEDO, Aluísio. O Coruja. São Paulo: Livraria Martins Editora, 1963, p. 166.

${ }^{328}$ Idem, p. 167.

${ }^{329}$ Idem, p. 124.
} 
prioriza-se a ação como unidade narrativa que alavanca o enredo. Aluísio Azevedo é bastante consciente disso. Daí, a recorrência de reviravoltas inesperadas, provocadas por idas e vindas das personagens Ernestina e Leonília na vida de Teobaldo e, consequentemente, na trama romanesca.

Além desse toque rocambolesco, bem próprio do folhetim, a presença de Ernestina volta a ser um importante fiel da balança, que mostra as diferenças de caráter entre Teobaldo e André. Também são os recursos financeiros deixados por ela que permitirão a Teobaldo viver até conquistar o coração de Branca.

As crises nervosas dessa mulher são descritas de forma bastante contundente. Desfalece quando se sente trocada por Leonília e com gritos histéricos insiste em ficar na casa de Teobaldo, apesar de ser enxotada por ele. O tom grotesco da descrição da crise salta aos olhos: "A infeliz escabujava como um possesso; atirava-se fora da cama, rilhando os dentes, trincando os beiços e a língua, esfrangalhando as roupas, em um estrebuchamento que lançava por terra todos os objetos ao seu alcance". ${ }^{330}$

Enquanto Teobaldo faz a corte à doce Branca na casa do comendador Rodrigues, André tenta conter o ataque histérico de Ernestina, e a encenação grotesca continua:

Ernestina cingia-se-lhe ao corpo, peito a peito, enterrando-lhe as unhas na cerviz, mordendo-lhe os cabelos, refolgando-lhe com ânsia sobre o rosto, como em um supremo desespero de amor. E André, tonto e ofegante, sentia vertigem quando seus olhos topavam as trêmulas agitadas carnes da histérica, completamente desvestidas nas alucinações dos espasmos. ${ }^{331}$

Portanto, o ataque histérico de Ernestina tem forma convulsiva, mas com forte conotação sexual, "como um supremo desespero de amor", em que as carnes estão à mostra, por certo, deixando desconcertado o pudico André.

O ápice da crise se dá quando ela percebe que definitivamente não terá o amor de Teobaldo. Fato que confirma os estudos de Magali Engel, que assinalam que as crises de histeria decorrentes do abandono do amante são comuns no histórico de

\footnotetext{
${ }^{330}$ AZEVEDO, Aluísio. O Coruja. São Paulo: Livraria Martins Editora, 1963, p. 194.

${ }^{331}$ Ibidem.
} 
mulheres histéricas do período. ${ }^{332}$

Com muito custo Ernestina adormece, mas logo depois tem mais uma conversa com Teobaldo, que reitera não querê-la por perto. Então, a pobre mulher decide por dar cabo à própria vida. E aqui temos uma cena escrita bem nos moldes do folhetim. Ernestina tenta matar-se tomando querosene, mas arrepende-se e, ao cuspir a golfada do venenoso líquido, atinge o pavio do candeeiro e acaba tendo uma morte dolorosa. A descrição nua e crua da cena, terrivelmente grotesca, chega a ser repugnante:

Da sala até ali, por onde ela atravessava de carreira, viam-se na parede, de espaço em espaço, a forma de sua mão, desenhada com gordura derretida e pequenos pedaços de carne [...] estava horrível; o cabelo desaparecera-lhe; os olhos eram duas orlas vermelhas e ensanguentadas; a boca, totalmente deslabiada, mostrava os dentes cerrados com desespero; e dos ouvidos sem orelhas e do nariz sem ventas escorria-lhe um líquido gorduroso e amarelento. ${ }^{333}$

Pelo apontado até aqui, podemos ver que no romance em análise as crises nervosas que acometem as mulheres são de diferentes níveis. Não é por acaso que nas senhoras da aristocracia elas são apenas mencionadas e quando descritas nada têm de grotesco. Em alguns casos, são usadas como simulacro diante da dificuldade de dizer a verdade - caso de Branca, quando descobre a traição de Teobaldo.

Em Leonília, a cortesã de luxo, os achaques nervosos são descritos de maneira sutil. A falta de apetite, febre e dores no peito lembram bastante as doenças fatais que acometiam as heroínas românticas, como em Dama das Camélias e Lucíola.

Todavia, quando se trata de uma mulher de estrato social inferior, a loucura tem tonalidades grotescas, se dá por meio de gritos e o corpo é retorcido pela convulsão até se decompor pela morte acidental, mas decorrente da falta de controle dos nervos. Nesse caso, a loucura certamente transforma-se em elemento provocador da “desordenação" do mundo, como aponta Kayser:

$\mathrm{Na}$ demência, o elemento humano aparece transformado em algo

\footnotetext{
${ }^{332}$ Cf. ENGEL, Magali. "Psiquiatria e feminilidade." In: DEL PRIORE, Mary. História das mulheres no Brasil. São Paulo: Unesp/Contexto, 2008, p. 353.

${ }^{333}$ AZEVEDO, Aluísio. O Coruja. São Paulo: Livraria Martins Editora, 1963, p. 198-9.
} 
sinistro; mais uma vez é como se um id, um espírito estranho, inumano, se houvesse introduzido na alma. O encontro com a loucura é como uma das percepções primogênitas do grotesco que a vida nos impinge. ${ }^{334}$

De maneira branda ou convulsiva, as crises aqui analisadas estão de acordo com o pensamento científico recorrente à época da produção do romance, que postulava uma íntima relação entre as perturbações psíquicas e os distúrbios da sexualidade/afetividade em quase todos os tipos de descontrole mental ou crises nervosas. Não obstante, como bem pontua Sonia Brayner em estudo sobre a obra $O$ cortiço, no Naturalismo "O sexo do povo é primitivo, o do burguês é sofisticado e hipócrita, sempre pronto a usufruir gozos e lucros de qualquer transação". ${ }^{335}$ Isso parece bem exemplificado pelo casamento entre Teobaldo e Branca. Embora ela realmente estivesse apaixonada, para ele o enlace foi apenas uma maneira de ascender socialmente, como deitar com a esposa do Conselheiro permitiu-lhe conseguir alcançar mais poder político.

Pelo apresentado até aqui, fica evidente que o grotesco é elemento importante na composição do romance. Deixamos para o próximo e derradeiro capítulo aspecto fundamental para fecharmos a discussão: a dualidade complementar das personagens centrais do romance, André e Teobaldo.

\footnotetext{
${ }^{334}$ KAYSER, Wolfgang. O grotesco, configuração na pintura e na literatura. São Paulo : Perspectiva, 2003, p. 159

335 BRAYNER, Sonia. Labirinto do espaço romanesco. Rio de Janeiro: Civilização Brasileira/MEC, 1979 , p. 64.
} 


\section{CAPÍTULO 5 - O DUPLO E O GROTESCO CRÍTICO NA COMPOSIÇÃo NARRATIVA}

Como apresentado nos dois primeiros capítulos deste estudo, Aluísio Azevedo era um escritor que pensava e escrevia em consonância com seu tempo. Tivemos também o cuidado de mostrar que suas ideias abolicionistas e republicanas eram defendidas tanto nos romances e artigos, como nas charges. Conhecedor da produção de seus contemporâneos, por certo se debruçou sobre as obras de autores portugueses, sobretudo Eça de Queirós e Ramalho Ortigão, mas também leu escritores franceses, como Victor Hugo, Balzac, Zola e Flaubert, tendo traduzido obras dos dois últimos.

O papel desempenhado como jornalista contribuiu para que o escritor tivesse contato não só com a produção literária de outros países, mas também com as ideias que circulavam no velho mundo. A tão apregoada posição de que as distâncias acentuavam a defasagem do Brasil em relação à Europa que, em certa medida, justificariam o atraso cultural, é bem contestada no seguinte trecho de ensaio de Alfredo Bosi. Basta ler as seções de notícias internacionais, publicadas no jornal O Paiz, em 1885, como indicado por nós no segundo capítulo, para comprovar que isso é verídico:

A difusão de ideias concebidas nos países mais desenvolvidos do Ocidente terá tardado vinte anos, pouco mais ou pouco menos, mas à medida que se avança no século XIX, começa-se a perceber uma quase sincronia, que o telégrafo, as viagens, as leituras intensas dos jornais, revistas e livros franceses, alemães e ingleses iam facultando aos nossos intelectuais mais estudiosos e engajados. ${ }^{336}$

Essa retomada de tópicos é necessária para situar não só o livro no contexto da produção aluisiana, mas também para reafirmar a hipótese de que as ideias filosóficas, literárias e políticas que circulavam na Europa eram absorvidas com frequência por nossos escritores e intelectuais.

É importante também reiterar que a presença do grotesco na obra em análise não

\footnotetext{
${ }^{336}$ BOSI, Alfredo. "A cultura no Brasil império: literatura e ideias". In: CARVALHO, José Murilo de (Org.). Construção nacional: 1830-1889. Rio de Janeiro: Objetiva/Fundación Mapfre (1830-1889), 2012, p. 258.
} 
pode ser demarcada por influência dessa ou daquela escola literária. Todavia, o percurso feito por nós até o momento foi fundamental para entendermos a complexidade dessa categoria estética e a maneira como ela foi usada na tessitura de um romance de formação, que culmina com uma visão desencantada do mundo, mediada por certo pessimismo.

Neste capítulo, analisaremos como o grotesco foi utilizado para configurar a trajetória formativa de André e Teobaldo, ainda que essa formação tenha resultado bem diverso da concepção modelar do Bildungsroman.

Trataremos da duplicidade presente no romance, para verificar em que medida a relação entre as personagens principais vai sendo permeada pelo entorno onde estão inseridas, até culminar na visão desencantada do mundo. Pois, como bem observa Raimundo de Menezes sobre a estrutura do romance $O$ Coruja, o escritor divide a obra em três partes, sendo que na derradeira percebe-se a influência do pessimismo de Arthur Schopenhauer:

\begin{abstract}
Na primeira descreve a vida num internato (mais tarde, Raul Pompéia exploraria o mesmo tema no seu famoso $O$ Ateneu); na segunda, encontra-se qualquer coisa que lembra Casa de pensão (talvez o romancista se utilize do resto do material que andou colhendo e que ainda possuía); na terceira e última parte, constituída de páginas bem amargas, à Schopenhauer, dá-nos um desfecho dos mais cruéis. ${ }^{337}$
\end{abstract}

\title{
5. 1. Um preâmbulo sobre o duplo
}

O pessimismo teve grande representação na literatura francesa desde Charles Baudelaire, mas é com a divulgação do pensamento do filósofo Arthur Schopenhauer (1788-1860) que o assunto ganha maior notoriedade. O conceito central do pessimismo schopenhaueriano está associado à vontade. Para ele, a vontade seria o princípio fundamental da natureza que, irracional e cega, vai encontrando formas no mundo até

337 MENEZES, Raimundo de. Aluísio Azevedo, uma vida de romance. São Paulo: Livraria Martins Editora, 1958, p. 206. 
manifestar-se no homem.

O pensamento de Schopenhauer culmina no pessimismo porque, se tudo se encerra no querer, desejar nada mais é do que o sofrer pela falta daquilo que se deseja. A vontade insatisfeita faz com que o sofrimento permaneça e aumente. Por sua vez, o desejo realizado conduz invariavelmente ao tédio absoluto:

Todo querer se origina da necessidade, portanto, da carência, do sofrimento. A satisfação lhe põe um termo; mas para cada desejo satisfeito, dez permanecem irrealizados. Além disto, o desejo é duradouro, as exigências se prolongam ao infinito; a satisfação é curta e de medida escassa. O contentamento finito, inclusive, é somente aparente: o desejo satisfeito imediatamente dá lugar a um outro; aquele já é uma ilusão conhecida, este ainda não. Satisfação duradoura e permanente, objeto algum do querer pode fornecer $[\ldots]^{338}$

Para o filósofo, a tragicidade da vida humana estaria justamente na oscilação entre o sofrimento e o tédio. A felicidade nada mais seria que esse intervalo fugaz e tênue situado entre a satisfação de um desejo e a busca por outro. Logo, a vontade seria a fonte de todo padecimento.

Essa obsessão pelo caráter de doutrina metafísica ou moral, segundo a qual os aspectos maus ou negativos da existência superam os bons ou positivos, terá suas repercussões na produção brasileira. ${ }^{339}$ É recorrente, por exemplo, nos textos em que Araripe Júnior analisa a obra de Machado de Assis e Raul Pompéia.

Todavia, veremos que muito desse pessimismo pode ser encontrado também em O Coruja, sobretudo ao final do romance, quando assistimos à derrocada de Teobaldo, perdido nas trevas das aparências e ilusões. Como mostra essa frase, saída da boca da própria personagem: “- Como a vida é horrível! pensou ele; como tudo que ambicionamos nada vale, uma vez alcançado! Como eu me sinto farto e desprendido de

\footnotetext{
${ }^{338}$ SCHOPENHAUER, Arthur. "O mundo como vontade e representação" In: Schopenhauer. São Paulo: Abril, 1980, p. 33. (Coleção os Pensadores.)

${ }^{339}$ Segundo Sonia Brayner, a assimilação das ideias de Schopenhauer no Brasil se deu sobretudo por meio do ensaio Parerga e Paralipomena, bastante divulgado no último quartel do XIX. Nesse texto, o filósofo "lamenta a nebulosidade de pensamento e o estilo empesé, apontando a simplicidade como a verdadeira marca de verdade do gênio ". In: BRAYNER, Sonia. Labirinto do espaço romanesco. Rio de Janeiro: Civilização Brasileira/MEC, 1979, p. 257.
} 
tudo aquilo que até hoje me interessava e me comprazia! Afinal, do que serve existir? Para que viver?" 340

A ênfase na queda do homem, em decorrência desse caráter radicalmente perdido, gerará ações dúbias, interesses mesquinhos que, por sua vez, estimularão, sobretudo a partir da segunda metade do século XIX, o uso de temas narrativos nos quais prevalecerão a dualidade e os sentimentos contraditórios.

Em $O$ pintor da vida moderna, Charles Baudelaire ${ }^{341}$ defende a ideia de que a "dualidade da arte é uma consequência fatal da dualidade do homem". ${ }^{342}$ De certa forma, essa premissa está em concordância com o fato de o duplo ser recorrente na ficção de diferentes períodos, gêneros e localidades.

Todavia, foi sobretudo no século XIX que o duplo ganhou espaço preponderante na literatura, ainda que o tema já estivesse presente na Antiguidade. Basta nos lembrarmos da personalidade cindida de Édipo, em busca da verdadeira identidade; de Narciso, apaixonado pela própria imagem refletida nas águas de um lago; ou do princípio da androgenia, defendido no Banquete de Platão.

Contudo, se o tema da duplicação é bem antigo, somente a partir do Romantismo a questão ganhará maior relevância na produção literária de diferentes povos. Está presente em Pierre e Jean, de Maupassant; em O retrato do Dorian Gray, de Oscar Wilde; em $O$ duplo, de Dostoiévski; no clássico da literatura de terror $O$ médico e o monstro, de Stevenson; na personagem Lucíola, de José de Alencar, como ainda na obra Esaú e Jacó, de Machado de Assis. A lista é extensa, como também não são poucas as diferentes perspectivas analíticas.

Na produção aluisiana, o duplo é tema do romance A mortalha de Alzira (1891). Nessa obra, o casto padre Ângelo apaixona-se perdidamente pela cortesã Alzira. Depois

\footnotetext{
${ }^{340}$ AZEVEDO, Aluísio. O Coruja. São Paulo: Livraria Martins Editora, 1963, p. 353.

${ }^{341}$ Ao analisar as diferenças entre a poética de Baudelaire e seus antecessores românticos, Hugo Friedrich postula que o poeta francês desejou sinceramente a feiura como equivalente do novo mistério "a penetrarse como ponto de ruptura para a ascensão à idealidade". Em Baudelaire, o grotesco nada tem de cômico, e do embate com o diabólico surge o conceito de absurdo, em que as dissonâncias e os contrastes são usados para provocar o choque nervoso e desagradar o leitor. FRIEDRICH, Hugo. A estrutura da lírica moderna. São Paulo: Duas Cidades, 1991, p. 44.

${ }_{342}$ BAUDELAIRE, Charles. "O pintor da vida moderna". In: Poesia e prosa. Rio de Janeiro: Nova Aguilar, 2006, p. 853.
} 
da morte da amante, o clérigo passa a ter sonhos em que a virgem santíssima transforma-se na adorada prostituta. A duplicidade está presente na representação feminina, já que Alzira ora é a virgem imaculada, ora a mulher sedutora, mas também na condição de Ângelo. Conflitado entre as obrigações religiosas, que exigem dele pureza e castidade, e os desejos carnais, provocadores de crises de consciência, o padre acaba acometido pela loucura, que o leva ao suicídio.

A manifestação da duplicidade pode estar presente na concepção da mesma personagem, caso de $O$ médico e o monstro e Lucíola, ou projetada em duas personagens com características aparentemente antagônicas, como veremos no romance em estudo. Em qualquer das possibilidades, cria-se um jogo de situações complexas, que podem fornecer denso arremate psicológico à trama da criação literária.

Isso posto, no próximo item trataremos da construção das personagens centrais do romance, tendo o duplo como principal elemento, mas mediado pelas ideias de Schopenhauer.

\section{2. O duplo na construção das personagens centrais do romance}

Nas páginas dedicadas ao livro O Coruja, o biógrafo de Aluísio Azevedo, JeanYves Mérian, aponta uma ausência nos estudos críticos: o fato de nenhum pesquisador ter notado o díptico André/Teobaldo. ${ }^{343}$

Segundo ele, a contraposição entre as duas personagens foi uma maneira encontrada pelo escritor para denunciar os abusos do governo, que permitia a ascensão de pessoas inescrupulosas como Teobaldo. Embora concordemos com essa colocação, pois realmente a retidão de caráter e a bondade de André tornam mais evidentes as falhas morais e éticas de Teobaldo -, acreditamos que o uso do duplo na construção das personagens centrais do romance merece ser aprofundado. Trataremos, portanto, dessa contraposição, mas verificando em que medida ela traz, imbricada no seu cerne, certa

\footnotetext{
${ }^{343}$ MÉRIAN, Jean-Yves. Aluísio Azevedo, vida e obra (1857-1913): O verdadeiro Brasil do século XIX. Rio de Janeiro: Espaço e Tempo, 1988, p. 511.
} 
complementaridade e por que essa situação muda ao longo da narrativa.

A despeito das evidentes diferenças entre as duas personagens, o narrador sinaliza, já na primeira parte do romance, que os amigos se completam:

Uma vez reunidos, completavam-se perfeitamente. Cada um dispunha daquilo que faltava no outro; Teobaldo tinha a compreensão fácil, a inteligência pronta; Coruja o método, e a perseverança no estudo; um era rico; o outro econômico; um era bonito, débil e atrevido; o outro feio, prudente e forte. Ligados, possuiriam tudo. ${ }^{344}$

Entretanto, veremos que o processo de formação, longe de levá-los para a realização plena, advinda dessa possibilidade de juntos "possuírem tudo", os conduz a um final infeliz.

As diferenças entre os amigos de infância podem ser observadas tanto na caracterização física, como psicológica. A primeira descrição de Teobaldo é feita justamente em comparação com a de André: "O tipo desta criança fazia um verdadeiro contraste com o do Coruja. Era débil, espigado, de uma palidez de mulher; olhos negros, pestanudos, boca fidalga e desdenhosa, principalmente quando sorria e mostrava a pérola dos dentes". 345

No período de férias, desfrutado pelos amigos na fazenda dos pais de Teobaldo, o narrador apresenta várias situações em que as diferenças entre os garotos são evidenciadas. Por exemplo, durante uma prática de montaria, Teobaldo cavalga em um elegante alazão, enquanto André prefere um burro, contrariando a vontade do amigo, que insistira para que utilizasse um animal nobre.

As diferenças de temperamento também fazem com que André prefira a calmaria da pesca, mais adequada ao seu tipo tranquilo e reflexivo, enquanto Teobaldo tem predileção pelo alvoroço e as surpresas das caçadas:

Era interessante ver aqueles dois meninos, tão contrários e tão unidos,

\footnotetext{
${ }^{344}$ AZEVEDO, Aluísio. O Coruja. São Paulo: Livraria Martins Editora, 1963, p. 39.

${ }^{345}$ Idem, p. 31.
} 
partirem de madrugada para o mato, onde passavam quase sempre as melhores horas do dia. André carregava consigo os utensílios da pesca e raro dizia uma palavra enquanto matejava; o outro, com a sua passarinheira a tiracolo, falava por si e por ele, descrevendo entusiasmado as façanhas do pai ou do avô. ${ }^{346}$

Para Teobaldo, o campo era apenas um fundo pitoresco, onde desfilava sua figura fidalga. Daí, a grande importância dada à roupa que usaria em determinada atividade, às armas utilizadas em uma caçada ou à elegância do animal que montaria, como se tudo fizesse parte de um figurino:

Ele nunca saía a passear sem suas trabalhadas botas de polimento, sem o seu calção de flanela, a sua blusa abotoada até o pescoço e cingida ao estômago por um cinturão com fivela de prata; não saía sem seu chapéu de pluma, a sua bolsa de caça, o seu polvorinho, o seu chumbeiro e, ainda que tivesse a certeza de não precisar da espingarda, levava-a, porque a espingarda fazia parte do figurino. ${ }^{347}$

Em oposição, André, usando roupas ordinárias e um chapéu de palha, percorria a fazenda em busca de alguém que pudesse lhe ensinar o nome de cada árvore e o processo empregado na cultura de determinada plantação.

$\mathrm{Na}$ primeira parte do romance, são muitos os exemplos que mostram as personagens em contraposição. $\mathrm{O}$ narrador, sempre que descreve as atividades realizadas pelos amigos, acentua tanto as diferenças físicas, como as de temperamento.

Cabe lembrar ainda que foi o universo escolar que uniu de modo fraterno essas duas personagens de origens sociais tão distintas. Teobaldo era filho da aristocracia rural e André, órfão do "obscuro e já esquecido" procurador Miranda. A escola poderia ter acentuado ainda mais essa desigualdade, sobretudo graças às atitudes do diretor Mosquito, que geria aquele internato mais como um negócio rentável do que um centro educacional. Contudo, como vimos no terceiro capítulo, as dificuldades enfrentadas pelos garotos, diante das ameaças de seus condiscípulos, acabam unindo-os em uma

\footnotetext{
${ }^{346}$ AZEVEDO, Aluísio. O Coruja. São Paulo: Livraria Martins Editora, 1963, p. 31.

${ }^{347}$ Idem, p. 58.
} 
amizade que perdurará durante todo o romance.

Desde as primeiras páginas, o narrador demarca a decalagem social entre os amigos e, com frequência, reforça também a ideia de que as condições decorrentes dessas diferenças de nível social favoreciam o desenvolvimento de determinados talentos em detrimento de outros.

Teobaldo desfrutava de todas as regalias sociais como filho da aristocracia rural que era, mas o narrador faz questão de mencionar também o determinismo da hereditariedade na caracterização da personagem. Aspecto tão caro aos naturalistas, como mostra a seguinte passagem:

Passadas as primeiras épocas depois da morte dos pais de Teobaldo, o verdadeiro temperamento deste, aquele temperamento herdado do velho cavalheiro português e da cabocla paraense, aquele temperamento mestiço agravado por uma educação de mimos e liberdades sem limites, começou a ressurgir como o sol depois da tempestade. ${ }^{348}$

André, por sua vez, é a encarnação do senso da realidade, ingênuo, simplório, detentor de sólido senso de justiça e lealdade, apresenta, desde a mais tenra idade, grande disposição para o trabalho e um desejo de investigação apurado.

A Teobaldo é atribuído, com certo viés crítico, a necessidade de aderir ao que está na moda. Na meninice, isso pode ser notado nos apetrechos que usava nas atividades esportivas praticadas no campo, como visto anteriormente; na juventude e maturidade, transforma-se em um seguidor de todas as novidades que surgiam:

Assim, durante algum tempo, só o ouviram falar em magnetismo, e parecia resolvido a não pensar em outra coisa, daí em diante; depois veio o espiritismo, e Teobaldo durante outro período foi o mais fervoroso discípulo de Allan Kardec; depois passou a dedicar-se à astronomia; depois à maçonaria e, entre os vinte e os trinta anos, pertenceu sucessivamente àquilo que mais estivesse na moda. ${ }^{349}$

\footnotetext{
${ }^{348}$ AZEVEDO, Aluísio. O Coruja. São Paulo: Livraria Martins Editora, 1963, p. 122.

${ }^{349}$ Idem, p. 249.
} 
O tema do duplo em geral, e da duplicidade em particular, não é gratuito. Terá desdobramento constante na construção da narrativa. Nota-se na predisposição para o binário, que o narrador começa a história acreditando na cristalização de uma mesma essência em duas pessoas distintas, questão implícita, por exemplo, na frase "juntos teriam tudo". E essa centralidade de toda a trama em torno dos amigos prossegue na segunda parte do romance. Ali, ainda prevalece a ideia de que as duas personagens se complementavam. Durante a montagem da casa onde vão morar em Mata-cavalos, Teobaldo se encarrega da escolha da mobília com muito critério e bom gosto, mas é André, com seu senso de praticidade, que mantém o lugar sempre limpo e em ordem.

O Coruja não tinha vícios e envergonhava-se por ser tão puro, enquanto Teobaldo reunia com frequência os amigos em casa para beber, fumar charutos e discutir diversos assuntos. Se havia alguma sobriedade naquele lugar, ela se encontrava na mesa de estudos de André. Espaço sagrado que o filho do barão fazia questão de preservar, mesmo durante as noites de pândega, como mostra esta passagem: "Mas, sempre que algum dos rapazes se aproximava da mesa de André, que estava ausente, Teobaldo exclamava desviando-o: "Não! aí não mexam! É a mesa do Coruja!”350

Pelo posto até aqui, pode-se notar que as ideias postuladas por Victor Hugo sobre o grotesco e o sublime também são observáveis no romance $O$ Coruja. Ou seja, a beleza não é associada ao bem e a feiura, ao mal. Na obra de Aluísio, o fenômeno da inversão, proposta por Hugo, também contradiz a relação tradicional.

Para exemplificar essa questão, usaremos novamente o romance $O$ corcunda de Notre-Dame. Nessa obra, Quasímodo feio, corcunda, totalmente desprovido de graça é incapaz de ser hipócrita. Apresenta-se aos nossos olhos como a antítese de seu mestre, o padre Claude Frollo, sempre sinistro, vaidoso e dissimulado. André, com seu corpo grotesco e excessiva fealdade, transforma-se na própria encarnação da bondade, enquanto Teobaldo, a despeito da beleza e elegância, mostra-se vaidoso e inescrupuloso.

Mas, no caso da obra aluisiana, há um avanço nessa questão da oposição beleza/vaidade, em contraposição à feiura/bondade. As boas ações de Quasímodo são despertadas pelo apreço que tem por Esmeralda, que passa a ser a única merecedora

${ }^{350}$ AZEVEDO, Aluísio. O Coruja. São Paulo: Livraria Martins Editora, 1963, p. 91. 
delas. Bem diferente é o caso de André. A bondade é inerente ao seu caráter e todos, inclusive o desconhecido fugitivo que invade seu quarto, são beneficiados por ela.

Podemos concluir, então, que sob a figuração corpórea grotesca desse tipo desprezado e machucado por todos, prevalece o desejo de praticar o bem. Por sua vez, o vaidoso, egoísta e ambicioso Teobaldo é envolvido pela couraça de um corpo belo e em tudo gracioso. Esse contraste entre o exterior e interior na composição dos dois amigos configura-se como um dos temas fortes do livro.

No texto Sobre o fundamento da moral (1841), Schopenhauer defende a ideia de que bondade ou maldade são sentimentos inatos nos indivíduos. Por conseguinte, a ética nada poderia fazer para tornar o homem maldoso em compassivo, ou vice-versa, dado que esses distintos modos de proceder seriam inatos e indeléveis:

Se a compaixão é a motivação fundamental de toda justiça e caridade genuínas, quer dizer, desinteressadas, por que uma pessoa e não outra é por ela motivada? Pode a ética, já que descobre a motivação moral, fazê-la atuar? Pode ela transformar um coração duro num compassivo e, daí, num justo e caridoso? Por certo não; [...] A maldade é tão inata ao maldoso como o dente venenoso ou a glândula venenosa da serpente. Também como ela não pode mudar. [...] A virtude não é nem inata nem ensinável, mas distribuída pela sorte divina e sem entendimento àqueles que foram sorteados. ${ }^{351}$

Enquanto André pode ser enquadrado na categoria chamada por Schopenhauer de motivação compassiva, ${ }^{352}$ Teobaldo é quase sempre guiado pela motivação maldosa. Os homens classificados nessa segunda categoria consideram as outras pessoas como meros objetos, usados em prol da realização de seus próprios interesses.

Essa motivação maldosa se dá porque o indivíduo está de tal forma centrado em si mesmo, que o aniquilamento do outro poderia até mesmo levá-lo a praticar injustiças. Isso se daria de duas maneiras, pela força física ou por meio da persuasão. Ou seja, o

351 SCHOPENHAUER, Arthur. Sobre o fundamento da moral. Trad. Maria Lúcia Mello e Oliveira Cacciola. São Paulo: a Martins Fontes, 2001, p. 190-191.

352 "A motivação compassiva é aquela que impulsiona os homens para ações que têm como finalidade o bem alheio. Diferente da justiça, que somente impede que um homem faça mal a outrem, a compaixão impele o indivíduo a ajudar aquele que necessita, mas a compaixão só será genuína se totalmente desprovida de egoísmo". Idem, p. 160. 
homem maldoso manipularia o outro, de maneira a colocá-lo a seu serviço ou tomandolhe algum bem, por exemplo, o fruto de seu trabalho:

Sem dúvida, nesses moldes, o praticante da injustiça, ao atacar não um corpo alheio, mas uma coisa sem vida, totalmente diferente dele, invade do mesmo modo a esfera de afirmação estrangeira da vontade, pois as forças, o trabalho do corpo alheio, por assim dizer, confundem-se e identificam-se com essa coisa. ${ }^{353}$

A manipulação de André por parte de Teobaldo é bastante recorrente no romance. $\mathrm{O}$ filho do barão não apenas é invariavelmente socorrido financeiramente pelo amigo, como promete ajudá-lo a publicar sua História do Brasil, mas acaba se apropriando das notas escritas pelo Coruja para escrever artigos que publica em jornais e, posteriormente, são coligidas em um livro de sua autoria.

As diferenças entre as duas personagens vão sendo apresentadas por um narrador distanciado, que descreve as dessemelhanças tanto físicas como psicológicas, perpassando a infância e a juventude. Entretanto, quando Teobaldo se dá conta de que está só no mundo e desprovido de recursos financeiros, o narrador muda a abordagem. As virtudes de André começam a provocar reflexões em Teobaldo, que, a partir de então, passa a invejar as qualidades do outro:

Teobaldo conservava ainda para com o Coruja a mesma sagrada amizade, a mesma dedicação da infância. Era tal o apreço em que tinha o amigo, que chegava a sentir remorsos de não proceder como ele. Instintivamente e a despeito dos seus dotes intelectuais e físicos, reconhecia em André uma certa superioridade moral, um certo privilegio de bondade que o tornava digno de inveja. ${ }^{354}$

Essa compreensão de Teobaldo a respeito das diferenças de caráter entre ele e o amigo será apresentada com frequência, a partir da morte do barão de Palmar. Mas ele jamais confessará a qualquer pessoa, ou mesmo ao Coruja, essa surda admiração. Exceto na discussão que tem com Leonília sobre o amor, durante a qual fala

\footnotetext{
${ }^{353}$ SCHOPENHAUER, Arthur. O mundo como vontade e representação. Trad, Jair Barboza São Paulo: Editora Unesp, 2005, p. 430.

${ }^{354}$ AZEVEDO, Aluísio. O Coruja. São Paulo: Livraria Martins Editora, 1963, p. 107.
} 
abertamente da afeição que nutre por André e enaltece sua maior virtude: ser bom.

Não obstante, ao final do diálogo, o narrador pontua: “Teobaldo tinha às vezes dessas expansões; dava para discorrer com entusiasmo sobre alguém que na ocasião o impressionava; ao passo que no dia seguinte seria capaz de fazer o mesmo por uma pessoa completamente oposta". ${ }^{355}$ Tal observação, em certa medida, desqualifica tudo o que fora dito por Teobaldo sobre André um pouco antes.

Esse recurso, conhecido como metalepse de autor, acontece quando o narrador emerge na narrativa de forma abrupta. Segundo Yves Reuter, ${ }^{356}$ esse expediente era comumente usado pelos romancistas do século XIX, sobretudo nos romances-folhetins, tendo como finalidade levar o leitor a refletir sobre certa situação ou determinado comportamento.

Contudo, não parece ser essa a posição do narrador que, com frequência, refuta as ideias emitidas por Teobaldo sobre o amigo. Esse procedimento é usado com o firme propósito de validar a vaidade de Teobaldo e, ainda que de maneira indireta, enaltecer o bom caráter de André. Isso nos leva a concordar com Salete de Almeida Cara, que, ao abordar obra de Zola, apresenta situação semelhante e conclui:

O discurso indireto livre não problematiza nenhuma das vozes, e nem a relação que se estabelece entre elas. Ao contrário disso, a mescla entre narrador e personagem acaba sendo uma forma de exposição que rebaixa os problemas implicados e expostos nas falas e, assim, rebaixa os sentidos que carregam. ${ }^{357}$

A maneira como o narrador apresenta as duas personagens demonstra certa tendência a levar o leitor a ter mais estima por André do que por Teobaldo. Poderíamos então afirmar que o tom por vezes moralista imposto ao romance pode ser visto como uma tentativa de pacto entre o narrador de Aluísio e seu leitor, com a intenção de cooptar certa cumplicidade, para que juntos assistam à derrocada fatal, não de um indivíduo, mas da classe aristocrática à qual ele pertence.

\footnotetext{
355 AZEVEDO, Aluísio. O Coruja. São Paulo: Livraria Martins Editora, 1963, p. 146.

${ }^{356}$ REUTER, Yves. Introdução à análise do romance. São Paulo: Martins Fontes, 2004, p. 81.

${ }^{357}$ CARA, Salete de Almeida. Marx, Zola e a prosa realista. Cotia: Ateliê Editorial, 2009, p. 156.
} 
Porém, antes de aprofundar esse aspecto, retomemos a questão da inveja que, no caso do romance em análise, passa a ser recíproca. Se Teobaldo nutre admiração, ainda que velada, pelo amigo, André também inveja Teobaldo, sobretudo porque jamais será amado como ele. Essa situação é bem sintetizada no trecho abaixo:

E aquelas duas criaturas, inteiramente opostas, invejavam-se em silêncio, não com essa inveja mesquinha que se transforma em raiva, mas nessa outra que produz admiração e respeito. [...] E tinham-se ambos na mesma conta de infortunosos: um por ser desejado demais e o outro por ser bom em demasia. ${ }^{358}$

Outro traço que aproxima as duas personagens é a necessidade de manter as aparências. Teobaldo, ao ver que a fortuna de Branca estava longe do que imaginara, para não se comprometer diante das pessoas da sociedade à qual pertence, aplica metade do dinheiro em luxo e investe a outra parte no comércio. Desta forma, seguia a teoria paterna: "As aparências são tudo". ${ }^{359}$ Por seu lado, André esconde de todos ao seu redor suas privações e seus desgostos,

[...] procurando ocupar no mundo o menor espaço que podia, e sempre superior aos outros, sempre além da esfera de seus semelhantes, atravessava a existência, caminhava por entre os homens sem se misturar com eles, que nem pássaro que vai voando pelo céu e apenas percorre a terra com a sua sombra. ${ }^{360}$

Teobaldo camufla suas dificuldades financeiras por orgulho, mas não é por outra razão que André também oculta de Inezinha e dona Margarida o estado de penúria em que se encontra. Ele jamais admite ter gastado suas economias para praticar o bem, mesmo quando faz isso para socorrer a futura sogra doente. Esse comportamento leva as duas mulheres a acreditarem que o Coruja havia desperdiçado seus recursos financeiros na jogatina e na pândega.

Ora, como bem nos lembra René Girard: "O orgulho mais fanático está fadado, ao menor revés, a se inclinar muito diante do outro; ou seja, ele se assemelha,

\footnotetext{
${ }^{358}$ AZEVEDO, Aluísio. O Coruja. São Paulo: Livraria Martins Editora, 1963, p. 172.

${ }^{359}$ Idem, p. 233.

${ }^{360}$ Idem, p. 237.
} 
extremamente, à humildade". ${ }^{361}$ Isso posto, estamos diante de um paradoxo: Teobaldo é orgulhoso por ser egoísta e vaidoso, mas paulatinamente começa a sentir desejo de ser bom e humilde; André é orgulhoso por altruísmo, mas progressivamente deseja ser amado como o amigo.

Esse aparente espelhamento de desejos, que tem como ponto de partida o orgulho, pode ser visto também no triângulo amoroso vivido por Teobaldo, André e Branca. O filho do barão não atira no amigo apenas por causa da carta anônima que recebera, mas porque os fatos recolhidos daqui e dali mostram certa aproximação afetiva entre sua esposa e o Coruja, ainda que fosse apenas uma relação platônica.

Importante lembrar que, movido pela vaidade, Teobaldo põe a perder seu casamento. Pouco fica em casa, depois que decide ter projeção política. Isso favorece a aproximação entre André e Branca. O nível de intimidade chega a tal ponto que a moça revela ao Coruja as chantagens de Aguiar e não ao marido.

Por que Teobaldo se precipita e atira em André? Porque, devido à sua excessiva vaidade e ao seu orgulho narcisista, que fazem dele o centro das atenções, não suportaria ser trocado pelo amigo, feio e desprovido de talentos. Atira não porque ama a esposa, mas porque seu orgulho ferido assim o exige. E aqui podemos nos valer das palavras de Clément Rosset:

No fundo, o erro mortal do narcisismo não é querer amar excessivamente a si mesmo, mas, ao contrário, no momento de escolher entre si mesmo e seu duplo, dar preferência à imagem. [...]

Este é o miserável segredo de Narciso: uma exagerada atenção ao outro. Esta, aliás, é a razão porque ele é incapaz de amar alguém, nem o outro nem ele mesmo, já que o amor é um assunto importante demais para que se delegue a outro a responsabilidade de negociálo. ${ }^{362}$

Essa dificuldade de amar todas as mulheres que participaram de sua educação sentimental é recorrente na obra, mas a frase seguinte é suficiente para referendá-la:

${ }^{361}$ GIRARD, René. A crítica do subsolo. Rio de Janeiro: Paz e Terra, 2011, p. 72.

${ }^{362}$ ROSSET, Clément: O real e seu duplo. Porto Alegre: L\&PM, 1988, p. 77. 
"Definitivamente não nasci para sofrer pelas mulheres..." 363

À medida que as personagens envelhecem, a narrativa ganha maior densidade. Os diálogos ficam mais longos e as diferenças ressaltadas são mais de ordem psicológica do que física. As longas descrições dos temperamentos das personagens durante a infância e juventude dão lugar a frases despidas de floreios e, pela primeira vez, a caracterização física de Teobaldo recebe tons grotescos:

A sua larga fronte, já despojada de cabelos até ao meio do crânio, raiara-se de longas rugas paralelas, como um horizonte no crepúsculo que se enfaixa de nuvens sombrias; seus grandes olhos, dantes tão insinuantes e lisonjeiros, amorteciam agora em uma profunda expressão de mágoa sem esperanças de consolo; seus lábios pareciam cansados de sorrir para todo o mundo e, como já não tinham forças para fingir, quedavam-se em uma imobilidade cheia de tédio e desdém; e todo o seu aspecto, ao contrário do que fora, servia agora muito mais para fazer pena do que para seduzir. ${ }^{364}$

A crise existencial finalmente acomete Teobaldo, que, do alto dos seus 40 anos, conclui nada ter feito, pois todos os seus talentos foram colocados a serviço apenas de sua excessiva vaidade. Essa situação é bem representada na imagem de um espelho partido, como tão bem demonstra o narrador na seguinte passagem:

Seu ideal era um espelho, onde só a sua imagem se refletia; quebrado esse espelho, ele não tinha coragem de encarar os pedaços, porque em cada um via ainda, e só, a sua figura, mas tão reduzida e tão mesquinha que, em vez de lhe causar orgulho como outrora, causavalhe agora terríveis dissabores. ${ }^{365}$

Nesses fragmentos de espelho, o que Teobaldo vê com melancolia amarga é o esfacelamento de uma vida inteira dedicada apenas aos ímpetos da vaidade. Essa tomada de consciência tardia deflagra uma crise moral que acaba levando-o à negação niilista da vida e do mundo e, consequentemente, à morte prematura.

\footnotetext{
${ }^{363}$ AZEVEDO, Aluísio. O Coruja. São Paulo: Livraria Martins Editora, 1963, p. 172.

364 Idem, p. 349.

${ }^{365}$ Idem, p. 167.
} 
No caso dele, toda a realidade é aniquilada, porque nada além da vontade guiava seu ser excessivamente vaidoso. Como bem conclui o próprio personagem nas páginas finais do romance: "Ser tão pouco, quanto tanto se ambiciona; ambicionar tanto e ter certeza de nunca ir além da própria pequenez, é muito mais doloroso, é muito mais cruel do que ficar eternamente sucumbido ao peso da primeira ilusão!"366

Em contrapartida, André é um sobrevivente, ainda que emoldurado em um corpo grotesco e claudicante. Se podemos ver traços do pessimismo schopenhaueriano também no Coruja, poderíamos dizer que esta personagem estaria enquadrada no que o filósofo chamou de purificação ética,

mediante a qual o homem, pelo exercício da justiça e da caridade, mortifica a sua vontade de viver, o seu egoísmo, que o separava dos outros homens, impelindo-os até à perversidade. Isto é, o homem se sente, pela compaixão - que, segundo Schopenhauer, é a raiz próxima da moralidade - uno justamente como todos, como é, de fato, metafisicamente, graças à unidade do princípio da realidade, que é a vontade una. ${ }^{367}$

Mas ainda assim, André não venceu a dor; pelo contrário, carregou-se do sofrimento universal, que o levou à renúncia extrema. Com seu estoicismo, ele muito se aproxima da "purificação ascética", proposta por Schopenhauer, mas sua excessiva bondade não lhe permitiu tornar-se indiferente à dor alheia.

Como visto, o mundo representado no romance organiza-se na duplicidade. Nesse espaço de representação, não existe apenas uma personagem em processo formativo, mas duas. Podemos verificar essa simetria na caracterização dos dois amigos, mas também na maneira como eles atuam no mundo. A individualidade, ponto-chave de qualquer processo formativo, no romance em estudo perde sua potência justamente porque o narrador tentou cindi-la no caráter de duas pessoas diametralmente opostas. Teobaldo tem exatamente o que falta em André, e vice-versa. A fusão idealizada pelo narrador nas páginas iniciais do romance não se cumpre nos anos subsequentes da trajetória formativa.

\footnotetext{
${ }^{366}$ AZEVEDO, Aluísio. O Coruja. São Paulo: Livraria Martins Editora, 1963, p. 347.

367 PADOVANI, Umberto e CASTAGNOLA, Luís. História da filosofia. São Paulo: Melhoramentos, 1970, p. 397.
} 
Acreditamos que o uso do grotesco na configuração de André, personagem que tem participação expressiva em um enredo lido sob a perspectiva de um romance de formação, não é gratuita. Trata-se de valioso elemento que nos permite afirmar que, se estamos diante de um romance de formação urdido fora dos parâmetros do cânone, há um propósito para que o grotesco seja a principal categoria organizadora da obra. E esse será o tema dos próximos itens.

\subsection{O grotesco para configurar uma trajetória formativa às avessas}

A obra em estudo está repleta de diacronia, ou seja, a vida das personagens é cercada por fatos históricos, que são apresentados não só na evolução temporal, mas também em retrospectiva. Como exemplos, podem-se mencionar o expediente de o narrador abrir espaço na trama para discorrer sobre o envolvimento do barão de Palmar na guerrilha liberal, ocorrida em 1842, ou a alusão à lei criada por Eusébio Queirós, inimigo político do pai de Teobaldo.

Esse procedimento de incluir referências explícitas à História, inclusive com inserção de datas, nomes e eventos políticos na ficção, tem como objetivo construir um fio narrativo perpassado por episódios ocorridos à época em que a obra foi escrita. Em certa medida, essa pode ter sido uma maneira encontrada por Aluísio Azevedo para não se afastar de todo do projeto inicial: criar um ciclo de romances em que retrataria aspectos sociais e políticos de sua época, como fizera Zola na França. Como vimos no primeiro capítulo desta dissertação. ${ }^{368}$

Contudo, a nosso ver, o que interessa de histórico no romance é o não dito. $\mathrm{Ou}$

\footnotetext{
${ }^{368}$ Sob o título geral Rougon-Macquart: Histoire d' une famille sous le second Empire, Zola escreveu uma série de vinte volumes, em que retrata a saga de uma família durante o Segundo Império. De acordo o próprio Zola, a produção da obra foi baseada em duas ideias principais: 1. O estudo da trajetória de uma família e como as questões de hereditariedade e as influências do meio determinam que filhos de um mesmo pai tenham paixões e características muito diferentes e o cruzamento dessas formas de vida. 2. Estudar o Segundo Império, logo após o golpe de Estado, e analisar a vida dessas personagens dentro desse contexto social e político. Portanto, a obra é baseada em estudos fisiológicos e sociais. "Document préparatoire, Nouvelles acquisitions francaises, manuscrit 10345, f 74 a 77”. In: GENGEMBRE, Gérard. Les Rougon-Macquart d' Émile Zola. Paris: Pocket, 2003, p. 43. Tradução nossa. Apesar de Aluísio Azevedo não ter conseguido repetir a façanha do escritor francês, seu projeto literário tem certa aproximação com o modelo estabelecido por Zola, não só no que se refere à intervenção de aspectos fisiológicos na caracterização das personagens, mas também na influência da realidade social e política em suas vidas.
} 
melhor, o que é dito pelas opções estilísticas do escritor e a maneira como as personagens vivem esses eventos históricos ou são afetados por eles. Ou seja, em que medida esses fatores afastam ou aproximam as personagens centrais de seus objetivos no que concerne ao processo formativo?

Retomando o apresentado no terceiro capítulo, a premissa fundamental do romance de formação pressupõe uma reconciliação do herói problemático com o entorno social, por meio de certa atuação na realidade, quando o processo formativo é concluído. Mas, como bem sintetiza Marcus Mazzari, no momento pós-goethiano:

O projeto utópico de auto-realização, enquanto desdobramento da totalidade individual, deixa de ser colocado, em seu lugar entra a necessidade de auto-afirmação pessoal e profissional numa sociedade sensivelmente modificada. ${ }^{369}$

Todavia, pelo visto até aqui, podemos afirmar que nem essa premissa da "autoafirmação" pode ser observada no romance em estudo. Uma vez que tanto André como Teobaldo estão longe de alcançar tal propósito. O que temos é uma apresentação caricatural das personagens centrais, baseada na duplicidade e construída com elementos do grotesco. Portanto, o uso do grotesco na construção do romance pode ter sido não apenas uma opção estética, mas também uma forma de estilizar a realidade histórico-social, onde as personagens estão inseridas.

A configuração grotesca de André, constatada tanto na sua caracterização corpórea como na animalização, é marco importante nesse sentido. Como já visto, o corpo naturalmente desajeitado do Coruja fica ainda mais desprovido de graça e grotesco com o passar do tempo, mas são as precárias condições de trabalho às quais se submete que determinam tais mudanças.

Apesar da feiura excessiva e da inabilidade para o contato social, André tem um caráter incorruptível e é boníssimo. Por isso, quando comparado aos seres do reino animal, tem uma representação híbrida. Já no apelido recebido por ele na escola, Coruja, há elementos demonstrativos dessa dualidade, na qual prevalece a dicotomia

\footnotetext{
${ }^{369}$ MAZZARI, Marcus. Romance de formação em perspectiva histórica: O tambor de lata de Günter Grass. São Paulo: Ateliê Editorial, 1999, p. 83.
} 
positivo/negativo. Se, por um lado, o apelido referia-se à falta de graça e beleza da coruja, não se pode negar que essa ave é símbolo do conhecimento racional, elemento também característico da personalidade de André. Portanto, sua caracterização antitética é feita em concordância com a representação dual da qual essa ave está investida.

No capítulo anterior, vimos que animais como o corvo e o cão também podem ser analisados dentro dessa perspectiva antagônica, pois, a depender do ponto de vista ou dos adjetivos a eles associados, ora têm cunho negativo, ora positivo.

Teobaldo, por sua vez, raramente é animalizado. A caracterização corporal grotesca só ocorre ao final do romance, quando ele entra em crise existencial. Todavia, a apresentação das suas ações nos capítulos finais do romance, que descrevem a maneira como ele absorve todas as novidades da época, o transformam, paulatinamente, em uma caricatura de suas ambições grotescamente cômicas.

A maneira como Teobaldo se comporta desde a infância na fazenda do pai, onde vê a natureza apenas como cenário pitoresco para emoldurar sua bela figura, além de beirar a caricatura, já sinaliza a impossibilidade de que ele venha a ser um fazendeiro. Por outro lado, cabe lembrar que, antes de fixar-se na Zona da Mata mineira, o pai de Teobaldo viajara pela Europa, combatera na revolução liberal e aventurara-se por Diamantina (MG) em busca de pedras preciosas. Logo, também não é um membro da tradicional aristocracia rural na acepção da palavra. Herdara a fazenda do sogro.

Pode ser que o autor tenha construído a base familiar de Teobaldo de maneira híbrida -, o pai aventureiro e a mãe filha de fazendeiro - com o propósito de justificar seu comportamento pouco afeito às coisas da terra. $\mathrm{O}$ que estaria de acordo com as premissas deterministas do Naturalismo. Cabe assinalar ainda que o barão de Palmar sequer aventa a possibilidade de retê-lo na fazenda. Bem diferente do pai de Wilhelm Meister, que insiste para que o filho assuma os negócios da família.

O contraste estabelecido na construção binária André/Teobaldo, calcada na dicotomia bondade/vaidade, também é marca preponderante na construção da narrativa. A trajetória dos amigos, tão carregada por sentimentos aparentemente antagônicos, acaba por dar forma caricatural à composição das personagens. 
A duplicação também é ferramenta usada para denunciar aspectos da realidade social, que permitiam a ascensão política de pessoas inescrupulosas como Teobaldo e a total impossibilidade de crescimento social de indivíduos das classes desprestigiadas econômica e socialmente, caso de André. No decorrer do romance, ainda que o narrador se esforce para demonstrar que os desvios de caráter de Teobaldo sejam decorrentes de sua hereditariedade e formação inadequada, fica evidente que esse narrador não disfarça sua ambivalência em relação a essa personagem, ou, melhor dizendo, à classe social que ele representa.

Por sua vez, a firmeza de caráter de André, como sua boa índole, é mantida inabalável até o final do romance. Ainda que tenha passado por privações e humilhações de toda ordem, o Coruja não se dobra diante das dificuldades.

Em síntese, a dicotomia bondade/vaidade, sublime/grotesco, feio/bonito, perseverança/volatilidade é evidente em demasia no decorrer da trama, e a caracterização das personagens centrais dentro desses paradigmas de maneira tão exagerada beira à caricatura. A obsessão de André pela bondade, em oposição à excessiva vaidade de Teobaldo, por exemplo, torna-se uma ideia fixa. André não realiza seus sonhos porque invariavelmente se sacrifica pelas pessoas e torna-se um homem amargo; Teobaldo acaba vitimado pela excessiva vaidade, que, se o levou à consagração pública, afastou-o das pessoas que o amaram.

Nesse caso, poderíamos dizer que essa transformação das personagens em caricaturas tem intenção grotesco-crítica. Ao sublinhar até ao exagero determinadas características da dupla, o narrador apresenta não só o que incomoda nas personagens, mas na sociedade onde elas atuam como indivíduos.

As palavras de Anatol Rosenfeld, retiradas de artigo em que analisa o sistema romântico de Schopenhauer, ilustra bem esse jogo entre essência e aparência:

A ordem é apenas aparente, no fundo reina o caos. Reais, verdadeiros são as ruínas e os esgares atrozes. Agitamo-nos num mundo de aparências, de máscaras, num mundo que é representação. No fundo - e na tendência de desmascarar o homem, Schopenhauer precede Marx, Freud e Nietzsche - no fundo somos bonecos, estrebuchando, 
com trejeitos grotescos, nas cordas manipuladas pela vontade cega e inconsciente; palhaços a se equilibrarem, aos tropeços, no circo do ser absurdo. Na falência de todos os sentidos e valores, resta só um sentido: o salto mortal para o Nada. ${ }^{370}$

\subsection{O grotesco crítico no romance $O$ Coruja}

No item inicial deste capítulo, discorremos sobre a construção das personagens centrais do romance, tendo como referência principal o díptico André/Teobaldo, e no anterior retomamos a caracterização grotesca na definição das personagens centrais do romance na perspectiva do processo formativo. Todavia, não foi por acaso que deixamos para o fechamento deste derradeiro capítulo questão fundamental sobre o grotesco: sua função crítica. A esse respeito pondera Kayser:

Neste caso, o grotesco dá margem a um discernimento formativo do objeto visado. Ou seja, não propicia apenas uma privada percepção sensorial do fenômeno, mas principalmente o desvelamento público e reeducativo do que nele se tenta ocultar. É, assim, um recurso estético para desmascarar convenções e ideais, ora rebaixando, ora expondo de modo risível ou tragicômico os mecanismo do poder abusivo. ${ }^{371}$

Já foi apontado por nós que $O$ Coruja pode ser incluído no que Bakhtin chama de romance cíclico, narrativa na qual acompanhamos a trajetória das personagens da infância à maturidade. Mas ao final desse caminho, espera-se que o idealismo juvenil dê lugar a uma posição madura e prática diante da vida. No caso de André, esse ciclo se realiza, ainda que parcialmente, mas não é o que ocorre com Teobaldo.

Nos primeiros capítulos do romance, há elementos do que o teórico russo chama de romance didático-pedagógico, não apenas pela vivência das personagens no colégio interno, mas também pelas experiências que transcorrem na fazenda do barão de Palmar. Ali são bem observáveis as diferenças no processo formativo das duas personagens. Teobaldo perde-se em devaneios românticos, enquanto André dedica-se ao conhecimento de tudo que está à sua volta. Já que, para ele, todas as experiências são

\footnotetext{
${ }^{370}$ ROSENFELD, Anatol. “A visão grotesca”. In: Texto e contexto I. São Paulo: Perspectiva, 2006, p. 66.

${ }^{371}$ KAYSER, Wolfgang. O grotesco. São Paulo: Perspectiva, 2003, p. 61.
} 
passíveis de aprendizado prático e oportunidade de crescimento.

Nas duas primeiras partes do romance, as personagens não passam por grandes mudanças. André continua com sua ideia fixa no princípio da bondade e Teobaldo torna-se cada vez mais vaidoso. Os fatos que envolvem o cotidiano dos amigos determinam o conteúdo do enredo e as mudanças sofridas ao longo da narrativa.

Contudo, na terceira parte do romance, as mudanças pelas quais passam os amigos ganham outro estofo. Ainda que prevaleçam os traços de bondade e vaidade, fatos políticos e sociais do entorno em transformação começam a interferir na vida deles. Por exemplo, em uma sociedade em transformação, Teobaldo é estimulado a sorver de todos os saberes transitórios. As aspirações da juventude não fazem mais nenhum sentido:

Entendia um pouco de tudo; sabia tirar retratos fotográficos, jogar todos os jogos de cartas e mais os de exercício, contando a esgrima, o tiro ao alvo, a pela, a bengala, o bilboquê; e cada novidade que surgia, fazendo impressão no público, encontrava nele o maior e também o menos constante entusiasta. ${ }^{372}$

Ao meter-se com a política, o filho do barão torna-se um conservador, mantendo posição bastante ambígua: "capaz de dar a última gota do seu sangue pelo monarca e também pela constituição do império, mas disposto a devorá-los a ambos no dia em que semelhante coisa fosse necessária para a felicidade do povo". ${ }^{373}$ Ou seja, é comprometedora sua postura política, associada à falta de firmeza de seu caráter, em momento crucial da história do país, a passagem da Monarquia para a República.

Diante da ameaça da dissolução das Câmaras, ${ }^{374}$ o imperador organiza um novo gabinete conservador no qual Teobaldo é indicado para assumir a pasta da Agricultura, Comércio e Obras Públicas como ministro.

\footnotetext{
${ }^{372}$ AZEVEDO, Aluísio. O Coruja. São Paulo: Livraria Martins Editora, 1963, p. 249.

373 Idem, p. 318.

${ }^{374}$ Sobre essa prática de dissolução da Câmara, recorrente no Segundo Império, vale citar observação de Raymundo Faoro: "A Câmara dava vibração ao regime, era sua parte popular, popular tendo-se em conta a tênue parcela que se ocupava de política. Réplica da Câmara dos Comuns conquistou, a par de suas funções legislativas, o lugar central da atenção pública, mercê dos poderes de desfazer gabinetes, ao preço de sua dissolução. De 1840 a 1889 passaram pelo governo 36 gabinetes, com duração média de 1,3 anos. 27 foram derrubados pela Câmara e foi esta nove vezes dissolvida pelo Imperador". FAORO, Raymundo. Machado de Assis: a pirâmide e o trapézio. São Paulo: Companhia Editora Nacional, 1974, p. 97.
} 
No primeiro capítulo deste estudo, discorremos sobre a militância política antimonarquista de Aluísio Azevedo, que pode ser confirmada tanto em seus romances como nas charges. Portanto, não é por acaso que n' O Coruja, D. Pedro II entrega em mãos tão despreparadas, como as de Teobaldo, uma importante pasta do ministério. $\mathrm{O}$ romancista, talvez com intenção crítica, coloca sua personagem em situação comum à época, como bem mostra Raymundo Faoro:

O mito se converte, no exercício do governo, no poder pessoal, de acordo com a constante denúncia, sobretudo do partido liberal, depois herdado pelos republicanos. O imperador, ao qual competia o Poder Moderador da Constituição de 1824, faz os ministérios ao seu arbítrio, sem respeito à maioria parlamentar. À margem da constituição, empolgado pelo seu papel dominante na sociedade, o chefe Estado reina, governa e administra, manobra e decide. ${ }^{375}$

Como visto no capítulo anterior - quando da análise da festa de posse de Teobaldo e o quanto tem de grotesco em sua descrição -, a opinião pública a respeito do novo ministro divergia bastante. Indo de elogios que faziam dele um homem ilustríssimo, aos xingamentos daqueles que acreditam ser ele um verdadeiro pulha. Essas opiniões eram ouvidas por André, que fora prestar homenagem ao amigo. A despeito de nessas falas imperar a crítica favorável, com destaque para o grande talento, erudição, firmeza de caráter e patriotismo de Teobaldo, as intervenções do narrador e a posição de Branca desmentem isso. Esse jogo entre a opinião pública e o verdadeiro caráter da personagem também é crítica explícita, não apenas às escolhas erradas do Imperador para a composição do ministério, mas também à pouca participação da grande maioria da população nas decisões políticas.

Enquanto Teobaldo ascende politicamente, André, com inalterável confiança em seu esforço, assume um estabelecimento de ensino quando da morte do diretor, prometendo mantê-lo sem quebra dos créditos até ali conquistados. Malgrado seus esforços, não consegue pagar as dívidas, porque resgata os títulos do amigo.

A situação social de André e Teobaldo os diferencia e, em certa medida,

375 FAORO, Raymundo. Machado de Assis: a pirâmide e o trapézio. São Paulo: Companhia Editora Nacional, 1974, p. 98. 
contribui para a definição de suas personalidades. O filho do barão de Palmar paulatinamente torna-se um medalhão e a situação de favoritismo entre os dois não é unilateral, mas ambivalente. Nessa relação, o mais beneficiado acaba sendo Teobaldo e essa exploração se dá não apenas do ponto de vista monetário, mas também intelectual.

Por vinte anos, André tinha uma segunda ideia fixa dominante - a primeira, como já vimos, era a bondade -, escrever a História do Brasil: "obra esta a que ele se escravizara desde os seus vinte anos e da qual nunca se distraíra investigando sempre, inalteravelmente, com a calma e paciência de um sábio velho que se dedica ao trabalho só pelo prazer de trabalhar, sem a menor preocupação de elogio ou glória". 376

Cabe assinalar ainda que André era um homem livre. No entanto, não é por acaso que o narrador usa o verbo escravizar para se referir à dedicação visceral do Coruja à escrita dessa obra interminável. É como se, ao usar esse verbo, o narrador já deixasse indicada a usurpação intelectual que se dará um pouco adiante.

Nos capítulos finais do romance, acompanhamos a maneira inescrupulosa como Teobaldo se apropria das notas escritas pelo amigo, publicando-as sob pseudônimo, não sem antes imprimir nelas certa "forma literária":

As conscienciosas notas de André, floreadas pelas lantejoulas da retórica do outro, converteram-se no objeto da curiosidade pública.

Foi um verdadeiro sucesso; o jornal que as publicou viu a sua tiragem aumentada e os artigos, uma vez colecionados em volume, deram várias edições. Daí nasceu o prestígio de Teobaldo entre os homens públicos do seu tempo, que desde então começaram a respeitá-lo, se bem que o habilidoso jamais declarasse positivamente ser o autor dos célebres artigos. ${ }^{377}$

A linguagem pragmática usada por André é substituída por outra, floreada e retórica. Ou seja, os dados para construir a História do Brasil, coligidos pelo árduo trabalho intelectual de André, foram modificados pelas mãos aristocráticas de Teobaldo, que imprimiram neles os floreios necessários para que fossem aceitos pela opinião pública.

\footnotetext{
${ }^{376}$ AZEVEDO, Aluísio. O Coruja. São Paulo: Livraria Martins Editora, 1963, p. 289.

${ }^{377}$ Idem, p. 291.
} 
Diante do olhar sempre indignado de Branca, Teobaldo jamais assumirá publicamente a autoria dos textos, mas, graças à maneira pouco clara como fala sobre o assunto quando perguntado a respeito, acaba sendo considerado o autor das publicações. André tampouco o desmente, a despeito das insistências de Branca nesse sentido.

O capital econômico de Teobaldo foi solapado em várias situações, mas o capital simbólico de que é investido, graças à formação que tivera, como sua maneira aristocrática de se portar socialmente, contribuíram para sua ascensão política e social. Contudo, a coroação disso vem justamente com a publicação desses artigos inspirados nas notas de André.

No ensaio "As ideias fora do lugar", Roberto Schwarz declara que, cada um a sua maneira, os escritores brasileiros do século XIX deixaram refletir em suas obras o hábito do favor como uma mediação quase universal, baseando nele sua interpretação do Brasil. Isso, em certa medida, criava um acordo tácito entre as partes:

\begin{abstract}
No momento da prestação e da contraprestação - particularmente o instante-chave do reconhecimento recíproco - a nenhuma das partes interessa denunciar a outra, tendo embora a todo instante os elementos necessários para fazê-lo. Esta cumplicidade sempre renovada tem continuidades sociais mais profundas, que lhe dão peso de classe: no contexto brasileiro, o favor assegurava às duas partes, em especial à mais fraca, de que nenhuma era escrava. ${ }^{378}$
\end{abstract}

Essa situação paradoxal, tão bem expressa por Schwarz, talvez explique por que Teobaldo se apropria com certa naturalidade do trabalho intelectual de André; homem livre, pertencente a uma classe social economicamente desfavorecida, que, desde a infância, estabelecera com o amigo uma relação pautada na subserviência.

Branca, que já perdera todas as ilusões com aquele casamento, percebe a derrocada moral do marido e se afasta cada vez mais dele. Mas, ao vê-lo quase vender seus favores de ministro a especuladores ingleses, fala claramente tudo o que pensa a respeito de Teobaldo, fazendo-o cair em profunda reflexão:

\footnotetext{
${ }^{378}$ SCHWARZ, Roberto. "As ideias fora do lugar". In: Ao vencedor as batatas. São Paulo: Duas
} Cidades, 2008, p. 11. 
Aos quarenta e tantos anos havia já percorrido a enorme gama das classes sociais e experimentado, uma por uma, toda a impressão capaz de fazer vibrar o coração humano. Desde os primeiros tempos de colégio até aquela elevada posição a que chegara, sua vida fora uma série de conquista fáceis, uma interminável cadeia de bons acasos. ${ }^{379}$

Ao entrar na vida pública, a maneira como Teobaldo assume diferentes posições, de acordo com as várias ideias que assimila para acompanhar o que estava na moda seja no âmbito político, literário, científico ou social -, vai dando contornos cada vez mais caricatos à sua imagem. Mas as seguintes palavras de Raymundo Faoro, a respeito da posição dos ministros, demonstram que o próprio posto ministerial era de fachada e muito tinha de caricato:

O poder dos ministros era, na sua maior parte, fictício, tortuoso, longo, complicado, que se estendia até S. Cristóvão, passando pelo Senado, pelo Conselho de Estado e pelos partidos. O poder - ferido de dois lados: a falta de representatividade e o desfibramento da diluição - o poder encarnado no ministro, transformava o homem em caricatura, cujos traços desfigurariam a capacidade de mandar, ordenar, fazer e desfazer. Sem a vocação de dominar o destino dos outros e de dobrar os homens, convertendo-os em súditos, o poder é apenas frustração. [...].

O ministro era apenas o fardão, com os bordados de mentira e a espada inerme. ${ }^{380}$

Então, podemos dizer que Teobaldo era uma caricatura da caricatura, em um jogo político de cartas marcadas, em que o grotesco foi, mais uma vez, explicitamente usado com função crítica.

\footnotetext{
${ }^{379}$ AZEVEDO, Aluísio. O Coruja. São Paulo: Livraria Martins Editora, 1963, p. 346.

${ }^{380}$ FAORO, Raymundo. Machado de Assis: a pirâmide e o trapézio. São Paulo: Companhia Editora Nacional, 1974, p. 99.
} 


\section{CONSIDERAÇÕES FINAIS}

Conduzimos esta trajetória analítica tendo em vista que nossa hipótese principal era a leitura d' $O$ Coruja como um romance de formação. A ampla concepção do gênero defendida por Bakhtin, em certa medida, contribuiu para a possibilidade de alinharmos esse romance brasileiro com a tradição do Bildungsroman. Mas procuramos também dialogar com o modelo goethiano. Por isso, é a partir da saga de Wilhelm Meister que gostaríamos de desenvolver essas considerações finais.

Sabemos que Os anos de aprendizagem de Wilhelm Meister originou-se de um discurso historicamente localizado. Ou seja, o conceito de formação ali ensejado estava associado a um pressuposto típico da classe média alemã no final do século XVIII. Como bem pontua Wilma Patricia Mass:

Os anos de aprendizagem de Wilhelm Meister sob o termo genérico "romance de formação" reflete esse momento histórico particular, quando a preocupação burguesa com o (auto-) aperfeiçoamento encontrava-se manifesta tanto no discurso teórico quanto nas reformas que então se ensejavam, nomeadamente no âmbito da educação e instrução. ${ }^{381}$

Todavia, Marcus Vinicius Mazzari vai mais além, ao constatar que em "um romance de formação nos moldes goethianos, o impulso individualista para o aperfeiçoamento das potencialidades pessoais necessariamente vem sempre antes do elemento da socialização, da integração do indivíduo na ordem de seu tempo". ${ }^{382}$

Realmente, as bases pedagógicas, instituídas pelos membros da Sociedade da Torre preconizavam que as qualidades individuais e os talentos inatos ao indivíduo deveriam ser considerados durante o processo formativo. Mais que isso, esses talentos, uma vez desenvolvidos, teriam que ser, de alguma forma, compartilhados com o social. Isso quer dizer que, no romance goethiano, o conceito de formação percorre um caminho que vai do sentido pedagógico-iluminista - tendo como paradigma a formação

\footnotetext{
${ }^{381}$ MASS, Wilma Patricia. O cânone mínimo: o Bildungsroman na história da literatura. São Paulo: Editora da Unesp, 1999, p. 34.

${ }^{382}$ MAZZARI, Marcus Vinicius. Labirintos da aprendizagem. São Paulo: Editora 34, p. 109.
} 
universal - ao Bildung idealizado por uma sociedade de classes, onde já se antevia a necessidade da especialização.

Em Os anos de peregrinação de Wilhelm Meister, escrito por Goethe trinta anos depois, encontramos seu protagonista exercendo uma atividade prática como médico. Isso revela como o ideal de formação filosófico-humanista, apresentado no primeiro romance, é modificado para acompanhar uma transformação histórica. Como explica Wilma Patricia Mass:

$$
\begin{aligned}
& \text { [...] em Os anos de peregrinação, o projeto de formação } \\
& \text { humanístico-filosófica dá lugar a uma concepção utilitarista, } \\
& \text { sintonizada com as vivências da técnica e do acúmulo de capital. [...] } \\
& \text { O binômio formação especialização/inserção na sociedade é, } \\
& \text { portanto, determinante em Os anos de peregrinação. }{ }^{383}
\end{aligned}
$$

Essa necessidade de renunciar à formação ampla em prol da específica já está indicada no final de Os anos de aprendizagem, quando o protagonista se conscientiza da necessidade de limitar seus anseios formativos, até então focados nas aspirações individuais. Vale dizer que, antes dessa tomada de decisão, Meister está prestes a correr mundo novamente, agora levando consigo o filho Felix. Mas as condições impostas pelos membros da Torre, que determinam que ele acompanhe um marquês italiano em uma viagem como secretário, é aceita com a seguinte afirmação: “- Entrego-me totalmente a meus amigos e à sua orientação - disse Wilhelm -; é inútil empenhar-se neste mundo em agir segundo a própria vontade. Tenho de abandonar o que desejei reter, é um benefício imerecido se que impõe a mim." ${ }^{384}$

Portanto, na parte final do romance, temos um indivíduo, em certa medida, conciliado com seu processo formativo, que vai das buscas intempestivas da juventude à necessidade de inserir-se no contexto social. Como bem sintetiza Lukács:

A ideia educativa do Wilhelm Meister é a descoberta dos métodos com a ajuda dos quais se despertam essas forças adormecidas em cada indivíduo, que se preparam para a atividade fecunda, o

\footnotetext{
${ }^{383}$ MASS, Wilma Patricia. O cânone mínimo: o Bildungsroman na história da literatura. São Paulo: Editora da Unesp, 1999, p. 184-5

${ }^{384}$ GOETHE, Johann Wolfgang von. Os anos de aprendizado de Wilhelm Meister. São Paulo: Editora 34, 2009 , p. 475.
} 
conhecimento da realidade, o conflito com a realidade, que fomentam aquele desenvolvimento da personalidade. ${ }^{385}$

Ao final do romance, encontramos o protagonista não apenas harmonizado com seu percurso formativo, e as mudanças que doravante poderão ocorrer, mas também prestes a se unir a Natalie. Ainda que outras mulheres tenham participado de sua educação sentimental - como Mariane (mãe de Felix), Philine e a Condessa -, a união com Natalie é uma espécie de coroamento desse processo formativo.

Nos primeiros tempos de Meister na trupe de teatro, ele é socorrido por uma misteriosa amazona, depois de sair ferido em uma briga com salteadores. Essa encantadora jovem só reaparecerá no romance no oitavo livro, e saberemos tratar-se de Natalie, sobrinha de Abdé, um dos mentores da Sociedade da Torre. É justamente por intermédio das explicações dela que não apenas Meister, mas também o leitor, vem a saber que uma série de episódios ocorridos na narrativa, até então dados como casuais, eram, na verdade, provocados na vida de Wilhelm pelos membros da Torre. Portanto, no caso do protagonista goethiano, o ciclo se fecha, tanto do ponto de vista da formação intelectual como sentimental.

Pelo visto neste estudo, a trajetória das personagens centrais difere bastante do percurso do protagonista goethiano. Teobaldo está longe de ter a energia e autodeterminação de Meister. Como vimos, o diletantismo da personagem aluisiana não lhe permite dedicar-se à sua formação plena e tampouco se especializar na profissão que escolhe na juventude, pois não chega a concluir o curso de Medicina. Ao final da obra, Teobaldo vê sua autoimagem refletida em fragmentos de espelho, que mostram a pequenez de sua existência, e se dá conta de que nada fizera: tinha talentos que não foram desenvolvidos, foi amado por três mulheres e não amara nenhuma, contou com a dedicação de um devotado amigo que abandonou à miséria.

No entanto, apesar da dificuldade em dedicar-se a qualquer ofício, graças à sua origem aristocrática e às relações sociais, muitas vezes escusas, que estabelece com pessoas do seu meio, consegue alcançar um posto político significativo. Mas, ao final do romance, se dá conta da própria mediocridade. $\mathrm{O}$ fato de não ter construído nada a

${ }^{385}$ LUKÁCS, George. Posfácio. In: GOETHE, Johann Wolfgang von. Os anos de aprendizado de Wilhelm Meister. São Paulo: Editora 34, 2009, p. 595. 
partir de seus esforços passa a atormentá-lo, mas, além disso, constata que sua infelicidade se deve ao fato de que nunca tivera a "menor sombra de amor pelo trabalho, nem desejo de ser útil à pátria ou aos seus semelhantes, mas só à vaidade". 386

André, por sua vez, possui uma interioridade muito rica e esse íntimo nos é dado a conhecer com bastante precisão. Nos capítulos finais do romance, enquanto Teobaldo ascende na vida pública, tornando-se cada vez mais brilhante diante da sociedade, mais o Coruja mergulha em uma situação obscura e miserável.

A despeito de todos os seus esforços como intelectual, André não consegue furar o bloqueio social. É estudioso e aplicado, mas sua falta de graça e excessiva timidez o impedem de passar nos exames, embora soubesse todas as matérias. Consegue economizar para comprar uma escola, onde aplicaria suas ideias inovadoras sobre educação, contudo a relação com Teobaldo, para com quem se sente um eterno devedor, o impossibilita de realizar seus planos. No seu caso, a educação sentimental tampouco se realiza, já que não consegue desposar Inezinha. Única possibilidade afetiva que a vida lhe acenara. Portanto, no caso de André, a formação é cerceada, de um lado, por sua própria insegurança e baixa autoestima; por outro, pelo entorno social pouco favorável.

Ao ler as duas primeiras partes do romance, até podemos supor que a solidariedade estabelecida nos anos iniciais de convivência entre os amigos se estenderá nos posteriores, de maneira a contribuir para que o processo formativo de ambos seja bem-sucedido, mas já mostramos que essa possibilidade é desfeita na última parte da obra.

Como vimos, o romance é construído tendo como base figurações do grotesco, presentes na animalização das personagens; na descrição das cenas festivas; no uso de distúrbios, como as crises nervosas, para provocar reviravolta na narrativa; mas também na construção do díptico André/Teobaldo. Com isso, tentamos mostrar que, além de o grotesco ser uma das categorias organizadoras da obra, é justamente seu uso exacerbado que contribui para a possibilidade de leitura da obra como um romance de formação "às avessas".

${ }^{386}$ AZEVEDO, Aluísio. O Coruja. São Paulo: Livraria Martins Editora, p. 260. 
Isso posto, conclui-se que o pretenso processo formativo das duas personagens se vê malogrado, tanto quando analisamos a trajetória delas como ao observarmos os aspectos formais utilizados na construção narrativa.

Temos consciência de que, diferentemente do ocorrido na literatura europeia em geral e na alemã especificamente - onde o romance de formação é pedra angular, chegando sua origem a ser confundida com a própria gênese do gênero romance -, na literatura brasileira, sobretudo do século XIX, o conceito foi pouco explorado. Por isso, não foram poucas as dificuldades enfrentadas para fundamentarmos as ideias apresentadas neste estudo. Mas esperamos ter conseguido mostrar que esse romance tão pouco estudado de Aluísio Azevedo pode ser lido como um romance de formação, em que as figurações do grotesco são usadas com explícita função crítica.

Todavia, o que continua a reverberar ao término da leitura do romance é que, embora André tenha sido sempre subserviente a Teobaldo - como também o foi em relação a outras personagens do romance -, o criterioso professor tem a árida missão de escrever a História do país. Projeto também malogrado, bem sabemos. Não porque faltasse a André competência para tanto, mas porque o processo de construção nacional, ainda incipiente, assim determinaria. Podemos então dizer, que a ambiguidade do narrador do romance "é apenas uma figura a mais do jogo calculado, a nos alertar sobre a figura social que este narrador representa". ${ }^{387}$ Como trabalhar ficcionalmente um processo de formação bem-sucedido, tanto na forma como no conteúdo, se o escritor estava diante de uma sociedade escravocrata, pseudoliberal e desgraçadamente pautada em diferenças sociais intransponíveis?

O enterro de Teobaldo, feito com honrarias e pompas, não poderia ser visto como uma alegoria? Ou seja, seu sepultamento não poderia significar o processo de agonia da própria aristocracia rural decadente, em um país onde se viam os estertores da Monarquia diante da República iminente? Se assim for, André, por sua vez, pode representar uma classe de intelectuais que bravamente tentava encontrar um lugar ao sol, em uma sociedade ainda tão marcada pelas diferenças sociais.

Indo mais além, na posição de "mosqueteiros intelectuais", papel assumido por

${ }^{387}$ CARA, Salete de Almeida. Marx, Zola e a prosa realista. Cotia: Ateliê Editorial, 2009, p. 158. 
Aluísio Azevedo e muitos de sua época, estava previsto, ainda que no plano simbólico, espaço para atuação na construção desse ideário de nação, que, como vimos no primeiro capítulo, foi malogrado. Nessa perspectiva, as dificuldades enfrentadas por André podem simbolizar os problemas vividos pelos próprios escritores e intelectuais à época.

Talvez por isso, apesar de melancólica, a última frase do romance é otimista e coloca nas mãos de intelectuais como André a importante missão de dar de comer ao povo: "E manquejando, a limpar os olhos com a manga do casaco, lá se foi, rua abaixo, perguntando a si mesmo 'Onde diabo iria, àquelas horas, arranjar dinheiro para dar de comer ao seu povo?..." 


\section{REFERÊNCIAS BIBLIOGRÁFICAS}

\section{Do autor e sobre o autor}

ABREU, Capistrano. Ensaios e estudos. 4. ${ }^{a}$ série. Rio de Janeiro: Civilização Brasileira, 1976.

AZEVEDO, Aluísio. Ficção completa. vols. I e II. Rio de Janeiro: Aguilar, 2005. O Coruja. Prefácio de Nogueira da Silva. São Paulo: Livraria Martins Editora, 1954.

- O Coruja. Rio de janeiro: F. Briguiet \& Cia Editores. [s/d].

. O Coruja. Prefácio de Raimundo de Menezes. São Paulo: Livraria Martins

Editora, 1963.

. Girândolas de amores. Introdução de Eugênio Gomes. São Paulo: Livraria Martins Editora, 1960.

Mattos, Malta ou Matta? Introdução de Plínio Doyle e Josué Montello. Rio de Janeiro: Nova Fronteira/Fundação Casa Rui Barbosa, 1985.

. Touro negro. São Paulo: Livraria Martins Editora, 1961.

Japão. São Paulo: Roswitha Kempf, 1984.

Demônios. São Paulo: Teixeira \& Irmão Editores, 1893.

BRAYNER, Sonia. A metáfora do corpo no romance naturalista: estudo sobre o cortiço. Rio de Janeiro: Livraria São José, 1973.

CANDIDO, Antonio. $O$ discurso e a cidade. São Paulo/Rio de Janeiro: Duas Cidades/Ouro sobre Azul, 2004.

COUTINHO, Afrânio; COUTINHO, Eduardo de Faria. A literatura no Brasil: era Realista, era de transição. São Paulo: Global, 1997.

CRUZ, Laura Camilo dos Santos. O naturalismo em cena: estudo da evolução da linguagem de Aluísio Azevedo em $O$ mulato sob uma perspectiva genética. São Paulo: FFLCH/ PROEX- CAPES, 2008.

DANTAS, Paulo. Aluísio Azevedo. São Paulo: Melhoramentos, [19--].

GOMES, Eugênio. Aspectos do romance brasileiro. Salvador: Progresso, 1958.

FARIA, João Roberto. Teatro de Aluísio Azevedo e Emílio Rouède. São Paulo: Martins Fontes, 2002. 
FILHO, Adonias. Introdução ao livro Touro negro. São Paulo: Livraria Martins Editora, 1961

JÚNIOR, Araripe. A obra crítica de Araripe Júnior. v. 1. Rio de Janeiro: Casa de Rui Barbosa, 1958.

MAYA, Alcides. Discurso proferido na sessão solene extraordinária do dia 21 de julho de 1914 na Academia Brasileira de Letras. Disponível em: <www.academia.org.br/abl/media/Tomo\%20I\%20-\%201897\%20a\%201919.pdf>. p. 669. Acesso em: jun. de 20121.

LEVIN, Orna Messer. Aluísio Azevedo romancista. In: Aluísio Azevedo. Ficção Completa, vols. I e II. Rio de Janeiro: Nova Aguilar, 2005.

MENEZES, Raimundo de. Introdução ao romance O Coruja, de Aluísio Azevedo. São Paulo: Livraria Martins Editora, 1963.

Aluísio Azevedo, uma vida de romance. São Paulo: Livraria Martins Editora, 1958.

MÉRIAN, Jean-Yves. Aluísio Azevedo, vida e obra (1857-1913). Rio de Janeiro: Espaço e Tempo, 1988.

MIGUEL-PEREIRA. Lúcia. História da literatura brasileira, v. XII. Rio de Janeiro: José Olympio, 1957.

MILLIET, Sérgio. Introdução ao romance O cortiço, de Aluísio Azevedo. São Paulo: Livraria Martins Editora, 1959.

MOISÉS, Massaud. História da literatura brasileira: realismo e simbolismo. São Paulo: Cultrix, 2001.

MONTELlO, Josué. Aluísio Azevedo: trechos escolhidos. Rio de Janeiro: Agir, 1969. (Coleção Nossos Clássicos)

NETO, Coelho. A conquista. Porto: Livraria Chardon, 1928.

OLIVEIRA, Franklin. Aluísio Azevedo. In: Literatura e civilização. Rio de Janeiro: Difel/MEC, 1978.

OCTAVIO, Rodrigo. Minhas memórias dos outros. Rio de Janeiro: Civilização Brasileira, 1979.

PRADO, Antonio Arnoni. Aluísio Azevedo e a crítica. In: AZEVEDO. Aluísio. Ficção completa. Rio de Janeiro: Nova Aguilar, 2005.

ROMERO, Silvio. Retrospecto literário (1888). In: História da literatura brasileira. v. 
V. Rio de Janeiro: José Olympio, 1960.

SILVA, M. Nogueira da. Prefácio da $6^{\text {a }}$ edição. In: AZEVEDO, Aluísio. O Coruja. São Paulo: Livraria Martins Editora, 1954.

SODRÉ, Nélson Werneck. O naturalismo no Brasil. Belo Horizonte: Oficina de Livros, 1992.

VERÍSSIMO, José. História da literatura brasileira: de Bento Teixeira (1601) a Machado de Assis (1908). Rio de Janeiro: Topbooks, 1998.

\section{Sobre o romance de formação}

BAKHTIN, Mikhail. O romance de educação na história do realismo. In: Estética da criação verbal. São Paulo: Martins Fontes 1992.

BOSI, Alfredo. Céu, inferno. São Paulo: Duas Cidades/Editora 34, 2003.

GOETHE, Johann Wolfgang von. Os anos de aprendizado de Wilhelm Meister. São Paulo: Editora 34, 2009.

KAYSER, Wolfgang. A estrutura do gênero. In: Análise interpretação da obra literária. São Paulo: Livraria Martins Editora, 1976.

LUCAS, Fábio. As várias faces de Raul Pompéia. Remate de Males. n. 5. Campinas: Editora da Unicamp, 1995.

LUKÁCS, Georg. A teoria do romance. Trad. de Alfredo Margarido. Lisboa: Editorial Presença, [19--].

Posfácio. In: GOETHE, Johann Wolfgang von. Os anos de aprendizado de Wilhelm Meister. São Paulo: Editora 34, 2009.

MASS, Wilma Patrícia. O cânone mínimo: o Bildungsroman na história da literatura. São Paulo: Editora da Unesp, 1999.

MAZZARI, Marcus. Romance de formação em perspectiva histórica: O tambor de lata de Günter Grass. São Paulo: Ateliê Editorial, 1999.

Labirintos da aprendizagem: pacto fáustico, romance de formação e outros ensaios de literatura comparada. São Paulo: Editora 34, 2010. 


\section{Sobre o grotesco}

BAKHTIN, Mikhail. A cultura popular na Idade Média e no Renascimento: o contexto de François Rabelais. São Paulo: Hucitec, 2010.

ECO, Umberto (Org.). História da feiura. Rio de Janeiro: Record, 2007.

FREITAS, Maria Eurides Pitombeira de. O grotesco na criação de Machado de Assis e Gregório de Matos. Rio de Janeiro: Presença, 1981.

GUINSBURG, Jacó. (Org.) . O romantismo. São Paulo: Perspectiva, 2002.

HUGO, Victor. O sublime e o grotesco. São Paulo: Perspectiva, 2007.

KAYSER, Wolfgang. O grotesco, configuração na pintura e na literatura. São Paulo: Perspectiva, 2003.

ROSENFELD, Anatol. Texto / contexto I. São Paulo: Perspectiva, 2006.

SANTAYANA, George. El sentido de la belleza. Madri: Tecnos, 2002.

SODRÉ, Muniz; PAIVA, Raquel. O império do grotesco. Rio de Janeiro: Mauad, 2002.

\section{Geral}

AUERBACH, Erich. Mimesis. São Paulo: Perspectiva, 1987.

BRAYNER, Sonia. Labirinto do espaço romanesco. Rio de Janeiro: Civilização Brasileira, 1979.

BAUDELAIRE, Charles. «O pintor da vida moderna ». In: Poesia e prosa. Rio de Janeiro: Nova Aguilar, 2006, p. 853.

CANDIDO, Antonio. Formação da literatura: Momentos decisivos. Rio de Janeiro: Ouro sobre o Azul, 2006.

CARA, Salete de Almeida. Marx, Zola e a prosa realista. Cotia: Ateliê Editorial, 2009.

CARPEAUX, Otto Maria. O livro de ouro da história da música: da Idade Média ao Século XX. Rio de Janeiro: Ediouro, 2009. A literatura alemã. São Paulo: Cultrix, 1964, p. 94-96. História da literatura ocidental. v. 1. Rio de Janeiro: Allhambra, 1978.

CHEVALIER, Jean; GHEERBRANT, Alain. Dicionário de símbolos. Rio de Janeiro: José Olympio, 1982.

CHEVREL, Yves. Poétique du Naturalisme. In: BESSIÈRE, J. (Org.). Histoire des 
poétiques. Paris: PUF, 2000.

COSTA, Emília Viotti. Da Monarquia à República: momentos decisivos. São Paulo: Editora da Unesp. 1998.

Da senzala à colônia. São Paulo: Editora da Unesp, 1996.

DEAECTO, Marisa Midori. O império dos livros. São Paulo: Edusp, 2011.

D’ INCAO, Maria Ângela. Mulher e família burguesa. In: DEL PRIORE, Mary (Org.).

História das mulheres no Brasil. São Paulo: Editora da Unesp/Contexto, 2008.

ENGEL, Magali. Psiquiatria e feminilidade. In: DEL PRIORE, Mary (Org.). História das mulheres no Brasil. São Paulo: Editora da Unesp/Contexto, 2008.

FAORO, Raymundo. Machado de Assis: a pirâmide e o trapézio. São Paulo: Companhia Editora Nacional, 1974.

FAUSTO, Boris. História concisa do Brasil. São Paulo: Edusp, 2010.

FERREIRA, da Costa Orlando. Imagem e Letra: introdução à bibliologia brasileira - a imagem gravada. São Paulo: Edusp, 1994.

FRANCO, Maria Sylvia de Carvalho Franco. Os homens livres na ordem escravocrata. São Paulo: Editora da Unesp, 1997.

GENGEMBRE, Gerard. Les rougon-Macquart d'Émile Zola, analyse de l'ouvre. Paris: Univers Poche, 2003.

GIRARD, René. A crítica do subsolo. São Paulo: Paz e Terra, 2011.

GUIMARÃES. Hélio de Seixas. Os leitores de Machado de Assis: o romance machadiano e o público de literatura no século 19. São Paulo: Nankin/Edusp, 2004.

HALLEWELL, Laurence. O livro no Brasil (Sua história). São Paulo: T.A. Queiroz/Edusp, 1885

HOLANDA, Sérgio Buarque de. Herança Rural. In: Raízes do Brasil São Paulo: Companhia das Letras, 2004.

HUGO, Victor. O corunda de Notre Dame. São Paulo: Edtora Três, [19--].

LAJOLO, Marisa; ZILBERMAN, Regina. O preço da leitura: leis e números por detrás das letras. São Paulo: Ática, 2001.

LOURO, Guacira Lopes. Mulheres na sala de aula. In: DEL PRIORE, Mary (Org.). História das mulheres no Brasil. São Paulo: Editora da Unesp/Contexto, 2008.

MEYER, Marlyse. Folhetim. São Paulo: Companhia das Letras, 2005.

OEHLER, Dolf. Terrenos vulcânicos. São Paulo: Cosac Naify, 2004. 
PADOVANI, Umberto; CASTAGNOLA, Luís. História da filosofia: São Paulo: Melhoramentos, 1970.

REUTER, Yves. Introdução à análise do romance. São Paulo: Livraria Martins Editora, 2004.

ROSENFELD, Anatol. A visão grotesca. In: Texto e contexto. São Paulo: Perspectiva, 2006.

; GUINSBURG, Jacó. Um encerramento . In: GUINSBURG, J (Org.). $O$ romantismo. São Paulo: Perspectiva, 2002.

ROSSET, Clément: O real e seu duplo. Porto Alegre: L\&PM, 1988.

SEVCENKO, Nicolau. Literatura como missão: tensões sociais e criação cultural na Primeira República. São Paulo: Companhia das Letras, 2009.

SCHOPENHAUER, Arthur. O mundo como vontade e representação. In: Schopenhauer. São Paulo: Abril, 1980. (Coleção Os Pensadores)

Sobre o fundamento da moral. Trad. Maria Lúcia Mello e Oliveira Cacciola. São Paulo: Martins Fontes, 2001.

SCHWARZ, Roberto. Ao vencedor as batatas. São Paulo: Duas Cidades/Editora 34, 2008 .

Nacional por subtração. In: Que horas são? São Paulo: Companhia das Letras, 1989.

SODRÉ, Nelson Werneck. História da imprensa no Brasil. São Paulo: Martins Fontes, 1983.

. Naturalismo no Brasil. Belo Horizonte: Oficina de Livros, 1992.

História da literatura brasileira. Rio de Janeiro: Civilização Brasileira, 1964.

TÁVORA, Franklin. Prefácio. In: O cabeleira. São Paulo: Editora Três, 1973.

WISNIK, José Miguel. Algumas questões de música e política no Brasil. In: BOSI, Alfredo (Org.). Cultura brasileira: temas e situações. São Paulo: Ática, 2006.

ZOLA, Émile. Do romance. São Paulo: Edusp, 1995. 


\section{Sobre os anexos}

Charge Visão do século XX, reproduzida em: MENEZES, Raimundo de. Aluísio Azevedo, uma vida de romance. São Paulo: Livraria Martins Editora, 1958.

Charge Romantismo e Realismo: luta aberta, reproduzida em: MÉRIAN, Jean-Yves. Aluísio Azevedo, vida e obra (1857-1913). Rio de Janeiro: Espaço e Tempo, 1988.

Charge Um sonho oriental, reproduzida em: MENEZES, Raimundo de. Aluísio Azevedo, uma vida de Romance. São Paulo: Livraria Martins Editora, 1958.

Charge publicada em O Mequetrefe, em 10/04/1877, reproduzida em: MÉRIAN, JeanYves. Aluísio Azevedo, vida e obra (1857-1913). Rio de Janeiro: Espaço e Tempo, 1988.

Autorretrato publicado em A Comédia Popular, reproduzido em: MÉRIAN, Jean-Yves. Aluísio Azevedo, vida e obra (1857-1913). Rio de Janeiro: Espaço e Tempo, 1988.

Páginas do periódico O Paiz, durante o período 2/06/1885 e 12/10/1885, extraídas de reprodução de microfilme encontrado na Biblioteca Nacional do Rio de Janeiro. 
ANEXOS 


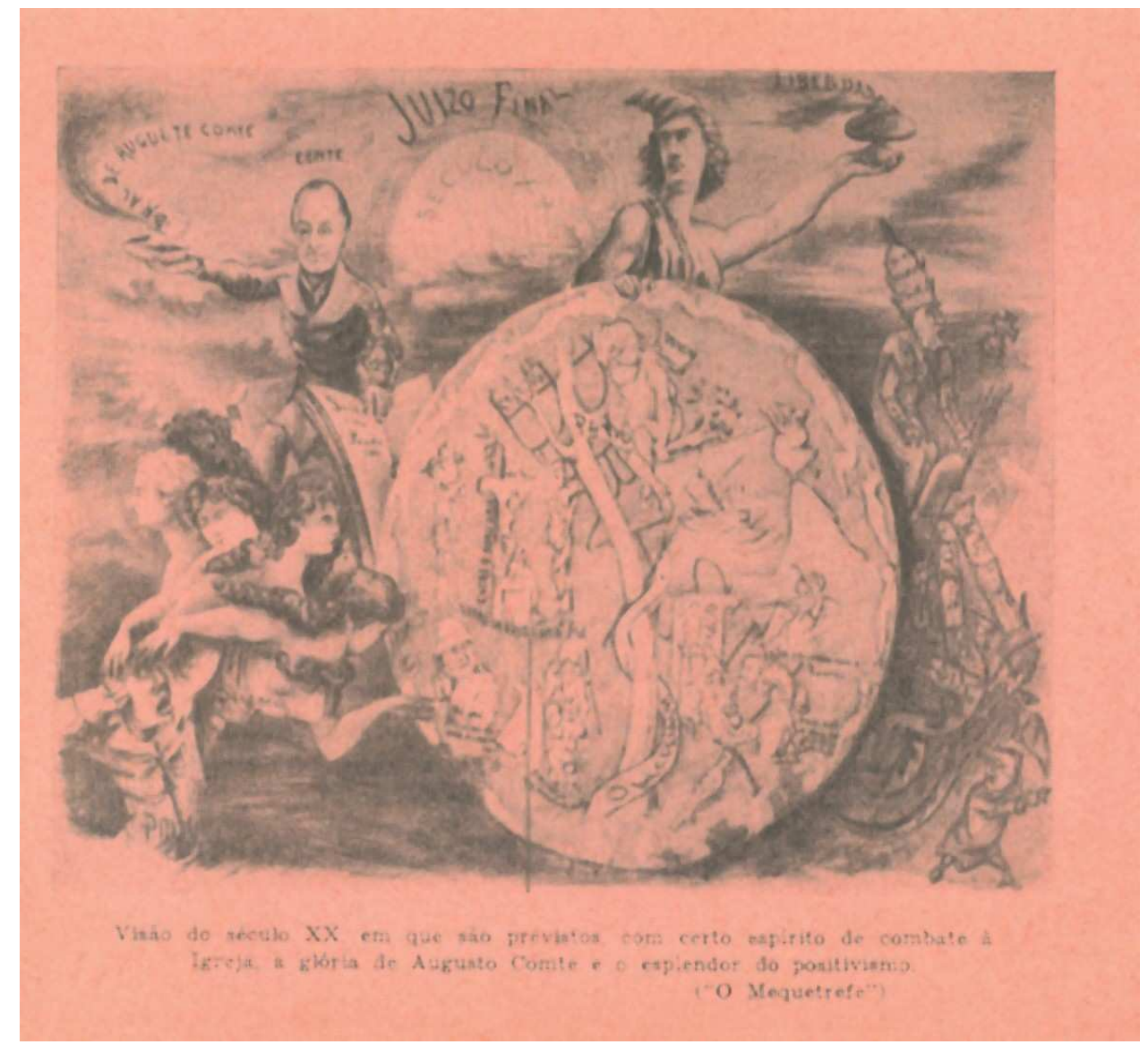

Em algumas charges é explícita a influência do Positivismo na formação de Aluísio Azevedo. Como é o caso da intitulada Visão do século XX. Uma espécie de alegoria do Juízo Final, publicada em $O$ Mequetrefe, em que se vê Augusto Comte combatendo membros do clero. 


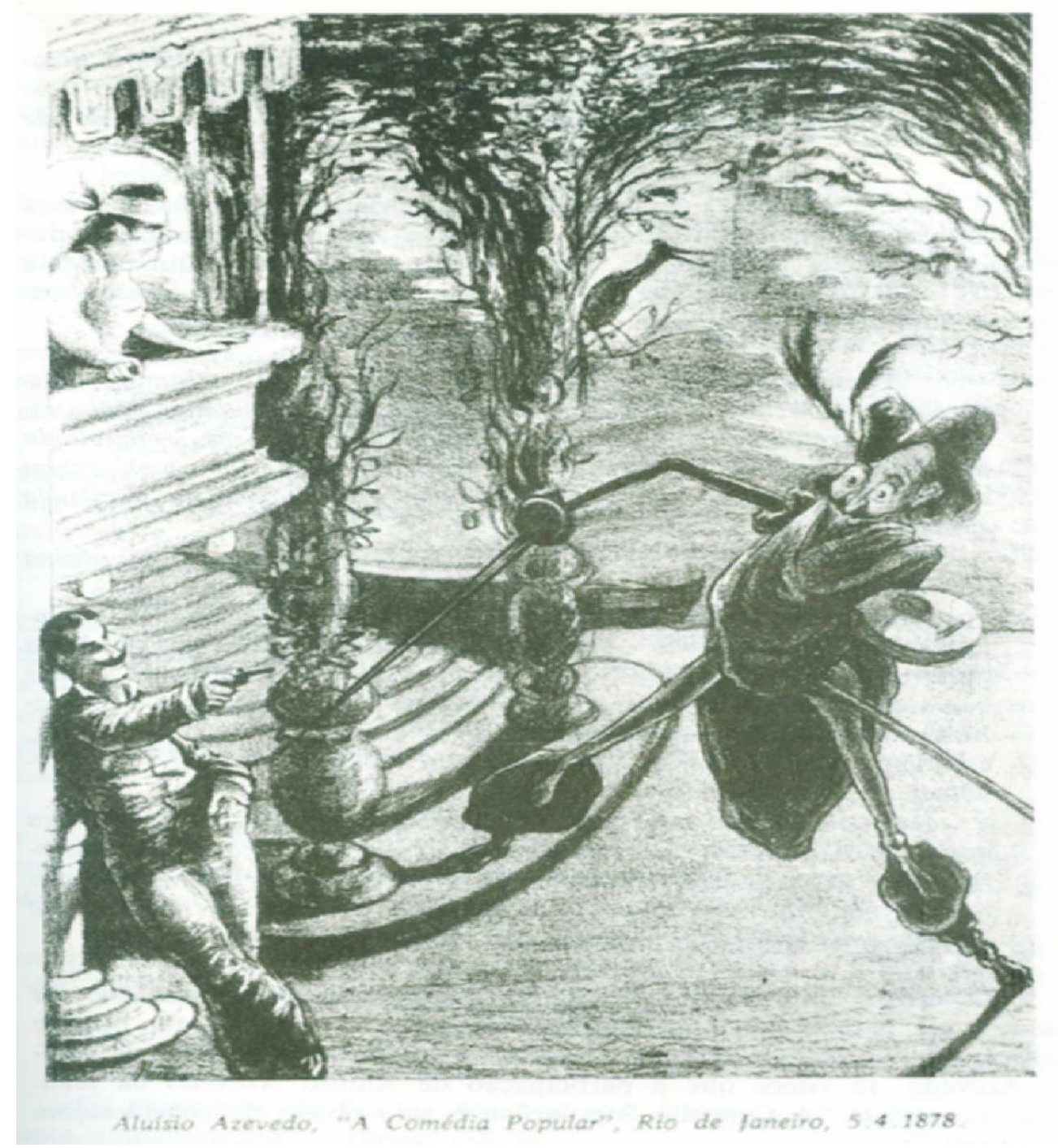

Charge Romantismo e Realismo: luta aberta, publicada em A Comédia Popular. Rio de Janeiro, 5/04/1878. Na imagem, vê-se um balcão, de onde Elvira, de olhos vendados, alegoria da poesia, assiste ao embate entre D. Juan, representante do Romantismo, que usa uma espada, e Basílio, símbolo da estética Realista, de revólver em punho. 


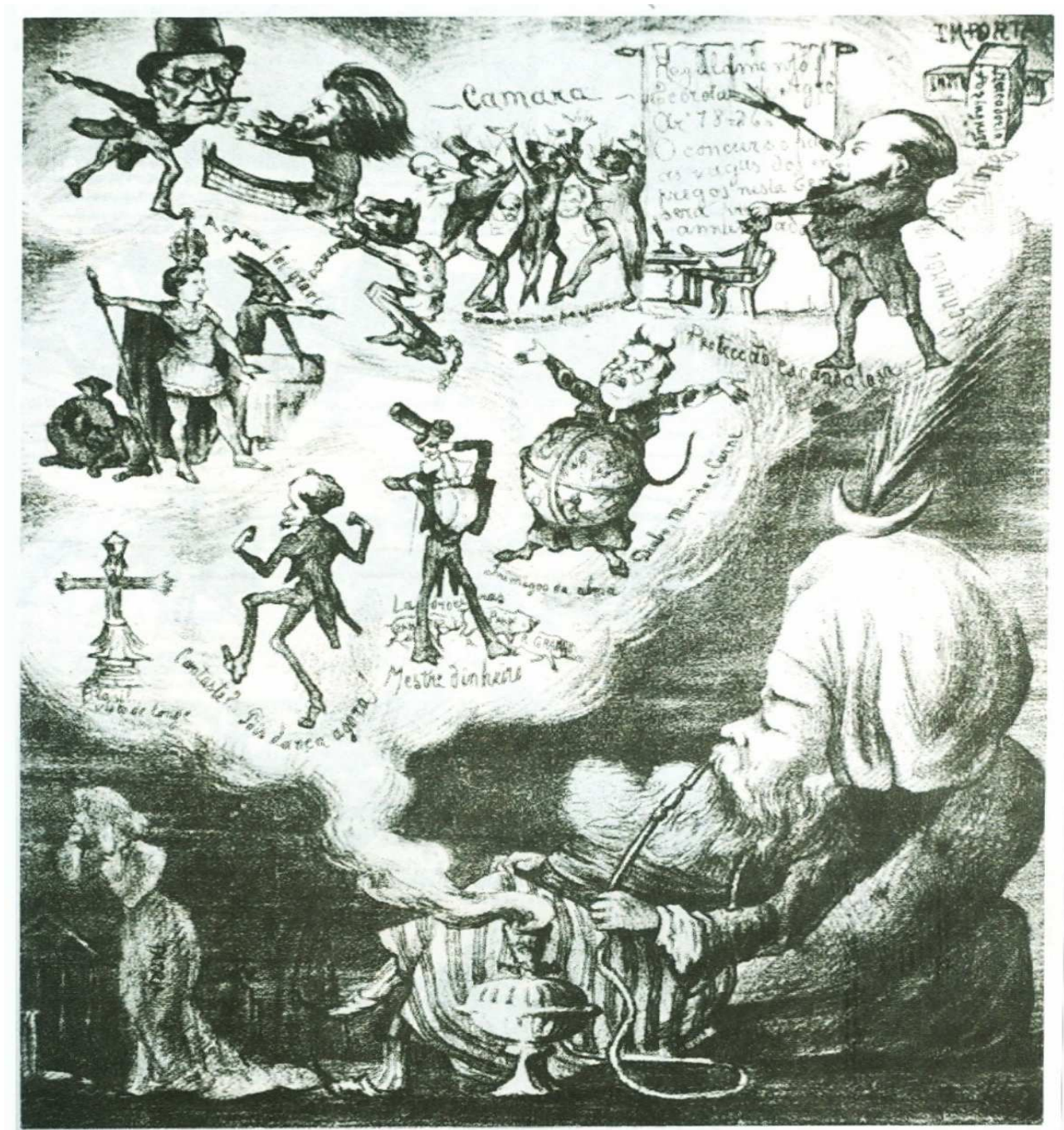

Afulsio Azevedo, "O Mequetrefe". n" 94, Rio de faneiro, $19.3,1877$

Charge publicada em O Mequetrefe, em 19/03/1877, intitulada Um sonho oriental. O imperador é representado no primeiro plano fumando um narguilé. Da fumaça expelida saem imagens da vida política e econômica do Brasil (anarquia na Câmara, escândalos financeiros, o uso indevido do poder pela Igreja e a dependência das relações exteriores). Representada à esquerda, em tamanho menor, há uma mulher aos prantos, provavelmente simbolizando a Pátria. 


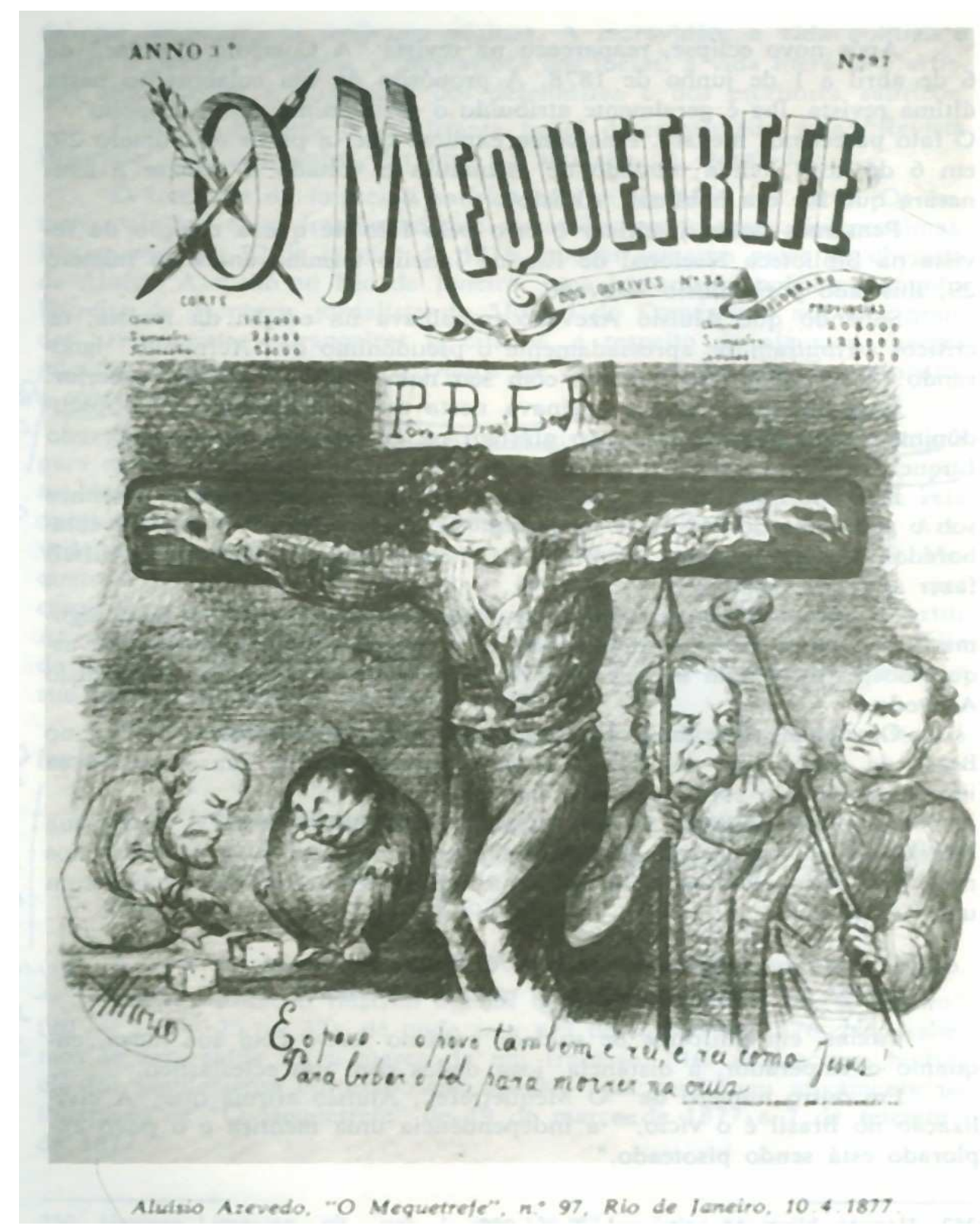

Charge publicada em O Mequetrefe, em 10/04/1877. Nela, vê-se o general Duque de Caxias, golpeando um representante do povo crucificado com uma lança, enquanto o imperador joga dados com um clérigo ao fundo. Abaixo da imagem lê-se: "E o povo... o povo também é rei como Jesus! Para beber o fel para morrer na cruz!" 


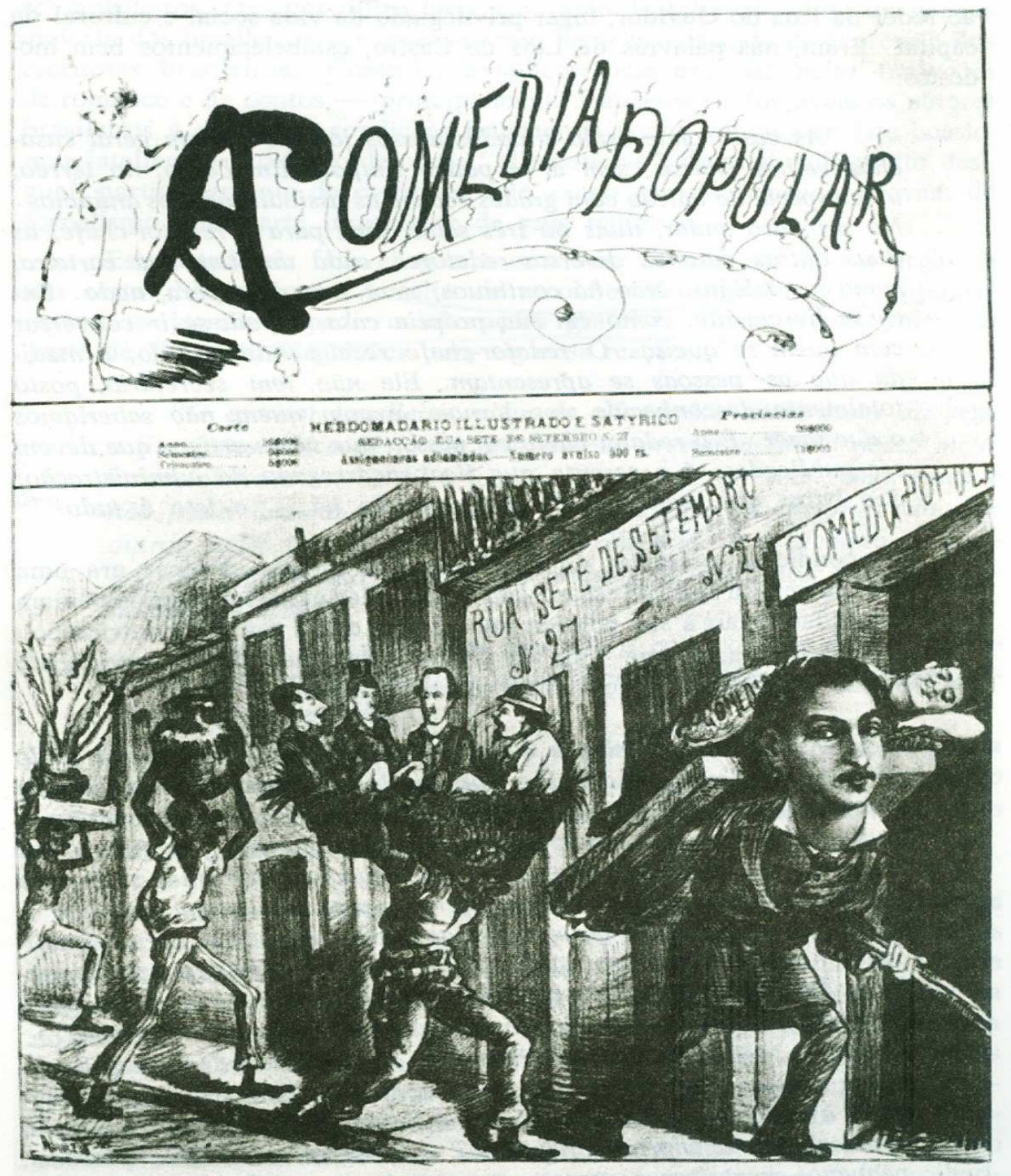

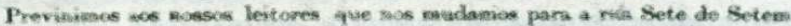

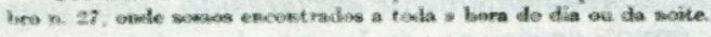

Autorretrato, publicado em 15/04/1878, quando da mudança de endereço da revista A Comédia Popular. Na legenda lê-se: "Prevenimos aos nossos leitores que nos mudamos para a rua Sete de Setembro, n. 27, onde somos encontrados toda hora do dia e da noite." 
Algumas páginas do jornal o Paiz, onde foi publicado o folhetim $O$ Coruja, de 2/06/1885 a 12/10/1885.

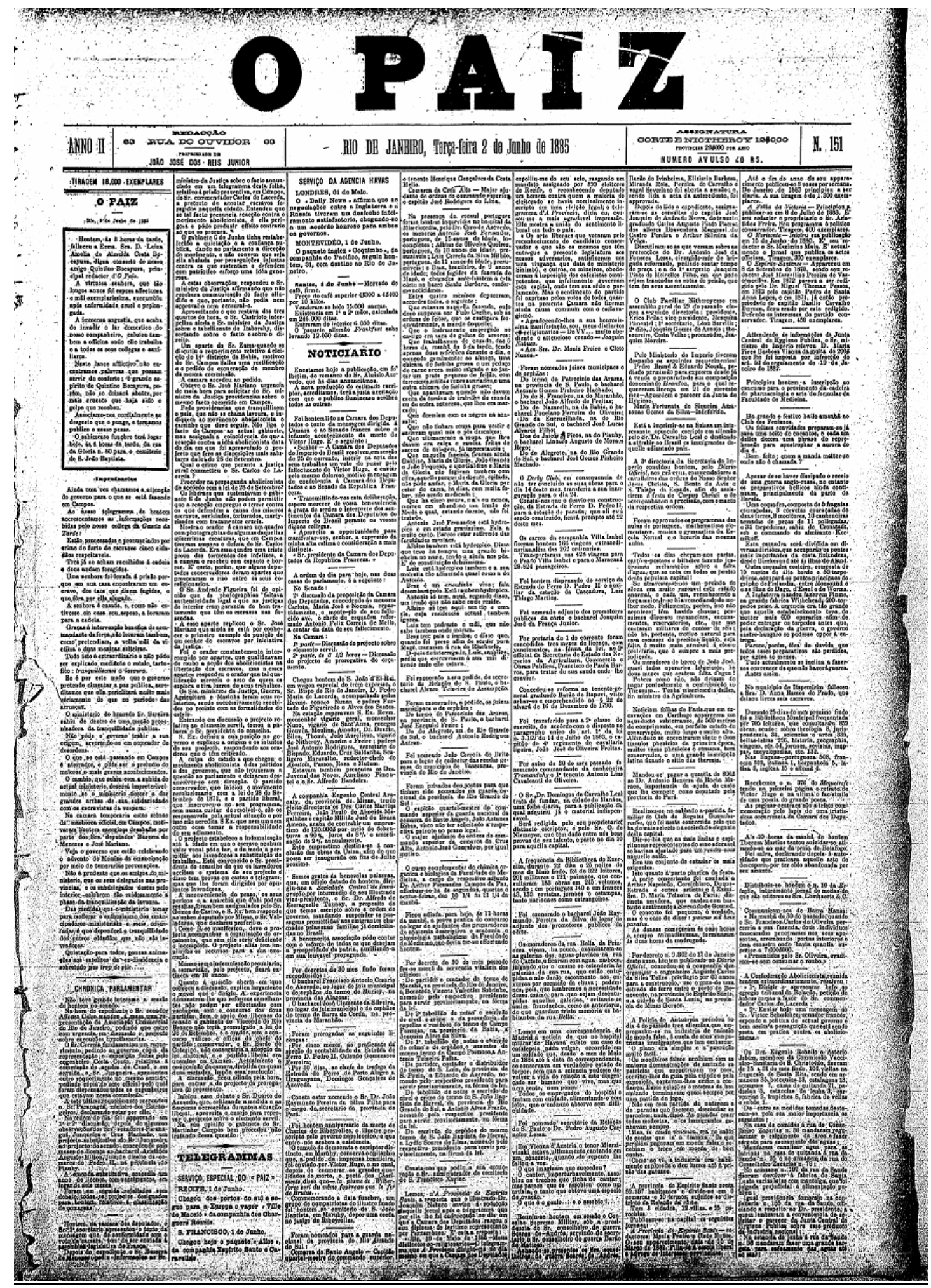




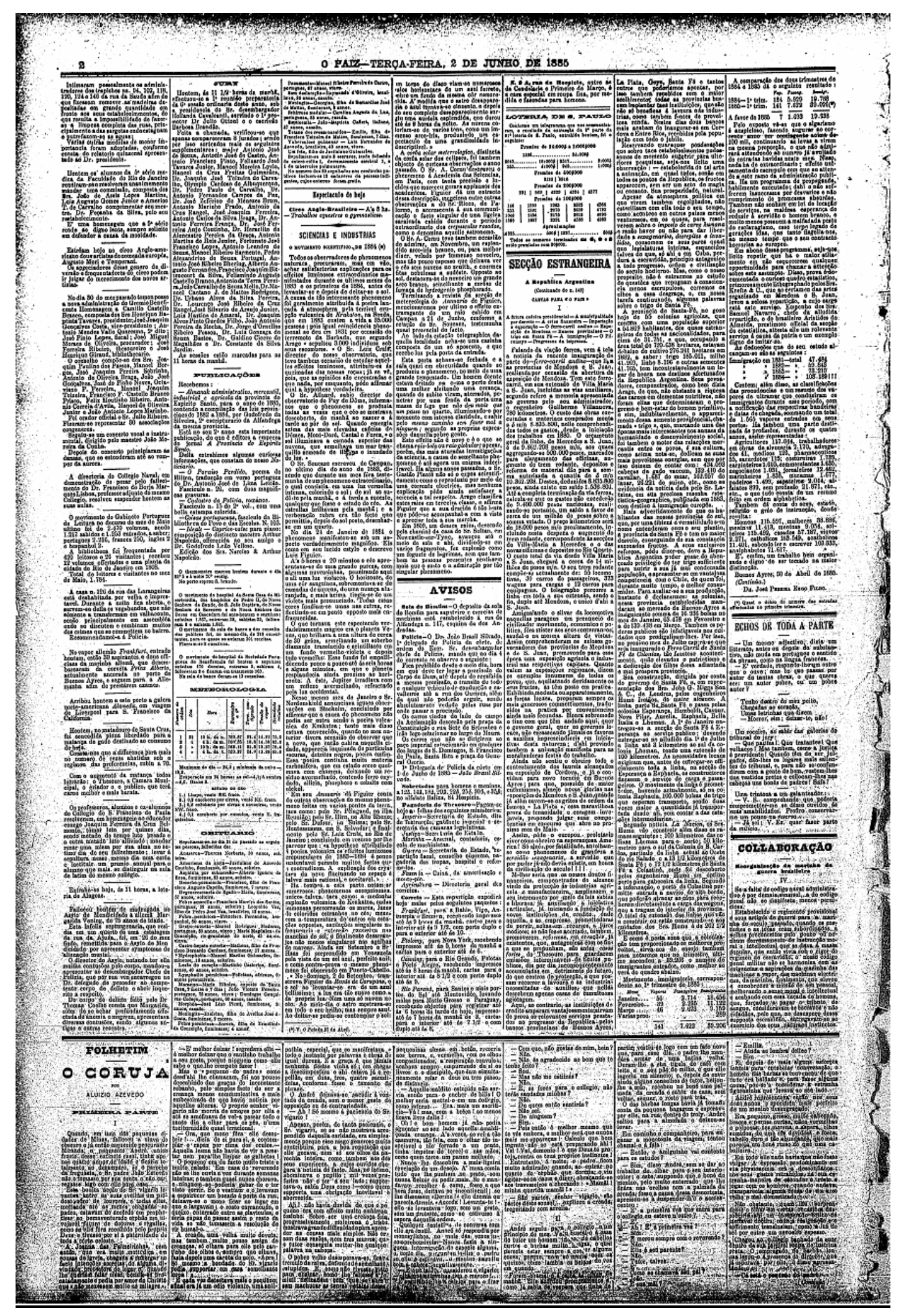




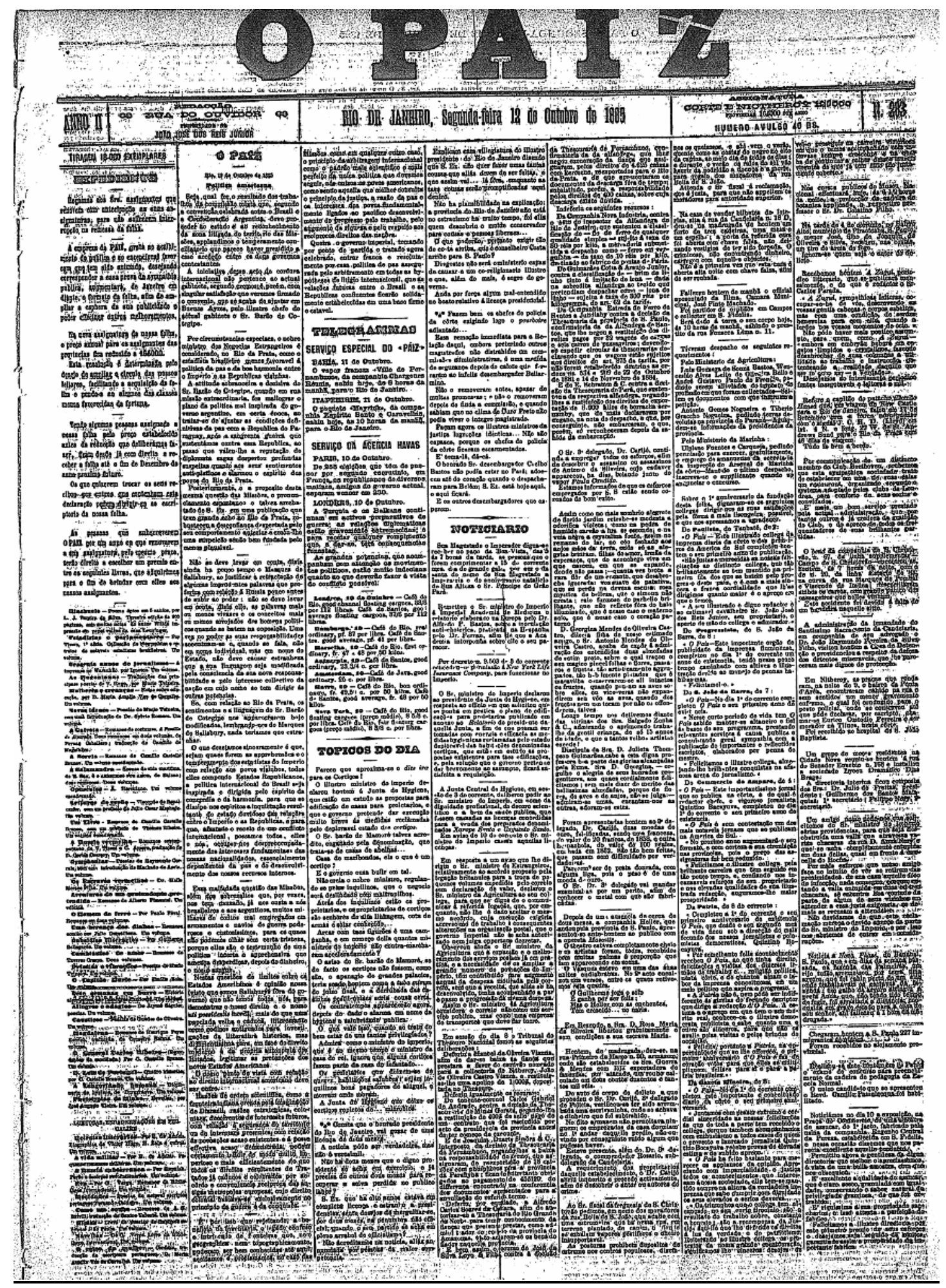




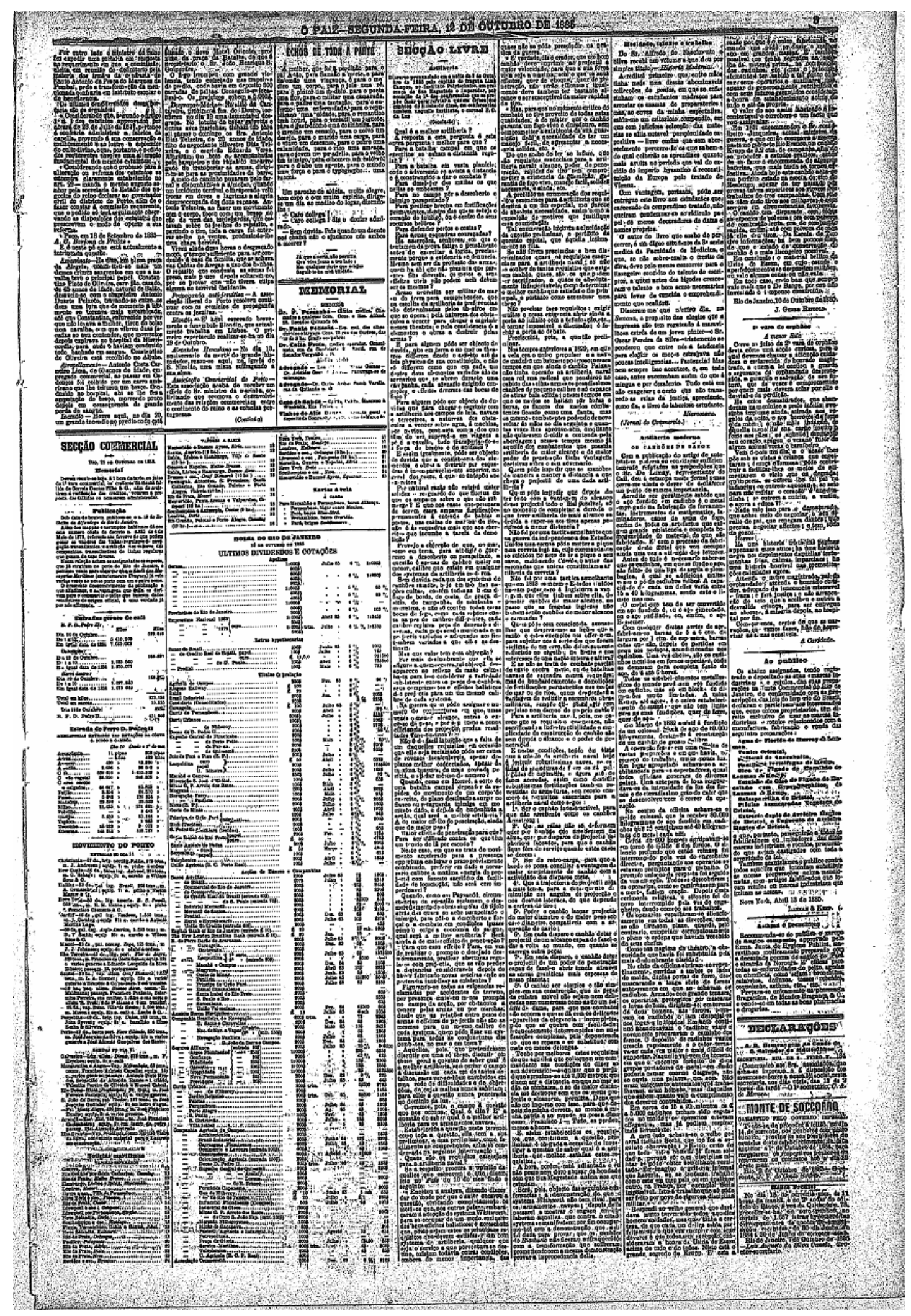




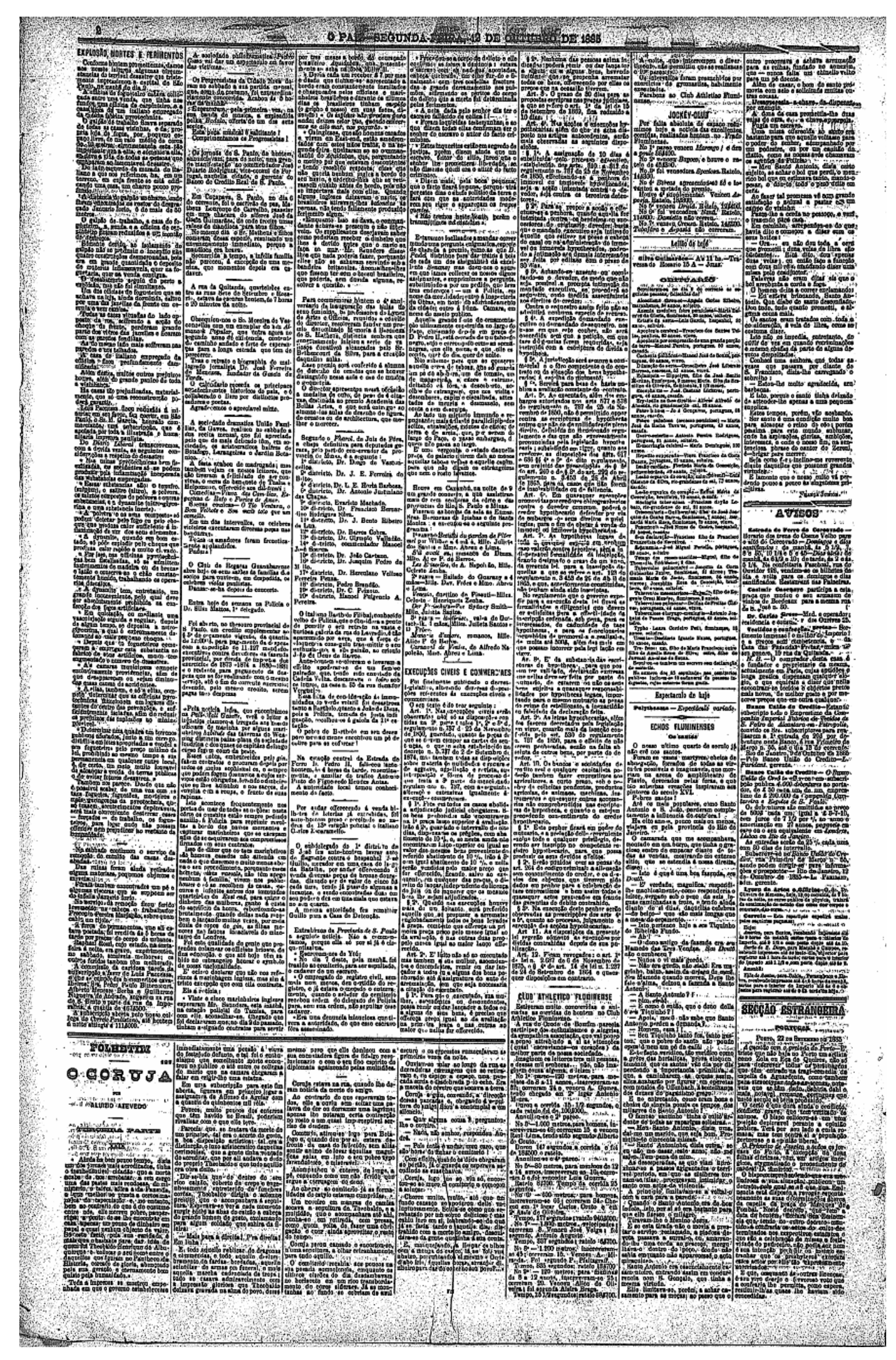




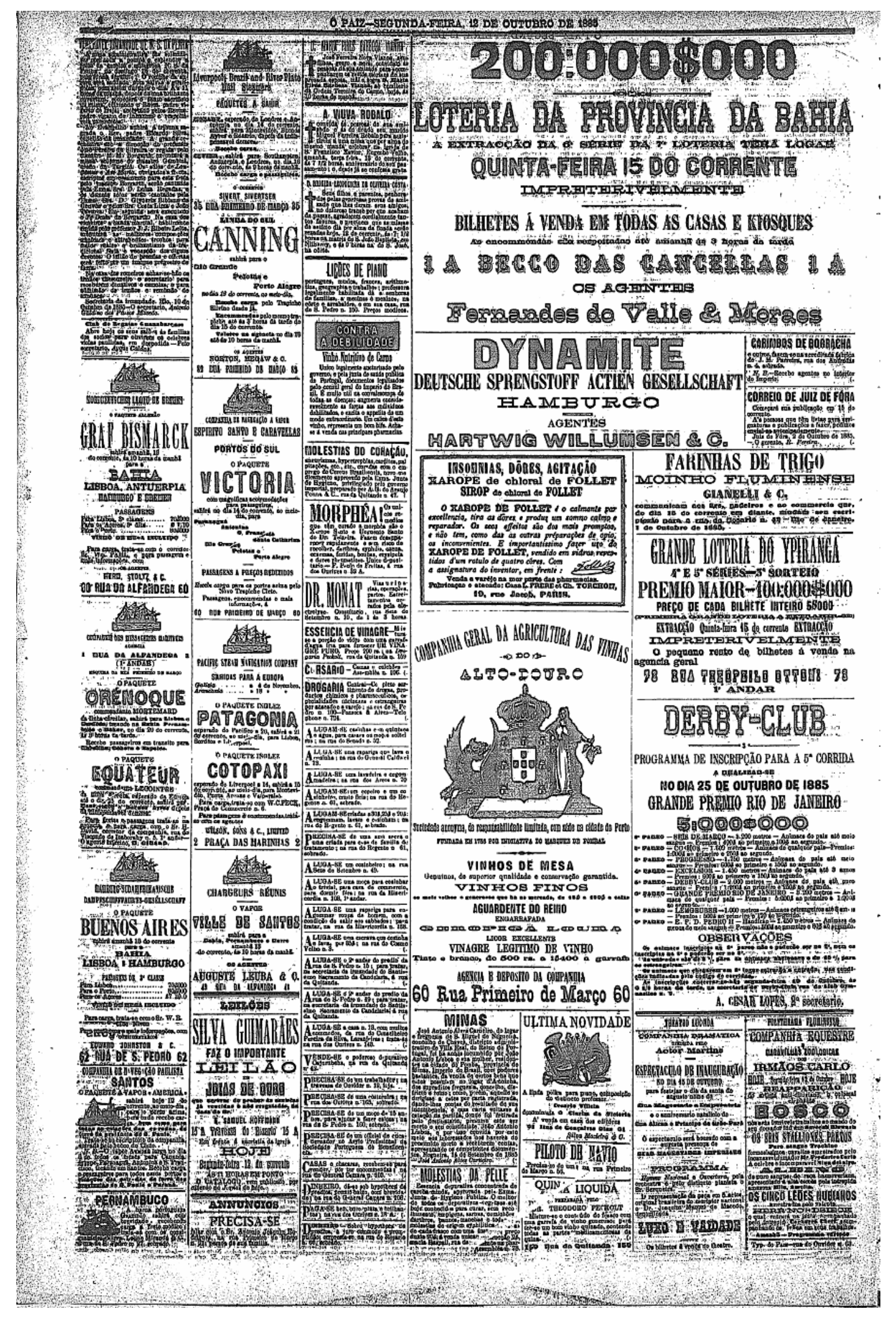

